Florida International University FIU Digital Commons

3-24-2009

\title{
Soviet and Western Bloc Competition in the Less Developed World and the Collapse of Détente
}

Douglas Rivero

Florida International University, driver05@fiu.edu

DOI: $10.25148 /$ etd.FI10022544

Follow this and additional works at: https://digitalcommons.fiu.edu/etd

\section{Recommended Citation}

Rivero, Douglas, "Soviet and Western Bloc Competition in the Less Developed World and the Collapse of Détente" (2009). FIU Electronic Theses and Dissertations. 213.

https://digitalcommons.fiu.edu/etd/213 


\section{FLORIDA INTERNATIONAL UNIVERSITY}

Miami, Florida

SOVIET AND WESTERN BLOC COMPETITION IN THE LESS DEVELOPED WORLD AND THE COLLAPSE OF DÉTENTE

A dissertation submitted in partial fulfillment of the

requirements for the degree of

DOCTOR OF PHILOSOPHY

in

POLITICAL SCIENCE

by

Douglas Rivero 
To: Dean Kenneth Furton

College of Arts and Sciences

This dissertation, written by Douglas Rivero, and entitled Soviet and Western Bloc Competition in the Less Developed World and the Collapse of Détente, having been approved in respect to style and intellectual content, is referred to you for judgment.

We have read this dissertation and recommend that it be approved.

Richard Tardanico

Dario Moreno

Richard Olson

David Gibbs

Ronald Cox, Major Professor

Date of Defense: March 24, 2009

The dissertation of Douglas Rivero is approved.

$\begin{array}{r}\begin{array}{r}\text { Dean Kenneth Furton } \\ \text { College of Arts and Sciences }\end{array} \\ \hline \begin{array}{r}\text { Dean George Walker } \\ \text { University Graduate School }\end{array}\end{array}$

Florida International University, 2009 


\section{DEDICATION}

I dedicate this dissertation to my fiancée and my mom. Without their

understanding, support, and most of all love, the completion of this work would not have been possible. I also dedicate this work to the people of the less developed world who have suffered terribly at the hands of U.S. and Western imperialism. 


\section{ACKNOWLEDGMENTS}

I would like to thank the Political Science Department at Florida International University. The financial support they provided, in addition to the vast intellectual knowledge, is greatly appreciated. I also wish to thank the members of my committee for their support and patience. Their strong and firm direction has been most treasured. I would especially like to thank my major professor, Dr. Ronald Cox, for his phenomenal guidance through this project. His direction and supervision has truly been priceless. Finally, I would like to thank my fiancée, Vanessa Castrogiovanni, for her wonderful support. A magnificent soul mate is what I needed to help me complete this demanding project! 


\title{
ABSTRACT OF THE DISSERTATION \\ SOVIET AND WESTERN BLOC COMPETITION IN THE LESS DEVELOPED WORLD AND THE COLLAPSE OF DÉTENTE
}

\author{
by \\ Douglas Rivero \\ Florida International University, 2009 \\ Miami, Florida \\ Professor Ronald Cox, Major Professor
}

The purpose of my dissertation was to examine the competition between the U.S.led Western bloc and the Soviet bloc in the less developed world during Détente. I assessed whether or not the Soviet bloc pushed for strategic gains in the less developed world in the middle-to-late 1970's and whether this contributed to the U.S. decision to abandon Détente in 1979. I made the attempt to test the international relations theory of balance of threat realism (Walt, 1992).

I accomplished the test in two ways. First, I measured the foreign aid allocations (military and economic) made by each respective bloc towards the Third World by using a quantitative approach. Second, I examined U.S. archives using the processtracing/historical method. The U.S. archives gave me the ability to evaluate how U.S. decision-makers and U.S. intelligence agencies interpreted the actions of the Soviet bloc. They also gave me the chance to examine the U.S. response as we evaluated the policies that were pushed by key U.S. decision-makers and intelligence agencies.

On the question of whether or not the Soviet bloc was aggressive, the quantitative evidence suggested that it was not. Instead, the evidence found the Western-bloc to have 
been more aggressive in the less developed world. The U.S. archives also showed Soviet actions to have been defensive. Key U.S. decision-makers and intelligence agencies attested to this. Finally, the archives show that U.S. officials pushed for aggressive actions against the Third World during the final years of Détente.

Thus, balance of threat realism produced an incorrect assessment that U.S. aggression in the late 1970's was a response to Soviet aggression during Détente. The evidence suggests structural Marxism and domestic politics can better explain U.S./Western actions. The aggressive foreign aid allocations of the West, coupled with evidence of U.S. decision-makers/agencies vehemently concerned about the long-term prospects of the West, strengthened structural Marxism. Domestic politics can also claim to explain the actions of U.S. decision-makers. I found extensive archival evidence of bureaucratic inter-agency conflict between the State Department and other intelligence agencies in areas of strategic concern to the U.S. 


\section{TABLE OF CONTENTS}

I. METHODOLOGICAL AND THEORETICAL INTRODUCTIONS 1 Introduction 1

Chapter Breakdown 2

Testing Methodology: Chapter by Chapter 3

$\begin{array}{ll}\text { The Theoretical Battle within the Chapters } & 6\end{array}$

Focusing on the Less Developed World 8

The West versus the Soviet Bloc? 10

Strategic Importance of Foreign Aid and the Dominance of Military Aid $\quad 10$

The Western and Soviet Blocs: The Strategic Alliances United 12

Through Military Aid

Economic Aid: The Other Strategic Tool 18

Process-Tracing and Historical Interpretation 20

Spheres of Influence 21

Theoretical Explanations of the Second Cold War (1972-1980) 23

Realism and the Fall of Détente 23

Structural Marxism and Détente (Core-Periphery Dynamics) 32

Domestic Politics and Détente $\quad 40$

Moving Forward 46

REFERENCES $\quad 50$

II. TRACING SOVIET GAINS IN THE LESS DEVELOPED WORLD 54

DURING DÉTENTE Introduction 54

Containing the Soviets and Controlling the Third World 54

Rebuilding Western Europe at the Expense of the Third World 54

Working with Europe to Encircle the Soviets Militarily 57

Using Foreign Aid to Control the Third World and Contain the Soviets 57

Section Conclusion $\quad 58$

The Tide Turns? $\quad 58$

The Effects of Détente $\quad 59$

Soviet Gains during Détente? 61

Soviet Involvement and the Competition for Allies in the Third World 61

Section Introduction $\quad 61$

$\begin{array}{ll}\text { Methodology } & 62\end{array}$

Asia 63

Section Introduction 63

Vietnam, Laos, and Cambodia 63

The China Split $\quad 64$

ASEAN $\quad 65$

Section Conclusion $\quad 66$

Middle East $\quad 67$ 
Section Introduction $\quad 67$

Soviet and Western Bloc Competition in the Middle East 68

The Horn of Africa $\quad 71$

Section Conclusion $\quad 73$

Southern Africa $\quad 73$

Section Introduction 73

U.S. and Soviet Competition in Angola 74

Mozambique $\quad 75$

Section Conclusion $\quad 76$

Latin America $\quad 77$

Section Introduction 77

The Soviets Lose Chile $\quad 78$

The Soviets Lose Peru $\quad 80$

Nicaragua $\quad 81$

Grenada $\quad 84$

Section Conclusion $\quad 85$

The Buffer Zone $\quad 85$

Section Conclusion $\quad 87$

$\begin{array}{ll}\text { Conclusion } & 87\end{array}$

Western Dominance Prevails $\quad 87$

Soviet Quantitative Gains and Losses during Détente 87

REFERENCES $\quad 91$

III. EXAMINING SOVIET AND WESTERN BLOC FOREIGN AID TO 95

THE LESS DEVELOPED WORLD

Introduction 95

Asia 96

Section Introduction $\quad 96$

The Sino-Soviet Split and Western Advantages in Military Aid in 97

Southeast Asia

Soviet defensiveness in Mongolia and the Economic Aid Advantages 99

of the U.S.

Section Conclusion 101

Middle East 102

Section Introduction 102

Western Aggression in Military and Economic Aid 103

Was Soviet Foreign Aid even Strategic? 105

Section Conclusion 107

Southern Africa 109

Section Introduction 109

Portuguese Imperialism Collapses $\quad 109$

Economic Aid to Southern Africa 110

Soviet and Western Bloc Military Aid to Strategic Areas of Southern Africa 112

Section Conclusion 113

Latin America 114 
Section Introduction $\quad 114$

Soviet Military Aid to Latin America 115

Soviet Foreign Aid to Central America/Caribbean 116

Was Cuba a Soviet Pawn? 119

After Somoza's Fall 120

The Emerging Split between the US and Western Europe 121

Section Conclusion 122

Buffer Zone 123

Section Introduction 123

Soviet and Western Bloc Military Aid to the Buffer Zone 125

Soviet and U.S. Economic Aid to the Buffer Zone 126

Section Conclusion 127

Eastern Europe 128

Section Introduction 128

Soviet Military Aid to Eastern Europe 129

Soviet Economic Aid to Eastern Europe 130

Section Conclusion 131

Conclusion 131

REFERENCES 144

IV. U.S. ARCHIVES AND THE SOVIET RESPONSE IN THE 146

THIRD WORLD DURING DÉTENTE
Introduction

The Bureaucratic Battle between Cyrus Vance and 148

Zbigniew Brzezinski

Section Introduction 148

Brzezinski and the Hard Line View 148

The Doves: Vance and the State Department 149

The Hawks Win 150

Probing Further into the Archives 151

Regional Analysis 152

Section Introduction 152

U.S. Archives and the Balance of Power in Asia 153

State Department's Analysis 154

Sino-Soviet Split Changes the Overall Balance of Power 154

U.S. Uses ASEAN to Strengthen its Balance of Power Position 155

Economic Power Trumps Military Power 156

Defense Department Analysis $\quad 157$

Section Introduction 157

Japan Becoming Vulnerable 157

Defense Department in the Minority and Overall Soviet Caution 159

U.S. Archives and the Balance of Power in the Middle East 160

Section Introduction $\quad 160$

U.S. Agencies and the Balance of Power in the Middle East 160

The Soviets in the Horn of Africa 162 
U.S. Archives and the Balance of Power in Sub-Saharan Africa 163

Section Introduction $\quad 163$

The NSC's Analysis of Angola before and after the MPLA Claims 165

Victory

State Department Analysis of Angola before and after the MPLA 166

Claims Victory

Cuba's Role in Sub-Saharan Africa (Cuban and Soviet Archives) 167

$\begin{array}{ll}\text { U.S. Archives on Cuban Independence } & 169\end{array}$

$\begin{array}{ll}\text { Section Conclusion } & 171\end{array}$

U.S. Archives and the Balance of Power in Latin America 172

$\begin{array}{ll}\text { Section Introduction } & 172\end{array}$

U.S. Agencies Agree that U.S. is to Blame 173

$\begin{array}{ll}\text { The Soviets and Nicaragua } & 175\end{array}$

$\begin{array}{ll}\text { The U.S. and Central America } & 177\end{array}$

$\begin{array}{lr}\text { Carter's Perspective } & 179\end{array}$

$\begin{array}{ll}\text { Section Conclusion } & 179\end{array}$

U.S. Archives and the Balance of Power in Afghanistan 180

$\begin{array}{ll}\text { Section Introduction } & 180\end{array}$

$\begin{array}{ll}\text { State Department View } & 180\end{array}$

State Department/U.S. Embassy Reports 181

Interagency memorandums Defer to State Department during Late $1979 \quad 184$

$\begin{array}{ll}\text { Soviet Documents and Afghanistan } & 185\end{array}$

$\begin{array}{ll}\text { Section Conclusion } & 187\end{array}$

$\begin{array}{ll}\text { Soviets on the Defensive in Eastern Europe } & 189\end{array}$

$\begin{array}{lr}\text { Section Introduction } & 189\end{array}$

$\begin{array}{ll}\text { Misjudging Human Rights } & 190\end{array}$

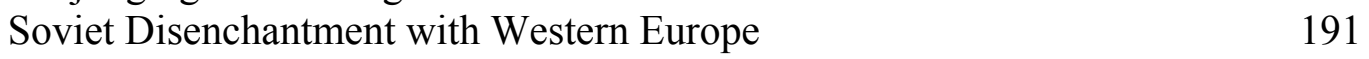

U.S. Economic Warfare $\quad 191$

$\begin{array}{ll}\text { Section Conclusion } & 192\end{array}$

Détente, the Third World, and Strategic Nuclear Arms 193

$\begin{array}{ll}\text { Section Introduction } & 193\end{array}$

$\begin{array}{ll}\text { The Third World } & 193\end{array}$

$\begin{array}{ll}\text { Strategic Arms } & 195\end{array}$

$\begin{array}{ll}\text { State Department View } & 195\end{array}$

Other Agencies (Mostly) Agree 197

$\begin{array}{ll}\text { Section Conclusion } & 199\end{array}$

$\begin{array}{ll}\text { Conclusion } & 200\end{array}$

$\begin{array}{ll}\text { REFERENCES } & 206\end{array}$

V. U.S ACHIVES AND THE U.S. RESPONSE TO THE SOVIET 211

THREAT IN THE THIRD WORLD

$\begin{array}{ll}\text { Introduction } & 211\end{array}$

Regional Analysis of U.S. Actions in the Third World during Détente 212

Regional Analysis of U.S. Actions in Asia 212 
$\begin{array}{ll}\text { Section Introduction } & 212\end{array}$

$\begin{array}{ll}\text { State Department } & 213\end{array}$

Defense Department $\quad 216$

$\begin{array}{ll}\text { Key Policymakers Agree } & 217\end{array}$

$\begin{array}{ll}\text { Section Conclusion } & 219\end{array}$

Regional Analysis of U.S. Actions in the Middle East 221

Section Introduction $\quad 221$

$\begin{array}{ll}\text { Soviet Actions } & 222\end{array}$

Kissinger and U.S. Actions $\quad 223$

$\begin{array}{ll}\text { U.S. Agency Cooperation } & 227\end{array}$

$\begin{array}{ll}\text { Section Conclusion } & 228\end{array}$

Regional Analysis of U.S. Actions in Southern Africa 229

Section Introduction $\quad 229$

State Department Fights for Diplomacy $\quad 230$

Kissinger's Power and U.S. Instigation 232

Cuban Archives show U.S. Aggression 234

State Department Officials Agree with Cuban Archives 235

Economic Interests? 236

$\begin{array}{ll}\text { Section Conclusion } & 237\end{array}$

Regional Analysis of U.S. Actions in Latin America 239

Section Introduction $\quad 239$

Liberalism Defeats Realism? 239

$\begin{array}{ll}\text { Failure to Change U.S. Policy } & 240\end{array}$

$\begin{array}{ll}\text { U.S. Clients Resist Change } & 241\end{array}$

Carter's Failure to Rein in U.S. Repressive Clients 242

Success in Panama 243

$\begin{array}{ll}\text { Section Conclusion } & 244\end{array}$

Regional Analysis of U.S. Actions in Afghanistan 245

Section Introduction $\quad 245$

$\begin{array}{ll}\text { The Bureaucratic Battle } & 245\end{array}$

Section Conclusion $\quad 249$

$\begin{array}{ll}\text { The Strategic Arms Race } & 250\end{array}$

U.S. Archives and the Deterioration of the Western Bloc during the 1970's 252

$\begin{array}{ll}\text { Section Introduction } & 252\end{array}$

U.S. Archives and the Cracking of the Western Alliance 254

Section Conclusion $\quad 259$

$\begin{array}{ll}\text { Conclusion } & 260\end{array}$

$\begin{array}{ll}\text { Section Introduction } & 260\end{array}$

$\begin{array}{ll}\text { Regional Findings Summary } & 261\end{array}$

Strategic Arms Summary 265

Reducing Soviet Gains? 266

U.S. Archives and the Interpretations of Structural Marxism, 266

Domestic Politics, and Balance of Threat Realism

REFERENCES 
$\begin{array}{lll}\text { VI. CONCLUSION } & 275\end{array}$

$\begin{array}{ll}\text { Introduction } & 275\end{array}$

$\begin{array}{ll}\text { Structural Marxism versus Domestic Politics } & 278\end{array}$

$\begin{array}{ll}\text { Seeking a Preponderance of Power } & 280\end{array}$

$\begin{array}{ll}\text { Section Introduction } & 280\end{array}$

The Imbalance of Power at the Start of the 1970's 282

Porter's Thesis and the Fall of Détente 284

Offensive Realism Fails as a Strategy 286

$\begin{array}{ll}\text { Blowbacks and U.S. Policy } & 287\end{array}$

$\begin{array}{ll}\text { Supporting Structural Marxism } & 291\end{array}$

REFERENCES 293

VITA

294 


\section{LIST OF TABLES}

TABLE

PAGE

1. Soviet Gains and Losses 90

2. Communist Bloc Military Aid to Indochina before and after 135 Sino-Soviet Split

3. Soviet and Western Bloc Military Aid to Indochina and ASEAN Spheres of Influence

4. Soviet Economic Aid to Mongolia

5. Soviet and U.S. Economic Aid to Asia

(Excluding Soviet Aid to Mongolia)

6. Soviet and Western Bloc Military Aid to Middle East

7. Soviet and U.S. Economic Aid to Middle East

8. Soviet and Western Bloc Military Aid to Strategic Areas of Middle East

9. Western Military Aid to Israel, Saudi Arabia, and Kuwait

10. Soviet Military Aid to Libya, Syria, and Egypt

11. Western Military Aid to Egypt

12. Soviet and Western Bloc Military Aid to Horn of Africa

13. Soviet and U.S. Economic Aid to Strategic Areas of Middle East

14. Soviet and Western Bloc Military Aid to Strategic Areas of Southern Africa

15. Soviet Economic Aid to Strategic Areas of Southern Africa

16. Soviet and U.S. Economic Aid to Sub-Saharan Africa

17. Soviet and Western Bloc Military Aid to Latin America 
18. Soviet and Western Bloc Military Aid to Strategic Areas of Latin America

19. Soviet and Western Bloc Military Aid to Strategic Areas of

Latin America (Excluding Cuban Aid to Angola)

20. Soviet Economic Aid to Cuba

21. Economic Aid to Nicaragua by Respective Countries/Agencies

22. Soviet and Western Bloc Military Aid to South America

23. Western Military Aid to South America

24. Soviet and Western/Chinese Military Aid to Afghanistan and Pakistan

25. Soviet and Western Bloc Military Aid to Buffer Zone

26. Soviet and Western Economic Aid to Buffer Zone

27. Soviet and U.S. Economic Aid to Afghanistan and Pakistan

28. Soviet Economic Aid to Afghanistan and Pakistan

29. Soviet Military Aid to Eastern Europe

30. Soviet Economic Aid to Eastern Europe 
Chapter I: Methodological and Theoretical Introductions

Introduction

My dissertation will examine the competition between the U.S.-led Western Bloc and the U.S.S.R.'s Soviet Bloc in the less developed world during the period of Détente (1972-1980). I shall assess whether or not the Soviet Bloc pushed for strategic gains in the less developed world in the middle-to-late 1970's and whether this contributed to the U.S. decision to abandon Détente in 1979. Citing revolutionary turmoil in such regions as Latin America, Asia, and Africa and increased Soviet military power during the 1970's, balance of threat realism argues that the U.S.S.R. began to provide significant military and economic aid towards traditional U.S./Western spheres of influence with the goal of weakening U.S. alliances. Since many U.S. academics and U.S. policymakers have viewed Soviet actions in this time period through the lenses of balance of threat realism, the purpose of this dissertation will be to test this theory of international relations.

Indeed, conventional academic wisdom as to what U.S. policymakers were thinking follows along Stephen Walt's realist balance of threat theory. The balance of power theory contends that, in a bipolar world, revolutions in the Third World provoke changes in the distribution of power, which inevitably brings a war for influence among the superpowers (Walt, 1992, p. 321). A loss of U.S.-led Western influence inevitably caused the U.S.S.R. to seek influence, which then forced the U.S. to prevent this from happening. Ultimately, as argued by U.S. policymakers during the Carter and the Reagan Administration, by improving its strategic military position and its conventional arms in the 1960 's, the Soviets positioned themselves to project force in areas of the world experiencing a collapse of political and power structures. As a result, the Soviet Bloc 
increased foreign aid (especially military) to the less developed world. Such moves, according to the Secretary of State at the time, Henry Kissinger, violated Détente. One of the most important goals of Détente, according to Kissinger, was to delineate each side's sphere of influence.

Being that it could be entirely possible that U.S. actions were simply a response to revolutions in the less developed world, and not Soviet actions, my dissertation will also test some alternative international relation theories. These theories include structural Marxism and domestic politics. In contrast to balance of threat theory, structural Marxism argues that the U.S. (West) was the real aggressive superpower during the 1970's. They suggest revolutions in the Third World and the imperatives of U.S. capital to dismantle such revolutions caused the U.S., not the Soviets, to be aggressive. Adherents of domestic politics do not go as far as supporters of structural Marxism. Those that study domestic politics suggest that specific interest groups and/or those with economic/strategic reasons for engaging in conflict in the less developed world were responsible for the aggressive actions of the U.S.

\section{Chapter Breakdown}

The main focus of chapter one will be to introduce the theories of balance of threat realism, structural Marxism, and domestic politics and explain how each theory would interpret the competition between the U.S. (Western Bloc) and the Soviets (Soviet Bloc) in the less developed world during the final years of Détente. However, before I proceed with a thorough review of each theory, I shall first elucidate the overall methodological approach of this dissertation. To begin with, I shall explain how each chapter proceeds in determining and testing whether or not the Soviets were aggressive 
during the middle-to-late 1970 's. However, I not only deploy different testing approaches to answer my main research question, I also use each chapter as an examination of both the conventional theory of international relations in this domain, balance of threat realism, and the alternative theories of structural Marxism and domestic politics.

Next, chapter one will move on to explaining some of my unique testing methodology. For instance, I begin by explaining why I compare the Western Bloc against the Soviet Bloc. To many academics, especially realists, comparing the Soviet Bloc to the West is simply heresy. They would suggest I compare the U.S. to the Soviets. However, for reasons I shall discuss below, my dissertation does link together the U.S., Japan, and some Western European to form the Western Bloc. The main reason for doing this is because these nations, the Western Bloc, possessed a profound interest in maintaining an anti-Soviet and anti-revolutionary world order. In fact, I go ahead and explain how foreign aid (specifically military aid) has bound the Western Bloc together. Foreign aid (economic and military) is, after all, one of the tools I use (in chapter three) to establish whether or not the Soviets (or the West) were aggressive during the middleto-late 1970 's. I then go ahead and explain my historical/process-tracing approach I use in chapters three, four, and five. Lastly, I explain why my dissertation compares U.S.Soviet (Western-Soviet) foreign aid and archival data through five different regions of the world.

Testing Methodology: Chapter by Chapter

My examination of U.S. (West) and Soviet (Soviet Bloc) competition in the less developed world during Détente begins with a historical analysis (chapter two) of such competition. From the post-World War II era to the end of the 1960's, I examine the great 
balance of power imbalance, both in strategic power and in the less developed world, between the U.S. and the Soviets. After all, the post-World War II era had left the U.S. as the most powerful state (a hyper-hegemon you can say) in the international system. I will also bring into focus the strategic importance of the less developed world to U.S./Western dominance in the international system. Finally, once I have placed into context the fact that the U.S. had overwhelming power over the Soviets and the less developed world prior to Détente, I shall use a historical analysis to assess the gains and losses in the less developed world of the U.S. (West) and the U.S.S.R. (Soviet Bloc) during the Détente time period.

To better (and truly) analyze my historical findings, however, I shall measure the foreign aid allocations (chapter three) made by each respective superpower Bloc towards the less developed world in a historical/process-tracing manner. More specifically, chapter three analyzes the foreign aid expenditures of both blocs towards the most strategic countries of each region, the timing of such foreign aid, the significance of each potential gain or loss, and other historical factors (most of which I already bring forward in chapter two) in my analysis of the final years of Détente.

Measuring the quantitative evidence in a process-tracing manner is extremely prudent. I cannot simply look at the aggregate foreign aid figures in my attempt to measure whether the Soviets were aggressive. This is because quantitative data on its own fails to explain the complete story. Cases of large foreign aid contributions to nonstrategic areas of the less developed world could also throw off the analysis. The timing component is also extremely important in this analysis. Discovering that one bloc increased foreign aid (especially military aid) during the same time its competitor was 
decreasing assistance will provide significant evidence as to whether the Soviet Bloc was attempting to reverse the balance of power.

The next step will be to evaluate whether top U.S. decision-makers and key U.S. intelligence agencies, such as the State Department, Defense Department, Central Intelligence Agency (CIA), and the National Security Council (NSC), believed that the Soviet Bloc made gains in the less developed world during the middle-to-late 1970's. As such, the archives of the Ford and Carter administration, which were in power during the last years of Détente, as well as national security archives, will be extremely important. Thus, chapter four will analyze how U.S. intelligence bureaucracies and key U.S. officials, such as Kissinger (Secretary of State under Ford), Cyrus Vance (Secretary of State under Carter), and Zbigniew Brzezinski (National Security Advisor under Carter) interpreted Soviet actions in the less developed world during Détente. Should U.S. archives not suffice, I may at times look at some Soviet archives to determine what top Soviet policy-makers were thinking. Overall, I shall analyze whether Soviet actions in the less developed world were aggressive or cautious.

Chapter five will then analyze the U.S. response and U.S. actions. Using U.S. archival material from U.S. intelligence agencies and the Carter/Ford administrations I shall explore which policies the U.S. pursued towards the Soviet Bloc and the less developed world during the 1970 's. Was the U.S. responding to the Soviet threat U.S. policymakers outlined in the previous chapter or simply revolutionary turmoil in the less developed world?

Once I have examined the archives I shall move towards the conclusion (chapter six). Chapter six will review all of the chapters and summarize my findings. It will also 
(hopefully) provide an answer towards my research question as I determine whether balance of threat realism or an alternative theory (structural Marxism or domestic politics) best explains U.S.-Soviet competition during the 1970's.

\section{The Theoretical Battle within the Chapters}

In my quest to determine which theory best explains U.S.-Soviet competition during the 1970's I shall use each chapter as an examination for the theories of balance of threat realism, structural Marxism, and domestic politics. Unfortunately, however, not every theory can be tested in every chapter. While each chapter can be used to test balance of threat realism and structural Marxism, domestic politics can only be tested in chapter four. Measuring and analyzing the foreign aid quantitative data, done in chapter three, does nothing to show whether or not there was any significant bureaucratic division within U.S. intelligence agencies.

For balance of threat realists, the examination of the foreign aid allocations (measuring them in a historical manner) of the Soviet Bloc and the West (in chapter three) should begin to show that the Soviets were becoming aggressive during this time period. They would then expect the intelligence and presidential archives (from Ford and Carter) to confirm these findings. Chapters four and five should show U.S. policymakers arguing that Soviet pressure against the balance of power was foremost reason for the U.S. abandonment of Détente (chapter four) and for the subsequent aggression actions on the part of the U.S. (chapter five).

On the other hand, structural Marxists would hypothesize that Soviet foreign aid, especially military, to traditional U.S. and Western spheres of influence was limited (less aggressive) and that there were no significant strategic Soviet attempt to outdo the 
U.S./West in foreign aid allocations to the less developed world (chapter three). After all, structural Marxists have long argued that the U.S. cynically used the Soviet threat to advance and promote U.S. economic policies, especially in light of increased capitalist competition from other core states (the West itself). For structural Marxists, the internal class politics of the less developed world during the 1970s, reflected by rising revolutionary mobilization, are more significant than the Soviet threat in predicting the U.S. response. For these reasons, they would expect U.S. foreign aid to be the most aggressive. In addition, structural Marxists would argue that U.S. archives (chapter four and five) should show that U.S. policymakers were more concerned with the structural economic consequences of political upheaval in the less developed world and rising Western competition, independent of Soviet influence.

Another possible explanation for the abandonment of Détente, irrespective of Soviet gains or aggressiveness, is the domestic politics approach. The domestic politics approach argues that the political divisions among U.S. domestic constituencies, from interest groups to capitalists themselves, battled for policy influence within the U.S. bureaucracy. In effect, because Third World activity went against the political, interestgroup, and economic interests of these powerful "coalitions", the U.S. abandoned Détente. Therefore, domestic politics would ask me to focus on the archives in chapters four and five. They would predict that I should find little evidence that U.S. policymakers were responding to Soviet gains in the balance of power during the 1970s. Instead, they would expect me to find that business conflict and bureaucratic competition better explain the timing of the U.S. abandonment of Détente. 
The result of this breakdown is that certain theories will be compared to each other in different chapters. Chapter three, my historical analysis of foreign aid data, will find me comparing balance of threat realism to structural Marxism. Chapter three is actually perfect for comparison since each theory has completely different predictions as to what I should find. The balance of threat realists would suggest the Soviets were aggressive while the structural Marxists would suggest the West was aggressive. Chapters four and five, however, will give me the ability to analyze each of the theories. The archival evidence will finally allow me to examine domestic politics and whether there were any significant divisions within U.S. intelligence agencies. However, they will also allow me to further test balance of threat realism and structural Marxism. The U.S. archives could show that U.S. policymakers were seriously concerned with Soviet gains (chapter four) and responded accordingly (chapter five). They could also show that the U.S. did not believe the Soviets were aggressive (chapter four) and that the U.S. response revolved more around its economic interests (chapter five).

\section{Focusing on the Less Developed World}

Thus far, as you can see from the three competing theories, the underlying premise of my dissertation is that the main explanation and reason for the collapse of Détente lies somewhere in the realm of Third World activity. Whether caused by Soviet gains, economic interests, or bureaucratic conflict, Détente's collapse is centered on the Third World. However there are some who seriously question the primacy of the lesserdeveloped world's impact in bringing down Détente. In fact, asymmetrical realists (as opposed to symmetrical balance of threat realists) argue that the competition in the buildup of strategic nuclear weapons was significantly more important in bringing down 
Détente than competition in the Third World. If asymmetrical realists are correct, then I should find evidence in the archives that U.S. policymakers were more concerned about the Soviet strategic gains in nuclear weapons and much less concerned about the Third World.

Even if strategic calculations were far more important in the U.S. decision to abandon Détente, third world revolutionary turmoil certainly played a key role. Should the archives in chapter four (which should give me a better understanding of why the U.S. abandoned Détente) negate the centrality of third world revolutions and/or Soviet involvement there in bringing down Détente, it is imperative to understand which school of thought complimented the arguments made by realists who focus on the nuclear arms race as the determining factor in bringing down Détente. After all, the conventional arms increases of the Soviet Bloc and the possibility of increased support for revolutionary anti-U.S. regimes certainly weighed heavily on the minds of U.S. policymakers during the late 1970's. So even if strategic nuclear weapons was most paramount in bringing down Détente, was it Soviet involvement in the less developed world, U.S. economic interests, or bureaucratic conflict that worked in combination with this strategic arms argument to bring down Détente?

In fact, although different theorists place the emphasis for the U.S. decision to abandon Détente on a range of different factors, all accounts of Détente's collapse have to consider the relative weight of Third World competition between the U.S. and the Soviets as a potentially decisive factor when it comes to Détente's collapse. To understand the increased U.S. militant fervor that developed in the late 1970's and early 1980's, culminating in the election of hardliner Ronald Reagan (US conservatives very 
concerned over Iran and Nicaragua), it is paramount that I pay significant attention to the dynamics occurring in the Third World. Starting in Indochina and the Middle East, moving to the African states of Ethiopia, Somalia, and Angola, and finally shifting to the U.S. strategic zone of Central America, the superpower alliances engaged in many protracted proxy wars just before and after Détente's collapse in the late 1970's. Once it is recognized that the less developed countries in these regions were ripe with strategic natural and economic resources, which each superpower wished to control for itself and/or deny to the other, then it becomes extremely important that I study the less developed world's impact on Soviet-American relations during the late 1970's. The West versus the Soviet Bloc?

In this section, however, I explain why I treat the U.S.-led Western Bloc and the U.S.S.R.'s Soviet Bloc as united entities. With the help of military aid, Western political elites worked together to promote an anti-Soviet and anti-revolutionary world order. Geostrategic and economic considerations simply dictated this. For these reasons, I shall compare the military aid allocations (in chapter three) of the West and the Soviet Blocs. I will now also explain the importance of measuring the economic aid allocations of the U.S. and the U.S.S.R. towards the less developed world. Although important for alliance consolidation, I argue that economic aid is strategically inferior to military aid. Before doing that, however, I shall explain why foreign aid (especially military aid) is an important tool in consolidating and expanding alliances in the less developed world. Strategic Importance of Foreign Aid and the Dominance of Military Aid

Foreign aid is nothing more than a strategic tool used to gain allies and thus political and economic advantages in the less developed world. However, as argued by 
Hans Morgenthau (1962), military aid is the most strategic type of foreign aid (in comparison with economic aid) since it is immensely useful in buttressing alliances and thus protecting military and economic interests in the less developed world (p.303 ). He cites that military aid has traditionally encompassed the "lion's share" (besides a brief period in the early 1960 's) of U.S. foreign aid programs, especially since the onset of the Cold War, thus verifying the superiority of military to economic aid (Morgenthau, 1962, p. 302). Moreover, as evidenced by the rise of Great Britain in the $17^{\text {th }}$ and $18^{\text {th }}$ centuries, large increases in military aid towards strategic countries in the less developed world is very much correlated with a country's intent to alter the balance of power in their favor in order to make strategic and economic gains (that would further improve their military power). Looking through the treaties between Great Britain and its allies, Morgenthau (1962) was "struck by the meticulous precision by which obligations to furnish troops, equipment, logistical support, food, money, and the like" correlated according to the strategic importance of the recipient nation (p. 302).

Although less significant than military aid, I shall also compare the economic aid allocations of the U.S. and the U.S.S.R. In fact, Morgenthau recognizes that economic aid is a very useful tool in helping to buttress and consolidate existing allies and/or emerging allies in the less developed world. Indeed, economic assistance is nothing more than bribery (according to realists) used by the donor country as they try to gain military and economic advantages in the less developed world. The stronger country simply buys out the loyalty and allegiance of the local regime in the weaker country. Local leaders from the weaker country benefit from some of the spoils of exploitation in exchange for their 
subservience and the exploitation of their countries (to the benefit of the stronger country).

However, within the pecking order of foreign aid assistance, Morgenthau and many realists believe that military aid is a much more significant and strategic type of foreign aid. Without military power as a backup, exploitative economic aid allocations (and thus exploitative economic relationships that enhance military power) to the benefit of the donor country would simply never occur. Far from benefiting from the infusion of capital, economic aid has never aided in the economic development of any country in the less developed world. Instead, U.S. aid packages "have helped create major markets for agricultural goods and industrial exports" for the donor country (Mittal, 2006, "U.S. Foreign Assistance": Section: “A Murky Past”, para. 5). The reason for this is that "USAID (the agency responsible for allocating economic aid) follows and implements the Buy American Act, which requires that American money aid and grants be used to purchase goods and services which are U.S. produced and U.S. delivered" (Mittal, 2006, "U.S. Foreign Assistance": Section: "A Murky Past", para. 5). According to the "USAID Agency Performance Report" that Mittal (2006) cites that " $71.6 \%$ of bilateral aid commitments were tied to the purchase of U.S. goods and services" ("U.S. Foreign Assistance”: Section: “A Murky Past”, para. 5).

The Western and Soviet Blocs: The Strategic Alliances United Through Military Aid

When analyzing the balance of power in international relations most scholars simply begin by looking at how many superpowers exist (whether the world is unipolar, bipolar, or multipolar). Such an analysis has often led to studying the Cold War in terms of assessing the strategic interactions between the U.S. and the U.S.S.R. while completely 
negating the alliance partners of these two allies. The countries of Eastern Europe (Warsaw Pact) and the West were not only an integral part of the Cold War, but the alliance schemes they developed with the two respective superpowers exhibited longevity and significant military integration that have led certain analysts to "regard them as different from pre-WWII alliance schemes" (Rothgeb, 1981, p. 493). John Herz (1980) has argued that the "Soviet Union makes more concessions to its allies than often is acknowledged, and that the U.S. dominates its allies [Suez Canal 1956] more than the loose model implies" (p. 495). Renowned realist Morgenthau (1993) has also pointed out that while "pre-WWII alliances were usually unions of near equals, the [newly evolving] blocs essentially consist of a clustering of smaller states around a superpower," suggesting that NATO has been dominated by the U.S. (p. 494). Overall, these authors argue that the new NATO and Warsaw Blocs were far more integrated and vertically organized than any other historical blocs thanks to the dominant political and economic power of Washington and Moscow within these blocs.

The main critique that comes from comparing the Soviet Bloc to the West suggests that it is foolish to lump the Western countries together since they were not as politically, ideologically, and militarily dominated by the U.S. Thus, it is suggested that the U.S.S.R. had much more control over the Soviet Bloc that simply did not allow any schisms on foreign policy matters. Many liberal scholars simply believe the U.S. used its superpower in a benign manner in regards to its Western allies, while the U.S.S.R. was the perennial bully. Traditional realism would scoff at analyzing NATO and the Warsaw Pact as separate and competing blocs as they would suggest that the U.S. simply could not be certain and confident that its NATO allies would not defect and or form their own 
rival union (U.S. could not trust its Western allies in an anarchic world). In their view, any comparison of the Cold War must revolve around the U.S. and the U.S.S.R. These views have led to a biased study of the Cold War since many scholars go as far as compare the U.S. and the entire Soviet Bloc (since the Soviets dominated these countries in their view) without any mention of the rest of NATO and the other members of the G7.

However, when it comes to the military aid arena (the most significant and strategic type of foreign aid (as it can seriously affect the balance of power), which I analyze through the U.S. Disarmament Agency's (USDA) own World Military Expenditures and Arms Transfers (WMEAT), there is research that shows consistent parallels between U.S. and G7 military aid expenditures. As shown by John Oneal's (1990) Testing the Theory of Collective Action: NATO Defense Burdens 1950-1984, "the greater the perception of the Soviet threat was, the greater the demand for collective security, and the greater the contribution of the allies to the alliance" (p. 433). Analyzing the problem discovered by Mancur Olson (1971), in The Logic of Collective Action, describing how small states free ride on the defense expenditures of the larger alliance partners (in this case Western Europe on the U.S.), the U.S. could expect larger donations of military aid from its "free riding" Western partners whenever the Soviet threat seemed to increase, thus demonstrating parallel security interests (p. 15).

The West was also united against the less developed world. While some critics would argue that Western nations pulled back from direct third world intervention during the 1960's and 1970's (such as in Vietnam and Angola), it is important to take into consideration the indirect support given by the Western nations to the U.S. when it came to crushing national liberation movements. In fact, France and Britain vetoed sanctions 
against apartheid South Africa and provided significant aid to the pro-Western Mobutu in Zaire in the face of the "Angola" threat to Southern Africa. Western European nations also significantly increased military aid allocations towards pro-Western Southeast Asian regimes during the same time period as well (USDA, 1975-1979, pp. 128-131). Thus, it is apparent that the strategic interests of the U.S. and Europe were defended together. One notable exception was Latin America during the 1980s, when the U.S. could not count on the same level of support (especially South America).

Comparing the Western and Soviet Blocs (albeit in strategic military terms), does have credibility within realism thanks to both Stephen Krasner (1985) and Jeffrey Hart (1983). Their understanding of realist political economy not only put a dent on dependency and Marxist theories of exploitation, but they also helped to weaken traditional concepts of realism by showing how the U.S. and the G7 have common strategic interests (mostly defended with military aid) against the less developed world. Krasner's (1985) Structural Conflict: The Third World Against Global Liberalism points out that the less developed world pushed for a New International Economic Order in 1974 that among other things would call for the West to renegotiate Third World debt, provide industrial technology on more favorable terms, recognize the right to expropriation of foreign direct investment, provide greater control of MNC's and the repatriation of money, establish preferences for Third World products coupled with the removal of Northern trade barriers, and establish Northern support for new commodity agreements (p. 3).

Thus, according to realist political economy, the Third World was promoting a new mercantilist power structure (the same the West has used against them) in seeking to 
move towards the First World. Krasner (1985) points out that the multilateral character of the Third World's call for change can be understood since the less developed world can only put pressure on the North by uniting since in division they can only extract bilateral agreements that force each country to "race to the bottom" and thus they all continue to be exploited (p. 4). This call for the First World to change its foreign economic policies against the less developed not only demonstrates that the less developed world believes that the First World has practiced mercantilism but it also shows that they were seeking to use mercantilism themselves as they abandoned some of the calls of dependency theorists to pull from the world capitalist system. Thus the Third World also viewed the First World as a mostly united entity. However, the goals of nationalists in the less developed world failed because of the total lack of consistent collaboration. The free rider problem and the self-interest of individual nations were ultimately significant roadblocks for leaders in the less developed world to overcome.

The response to the less developed world's call for a New International Economic Order by the G7, which was very negative, demonstrates how much consensus and unification there was by the West in its foreign policies. Despite left-leaning governments within the G7, none were willing to back the Third World's bid to reverse the international economic order. Division and partial support for the less developed world was only found in Sweden, the Netherlands, and Norway. Hart's (1983) explanation for Swedish, Dutch, and Norwegian support is that small economies are better able to adapt to any changes in the international economy, especially when they can "free ride" on the hostility that they knew would come from the rest of the G7 (p. 46). Most importantly, it 
is obvious these countries have much less access and rely much less on the raw materials of the less developed world.

In fact, a wide range of scholars from Helleiner (1996) and Harvey (2005) to Stiglitz (2003) are just a few who have shown that Third World revolutions that have threatened the Western backed international political order have always been condemned and punished by the G7. The Western countries neither break ranks to join the less developed world nor do they question their fundamentally hypocritical economic policies (pushing for the less developed countries to open up their borders for trade while keeping their own border closed) imposed on the less developed world. Further, as shown by David Calleo's (1996) "Restarting the Marxist Clock", one of the main reasons for Western unity during the Cold War and Détente, was the Soviet Union. Its call for a socialist economic order, which had much appeal in the less developed world, had managed to wedge the capitalist West even closer than before (p. 2). Thus, the West has been a very united Bloc.

For these reasons, I shall consider all G7 military aid as simply Western military aid that sought to keep the status quo (non-revolutionary) political and economic order in place. As mentioned above, military aid is the primary weapon through which the West maintained a political and economic order that brought most of the benefits of the global economy towards the advanced industrial economies. In fact, the U.S. and the West, as will be shown in Chapter two, possessed significant interests in maintaining a world order that was both anti-Soviet and anti-revolutionary. Thus, military aid allocated by the West (the G7) will be considered an instrumental policy tool in preserving the national interests (non-revolutionary/anti-Soviet political order) of the West while military aid from the 
Soviet Bloc will be considered an instrumental policy tool in preserving and expanding the national interests of the Soviet Bloc. These military aid deliveries (from both blocs) will be combed from the U.S.'s own Disarmament Agency, which publishes allocations of military aid in its annual WMEAT report.

Economic Aid: The Other Strategic Tool

According to the realist perspective articulated by Morgenthau (1962), economic aid is an important policy tool used to buttress and consolidate alliances in the less developed world (304). Such aid allocations involved geostrategic considerations. Indeed, according to Quintin Bach (2003), the majority of Soviet economic assistance to the less developed world was funneled towards such Cold War strategic areas as Eastern Europe, Mongolia, Cuba, and Vietnam (Appendix VI). The U.S.'s economic assistance, on the other hand, was usually predominant in such strategic regions of the world as Latin America, the Middle East/Buffer Zone, and Asia (OECD). Ultimately, considering the predominance of American economic power following WWII, there should be no surprise that U.S. economic assistance was far more spread out than that of the Soviet Union. I will show this to be the case in Chapter two.

Economic aid, however, ranks as inferior to military aid when it comes to altering the balance of power. Tanks, bombers, ships, troops, training, guns, and other types of military hardware are what it takes to protect allies and to help topple unfriendly regimes. Economic aid is also an inferior tool compared with military aid considering I cannot truly compare the Soviet Bloc and the West as united entities using economic aid allocations. I can only compare the economic allocations of the U.S. and the U.S.S.R. 
In fact, though some could suggest that I should go on and include G7 and Warsaw Pact economic aid to the less developed world when analyzing foreign to the less developed world, my project rejects this position on the grounds that it fails to consider that the U.S. and the rest of the G7 members, though working together to prevent revolutionary movements from taking power and helping to maintain an unequal exchange political order (as well as maintain an anti-Soviet system), used economic aid packages to make slight gains at the expense of some other G7 countries. That is, it is possible that economic aid packages were used by $\mathrm{G} 7$ members to increase the gains they received from the unequal economic order, while lessening the gains received by other members of the $\mathrm{G} 7$.

It is important to consider that there have been some important differences in U.S. and European economic policy, both towards each and toward the less developed world. Examples of fissures between G7 states includes the case of the U.S. and Belgium in Zaire, the U.S., France, and Britain in regards to the Suez Canal Crises, and slightly less exploitive economic agreements between Canada and the less developed world (to gain at the expense of the U.S.). Moreover, I also find that the U.S. and Great Britain pushed for the EuroMarket and the elimination of the Bretton Woods system in the 1970's, which is serious evidence of economic competition and policy fissures between the U.S./UK and its G7 partners (Helleiner, 1996, p. 3). While Japan (at first) and other G7 countries resisted the elimination of important capital and currency controls and other government regulation on national market systems, the U.S. push was driven by American fears of European superiority in productive capitalism. Therefore, although the U.S. and European states firmly sought to dominate the less developed world and to counter Soviet 
power (obviously making the military aid arena between both highly parallel), they had important economic policy battles and incongruence in the less developed world, which would be most readily apparent in the economic aid arena.

Nevertheless, in figuring out whether Soviet economic aid was aggressive and seeking to steal away a certain sphere of influence away from the U.S. I shall analyze the foreign aid allocations sent by the U.S. and the U.S.S.R. to the most strategically important countries in the specific region, the timing of such aid, and other historical factors. It is important to consider whether such economic aid allocations were expended towards non-traditional recipients in the less developed world. Such a finding would highlight an increased desire by the donor nation to consolidate control over more countries in the less developed world. Overall, Soviet economic data comes from Bach's (2003) Soviet Aid to the Third World while U.S. economic data comes from the OECD's (1971-present) Stat Extracts: Development Aid. Process-Tracing and Historical Interpretation

My dissertation also used the historical/process-tracing approach in chapters three, four, and five. Since timing would be very important in understanding U.S./Western foreign aid allocations during the 1970's was a direct response to aggressive foreign aid allocations made by the Soviet Bloc, Chapter three goes ahead and measures the foreign aid allocations in a historical manner. Chapter three also analyzes the strategic value of the nation receiving foreign assistance from the Soviet Bloc. Analyzing the strategic importance of the recipient state is extremely important since large foreign aid allocations to non-strategic states could throw off my analysis regarding whether or not the Soviets were seeking to overturn the balance of power. 
Chapters four and five have me introducing the process-tracing approach. Besides analyzing the documents in a historical manner, I use the process-tracing approach as it uses "evidence about various features of the decision-making environment, including both the actor's definitions of their situation and the institutional arrangements affecting their attention, information-processing and behavior" as an interpretive tool for analysis (Fordham, 1997, p. Section: “The Important of Process", para. 2). Using the process-tracing approach, I shall interpret the decisions of top U.S. policymakers in order to determine whether there was a single cohesive balance of power policy view, as suggested by realism, being articulated. If not, then I shall study whether economic motives and/or significant bureaucratic and political divisions (domestic politics) were evident within the U.S. foreign policy apparatus.

Bringing in specific international relations theories (such as balance of threat realism, structural Marxism, and domestic politics) will give me a solid framework for measuring the political analysis and political decision-making of U.S. policymakers and U.S. intelligence agencies. It will give me a solid foundation for understanding how these actors viewed the international environment. Adherents of process-tracing strongly believe this method is reliable and scientific. Unlike my historical analysis in chapter two, which is much weaker considering it only looks at events in timeline fashion (and can thus be questioned by some as a cherry-picked bias account), my historical/processtracing method goes much deeper.

\section{Spheres of Influence}

To test whether the Soviet Bloc made gains during Détente and/or sought to reverse the balance of power, I shall break the world up according to spheres of 
influence. During the Cold War there was acknowledgement that Western Europe was a U.S. sphere of influence while Eastern Europe was a Soviet sphere of influence. Latin America, Asia, and Africa were also considered to be under the U.S.-led Western sphere of influence while Mongolia, Afghanistan, and parts of Central Asia were classified under the Soviet sphere. While many scholars have done this in the past, the main difference in this study revolves around separating Northern Africa from Africa and uniting it with the Middle East while also taking Iran and Iraq away from the Middle East and uniting it with Pakistan, India, and Afghanistan (since the U.S. claims the Soviets were trying to advance in this region and eventually encroach on the Middle East) to form the traditional buffer zone. Other spheres such as Latin America and Asia will follow along traditional lines.

The unification of Northern Africa and the Middle East revolves around the fact that Northern Africa simply has more in common, geostrategically, with the Middle East than with Africa. Oil transportation along the Mediterranean and the Red Sea, its proximity to Western Europe, (the Western bridgehead in the Middle East), and their animosity and proximity to Israel make Northern Africa quite different from the dynamics involved with the rest of Africa. Sub-Saharan Africa is mostly characterized as a strategic area for minerals and raw materials. Although there is oil in Africa, its quantities were not considered at the time to be even close to that of the rest of the Middle East, and sub-Saharan Africa is simply not within most of the vital oil transportation routes. Culturally speaking, Northern Africa is also much closer to the Middle East (mostly Arab and hostile towards Israel) while the rest of Africa is characterized by many indigenous ethnic tribes with many local rivalries as well. 
As far as the traditional Buffer Zone is concerned, it should be treated as a region of its own due to the fact that it is located precisely between the Soviet Union and the Middle East (an area of Western superiority). Both the West and the U.S.S.R. had vital and strategic interests (the U.S.S.R. in a defensive manner and in regards to the Caspian Sea) and the West in terms of the strategic Middle East. Many analysts, however, have placed certain buffer states within certain Cold War blocs, such as Afghanistan within the Soviet camp and Pakistan within the West. Prior to the initiation of Détente, they also state that Iran was a Western backed state while Iraq was a Soviet backed state.

Theoretical Explanations of the Second Cold War (1972-1980)

Now that I have explained my chapter by chapter approach and my testing methodologies, it is time to introduce how each theory analyzes Soviet and Western Bloc competition in the less developed world during Détente. My literature review will serve as an important background towards my analysis and conclusion relating to which theory best explains the foreign aid and archival data findings.

\section{Realism and the Fall of Détente}

Realizing that the hegemonic costs to providing global security had eroded U.S. economic power and prestige (and thus weakening the Western Alliance) in the early 1970's, U.S. foreign policy guru and National Security Advisor to President Nixon, Henry Kissinger, sought a new method of containing the Soviet Union at lower costs. Kissinger argued that the Cold War strategy of containment had failed since the U.S.S.R. still achieved nuclear parity, European allies such as West Germany were clamoring for better relations with the East, and the U.S. was failing in its mission to contain the U.S.S.R. in Southeast Asia (Cox, 1990, pp. 32-33). Recognizing the implications of the 
Sino-Soviet split and the fact that the U.S.S.R. had severe economic problems, Kissinger pushed for negotiations. As a result, the U.S. moved ahead with tactical nuclear arms agreements and an overall agreement stated that each superpower would be left alone to manage their respective spheres of influence. It was believed this strategy would help stabilize the Vietnamese South and integrate the U.S.S.R. into the world market. Most importantly, U.S. policymakers believed this strategy would curtail Soviet "adventurism" in the less developed world and help shift U.S. attention to more significant areas of the world.

Détente collapsed between 1979 and 1980 and was followed in the early 1980's by the Reagan Doctrine. The Reagan Doctrine argued that Détente had not prevented the U.S.S.R. from trying to alter the balance of power, both conventional and nuclear. The critics of Détente behind the new doctrine blasted the original signing of SALT I. They believed Détente was flawed in favor of the Soviets since the U.S. was only possessed 1,064 ICBMs (intercontinental ballistic missiles) while the Soviets possessed 1,618 ICBMs (Woolf, Section: "The Interim Agreement on Offensive Arms", para. 1). Détente critics believed this gave the Soviets an advantage in the strategic arms race. These critics also attacked a protocol to the treaty stating that "the U.S could deploy up to 710 SLBM [sub-marine launched ballistic missiles] launchers on 44 submarines, and the Soviet Union could deploy up to 950 SLBM launchers on 62 submarines" (Woolf et al, Section: "The Interim Agreement on Offensive Arms", para. 1). They believed this further widened the strategic divide.

Incoming President Ronald Reagan and the alternative Team B within the CIA also believed the Soviets were becoming too aggressive with their military expenditures. 
Team B, which included such prominent conservatives as Donald Rumsfeld, Paul Wolfowitz, and Richard Perle, suggested the Soviet nuclear arsenal war far more advanced (both qualitatively and quantitatively) than previous CIA estimates (Kahn, 1998, p. 3). In addition, according to Roger Kanet (1992), in Soviet Foreign Policy and East-West Relations, instead of ceding to the limitations imposed by the SALT I and Vladiovostok Agreements, the Soviets increased production of intercontinental ballistic missiles (p. 68). He argues the Soviets were manufacturing larger amounts of military equipment than the U.S. by the start of the 1970's. Most significantly, he suggests the introduction of intermediate SS-20 missiles (which were specifically targeted on Western Europe) significantly tilted the balance of forces more towards the direction of the Soviet Union. Though Kissinger suggested the U.S. still had an advantage with offensive military power, critics accused U.S. policymakers of weakening defensive capabilities.

As far as the less developed world goes, balance of threat realists further highlight that there were declines in U.S. defense spending every year during the early 1970's. In fact, U.S. Senate Budget Committee figures show that U.S. military expenditures during the Nixon and Ford administrations decreased military spending by "nearly a third from its peak during the [Vietnam] war" (Finley, 2003, para. 2). Such a decline sent the wrong signal, according to balance of threat realists, to US enemies around the world.

The result, according to U.S. hawks/realists, was that the U.S.S.R. continued to build up its conventional military force with significant economic investments in military hardware. Francis Sempa (2004) certainly believes this was the case and agreed with the U.S. decision to engage in aggressive actions against the Soviets. In his view, "acquiescence to the loss of strategic nuclear superiority, a willingness to overlook Soviet 
cheating on arms control agreements, and the U.S. abandonment of longtime allies in Southeast Asia" was only the beginning (Sempa, 2004, para. 7). The result was US aggressive actions. As Ronald Reagan stated in January 1983 (with National Security Decision Directive 75):

U.S. policy was "[t]o contain and over time reverse Soviet expansionism..., $[\mathrm{t}] \mathrm{o}$ promote...the process of change in the Soviet Union toward a more pluralistic political and economic system..., [to] exploit...vulnerabilities within the Soviet empire" in an effort to "loosen Moscow's hold" on Eastern Europe. (Sempa, 2004, para. 8)

Far from freezing the balance of power in the military realm, realists contend that Détente only tied the hands of the U.S., threatening the prestige and leadership of the U.S. in relation to its Western allies. Neil McFarlane (1983), a prominent realist, argues in Soviet Intervention and Third World Conflicts, that the "failure of American deterrence was the critical permissive condition of Soviet intervention" (p. 17) in the less developed world during the late 1970's. Because the risk of American involvement had diminished with Détente (and the Vietnam syndrome), the U.S.S.R. decided to pursue "cautious opportunism" in Angola, Ethiopia, Afghanistan, and other significant Third World countries. The bottom line to realists, such as R.J Rummel (1976), is that “cooperation does not bring peace, nor does restraining one's own power, because power must be backed up by military force" (p. 3). Instead of tying its hands down with arms treaties and slashing military spending, the U.S. should not have sought to "freeze" the balance of power, but should have matched and exceeded Soviet gains in the military sphere. As they see it, a relative decrease in U.S. military power (as the dominant leader of the West), combined with revolutionary turmoil, catapulted the U.S.S.R. into U.S. and Western spheres of influence. 
Revolutionary turmoil, and thus Soviet interference, was further enhanced by the withdrawal of support for U.S. backed authoritarian regimes in Nicaragua (where President Carter terminated military aid and cut economic aid), and Iran (where President Carter drastically cut military aid). Thus, these were crucial mistakes made during the period of Détente, according to realists. U.S. restraint tilted the balance of forces in these countries allowing revolutions to emerge that challenged U.S. strategic interests. After all, the "insurrectionist movements [that] gained strength and achieved resounding victories in Asia, Latin America, and Africa favored the Soviet Union in the balance of forces" (Dixon et al, 1983, page 4), regardless of Soviet complicity in aiding these movements. The failure of such Western countries as Portugal in crushing national liberation movements in Africa also provided further power vacuums for the Soviet Bloc to take advantage of.

For balance of threat realists, appeasement through arms control treaties, military aid cutbacks to Third World allies, and "reductions" in the rate of U.S. military spending meant the Soviets smelled "blood". Thus, the U.S.S.R. intervened in the less developed world's revolutionary turmoil (in the most strategic countries) and altered the balance of power between 1975 and 1981 with foreign aid packages and increased strategic partnerships (Lagon, 1992, p. 44). Indeed, Lagon (1992) argues that increased foreign aid to Afghanistan, Angola, Cambodia, Nicaragua, Ethiopia, Laos, Mozambique, Grenada, and South Yemen prove that the U.S.S.R. was seeking to alter the balance of forces to gain influence in the Third World.

In fact, pointing to the rise of Marxist-Leninist regimes in Nicaragua and Angola, realism suggests that the Soviets had interfered in U.S. and Western affairs by providing 
economic and military support to newly established strategic clients in the U.S. and West's own backyard. While these leftist movements did have significant indigenous support, the Reagan administration argued that the U.S.S.R. was seeking to consolidate control over these regimes in order to thwart the "agreed upon" balance of power. Bruce Porter (1984) suggests the policies of Détente led to the deployment of over forty thousand Soviet-armed Cuban troops in Southern Africa, Soviet sealifts/airlifts to its allies at war, and the invasion of Afghanistan, which according to him, were completely atypical of traditional Soviet policies during the Cold War (p. 3).

Overall, Soviet interest in the less developed world was a result of several important political and economic goals. According to Steven David (1986), "they included the establishment of military bases to assist in power projection, control over raw materials, the containment of the West and the People's Republic of China, [and] diverting American resources away from the defense of Western Europe (p. 4)”. In addition, because the Soviets were failing to meet the economic needs of its people, making strategic gains in the less developed world was important for the internal legitimacy of the regime.

Responding to "Soviet gains", the U.S. (and its Western allies through indirect support) worked with local proxies in attempt to fight against a shift in the balance of power. The U.S. simply had to prevent these newly acquired Soviet clients from interfering in nearby U.S. client states. Indeed, balance of threat realists like to point out how the spiraling effect of distrust formed by revolution between the former superpower and the rebel colony often forces the rebel colony to ally itself with the rival superpower. as the rebel colony seeks to expand the revolution at the expense of its former 
superpower for its own protection In the end, to balance of threat realists, it is no surprise that the U.S./West aided neighboring Soviet client states in such countries as Pakistan (against Afghanistan), Honduras (against Nicaragua), and Zaire (against Angola). The strategy was to prevent the spread of Soviet influence, especially in areas demarcated as U.S. and Western spheres.

Regardless of the desires for modernization and independence from foreign interference, Stephen Walt (1992) maintains that the U.S. had to respond to these states and surrounding social movements with uncompromising force, since "revolutions intensify the security competition between states" (p. 4). By destroying the old political infrastructure, revolutions temporally weaken the state, which inevitably causes important international actors to seek to "improve their relative positions either by seizing land or by seeking important diplomatic concessions" (Walt, 1992, p. 44). The bottom line is that the U.S. (as the leader of the West) dismantled Détente precisely because Détente had increased the potential for revolutionary success, and thus Soviet interference, in the Third World.

Afghanistan was the last straw for the U.S. and the West. While a "defensive" action on paper, the Carter administration suggested that a successful Soviet invasion and take-over of Afghanistan placed vital American and G7 interests (and the Western alliance) in jeopardy (could fracture Pakistan and eventually place Soviet troops close to Iranian oil fields). In fact, Shaheen Dil (1977) argues that:

Americans feared that each absolute increase in Soviet influence implied a reduction of American power. The vision of Soviet paramountcy in a part of the world which the U.S. is not willing to acknowledge as within the Soviet sphere of influence is not comforting to U.S. policymakers. (p. 475) 
In addition, now that the Soviet Union had employed the Brezhnev Doctrine with respect to Afghanistan, how else would the Soviet Union respond to the U.S. trying to subvert other socialist client states, especially if its stake in the distribution of power grew even further? Since the Soviets had sought to weaken the U.S. in Central America and Southeast Asia, it was only logical for the U.S. to step in and aid the likes of Osama bin Laden against the U.S.S.R.

The fear of looking weak to your enemy, according to realism, invites aggression. Inevitably, "this fear inclined both governments to view their rivalry as a zero-sum game and to blur the distinction between vital and peripheral interests" (Richter, 1992, 271). Thus, even if Nicaragua, Angola, or Afghanistan had little to no strategic interests for either superpower, each superpower had to act in order to deter increased aggression from the other. The Soviets had to invade Afghanistan in order to demonstrate that it was capable of stopping its satellites from seceding, while the U.S. had to let the Soviets know that it wasn't going to let them threaten its strategic interests in the Middle East.

After all, realists argue that the structure of anarchy in the international system forces states to play by the rules of self-help. Concern for the distribution of power and the bipolar nature of the Cold War inevitably caused each side to seek strategic and economic advantages against the other. One manner in which superpowers extract advantages is by establishing exploitive relations with less powerful peripheral states. By changing the core-peripheral dynamics, revolutions threaten the geopolitical and economic interests of the status quo power. Power distribution in the international system is simply a zero-sum game, especially in a bipolar world. As suggested by Phil Williams (1989) in "U.S.-Soviet Relations: Beyond the Cold War?", "even if their intentions 
towards each other are initially benign, the two great powers are stuck in a security dilemma in which actions taken by one for defensive purposes (such as the U.S.S.R.'s quest for nuclear parity) appear as threatening, aggressive, or expansionist to the other" (p. 274).

War in Nicaragua and other lesser-developed countries during the 1970's initiated a power vacuum, just as World War II had done so in Europe. Seeking to weaken the U.S. and its legitimacy as a strong defender of the Western Alliance, realists suggest the U.S.S.R. stepped in to fill this power vacuum, thereby altering the old distribution of power. From Africa to Southeast Asia and Central Asia, balance of threat realists suggest the balance of power was shifting and that the Soviets were striving to make further improvements in the balance of power. Thus, the Soviets were now free to alter the ideological and strategic orientation of these newly acquired satellite states, once the Soviets had forced them to become dependent on foreign aid.

In sum, an aggressive Soviet Union, bolstered by increased conventional military power was seeking to take advantage of this newly developed power vacuum is what was occurring in the late 1970 's according to realists. They believe the U.S.S.R. significantly increased its foreign aid flows towards the most strategically important countries of Latin America, Africa, and Asia (perhaps even away from Eastern Europe). If this is true, I should also find that the Carter administration, the NSC, Departments of State and Defense, and the entire foreign policy apparatus were primarily concerned with Soviet expansionism in the Third World. The archives should demonstrate that U.S. foreign policy, and the revolutions that were occurring, were primarily viewed through the context of power distribution, the decline of U.S. hegemony, and the weakening of the 
Western Alliance due to the rise of Soviet power in the less developed world. There should be very little evidence in the archives that the U.S. was concerned with the economic interests of U.S. businesses or that bureaucracies competed for different policies.

Structural Marxism and Détente (Core-Periphery Dynamics)

Structural Marxism argues that world capitalism encompasses a system in which the core states exploit the peripheral states. World capitalism is also inherently expansionist as the "key to accumulating capital, enlarging profit shares, and maximizing profits has historically been long distance trade"(McCormick, 1995, p. 2). Desire among core states for higher profit rates and greater wealth abroad inherently conflicts with the desires for economic development in peripheral regions. Thus, the fall of Détente, and the subsequent Second Cold War, was not the result of Soviet aggressiveness or a shift in the balance of power, but the result of the periphery's attempt to climb the core-periphery ladder, which threatened the interests of U.S. and Western capital. Decades of economic exploitation combined with Third World recession in the 1970's simply served to increase the likelihood of revolutions in the less developed world. While the Vietnam example may have increased the likelihood of revolutionary activity during the 1970's (both because of decreased U.S. militancy and as an inspiration in itself), such activity was not the result of a more aggressive Soviet Union during the 1970's. In fact, it could be argued that structural economic shifts, which threatened U.S.'s dominant status within the core itself (Japan and Germany rising) actually forced the U.S. to tighten its grip over the periphery. 
Though structural Marxism contains a "rainbow" of schools, from transnationalists to world system theorists, they all agree that the world capitalist system, seen through five centuries of capitalist globalization, has annexed vital resources from such areas of the world as Latin America, Asia, and Africa, maintaining the Third World in dependency. Because of their overwhelming economic and especially military power, the core states have forced the peripheral states to engage in low-profit economic activities, such as exporting raw materials As world system theory suggests, the core takes these raw materials and creates the high value added manufactured products that creates a relationship of unequal exchange, which benefits the core.

Unlike the increased industrialization that occurs in the core, increasing dependence reflected in an increasing trade gap has been the result in the periphery (Petras et al. 1976, p. 2). Most of the economic benefits of trade "drains" into the hands of the MNCs of the North. For instance, Helen Caldicott (1992) argues that "U.S. multinationals invested \$270 million in Africa and repatriated \$995 million, \$200 million in Asia and received \$2,400 million, and \$900 million in Latin America for $\$ 2,900$ million" (p. 127). The core states and core investors also use institutions such as the IMF and the World Bank as a means of shoving these unfair trading (as well as monetary policies against the South).

For these reasons, it is important to understand that revolutions in the periphery are a result of domestic movements that are seeking to break away from the exploitive economic superstructure. For instance, "revolutionary situations in Central America have been the outcome of a combination of economic and socio-political factors." (Vilas, 1989, p. 52). These economic factors include agriculture driven export, stagnation, and 
high levels of unemployment. As for socio-political issues, Carlos Vilas (1989) cites forced land dispossession, political repression, and institutionalized political exclusion as unequivocal determinants leading to Marxist-Leninists revolutions.

Capitalism created these conditions of exploitation in which the wealthy landowners (the core's bridgehead) made huge profits while the rest of society went illiterate and hungry. The selling of primary products to the core in return for manufactured imports is not only unequal exchange, but it means that much of the local profits from trade end up in the hands of elite landowners who suppress and exploit the peasants. Though the country as a whole loses from unequal exchange, the core ensures that its bridgehead within the periphery is well compensated.

Besides the already sufficient reasons for revolutionaries in the less developed world to fight against U.S. and Western imperialism, there are many other factors to take into account when considering why revolutionary turmoil occurred during the 1970's. For starters, many of the countries that experienced revolutions or significant revolutionary turmoil during the 1970's had some of the worst unequal exchange rates in the world, costing each country millions of dollars. A 1965 study by Gernot Kohler (1998) entitled Unequal Exchange 1965-1995 illustrates these facts in the cases of Nicaragua, Angola, Salvador, and Mozambique. The nations suffered GDP losses of 53\%, 25\%, 13\% and $8 \%$ respectively (Appendix A). Secondly, a cross-national research study based on class exploitation between 1970 and 1972 (right at the start of Détente) developed by Boswell and Dixon (1993), highlights the extremely high levels of class inequality (surplus value extraction) evident in the countries of Nicaragua, Angola, El Salvador, and Iran (p. 695). 
Not only did these countries have politically repressive regimes, but their widening class differences inevitably mobilized the masses and thus spawned revolutionary movements in the less developed world. Further driving the potential for revolution were such factors as the oil crisis of the 1970's (leading to higher fuel prices and thus economic stagnation) and a large increase in Third World debt. In fact, between 1973 and 1980, Third World debt increased by a factor of four, to $\$ 650$ billion (Caldicott, 1992, p. 129).

The inability of the elite in the periphery to push forward modernization and industrialization is precisely why revolutions occurred in the periphery. Brian Meeks (1993), author of Caribbean Revolutions and Revolutionary Theory, argues that revolutions during the Second Cold War in Nicaragua and Grenada were undertaken by nationalists seeking to push their states from the periphery towards the semi-periphery (p. 2). Ultimately, the export-oriented policies of U.S. backed authoritarian regimes had marginalized their respective countries, leading to dependency and economic domination.

As for the argument that that increased Soviet military aggression during the 1970's was responsible for pushing forward and/or helping these revolutions consolidate, Marxists point out that Soviet military spending (according to the CIA's own estimates) had actually "leveled off" beginning in 1975 to a growth rate of just $1.3 \%$ (Haines et al. 2003, p. 124). Once the Soviet economy is taken into account, it is simply no surprise to find that Soviet expenditures did not increase. While Soviet GNP hovered at around 6\% between 1955 and 1964, GNP steadily began to fall thereafter to $5.3 \%$ between 1966 and 1970, 3.7\% between 1971 and 1975, and 2.6 percent during the end of the 1970's (Kennedy, 1989, p. 165). Inefficiency, corruption, and too much military spending during 
the 1950's and early 1960's had begun to suffocate the Soviet economy. Thus, the Soviet Union was simply not in any position to significantly increase its military spending, especially in regards to sending more aid to areas of the less developed world that were not of serious strategic concern. Of course, the Soviets did try to exploit the chaos and instability in areas of strategic concern to the West. However, in the eyes of structural Marxists, the Soviets placed the burden of revolutionary change on the less developed world.

To truly understand why U.S. militancy increased during the late 1970's/early 1980 's it is vital to understand that revolutions in the less developed world are attacked by hegemonic core states with increased fervor whenever there is a crisis in the world capitalist system between the core states themselves. As shown by David Kowalewski (1991), in Kondratieff expansionist cycles and non-hegemonic years (capitalist competition) the relationship between peripheral revolution and core intervention becomes extremely strongly correlated (p. 70). Kondratieff expansionist cycles "present the core nations with the specter of incursions into their increasingly valuable periphery spheres by other competing and growing powers" (Kowalewski, 1991, p. 73)

Looking to the early 1970 's, it is clear that the U.S. used its structural economic power primarily to deal with rising economic competition from Japan and W. Germany, and increasingly looked to stabilize its declining economic hegemony by asserting its financial power globally (Helleiner, 1996, 3). From destroying the Bretton Woods regime by pegging of the dollar to gold to eliminating financial and currency controls, the U.S. sought to remain the dominant core state. 
Kowaleski (1991) also finds that revolutions tend to spike during heightened competition between core states since rising core states may support these revolutions with assistance for their own motives (p. 74). Thus, it should be no surprise that the decline in U.S. hegemony eroded European support for many U.S. interventions, such as U.S. covert operations against Nicaragua. As revolutions rise, competing non-hegemonic core states lose their faith in the ability of the hegemon to ensure international trade and investment, from which the other core states free ride on. Since the U.S. feared such a move by Japan and Western Europe, it made sure it kept its grip on the Atlantic Alliance by restructuring the financial system and intervening in any and all attempts at peripheral revolution. Ultimately, it was not the balance of power threat from the U.S.S.R., but the rise in capitalist competition with Japan and Western Europe (in addition to revolutionary movements) that caused the U.S. to feverishly attack rising revolutions in the less Third World. Destroying Détente and painting the Soviets as aggressive was simply a domestic ploy to ramp up domestic and international support to wage covert and overt warfare in the less developed world.

Thus, although the U.S. and Western Europe/Japan was firmly embedded in seeking to stop revolutionary movements (thus united in military aid towards nonrevolutionary regimes), the Western Alliance tended to weaken whenever the other G7 members viewed the Soviet threat as secondary, the U.S. as weaker, and making advances versus the U.S. (the dominant core power) through economic incentives and political support much more important. That is, the rest of the G7 was willing to begin its pullback of the dominant core state as some G7 states sought to work with some Latin American states that favored some elements of government intervention in the economy. 
However, the U.S. recognized this immediately and engaged in economic and military policies that tightened Washington's leadership of the Western Alliance in the 1970's by destroying Bretton Woods and eliminating financial and currency controls (Helleiner, 1996, p. 3).

Structural Marxist analysis further suggests that structural changes in the semiperiphery during the late 1970 's decreased American tolerance for revolutionary attempts in the periphery itself. Unlike the 1960's and early 1970's, in which the rates of profit making by U.S. MNCs in the semi-periphery were twice as much as the rate of profit within the core itself, the semi-periphery was no longer the golden child of U.S. or core capital by 1979 (McCormick, 1995, p.213). Thanks to the "insidious debt trap and of the extraordinary burden of its servicing, most of the semi-periphery stalled in middevelopment and deteriorated as avenues of profitable investment" (McCormick, 1995, p. 213). Decline in the semi-periphery where U.S. MNCs had advantages against their European and Japanese counterparts, meant that the U.S. now needed to "step up its military commitments abroad to protect and expand America's share (hegemonic status) of global economic opportunities" as well as its leadership in the Western Alliance. In fact, McCormick suggests that Détente itself was a product of U.S. capital's desire to penetrate the semi-peripheral zones within Eastern Europe (McCormick, 1995, p. 213).

It is also necessary to take into account how shifts in the world capitalist system shifted economic power away from the internationalist North to the nationalist South. The rise of Japan and Germany combined with the inability of the internationalists to pry open significant profits from both Eastern Europe and the semi-periphery allowed protectionist, agricultural, and military interests (which favored interventionist policies in 
the periphery) within the U.S. South to dominate the foreign policy landscape. Though initially favoring ISI policies in Latin America in the early 1970's, U.S. policy shifted towards protecting and expanding commodity exports within the periphery regions of the world (Cox, 1994, 124).

Ultimately, revolutions in Vietnam, Angola, and Nicaragua caused Détente to collapse because the U.S. realized it needed to pump up its military power in order to weaken the less developed world's attempt to climb the core-periphery ladder. The decline in U.S. hegemony (especially versus other G7 states according to structural Marxists) and the crisis in the world economy explain why the U.S. attacked revolutionary movements with increased fervor during the late 1970's and 1980's. The U.S. cynically used the "Soviet threat" as the cover-up in explaining why it needed to withdraw from Détente and destroy these rebellions. Calls that the "Evil Empire" was spreading communism were simply a domestic ploy to rally the nation into going along with counter-revolutionary attacks against the periphery. Far from any Soviet gains developing from increased Soviet aggression, structural Marxists suggest that such gains were due to U.S. and Western imperialism.

Therefore, if structural Marxists are correct, then I should find that the overall goal of the U.S. was to stop revolutionary movements that were rising. The U.S. archives should demonstrate that U.S. leaders were not paying attention to the balance of power, but to the structural economic interests of U.S. capital. In addition, structural Marxists would also suggest that the U.S. was extremely worried about how the rise of Japan and Western Europe was affecting the U.S.'s position in the world economic capitalist system. Thus, I should find that U.S. policymakers (chapters four and five) were mostly 
concerned with economic interests in the less developed world. For these reasons, it should be evident that the West was overly protective of its spoils in Africa, Asia, and Latin America as the West itself actually made the gains and exhibited tendencies of aggressive foreign aid donations (chapter three) and actions in the less developed world (chapter five). In turn, I should discover U.S. archives agreeing that the Soviet Bloc was cautious and did not make significant gains (chapter four) and that their economic and military aid was not aggressive in the less developed world (chapter three).

\section{Domestic Politics and Détente}

The domestic politics approach views the interpretations of realists and structural Marxists as incomplete and secondary. It suggests that there is "no objective international system with an independent existence or that systemic pressure is so weak and uncertain that there are indeterminate with respect to the foreign policy choices that states make" (Kapstein, 1997, p. 755). Instead, domestic politics argues that bureaucratic and/or business conflict, not structural explanations, best explains foreign policy because they open the "black box" of a state in order to understand what is happening within the unit. The Myth of Empire by Jack Snyder (1991) points out that to understand a nation's foreign policy "we need to understand the dynamics of policy formulation within the nation-state, especially the role of competing interest groups within various political structures" (p. 2). Viewed from this model, Détente collapsed because domestic interest groups in the U.S., in particular those interests that benefited from the policies of the Cold War, took over the reins of foreign policy.

A leading work on U.S. domestic factors causing the collapse of Détente is David Skidmore's (1996) Reversing Course. Skidmore focuses on the influence of interest 
groups and finds that the shift in Cold War foreign policy that culminated in Détente was due to the political victory of a loose coalition of anti-war activists and international business groups (Skidmore, 1996, p. 3). However, "multinational corporate interests and liberal political supporters, found it difficult to work together, each possessing liabilities that limited popular appeals (Skidmore, 1996 p. 3). The opposition, a "patriotic" conservative bloc that encompassed social reactionaries, the military industrial complex, and Zionists found cohesion within their domestic/international world views.

In fact, this coalition unleashed a conservative movement that removed moderate Republicans and Democrats from Congress in favor of hardliners beginning in 1974. It became so powerful that President Carter was forced to retreat from his liberal internationalist platform. Far from "adjusting" to the decline in American hegemony, Carter was forced to reverse his liberal policies, such as decreasing the rate of growth of the military budget, restricting CIA covert operations, pulling troops from South Korea, and normalizing relations with Vietnam and Cuba. Ultimately, the realist assertion that state executives are immune from interest group pressure fails to appreciate the power of private interest groups as well as sectors with interests in the military industrial complex from creating a succinct and coherent anti-Soviet world view that led to the capture of Congress and important parts of the bureaucracy.

Initiating major policy changes, such as lessening Cold War tensions with the Soviet Union, is also a rather difficult task considering that Cold War interests had entrenched themselves in the U.S. bureaucracy and throughout American society. Dan Caldwell (1991) in The Dynamics of Domestic Politics and Arms Control advances this viewpoint. Caldwell suggests that U.S. Presidents must pay attention to creating a foreign 
policy consensus among key bureaucratic officials and influential elites in Congress, as well as being attuned to the influence of the media, before going ahead with major shifts in foreign policy (p. 4). Carter's failure to do this meant that domestic factors, such as interest groups, public opinion, and the Senate derailed his attempt at completing SALT II negotiations.

The primacy of domestic politics and interest groups in destroying Détente is also cited by Anne Cahn(1998) in Killing Détente. She contends that powerful bureaucratic conservatives, such as Paul Nitze and Richard Pipes, forced the CIA to create an alternative "Team B" to evaluate Soviet military power (p. 2). Team B's assessment of the Soviet threat (in regards to airpower and nuclear missile capability) came up far graver than the previous NIE estimates which ultimately helped galvanize conservative opposition to Détente.

Such work connects well with Graham Allison's (1971) bureaucratic approach which articulates that there is no single maker of foreign policy (p. 3). Policy flows instead from an "almagram of large organizations and political actors who differ substantially on any particular issue and who compete to advance their own personal and organizational interests" (Clifford, 1990, p. 162). All in, interest groups battles decide foreign policy.

Another way interest groups, especially business groups, affects policy is the manner in which their interests parallel with the interests of important bureaucracies that shape U.S. foreign policy. An important example of this is the U.S. military industrial complex (MIC). As argued by David Gibbs (1996), this bureaucracy encompasses the interests of many defense related companies, such as the Rand Corporation and Lockheed 
Martin, and industries, such as electronics, mining, and oil which have vested interests in large military budgets (51). Moreover, the interests of such companies and the MIC parallel for the very fact that bureaus have an inherent tendency to expand, whether or not there is any real need for more of their services (Downs, 1965, p. 439). Their desire for larger budgets and policy relevance pushes them to promote the interests of businesses that depend on them.

Starting in the early 1970's the MIC and its business partners began to lose a large percentage of their share in the national budget and arms exports. The policies of Détente, such as scaling back military spending and military aid to authoritarian regimes, began to hurt the economic interests of U.S. businesses and the bureaucratic power of the MIC. Thus, these groups organized in the late 1970's to create very powerful political lobbies. The goal was to convince the American public that the policies of Détente made the country weak, allowing the Soviets to "expand" in the Third World. Culminating with the Soviet invasion of Afghanistan, the MIC and the pro-military business sectors had their "perfect storm" to force a shift in U.S. foreign policy (Gibbs, 1996, p. 51). These lobbying efforts led to the abandonment of SALT II, a 39 percent increase in military expenditures, and a significant increase in arms exports.

Why would the U.S. paint the Soviet invasion as expansionist when U.S. policymakers had declared in the 1940's and 50's that Afghanistan possessed no strategic importance and that Soviet involvement in the region was a result of U.S. aid to Pakistan? After all, "U.S. officials generally believed that the Soviets gained little offensive strategic value from their relations with Afghanistan" (Gibbs, 1996, p. 53). To explain U.S. policy reversal in 1979 it is pertinent and necessary to understand how the "group 
interests" of the MIC, which invariably linked important business sectors, came to formulate national policy.

Not only did Détente collapse due to interest group and bureaucratic pressures linked with important business sectors, but many within the domestic politics business conflict school suggest that the entire range of policies during the 1970's ebbed and flowed according to where the plurality of business interests lied. Though in agreement with structural Marxism those interventions in the Third World helped to protect and spread U.S. investments, proponents of business conflict would argue that competing business interests are far more significant than structural economic factors in determining policy outcomes.

For instance, the business conflict model contends that a constellation of interests had emerged by the late 1960's and early 1970's that turned U.S. trade policy into the liberal internationalist direction. James Kurth's (1979) The Political Consequences of the Product Life Cycle suggests that the U.S. auto industry, aerospace industry, and banking interests all (thanks to the logic of the product cycle) supported free trade and Détente during the 1970's for the very reason that each of these industries had saturated their established home markets (3). These industries were clamoring to expand and penetrate foreign markets. Jacqueline McGlade (2006) also finds that business conflict was significant in improving relations with the U.S. and the U.S.S.R. Citing increased pressure from computer manufacturers, capital equipment firms, and agricultural producers, the U.S. shifted policies and initiated Détente (p. 14, para. 1).

Facing stiff competition from Japanese and European start-up firms with lower overhead costs some industries made an abrupt turn towards protectionism, leaving 
Détente with very little political support from the U.S. elite. In fact, the final phase of the "product life cycle" theory suggests that once industries can no longer compete abroad with more competitive and innovative firms, they seek protectionism. With international trade in the Eastern Bloc no longer important to U.S. industrial and financial sectors, and corporations facing increasing nationalism in the less developed world the tide was turned in favor of the "labor-repressive business sectors" (Cox, 120).

Competition between business internationalist/capital intensive firms and nationalist labor/repressive firms during the final years of Détente, not the prospects of Soviet gains, is precisely what determined U.S. foreign policy towards Central America. The business conflict approach highlights that labor-intensive firms were far more antagonistic towards revolutionary movements for the very fact that they depended on cheap labor and were vulnerable to expropriation measures. In contrast, capital-intensive firms and banks were willing to work with the Sandinistas, so long as they promised to pay Nicaragua's debts (Cox, 1994, 121). In essence, U.S. foreign policy was developed depending on which business sector captured the foreign policy-making process. More pointedly, it was the realization that the plurality of firms benefited from export-led industrialization policies in Central America that altered the playing field in favor of interventionist and militant policies towards revolutionary movements.

Overall, whether it is the political pressure of interest groups, the inertia of interventionist policies of the MIC or business conflict the domestic politics approach shows that it is imperative to open up the "billiard ball" of the state. Societal approaches conclude that, contrary to the realist view, there is no single national interest that can be promoted by the executive branch. Not only in regard to deterring Soviet national interest 
gains, but also in regard to maintaining the Atlantic Alliance, domestic policy theorists suggest that these issues are way on the backburner compared to advancing the selfish interest of large and powerful organizations. For instance, they would suggest that the recent invasion of Iraq was not founded on the premise of promoting the national interest (America is bogged down, Iran may have gained a new sphere of influence), but promoting the narrow-minded interests of certain powerful interest groups.

\section{Moving Forward}

My dissertation shall now trace the history of Western-Soviet Bloc competition and the importance of the less developed world in relation to this competition. More specifically, chapter two will also deploy the piercing lenses of historical analysis in order to provide a preliminary assessment of the gains and losses of the Soviet Bloc during Détente (chapter two). Did the Soviets, as predicted by balance of threat realists, make significant gains during the middle-to-late 1970's.

Afterwards, I go ahead and measure the foreign aid contributions (especially military) of the Soviet Bloc and the West towards the less developed world. My analysis will to begin to examine whether balance of threat realism or structural Marxism, best explains U.S.-Soviet/Western-Soviet Bloc competition in the less developed world during the 1970 's. Since it is only my first examination, I shall still need to wait for the other chapters to come to a final conclusion.

Examining the foreign aid data is simply a requirement considering that any potential Soviet gains during Détente could have been the result of anti-Western revolutionary turmoil without the initial or further backing of the Soviet Union. The Soviet Bloc did provide increased military and economic support towards newly installed 
revolutionary governments in the less developed world that were either anti-American or anti-Western during the late 1970's. However, I must look deeper at the foreign aid contributions in order to determine whether the Soviets placed the burden of revolutionary change on the less developed world or whether they themselves took a very active approach in seeking to reverse the balance of power. In fact, few analysts have bothered to thoroughly measure Soviet aid patterns during and after Détente as a way of gauging Soviet intentions, relying for the most part on assumptions based on the U.S.S.R.'s authoritarian political system, incomplete data, and/or inflated conventional military aid expenditures.

I also reject aggregate aid comparisons in favor of a historical/quantitative method. To truly get at the heart of the matter I believe I have to analyze Soviet and Western foreign aid (especially military aid) contributions to the most strategically significant countries in the region, the timing of such aid, and other important processtracing/historical factors. Large foreign aid allocations (especially military) towards nonstrategic countries could invariably bias the results. Some countries in the less developed world were more strategic than others. The timing of foreign aid allocations (especially military) also goes a long way in explaining whether the Soviets were seeking to make gains in the face of claimed Western retreats.

Once my interpretive quantitative analysis has determined whether the balance of power shifted and whether the Soviet Union became aggressive with foreign aid contributions in the less developed world during the 1970's (both against the Western Alliance and the U.S. itself), taking advantage of revolutionary turmoil in the less developed world, I shall go ahead and study the policy archives (chapter four) of the U.S. 
intelligence agencies (such as the Defense and State Departments) in the national security archives as well as the presidential archives of the Nixon, Ford, and Carter administrations. These archives will provide important documentation describing what policymakers were thinking and how they were analyzing the developments of the late 1970's. Do they cite Soviet aggression and advances in the less developed world as the key reason for increased U.S. involvement? I shall also analyze Soviet documents to better understand what policy decisions Soviet policymakers made and why they made them. Within this archival section, I shall also determine whether revolutionary turmoil was a primary or secondary reason for Détente's collapse as I analyze the archives for the possibility that Soviet advances in the nuclear realm were much more significant in causing Détente's collapse.

Chapter five then moves to comb the U.S. archives in order to analyze the U.S. response during this time period in the less developed world. The U.S. response will help give a lot of insight as to how the U.S. was reading the situation in the less developed world during this time period. Was the U.S. sleeping at the wheel (as described by balance of threat realists) or engaged in aggressive actions (as argued by structural Marxists)?

Chapters four and five will allow me to introduce the important theory of domestic politics. Supporters of this theory would contend that the archives will highlight the overwhelming influence of interest groups within the U.S. bureaucracy. In their view, the U.S. response to revolutionary turmoil had nothing to do with balance of power or agreed upon economic interests, but with the dominant domestic groups promoting and protecting their respective interests. 
Structural Marxism and balance of threat realism can also be tested in the archival chapters (four and five). For structural Marxists, the archives should show that U.S. policies drove these states into the hands of the Soviets. Pointing to former U.S. diplomat Cole Blasier (1976), structural Marxists would concur that U.S. intervention had "the effect of achieving what it sought to avoid" (p. 6). Instead of paying attention to the "root causes" of revolution (social discontent) U.S. policymakers consistently ignored the moderate nationalists in favor of all or nothing policies. Balance of threat realists would counter that the archives should confirm Soviet Bloc aggression. They suggest U.S. policymakers were most concerned with Soviet adventurism throughout the less developed world. 


\section{REFERENCES}

Allison, G. (1971). The Essence of Decision. Little Brown Publishing

Bach, Q. (2003). Soviet Aid to the Third World. Book Guild

Blasier, C. (1976). The Hovering Giant: US Responses to Revolutionary Change in Latin America. University of Pittsburgh Press.

Boswell, T., Dixon, W. (1993). "Marx's Theory of Rebellion.” American Sociological

Review. Volume 58, pp. 681-702

Cahn, A. (1998). Killing Détente. Penn State.

Caldicott, H. (1992) If you Love This Planet. WW Norton

Caldwell, D. (1991) The Dynamics of Arms Control and Domestic Politics. University of South Carolina Press.

Calleo, D. (1996). "Restarting the Marxist Clock: The Economic Fragility of the West." World Policy Journal. Summer, pp. 212-225

Clifford, Gary. (1990). "Bureaucratic Politics.” The Journal of American History, Vol. 77, pp. 161-168

Cox, M. (1990). "From the Truman Doctrine to the Second Superpower Détente." Journal of Peace Research, Vol. 27, pp. 25-41.

Cox, R. (1994). Power and Profits: U.S. Policy in Central America. University Press of Kentucky.

David. S. "Soviet Involvement in Third World Coups." International Security. Vol. 11, pp. 3-36.

Dil, S. (1977) "The Cabal in Kabul.” The American Political Science Review. Vol. 21, pp. $468-476$

Dixon, M., Jonas, S. (1983). Revolution and Intervention in Central America. Synthesis Books

Down, A. (1965) “A Theory of Bureaucracy." American Economic Review. Vol. 55, pp. $439-446$

Finley, D. How Much Military Spending is Enough? Retrieved February 2006 from: http://home.pacbell.net/dsfinley/military/military_spending.html 
Fordham, B. (1997). Domestic Politics, International Pressure, and Policy Change. Retrieved on January 2005 from http://www.lib.unb.ca/Texts/JCS/SPR97/articles/fordham.html

Gibbs, D. (1996). "The Military-Industrial Complex: Sectoral Conflict, and the Study of U.S. Foreign Policy.” pp. 41- 60 in Ronald W. Cox, ed., Business and the State in International Relations. Westview Press.

Haines, G., Leggett, R. (2003) "Watching the Bear: Essays on CIA/'s Analysis of the Soviet Union." Washington DC Center for the Study of Intelligence.

Hart, J. (1983). The New International Economic Order. St. Martin's Press.

Harvey, D (2005). “The New Imperialism.” Oxford University Press.

Helleiner, E (1996). States and the Reemergence of Global Finance. Cornell University Press.

Herz, J. (1980). International Politics in the Atomic Age. Columbia University Press.

Kanet, R. (1992) Soviet Foreign Policy and East-West Relations. Pergamon Press.

Kapstein, E.(1995). “Is Realism Dead?” International Organization. Vol. 49, page 751774.

Kennedy, P. (1989) The Rise and Fall of Great Powers. Vintage Books.

Kohler, G. (1998). Unequal Exchange 1965-1995. Retrieved April 2006 from: wsarch.ucr.edu/archive/papers/kohler3.htm

Kowalewski, D. (1991) “Core Intervention and Periphery Revolution, 1821-1985.” The American Journal of Sociology. Vol. 97, pp. 70-95

Krasner, S. (1985) Structural Conflict. University of California Press.

Kurth, J. (1989) "The Political Consequences of the Product Life Cycle." International Organization. Vol. 33, pp. 1-34.

Lagon. M. (1992). “The International System and the Reagan Doctrine: Can Realism Explain Aid to Freedom Fighters?” British Journal of Political Science . Vol. 22, pp. 3970.

Meeks, B. (1993).Caribbean Revolutions and Revolutionary Theory. MacMillion Caribbean 
McCormick, T. (1995). America's Half Century. Johns Hopkins University Press

McFarlane. N. (1983). "The USSR in Third World Conflicts." Programme for International and Security Issues

McGlade, J. (2006). "Expand World Trade or Security?” XIV International Economic History Congress, Session 11. Retrieved December 2005 from http://www.helsinki.fi/iehc2006/papers3/McGlade.pdf

Mittal, A. (2006). "Playing Politics with Aid: The Unholy Trinity of Defense, Diplomacy and Development in the War on Terrorism." Common Dreams. Retrieved May 4, 2006 from http://www.commondreams.org/views06/0227-24.htm.

Morgenthau, H. (1993). Politics Among Nations. Knopf Inc.

Morgenthau, H. (1962). "A Political Theory of Foreign Aid.” American Political Science Review. Vol. 56, pp. 301-309

Olson, M. (1971). The Logic of Collective Action. Harvard University Press.

Oneal, J. (1990). "Testing the Theory of Collective Action." The Journal of Conflict Resolution.

Vol. 34, pp. 426-448

Organization for Economic Co-operation and Development. (1971-present). Stat Extracts: Development Aid. Retrieved May 26, 2006 from http://stats.oecd.org/WBOS/index.aspx

Petras,J., Rhodes, R. (1976). "Competition and Domination of the World Capitalist Powers." Mexican Journal of Sociology.

Porter, B. (1984). The USSR in Third World Conflicts: Soviet Arms and Diplomacy in Local War, 1945-1980. Cambridge University Press.

Richter, J. (1992) "Perpetuating the Cold War: Domestic Sources of International Patterns of Behavior.” Political Science Quarterly, Vol 107, pp 271-301.

Rothgeb, J. (1981). "Loose vs. Tight: The Effect of Bloc Structure upon Foreign Interactions." The Journal of Politics. Vol. 43, pp. 493-511

Rummel, R. (1976). Peace Endangered. Beverly Hills Publications 
Sempa, F. (2004). Ronald Reagan and the Collapse of the Soviet Empire. Retrieved May 2006 from http://www.unc.edu/depts/diplomat/archives_roll/2004_07-

09/sempa_reagan/sempa_reagan.html

Skidmore, D. (1996). Reversing Course: Carter's Foreign Policy, Domestic Politics and the Failure of Reform. Vanderbilt University Press.

Stiglitz, J. (2003). Globalization and its Discontents. W. W. Norton \& Company.

Snyder, J. (1991). The Myth of Empire. Cornell University Press.

United State Disarmament Agency (1975-1979). World Military Expenditures and Arms Transfers. pp. 128-131

Vilas, C. (1989). "Revolutionary Unevenness in Central America." New Left Review. Issue 175 , pp. 50-72.

Walt, S. (1992). “Revolution and War.” World Politics. Vol. 44, pp. 321-368

Williams, P. (1989) "US-Soviet Relations: Beyond the Cold War." International Affairs, Vol. 65, pp. 273-288.

Woolf, A., Kerr, P. Nikitin, M. (2008). “Arms Control and Nonproliferation: A Catalog of Treaties and Agreements." Congressional Research Service. Retrieved January 2006 from http://www.fas.org/sgp/crs/nuke/RL33865.pdf 
Chapter II: Tracing Soviet Gains in the Less Developed World during Détente Introduction

Chapter two will provide an historical analysis of Soviet Bloc strategic gains/losses in the less developed world during Détente. Before chronicling Western and Soviet competition in the Third World during Détente, however, I will highlight the historical importance of the less developed world in regards to the Cold War. I shall also trace the enormous advantages of the U.S./West when it comes to both strategic military power and foreign aid allocations to the less developed world.

Containing the Soviets and Controlling the Third World Rebuilding Western Europe at the Expense of the Third World

Notable Cold War historian Melvyn Leffler's (1992) A Preponderance of Power, an account of the origins of the Cold War based on new U.S. archival material, suggests that "fear and power...not unrelenting Soviet pressure" was the driving source of U.S. policy at the onset of the Cold War (p. 51). In fact, an assessment report by U.S. defense officials following World War II confirms "that the Soviets had no long-range strategic air force and meager air defenses" (Leffler, 1982, p. 23). They also considered the Soviet navy ineffective and stated that: "The U.S.S.R. will require approximately 15 years to overcome wartime losses in manpower and industry, 5 to 10 years to develop a strategic air force, 15 to 20 years to construct a modern navy, [and] 10 years to refurbish military transport” (Leffler, 1982, p. 51)

Instead, U.S. foreign policy was driven by concerns over the "decline of British power, the economic devastation of Germany, the dollar shortage in Western Europe, and the threatening strength of communism in Greece, Italy, and France" (Leffler, 1982, p. 
51). U.S. policymakers simply understood that the Soviets were down. U.S. fears and U.S. policy still focused on countering the possibility that "the Soviet Union might take advantage of such developments" in the future (Leffler, 1982, p. 51). However, for the time being, the primarily concerns of U.S. policymakers dealt with defending their new allies and countering the potential rise of indigenous threats within the less developed world.

In seeking to counter the possibility of a rising Soviet Bloc decades later, U.S. policy thus focused on rebuilding Western Europe and Japan. Considering their enormous military and economic potential, this was seen as essential to enhancing the balance of power advantages of the U.S. over the Soviets. U.S. planners did not wish for these industrial states to be controlled by any hostile power. George Kennan (1946), considered the primary architect of Soviet containment policy, underscored the importance of rebuilding and controlling the industrial centers of the world. Kennan (1946) believed that harsh economic sanctions against former US enemies would result in Soviet-friendly communist parties coming to power and so he pushed for policies that would result in large-scale economic development in Western Europe and Japan (p. 4, para. 3). After all, he stated that "gauged against Western world as a whole, [the] Soviets are still by far the weaker force.....their success will really depend on the degree of cohesion, firmness, and vigor which Western world can muster" (Kennan, 1947, Section: "Practical Deductions From Standpoint of US Policy”, para. 3)

To finance the development of Japan and its European allies, however, the U.S. had to ensure stable access to cheap raw materials in the less developed world. In his analysis of U.S. archives Leffler (1992) points out "resisting communist or anti-Western 
forces in the Third World" was crucial "since the prosperity and stability of these areas was seen as being dependent on their [Western Europe and Japan] having free access to the raw materials and markets of the Middle East and Southeast Asia” (p. 51) After all, Western Europe's development historically came at the expense of the periphery as "superior militaries and state organizations allowed the Europeans to turn the conditions for international trade heavily in its favor" (O’Brien, 1982, p. 2). Ensuring continued European access to markets in the less developed world following WWII was also essential for the development of U.S. manufacturing, since Europe would then be able to increase imports of highly valued American products.

Indeed, controlling the less developed world was also considered immensely important for U.S. corporations and U.S. strategic interests. For instance World War I witnessed the U.S. becoming the largest importer of strategic raw materials during World War I (Dunn, 1987, p. 106). So expansive was the reach of U.S. power that by 1929, "U.S. imports of non-fuel minerals were greater than the rest of the world combined" (Dunn, 1987, p. 107).

The post-WWII era, however, witnessed the rise of significant revolutionary turmoil throughout the areas of the less developed world, especially in areas that were previously under Western European control. Starting in Greece and continuing into such former European colonies as Vietnam (France's major colonial dollar earner), Indonesia (Netherlands's major dollar earner, and Malaysia (Britain's most profitable colony), it was obvious that nationalist revolutions in the Third World were beginning to threaten the Western "liberal" economic order. Consequently, the U.S., as the new leader of the Western Bloc, and Western Europe began to work together to quash third world revolts. 
In fact, it was so important to protect the interests of Western Europe that U.S. commercial interests in Africa often took a backseat to defending the interests of the Western Alliance (Nwaubani, 2001, p. 4). Aiding its allies explains why the U.S. quickly came to the Western Alliance's aid in Indonesia, Malaysia, and Vietnam. Using documents from the Truman and Eisenhower administration, Nwaubani (2001) argues that U.S. policymakers were most concerned with ensuring continued access to raw materials for Britain and France (p. 4).

Working with Europe to Encircle the Soviets Militarily

In its foresight of possible Soviet meddling in the less developed world in the future, the early 1950's witnessed the U.S. push for permanent strategic and military superiority during the onset of the Cold War. With the help of its Western Allies, the U.S. worked to create an overseas supply of military bases that practically encircled the U.S.S.R. following WWII. To do this the U.S. negotiated with the British attain access to military bases and air facilities in the Middle East. Deals with the Germans, French (for North Africa), Turks, and Japanese vastly expanded the reach of U.S. military power.

\section{Using Foreign Aid to Control the Third World and Contain the Soviets}

Countering Soviet expansionism and controlling the less developed world also consisted of large allocations of military and economic aid to allies in the Third World. There is significant evidence that U.S. aid flows (not even including the rest of the G7) and assistance to pro-U.S. regimes vastly exceeded the Soviet Union's foreign aid allocations. Total U.S. economic and military aid to the Third World from 1945 to 1980 amounted to about $\$ 200$ billion (Trofimenko, 1981, p. 2). On the other hand, a comparable study by Gu Guan Fu finds that the Soviets provided about $\$ 65$ billion worth 
of economic and military aid within the same time period (p.74), of which only $\$ 30$ billion of which were allocated between 1945 and 1975 (Fu, 1983, p. 74). This points to a significant disparity in strategic foreign aid in favor of the U.S. However, these "figures [alone] do not express the full extent of U.S. infiltration into developing countries, countless less conspicuous instruments of influence, from banking credits and managerial assistance all the way to aid in infrastructure development" (Trofimenko, 1981 p. 2).

\section{Section Conclusion}

Overall, superior military positioning and strategic influence (both economic and military) is why Third World conflict during the early Cold War was largely confined to regions near the U.S.S.R. or China. U.S. military dominance with respect to air power, naval power, transportation of troops/equipment, artillery, and tanks meant the U.S. was the dominant conventional weapons state (Halliday, 1996, p. 20). The lack of comparable military power (mostly conventional) on the Soviet side was very much an "important geopolitical restraint that allowed the Western powers to remain dominant in the Third World during the 1950's and 1960's (Allison et al, 1990, p. 2)." These facts, combined with a significant disparity in foreign aid assistance in favor of the U.S., meant the Soviets really had no hope of expanding their influence in the Third World.

The Tide Turns?

However, U.S. defense officials and U.S. hawks argued that Soviet strategic and conventional military force had significantly improved by the 1970's, ushering in a completely different Cold War picture. Wayne Shroeder (1979) argues that the trend towards increased Soviet defense expenditures began in the mid-1960s (para. 9). He suggests that following the "Cuban Missile Crisis, the Soviets changed the economic 
emphasis of their Seven-Year Plan (1959-1965) to reflect increased defense investment (particularly in the strategic area) as the means by which to bolster Soviet military power and political influence (para. 6)." Kim Holmes (1986) also painted a stark picture for the American public (para.1). He insisted that Soviet upgrades to their conventional navy and air force placed vital American interests in the less developed world in serious danger (Holmes, 1986, para. 1). In addition, U.S. defense officials pointed out that the Soviet Bloc was now superior to NATO in surface combat ships (230, v. 175), attack submarines $(234$, v. 78$)$, tanks $(20,500$, v. 7,000$)$, artillery $(10,000$, v. 2,700$)$ and fixedwing warplanes $(3,525$, v. 2,050$)$ (Time, 1978, para. 6).

The Effects of Détente

However, the Soviet economy paid a heavy economic price pursuing mutually assured destruction (MAD) and increasing its ability to project force. For instance, Soviet leader Nikolai Khrushchev argued that the arms race (and a bloated military budget) had begun to cripple the Soviet economy leading to lower growth rates and economic stagnation (Ned, 1994, p. 373). Seeking to "attract credits, investments, and technology from the West" Khrushchev (just as Gorbachev later on) attempted to "implement domestic reforms and seek accommodation with the West” (Ned, 1994, p. 373). Thus, Soviet leaders pushed for Détente. They calculated that less military spending, as well as more trade with the West, would be in the long-term interests of the Soviet Union.

Policymakers in the U.S. also came to the conclusion that a relaxation of tensions (Détente), promoted through economic trade agreements and the signing of the SALT I nuclear delivery systems treaty, would serve to improve the U.S.'s economic balance sheet. Just like the Soviet economy, the U.S. economy was also beginning to slump. The 
Vietnam War and rising economic competition with Europe and Japan was beginning to chip away at the economic power and leadership of the U.S.

The U.S. camp also came away from Detente believing the negotiations had frozen the territorial balance of power. Allison and Williams (1990) point out that for the U.S., Détente amounted to a new code of conduct in which the U.S.S.R. would cede the Third World to Western influence (p. 3). Thus was the viewpoint of U.S. National Security Advisor Henry Kissinger. He firmly believed "the superpowers [had] committed themselves to exercise restraint [in the less developed world]" and that "in our minds, efforts to reduce the danger of nuclear war by the control of arms had to be linked to an end of the constant Soviet pressure against the balance of power (Allison et al, 1990, p. 3)."

In contrast, many within the Soviet camp grasped Détente as a victory. While acknowledging that the signing of Détente did limit the continuous development of Soviet nuclear weapons, the U.S.S.R. did not view Détente as an agreement that limited their support for national liberation movements (Trofimenko, 1981, para. 4). When these movements benefited their strategic interests, the Soviets believed it was within their right to expand their sphere of influence. So long as their proxy intervention would not lead into a potential nuclear showdown, Soviet leaders believed they had every right to seek influence in the less developed world (Trofimenko, 1981, para. 6). In essence, the Soviets felt that along with the nuclear parity the U.S. ceded, the U.S. also ceded its dominance of the Third World. 


\section{Soviet Gains during Détente?}

Many U.S. officials and balance of threat realists believe the carrots of accommodation and trade, enshrined within Détente, failed to block a significant increase of Soviet "meddling" in the less developed world. In their view, Soviet assistance towards Nicaragua, Angola, Vietnam, and other revolutionary movements/regimes led to significant Soviet gains in the less developed world during Détente. Regardless of the past power imbalance that significantly favored the U.S./West, balance of threat realists argue that a decline in U.S. hegemony in the 1970's, revolutionary turmoil in the less developed world, and increased Soviet military power during the late 1960's created the conditions necessary for a shift in the balance of power. The new environment invited the Soviets into the West's sphere of influence.

In contrast to these claims, this chapter will chronicle that the Soviet Bloc barely improved its balance of power standing in the less developed world during the Détente time period. Partial gains in Angola, Ethiopia, Vietnam, and Nicaragua seemed to have been offset by losses elsewhere in the Third World. Soviet defeats in Egypt, Peru, and Chile and the Sino-Soviet split were significant blows to Soviet interests in the less developed world.

Soviet Involvement and the Competition for Allies in the Third World

\section{Section Introduction}

The current section now aims to provide a historical account of the strategic competition between the U.S. (as the leader of the Western alliance) and the Soviet Bloc in the less developed world that took place during Détente, which according to U.S. policymakers, shifted the global balance of power in favor of the Soviet Union. My main 
goal is to examine whether or not the Soviets made vital strategic gains in the less developed world during Détente.

Of course, some regions had more implications for the breakdown of Détente than others, as they were more central to considerations of a definitive shift in power distribution between the U.S. and the U.S.S.R. The Middle East/Northern quadrants of Africa, with vast amounts of strategic energy resources and the Buffer Zone, with its respective proximities to important interests of both superpowers were certainly much more important (especially to the U.S.) during the 1970's than either Southeast Asia or Southern Africa.

\section{Methodology}

In defining Soviet gains and defeats in the less developed world between 1972 and the collapse of Détente around 1979-1980 (vast increases in U.S. military spending, heightened counter-revolutionary activity, and breakdown of SALT II negotiations) I will use several definitions (slightly altered) developed by Ted Hopf (1992). A Soviet gain will come to refer to a victory that involves the "ascension to power by some group committed to Soviet positions on fundamental questions of foreign policy and domestic policies... or the removal of some group committed to policies consistent with U.S. or Western policy preferences" followed by a close Soviet alliance (Hopf, 1992, p. 22).

On the other hand, Soviet losses will include cases in which a "pro-Soviet regime was removed from power... or the removal of some group committed to policies consistent with Soviet policy preferences" (Hopf, 1992, p. 22) followed by a close U.S. or Western alliance. Considering Chapter three will go much deeper in measuring Soviet aggressiveness (measuring significant foreign aid, especially military), I will now simply 
provide a historical analysis of U.S.-Soviet Third World competition and trace gains/losses of the U.S.S.R.

Asia

\section{Section Introduction}

To understand U.S.-Soviet (Western-Soviet Bloc) competition in the less developed world during Détente period, I will begin in Southeast Asia with Vietnam. I begin here because there is some evidence that the U.S., through the signing of Détente, was hopeful that a new age of Soviet restraint would ensue in Southeast Asia. Others, such as John Lewis Gaddis (2004) also interpreted U.S. actions as accommodating to the U.S.S.R.'s improved power position (p. 264).

\section{Vietnam, Laos, and Cambodia}

Those who believed the U.S.S.R. would link Détente with an end to its involvement in the region were clearly wrong. Regardless of the negotiated settlement of 1973, ending U.S. involvement in the conflict, the Soviet Union's pursuit into Southeast Asia did continue. According to the U.S. Library of Congress, the Soviets stepped up their military assistance and provided over $\$ 800$ in military assistance to Vietnam in 1978 (1987, para. 4). This was considered very alarming due to the fact that U.S. military aid to Southeast Asia had significantly decreased.

The Soviets, working together with Vietnam, also allocated military resources to the revolutionary forces in Laos and Cambodia during the late 1970's. Such assistance was crucial as it helped the revolutionary forces in Cambodia (partial victory as Vietnamese-backed rebels only took over the urban areas) and Laos overthrow their oppressive Chinese and U.S. backed authoritarian governments. Overall, this maneuver 
did result in additional Soviet gains. The Soviets gained access to Haiphong harbor, Da Nang airfield, and Cam Ranh Bay. These ports and airfields, located in Cambodia and Laos, were very strategic for the U.S.S.R. It gave them crucial access to the Indian Ocean.

Consequently, the U.S./West blasted the Soviets for acting in an aggressive manner. By acquiring strategic bases in Southeast Asia, U.S. policymakers and U.S. hawks argued that these

developments have put Soviet bombers within two hours of the Straights of Malacca, used by the bulk of the shipping in the region and through which most of Japan's oil passes from the Middle East. Soviet ships and planes now could also easily monitor movement at the American naval bases in the Philippines, the South China coast, and the Straits of Malacca. (Keleman, 1984, p. 342)

Nevertheless, Soviet improvements in the combat effectiveness of the Soviet Pacific fleet, through the acquisition of strategic bases, still left the "U.S.S.R. as marginally inferior to the U.S. Pacific Fleet, which had a more complete network of bases in the area" (Keleman, 1984, p. 341).

\section{The China Split}

Soviet bases in Southeast Asia would not have been acquired without the Vietnamese invasion of Cambodia in 1978. Upon further review, however, it is important to recognize the role of China and the U.S. in creating this opportunity in the first place. Although Vietnam already possessed some influence in the states of Cambodia and Laos during the late 1970's, it can be argued that Chinese destabilization campaigns (fearing increasing Soviet power in Asia) against Vietnam, through the use of its Cambodian and Laotian proxies, pushed the Vietnamese to invade. John Pilger (1997) makes this very 
point (p. 47). He contends that by economically and militarily supporting Pol Pot's massacres (against ethnic Vietnamese) and incursions into Vietnamese territory, China and the U.S. gave Vietnam (especially) and the Soviet Union the pretext to move into Cambodia in 1978 (Pilger, 1997, p. 47).

The consequences of the Sino-Soviet split reverberated beyond Southeast Asia. Soviet power was now checked throughout the rest of Asia. The communist dominoes were not going to continue to fall. Any further Soviet incursions in the region would have instigated a large-scale Chinese and American response. Both U.S. officials (hence Nixon's 1972 China visit) and Soviet leaders recognized that Beijing no longer wished to subjugate itself to Moscow.

ASEAN

Another reason as to why the dominoes were not going to continue to fall is because of the rise of ASEAN (The Association of Southeast Asian Nations). The ascendance of ASEAN, which included the states of Malaysia, Indonesia, Thailand, Philippines, and Singapore) ultimately helped curtail any further Soviet and Vietnamese gains in Southeast Asia. For instance, "the ASEAN states worked together to come to the aid of Thailand (internal problems and facing a political threat from Vietnam)" (Kurus, 1993, p. 822). The ASEAN states were also effectively able to use the UN Security Council to isolate Vietnam internationally as the majority of the world (91-21) called upon Vietnam to withdraw its troops from Cambodia (Kurus, 1993, p. 822).

While many suggest that severance of the West's economic linkages with Laos and Vietnam was a major blow for the Western Bloc, it is very important to recognize that the rise of ASEAN during the final years of Détente was extremely beneficial for the 
West. Donald Weatherbee (1978) cites how "the ASEAN export economies had been integrated [during the final years of Détente] into the international trading framework of the industrial economies of the Western world with $61 \%$ of ASEAN's exports going to the U.S., Japan, and Europe" during the latter years of Détente (p. 415). Western imports also accounted for just over half of all imports to the ASEAN countries as well. In addition, Weatherbee (1978) points out that U.S. economic assistance to ASEAN between 1974 and 1978 amounted to 1150 millions of dollars (p. 415). France, the UK, Italy, and West Germany also provided significant support (Weatherbee, 1978, p. 416). Ultimately, Weatherbee's data suggests that Europe (and the US) discovered another outlet in which to obtain the raw materials they desperately desired.

The economic policies chosen by ASEAN elites had strong support in Western and Chinese circles. They believed the policies helped contain the Soviet-Vietnamese threat. Indeed, Acharya Amitav (1991) points out that Western and ASEAN political elites both talked about how rapid economic development in the region would help counter the emerging domestic and international communist threats (p. 161).

The West did not just provide economic assistance. In addition, the economic aid was very significant as it helped the ASEAN nations overcome the internal threat of communism. However, the West also backed up their economic aid with "security" guarantees and moderate lines of military credit (Weatherbee, 1978, p. 414).

\section{Section Conclusion}

As I analyze the balance of power before and after Détente, I find it difficult to say the U.S.S.R. made significant gains in Asia. The consolidation of Vietnam into one country, the invasion of Laos, and the partial takeover of Cambodia certainly provided 
important strategic, economic, and military gains for the Soviet Bloc. We can quantify this as at least two gains for the Soviets. However, one must also understand how Soviet gains and revolutionary movements in Southeast Asia rallied China against the Soviets in Southeast Asia. The Sino-Soviet split certainly helped, in the eyes of the West (the U.S. archives will show this) to offset the Soviet gains of Vietnam, Laos, and Cambodia. Having China as a nemesis throughout the entire Asian continent, whereas it was previously confined to Central Asia, was a huge blow to the Soviets. Soviet revolutionary gains also served to rally the nearby states (pro-Western orientation) to Vietnam to form an economic bloc in the form of ASEAN.

Moreover, as it relates to the balance of power, it is important to mention that the additional strategic ports gained by the Soviet Bloc were simply not enough to counter the "complete" network of bases devised by the U.S (Owen et al, 2005, p. 13). Strategic naval bases for the U.S. in Japan, Philippines, South Korea, Malaysia, and Singapore were far more strategic and technologically advanced than those gained by the U.S.S.R (Owen et al, p. 13). Therefore, it is hard to suggest that the Soviets had made significant gains in Asia during Détente.

\section{Middle East}

\section{Section Introduction}

No other region in the less developed world was more important for the Western Bloc during Détente than the Middle East/Northern quadrant of Africa region. The Middle East possessed (and still possesses) oil and natural resources that are extremely vital for the U.S., Western Europe, and Japan. Thus, the strategic zones of the Persian 
Gulf, Suez Canal, and all of the shipping lanes throughout the Horn of Africa had to be military defended against any internal and external enemies.

A snapshot of the competition between the West and the Soviet Bloc in the Middle East in 1972 reveals a region with strong Western influence. With a firm military ally in Israel and a variety of pro-Western Arab governments, the West certainly had the upper hand in the Middle East as the superpowers reached Détente. While the Soviet Bloc provided little military aid towards the most strategic countries of the region, Western Europe and Japan provided a total of 1.1 billion of military aid to Israel, Saudi Arabia, the UAE, Lebanon, Kuwait, and Jordan between 1967 and 1976 (USDA, 19671976, p. 68).

Soviet and Western Bloc Competition in the Middle East

The late 1960's/early 1970's witnessed an increased effort on the part of the Soviets to gain more leverage in the Middle East. With their nationalist postures, Egypt and Syria became the primary vehicles through which the U.S.S.R. and the Warsaw countries could pursue these interests in the Middle East. Anti-Zionism in the region also provided a perfect opportunity for the Soviet Bloc to move in to the Arab world.

As far as the Soviets were concerned, their actions were defensive. Soviet leaders believed they were responding to the previous aggressive actions on the part of the West. For starters, the Soviets "regarded the Baghdad Pact (U.S. Buffer Zone Alliance with Iran, Pakistan, and Turkey during the 1950's and 1960's) as a direct threat to its security (Slater, 1990, p. 565). They also believed the U.S. had managed to create a very powerful bloc of American-backed Arab regimes within striking distance of the U.S.S.R.'s southern flank Finally, Soviet leaders were also very much concerned over the recent 
"deployment of U.S. aircraft carriers and (nuclear-armed) submarines in the Mediterranean" (Slater, 1990, p. 565). As a result, the Soviet Bloc "leapfrogged over Dulles's northern tier straight into Egypt, the Middle East's southern rear and front gate to Africa" (Slater, 1990, 568).

Policymakers in the U.S. did not interpret increases in Soviet military sales to the Middle East and alliances with Egypt and Syria as a defensive move. They viewed them as expansionist. The U.S. believed that the goals of the U.S.S.R. were to replace Western influence in the region with Moscow's, threaten vital sea routes, outflank NATO, and gain a stranglehold on Middle Eastern oil, all while "using the Arab-Israeli conflict" as its pre-eminent weapon (Slater, 1990, p. 568).

Instead of re-arming the Egyptian and Syrian armies following the 1967 war against Israel, however, the Soviet Bloc did not provide the offensive weapons that Egypt and Syria were clamoring for (Slater, 1990, p, 572). Soviet leaders felt that peace and negotiations though the Rogers Peace Plan was the best way forward in their effort to become an "equal in the region." Rather than another proxy war in the Middle East, which could have resulted in a direct confrontation with the U.S., Soviet leaders figured that a "political settlement that would recognize, preserve, and legitimize their ongoing presence and role in the Middle East" (Slater, 1990, p. 572) would be the best choice.

Egyptian and Syrian leaders were confused and did not understand why the Soviets did not wish to provide to them the offensive weapons they desired. However, realizing that they operated from a position of weakness, Egyptian leader Anwar Sadat declared (following the advice of the U.S.S.R. and UN intermediary Gunnar Jarring), that if Israel committed itself to the "withdrawal of its armed forces from Sinai and the Gaza 
Strip" as well as the implementation of UN Security Council Resolution 242, Egypt would then "be ready to enter into a peace agreement with Israel" (Israeli Ministry, Section: "Israeli Response", para. 8). However, Israel responded that it would not withdraw to the pre-June 5, 1967 lines. Israeli leaders, operating from a position of strength, were ultimately "unresponsive to Egyptian overtures" peace (Burr, 2003, para. $8)$.

Israel's refusal to engage in serious negotiations with Egypt and Syria combined with the U.S.S.R.'s refusal to provide offensive military equipment, ultimately forced Egypt and Syria to attack Israel in October of 1973. The Soviets had gone as far as leaking Egyptians plans to invade Israel in 1972. Of course, such Soviet actions completely infuriated Egyptian President Anwar Sadat, who went ahead and expelled 20,000 Soviet personnel from Egypt. Sadat and the Egyptian Arabs then develop a new strategy. They surmised that the only way that the Israelis would even negotiate and give them back the Sinai Peninsula was by going to war and provoking the Israelis (really the U.S.) to come to the bargaining table (Jordan, M, 1997, Section: "Background", para. 2).

Though Egypt and Syria did witness some early victories, the tide eventually turned in the favor of Israel. Israel and the U.S. eventually offer, confirming the strategy of Anwar Sadat, the Sinai Peninsula to Egypt in return for peace. In turn, Egypt recognizes the state of Israel and joins the Western orbit and becomes the $2^{\text {nd }}$ largest recipient of U.S. military aid (Wall, 2003, para. 10). Overall, unlike the Soviets in regard to their allies in the region, the U.S./West did not pressure Israel to engage in diplomacy. 


\section{The Horn of Africa}

While losing ground in the Middle East, the Soviet Bloc shifted their focus to other opportunities to weaken U.S. interests in this strategic region, such as in the Horn of Africa. The Horn of Africa was considered very strategic as this was the area in which Western oil tankers traversed. The states in this region (such as Ethiopia, Somalia, Sudan), that flanked the oil-rich states of Arabia, the Bab el Mandeb Straits, the Gulf of Aden, and the Indian Ocean, became the strategic targets of the Soviet Bloc.

To the benefit of the U.S.S.R., the correlation of forces in the Horn of Africa began to change during the late 1960 's. Tired of U.S. favoritism towards Ethiopia, illustrated by the U.S. provision of over $\$ 200$ million in military and economic aid to Ethiopia between 1953 and 1974, the new revolutionary military leadership in Somalia sought to extract the economic value of their strategic location (Schwab, 1978, p. 12). Thus, Somalia allied themselves with the U.S.S.R. in the early 1970's and, in exchange for $\$ 250$ million, the Soviets were provided with port facilities in Berbera overlooking the Red Sea, an air base in Harghessa, and several Naval support communication networks (Schwab, 1978, p. 12). Soviet assistance to the port of Berbera helped improve the capacity for "missile storage for the Soviet navy, an airfield with large runways that were capable of handling large bombers, and extensive communication facilities (Schwab, 1978, p. 17). Other attempts to bolster the Somalis in 1974 included jet fighters, tanks, a missile defense system, and Cuban military advisers.

Another pro-socialist military coup occurred in nearby Ethiopia in 1974. The new revolutionary regime banned the monarchy, eschewed U.S. imperialism, and turned into a Marxist-Leninist party resulting in a major cut of U.S. military and economic assistance. 
Ironically enough, it was Soviet military aid to Somalia that helped create the instability that led to the coup in the first place (Schwab, 1978, p. 18).

Seeking to enhance its power in the region during Détente, believing it could mediate between its two new leftist allies (Somali and Ethiopia), the U.S.S.R. stepped in to fill the "military vacuum by providing over $\$ 385$ in arms, including MIG Jet fighters, T-54 and 55 tanks, and anti-aircraft missiles" to the besieged Ethiopian regime (Schwab, 1978, p. 17). Thus, at first glance it seems as if the Soviets were about to capture two key states in the strategic Horn of Africa.

Failing to understand that aid towards Ethiopia could upset the local balance of power, the Soviet gamble backfired badly. Soviet foreign aid towards Ethiopia ended up tilting the correlation of forces in the area towards the Ethiopians. Thanks to large amounts of Soviet support, as well as over 20,000 Cuban troops, the Ethiopians were able to regain the highly strategic Ogaden province (Zunes, 2002, para. 3) from the Somalis. Nevertheless, Soviet assistance towards Ethiopia forever alienated the Somalis (Zunes, 2002, para. 3).

The souring of relations between Somalia and the Soviet Bloc opened the way for the U.S. to exploit events to its liking. Between "the late 1970's until just before Siad Biarre's overthrow in early 1991, the U.S. sent hundreds of millions of dollars of arms to Somalia in return for the use of military facilities which (ironically enough) had been originally constructed for the Soviets" (Zunes, 2002,para. 5). Thus, rather than expanding its influence in the Horn of Africa, Soviet military aid during Détente towards the Ethiopians only caused a shift in alliances. While they may have gained a stronger ally in the region, their investments in Somalia ended up in the hands of the U.S/West 


\section{Section Conclusion}

Scanning the Middle East and Horn of Africa it is evident the U.S./West improved its balance of power position. While successful in improving its overall position in the Horn of Africa (Ethiopia was much more strategic than Somalia) the Soviet Bloc loses Egypt to the West during the Détente time period. U.S. policymakers, such as Brzezinski, who claim that one of the main reasons for Détente's collapse was Soviet aggression in the Ogaden region, ultimately neglects to address U.S. and Israeli maneuvers in regards to Egypt (Zunes, 2002, para. 4). Egypt was, after all, the U.S.S.R.'s most strategic ally in the region.

However, to better study whether the Soviets were aggressive or defensive in the Middle East I will examine the aid allocations of the Soviet Bloc in comparison with those of the West during the Détente time period. It is not just about scanning to see which superpower made new alliances. It is also about analyzing which superpower, if any, sought to change the balance of power.

\section{Southern Africa}

\section{Section Introduction}

My next examination concerns sub-Saharan Africa. According to U.S. policymakers, the Soviet Bloc, thanks to extensive Cuban support for the MLPA (Popular Movement for the Liberation of Angola) in Angola, was aggressive in this region. They argued that the Soviets were strategically after countries with ports so as to deny the West important shipping routes. 


\section{U.S. and Soviet Competition in Angola}

The U.S.-Soviet competition in Angola began following the collapse of Portuguese hegemony in the region. Initially, three different groups- the tribal based FNLA (The National Liberation Front of Angola), the Maoist UNITA (The National Union for the Total Independence of Angola), and Soviet-backed MPLA were responsible for the revolutionary victory against the Portuguese in 1974. What exactly occurred next is subject to historical interpretation and analysis.

Hawks in the U.S., such as those found within the Heritage Foundation, pointed out that the Alvor Agreement, which called for elections and a coalitional government, collapsed due to the fact that the "MPLA imported 13,000 Cuban troops and Soviet advisors and ousted the other two movements" (Pascoe, 1985, para 8.). Seeking to control strategic ports as well as the vast oil and mineral resources of Luanda in Angola, the MPLA and the U.S.S.R. pushed against reconciliation. According to the Heritage Foundation, policymakers in the U.S. believed that the U.S. had no choice but to protect against future Soviet gains in the area (Pascoe, 1985, para. 11.). The arming of UNITA (through Zaire), support of South Africa, and coordination with China were meant to curtail continued Soviet aggression in the region.

Critics of U.S. foreign policy argue that the coalitional settlement known as the Alvor Agreement collapsed due to U.S. insistence that the Marxist/Soviet-backed MPLA should not be a part of the new government (Hormenku, 2006, para. 11). Most importantly, U.S. critics contend that the Ford administration provided covert aid towards UNITA and the FNLA long before Cuban troops landed. Operation IA provided $\$ 6$ million towards these groups on July $18^{\text {th }}, 1975 \$ 8$ million was allocated several days 
later with an additional \$25 million send out in August (Andrew, 1995, p. 412). These critics also argue that U.S. policy should not have been any surprise considering "U.S. exports (construction and mining equipment) to Angola soared from \$54 million in 1969 to $\$ 166$ million in 1973, a 245\% increase (Hormenku, 2006, para. 8) U.S. businesses simply wanted the most business friendly groups at the policymaking table.

Critics also cite that the US, with the help of China, "coordinated and furnished a joint South African, Zaire, FNLA and UNITA offensive against the MPLA. Such U.S. actions simply emboldened the anti-MPLA opposition (Hormenku, 2006, para. 11). South Africa (attacking from the south) and Zaire (attacking from the North) also became conduits by which the U.S., France, and the UK supplied funds, arms, and troops toward their FNLA [and UNITA] patrons" (Minter, 1994, p. 20). Indeed, Western European countries, the proverbial U.S. allies in the Cold War, provided about $\$ 140$ million to Zaire and about \$240 million to South Africa during the 1976-1980 time period (USDA, 1980, p. 131).

Regardless of who initiated the aggression, which I more thoroughly evaluate in the forthcoming quantitative and archival chapters, it is obvious the Soviets picked up a state with Angola in 1975. Though civil war raged on past 1976, Soviet Bloc and Cuban assistance came a long way towards helping the MPLA gain control over the most strategic parts of Angola. The U.S.S.R. was now in a position to expand its naval power and influence in a region where it traditionally had very little.

\section{Mozambique}

Another revolutionary struggle that resulted in a diplomatic gain for the Soviets in this region occurred in Mozambique. Years of harsh Portuguese and South African 
economic exploitation led to a Marxist-inspired coup in 1974. Believing the U.S. and Western Europe were hostile to their revolution, the Marxists leaders in Mozambique pushed for an alliance with the U.S.S.R.

\section{Section Conclusion}

Are these Soviet diplomatic gains enough to suggest the Soviet Bloc was able to alter the balance of power in the region? U.S. and Western claims of a considerable shift in the balance of power could be exaggerated considering how the U.S. and the West had already developed a large network of alliance partners in the region in the years prior to Detente. All together, the West had managed to secure 17 highly strategic military bases and 10 naval dockyards throughout the continent (Coker, 1982, p. 319).

The Soviets, on the other hand, didn't have much luck penetrating the continent before the 1970's. Despite some considerable investment in Ghana, the Soviets were thrown out in 1966 by a Western-backed group (Bissell, 1978, p. 89). With the Western Alliance states of Italy, France, Belgium, German, and the U.S. holding ground in the continent, only the total collapse of Portuguese control over Angola and Mozambique offered the U.S.S.R. any real hope of penetrating sub-Saharan Africa.

However, to really understand the conflicts in Southern Africa during the 1970's I will study the strategic allocations (as well as timing) of the Soviet Bloc towards the most strategic countries in Africa. Examining strategic allocations in this manner will allow me to ascertain a better picture as to whether or not the Soviets were seeking to make gains in sub-Saharan Africa. 


\section{Latin America}

\section{Section Introduction}

For many years the Soviet Union kept a hands-off approach when it came to Latin America. Once described as geographical fatalism, the Soviets calculated that the U.S. strategic rear fell under the "unchallengeable influence of the U.S." (Nogee et al, 1979, 341) After all, the 1954 invasion to depose democratically elected nationalist Juan Arbenz in Guatemala served to highlight the futility of nationalist/anti-imperialist struggles in Latin America. Deeply embedded economic linkages and a proximate military network of bases, and ports gave Washington a strong hand in Latin America.

After all, Latin America was the U.S.'s strategic rear and the region provided the U.S. a considerable amount of strategic raw materials. Investments by U.S. corporations were considerable in Latin America. For instance, by the start of the 1960's “ U.S. investment in Latin America had already reached about $\$ 6$ billion, compared with direct private investments outside the western hemisphere of only $\$ 4.6$ billion (Immerman, 1981, p. 291). Figures for this same period show that about "35 percent of United States imports (valued at approximately \$2.9 billion) came from Latin America” (Immerman, 1981, p. 291) Thus, U.S. planners were keen on protecting American interests in Latin America.

Geographical fatalism on the part of the Soviets, however, had all but faded by the early 1970's. James Cochrane (1989) argues Cuba's survival and a larger array of communist parties throughout the region all but shifted the potential for Soviet Bloc gains in Latin America (p. 213). Moreover, severe social discontent in Latin America (especially Central America) against the economic policies imposed by the Colossus to 
the North posed significant problems for the U.S. and provided an opening for the Soviets.

\section{The Soviets Lose Chile}

Increased Soviet Bloc penetration of Latin America, which began with Cuba in 1959, expanded to Chile in 1970, several years before Détente's implementation. Unlike others on the left, the socialists in Chile decided they could take power through democratic elections. Developing a political platform that blamed Chile's "poverty and inflation on its intimate economic ties with the U.S," the Socialists led by Salvador Allende were able to take the Presidency, many local councils, and gained considerable ground in Congress by 1970 (Nogee, 1979, p. 339).

Allende's victory immediately brought Soviet support. From 1971-1973 it is estimated that the Soviet Bloc funneled in $\$ 363$ million of worth of aid (Nogee, 1979, p. 354). Additional credits for Soviet Bloc machinery and assistance for the construction of a basic oils plant, housing, and chemical plants sealed Moscow's ties to Chile (Nogee, 1979, p. 354). Though Chile eventually rises to become the U.S.S.R.'s number two Latin American client in economic aid expenditures, Soviet policymakers and scholars pointed out that they would not subsidize the Chilean economy in the same manner that they had done for Cuba. The Soviets fully expected new allies to mostly stand on their own two feet (Nogee, 1979, p. 355).

Planners in the U.S., however, could not stomach increased Soviet influence in Latin America. The CIA engaged in funneling money to civilian sectors (destabilization campaign) that would help undertake a 1973 coup against the Soviet-backed Allende government. For instance, covert aid was sent to an opposition research organization, 
which provided "a steady flow of economic and technical support to opposition parties and private sector groups" (Petras et al, 1978, p. 216). The CIA also "funded various political organizations that acted as conduits for funneling money to [copper] strikers," strikers that cost the Chilean economy over $\$ 80$ million in 1973 (Petras et al, 1978, p. 216). The CIA also worked to "foster coup plotters within the Chilean military through deception operations (Kornbluh, 2000, Section: “A Critique”, bullet 3). Overall, documents within the National Security Archive (Project FUBELT) contend that the CIA, if not directly responsible for the coup, undertook operations (collecting coup-arrest lists, pointing out key government installations which needed to be taken over, and prepared propaganda operations) to promote a coup while [economically] undermining Allende's government (Kornbluh, 2000, Section: “A Critique”, bullet 4).

Even before Allende had taken power in 1970, the CIA tried to prevent his coming to power in the elections of 1958 and 1964 (Nogee, 1979, p. 346). A U.S. Senate Report entitled "Alleged Assassination Plots Against Foreign Leaders" also shows that the U.S. used bribery and propaganda techniques during the 1960's as it sought to prevent the coming to power of Salvador Allende (Kornbluh, 2000, Section: "A Critique", bullet 1). With over $\$ 1.7$ billion in U.S. investments and strategic interests at play, Nixon and Kissinger issued National Security Memorandum 93 upon Chile's alliance with the U.S.S.R. Bent on a strategy of "making the Chilean economy scream," the U.S. slashed aid from AID, the Export-Import Bank, World Bank, and the Inter-American Development Bank (Petras et al, 1978, p. 216). The U.S. also pressured private banks to reduce their short-term credits, which seriously affected Chile's capacity to import adequate quantities of essential goods for the day-to-day operation of the system (Petras 
et al, 1978, p. 216). Other policies of economic warfare included the reduction of commercial credits, from $\$ 150$ to 110 million, hurting Chile's ability to buy replacement parts for machinery equipment necessary for its most important sectors (Petras et al, 1978, p. 216).

Despite the aggressive actions on the part of the U.S., there is no evidence that the Soviets attempted to counter the U.S. moves in Chile. Eschewing Cuba's call to the Soviets to get more aggressive in the region, Soviet leaders were under the impression that they could gain more influence throughout Latin American capitals if they would just refrain from covert and aggressive actions. Quite the contrary, it is obvious the peaceful approach did not work out in the case of Chile. All of the political and economic investments the Soviets made were lost.

\section{The Soviets Lose Peru}

Prior to gaining Chile in 1970, however, the Soviet Bloc managed to expand its influence in the region via the gain of Peru in 1969. In fact, the Soviets benefited from General Juan Velasco Alvarado’s socialist-leaning coup against the U.S.-backed Belaunde government. The new Soviet-backed regime nationalized several U.S. holdings (oil, mining companies) and called for a diversification of Peru's foreign trade. In their strategy to acquire air routes in Latin America, sea routes, and expand trade the Soviets offered Peru low lines of credit, generous grace periods, technical assistance, and professional personnel (Berrios et al, 1991, p. 366). The U.S.S.R. and Warsaw countries also offered "assistance for infrastructure projects, solicited a contract on the building of 80 ships for the navy, and provided large arms transfers and the training of army and air 
force personnel" (Berrios et al, 1991, p. 372). On the whole, Peru actually became the second-largest recipient (at the time) of Soviet aid in Latin America.

To the chagrin of the U.S.S.R., General Francisco Morales Bermudez (citing economic mismanagement by the pro-Soviet leaders) of the Peruvian armed forces leads a coup in 1975 and begins to return the country to orthodox [pro-Western] economic management (U.S. Department of State, Section: "Military Rule and the Return to Democracy", para. 2). Bermudez also freezes economic aid with the U.S.S.R., halts Soviet access to Peruvian ports, and pursues an independent foreign policy. Though the U.S. was not directly involved in the coup, the U.S. did pursue informal blockade and did refuse (along with France) to provide military aid on the previously favorable terms to the Soviet-backed Velasco regime (Berrios et al, 1991, p. 368).

Once again the Soviets lose an ally in Latin America during Détente. Once again it can be noted that the Soviets were cautious and non-aggressive. Just as in Chile in 1973, the Soviets did not come to the aid of its Peruvian client in 1975. Should this have occurred in Eastern Europe, you can bet the U.S.S.R. would not have sat idly.

\section{Nicaragua}

The most significant occurrence in the less developed world during the 1970's (in U.S. eyes) was probably the Sandinista Revolution in Nicaragua in 1979. Many factors were in place to propel revolutionary struggles in the region. These included the failures of dependent industrialization, cheap labor strategies, no land reform, no tax reform, massive inequality, high unemployment rates and political repression (Jonas, 1982, p. 125). Once coming to power, the Sandinistas promoted a mixed economy and lobbied the U.S. government for a $\$ 75$ million economic aid package. 
The U.S. did not attack the Sandinistas at first. Liberal internationalists in the U.S., who sought bank repayments, favored a different approach and they won out over the military industrialists. With Carter's human rights stance being wielded against the U.S.S.R., the liberals figured it would be more practical to keep Nicaragua out of the Soviet camp by using economic leverage (aid with strings attached, preserving the role of the business community) rather then engaging in costly U.S. intervention.

Nevertheless, U.S. policymakers still blamed Cuba for helping the Sandinistas rise to power. According to the State Department a series of talks with Fidel Castro and FSLN officials led to the unification of the FSLN, which ultimately allowed the movement to become much more effective (State Department, 1985, Section: "Central America", para. 5). The State Department also argued that these "unification" talks laid the "groundwork for an arms supply network" that began in Cuba, traversed through Panama (via small aircraft), and continued through Costa Rica and on towards Nicaragua (State Department, 1985, Section: "Central America", para. 5). The arms supply network allegedly allowed Cuba to provide Nicaragua with some 1.8-million tons of arms between 1978 and 1979.

A few months after the Sandinistas achieved victory in Nicaragua, the U.S. State Departments also claimed that Cuba and Nicaragua began to spread their anti-American influence throughout Central America (State Department, 1985, Section: "Introduction", para. 2). According to their sources (statements of Sandinista officials and defectors, Salvadoran guerrilla defectors, captured documents, physical evidence, intelligence observations, and other evidence), the State Department argued that the Sandinistas funneled military support towards El Salvadorian rebels (State Department, 1985, 
Section: "Against its Neighbors", para. 1-2). Military assistance towards to El Salvador turned them "a major military force able to mount a nationwide offensive" (State Department, 1985, Section: “Against its Neighbors”, para. 2). The State Department report also contested that the Sandinistas (with the backing of Cuba) "used Costa Rica as a channel for unlawful assistance to the Salvadoran rebels and have [also] supported terrorist actions in Costa Rica" (State Department, 1985, Section: "Against its Neighbors", para. 3).

In response to continued "large-scale" offensive revolutionary aid by Cuba to buttress Nicaraguan support for rebel movements in El Salvador and Guatemala, the U.S. became aggressive and began to block Nicaraguan loans from the Inter-American bank, beefed up military aid towards Nicaragua's right-wing neighbors, and began to organize the counter-revolutionary groups that would eventually push for civil war in Nicaragua and El Salvador (Stokes, 2003, para. 8). Overall, U.S. policymakers claimed that negotiating with the Sandinistas was simply impossible as the "ideological" regime was bent on turning toward the Communist bloc.

Unlike the cases of Chile and Peru, in which the Soviets simply sat by, U.S. aggression against Nicaragua prompted the Soviets to move in and secure their alliances. Starting in 1981 (two years after the Sandinistas take power), the Soviet Bloc finally signed an extensive military aid package with Nicaragua worth $\$ 28$ million, which increased every year from there on (Duncan, 1984, p. 167). The Soviet Bloc also equipped Cuba to become one of the largest and best equipped national armies in the region in the early 1980 's. For instance, the Soviets increased their economic and military aid to the Cubans from $\$ 3.6$ billion to 4.9 billion in 1982 (Duncan, 1984, p. 168). Further 
steps to secure the Nicaraguan regime included the intelligence support of several thousand Cuban advisors.

All in all, the Soviets gained Nicaragua as an ally. Though this "officially" occurred in the early 1980's, and not during Détente, it is possible to suggest that Cuban organizational assistance laid the groundwork for the initial Sandinista victory. Many U.S. policymakers and analysts also believe that the Sandinista victory in 1979 already meant that the Soviets had made a significant gain. In their view, the Sandinistas were determined to shift Nicaragua's allegiance to the Soviet Bloc. To better understand whether the Soviets intended to make a push for Nicaragua, I shall have to analyze the quantitative data and the U.S. archives.

\section{Grenada}

Another gain for the U.S.S.R. and its allies occurred in the Caribbean island of Grenada. Pointing to U.S. dependency and unequal economic exchange, the New Jewel Movement (NJM) galvanized public support for a fairer economy and undertook a revolutionary coup in 1979. Viewing the arrival of Bishop in Grenada as a strategic opportunity to turn the tide against U.S. hegemony in the region, Cuba and the U.S.S.R. stepped in to stabilize the regime. In fact, as quickly as the regime had taken office, Cuba helped "destroy the old army infrastructure and instituted a new people's army, donated countless fishing vessels, and helped improve the island's electrical grid" (Duncan, 1984, p. 169).

The Soviets and their Cuban allies also began to provide several million dollars in economic aid, loans, and manpower towards the building of an airport and a state-of-theart seaport. Such Soviet/Cuban actions struck fears among many in U.S. circles. A new 
international airport/seaport expanded the range and abilities of the Soviet/Cuban air forces and navies within the Caribbean.

\section{Section Conclusion}

Superpower competition in Latin America during the Détente period led to two Soviet Bloc political gains (Nicaragua, Grenada) and two Soviet Bloc defeats (Chile, Peru). Thus, on the surface the balance of power sheet seems to be even. However, a deeper look suggests that this was not the case. Chile and Peru were simply more economically significant for the U.S. and the Soviets than Nicaragua and Grenada. For instance, Chile’s GDP per capita in 1973 was \$5,028 while Nicaragua’s Grenada’s GDP per capita in the low hundreds (NationMaster, para. 5). Chile and Peru also possessed more strategic raw materials than Grenada or Nicaragua.

Perhaps U.S. claims draw on the fact that the Soviet navy's strategic positioning may have improved with the Nicaraguan and Grenadian gains? Regardless, in my attempt to examine why the U.S. claims the Soviet Bloc was expansionist, I will rely on comparing Soviet Bloc foreign aid allocations to those of the West (especially the U.S.).

Only through measuring the strategic aid allocations, as well analyzing the U.S. archives in chapters four and five, can I really get to the heart of the matter. Analyzing the quantitative data and the U.S. archives will also give me the opportunity to determine whether the Soviets made a push for Nicaragua during the final years of Détente.

\section{The Buffer Zone}

The final blow to Détente occurred with the Soviet invasion of Afghanistan in 1979. Beginning on December 27, 1979, "under cover of an ongoing Soviet military buildup, heavily-armed elements of a Soviet airborne brigade were airlifted into Kabul, 
Afghanistan" in an attempt to "violently overthrow the regime of President Hafizollah Amin" (Phillips, 1984, para 2.) Thus, the Soviets were on the verge of pushing their influence to within striking range of the West's Middle East.

Despite traditional Soviet influence over this part of the world, which the U.S. itself was comfortable with so long as Afghanistan maintained internal autonomy, the Soviet intervention in late 1979 brought U.S. condemnation (Gibbs, 1987, 369). Policymakers and hawks in the U.S. argued that the U.S. had to halt "the southern expansion of the Soviet Empire and prevent Moscow from establishing a land bridge to the Persian Gulf' in order to deter the Soviets from trying to choke the West's oil supply (Phillips, 1984, para. 2). They also suggested that the Soviet invasion increased its leverage over Iran, Pakistan, and India. It was obvious that Western Alliance partners (such as France and Britain) thought so also. Their military aid towards Pakistan significantly increased from 41 million per year between 1967 and 1976 (415 million total) to 104 million per year (520 million total) between 1976 and 1980 (USDA, 19671976, p. 68, and USDA, 1975-1979, page 128).

On the other hand, some suggest that increasing Islamic fundamentalism within the Soviet empire's borders together with a newly installed hostile and anti-Soviet leadership in Iran meant that the Soviet Bloc was actually defensive in this part of the world. President Carter's own Secretary of State Vance argued that the Soviets had invaded because they had "a dangerous problem" on their border (Lafeber, 2006, p. 317). Moreover, the history of Soviet economic aid towards Afghanistan seems to underscore the historical importance of Afghanistan as a Soviet sphere of influence. According to Quintin Bach, the Soviets actually pumped in about $5 \%$ of all their economic aid to the 
less developed world during the Cold War into Afghanistan (Bach, 2003, Appendix VI).

Only Mongolia, Cuba, Vietnam, and India received more economic aid.

\section{Section Conclusion}

Soviet intervention, however benign in its attempt to secure its own borders, did expand the Soviet military presence in Central Asia, thus legitimizing U.S. fears of Soviet penetration into the West's most vital sphere of influence (the Middle East). However, as I shall do with all the other regions, to better understand whether such a move was aggressive (as there are competing viewpoints) I shall look at historical factors, the timing of aid allocation, and the strategic foreign aid allocations of the Soviet Bloc to better determine whether the Soviets were striving to alter the balance of power.

Conclusion

\section{Western Dominance Prevails}

The lack of Soviet gains in the less developed world during Détente, at a time when the "tide" was supposedly turning in the Soviet Bloc's favor, suggests that I should take into consideration the overwhelming strategic power the U.S. possessed following World War II. Indeed, the historical evidence suggests U.S./Western power was ample enough for the U.S. to absorb the military expansion of the Soviet Bloc. U.S./Western military and economic power, combined with significant amount of proxies/allies the U.S./West had secured in the less developed, proved to be a potent shield against Soviet advances in the less developed world.

\section{Soviets Quantitative Gains and Loses during Detente}

Now that I have dissected U.S.-Soviet /Western-Soviet Bloc competition in the less developed world during Détente, I should lay out all of the gains and defeats 
experienced by the Soviets between 1972 and 1980. Considering SALT I was the hallmark that characterized the fundamental relaxation of tensions between the U.S. and the Soviet Union (Détente), the date in which both the nuclear and the territorial balance of powers were to be carved out, then it surely makes sense to analyze only those gains and losses that happened after this date. Some may suggest that I should include such Soviet gains as Peru in 1968, Sudan in 1968, Bolivia in 1969, South Yemen in 1970 and Chile in 1970 as well as Soviet losses such as Sudan in 1971, Bolivia in 1971, and Mali in 1968 in order to attain a truer picture measuring the shift in the balance of forces. My project rejects this on the fact that these gains and losses never affected the signing and implementation of Détente.

Overall, there were quantitatively eight Soviet gains (Table 1) between 1972-80, which include the cases of Grenada in 1979, Nicaragua in 1979, Afghanistan in1979, Angola in 1975, Ethiopia in 1977, Vietnam in 1973, Laos in 1975, and Mozambique in 1975. There were five Soviet loses (Table 1), which include Egypt in 1976, Somalia in 1978, Chile in 1973, China in 1977(in Indochina) and Peru in 1975. Ted Hopf (1994) goes on to suggest that there were other Soviet loses, such as Zaire in 1978 and Zimbabwe in 1980 (p. 219). My analysis excludes these two latter cases considering that Zaire and Zimbabwe tended to have very cool relations with the Soviet Union, with the constant expelling of Soviet diplomats and very little economic aid ever provided by the Soviets. Moreover, Mobutu (Zaire) and Ian Smith (Zimbabwe) constantly played the Soviets against the Americans and the Chinese, to the point where they were actively fighting against the MPLA in Angola, a crucial Soviet ally. 
Thus, the historical record and the balance of power sheet points to a more moderate picture of Soviet gains in the less developed world during Détente than that stressed by many U.S. policymakers at the time. The characterization of an aggressive Soviet Bloc seeking to push against Western interests in the less developed world comes across (at least preliminarily) as a myopic account of US-Soviet competition during Détente. The gains for the Soviet Bloc in Asia, the Middle East, and Latin America were offset by the rise of the Sino-Soviet split, the loss of Egypt in the Middle East, and the parting of several allies in Latin America (all without much of a fight). Besides and Angola and Afghanistan, which some dismiss as a defensive Soviet move, the Soviets do not seem to have been aggressive in the most vital areas of the world.

Nevertheless, measuring Soviet aggression and pressure against the balance of power does not just revolve around tallying up Soviet gains and loses. After all, some scholars could suggest that my historical analysis is biased. This is why I now move to analyze the hard-core quantitative and archival evidence. It is simply more significant and important for me to study the foreign aid allocations (especially military) of the Soviet Bloc towards the less developed world. Examining foreign aid allocations actually allows me to understand what the Soviets were actually trying to do. Was Soviet aid massive? Did they send significant foreign aid to areas of vital concern to the West? This quantitative analysis is what I do in chapter three. In addition, it would be very significant for me to actually analyze the perception of U.S. policymakers regarding Soviet and U.S. actions during Détente. U.S. intelligence archives, which I analyze in Chapters four and five, should provide for me a wealth of material in this domain. 
Table 1.

Soviet Gains and Losses

Gains Losses

Vietnam $1973 \quad$ Chile 1973

Laos 1975 Peru 1975

Mozambique $1975 \quad$ Egypt 1976

Angola $1975 \quad$ China 1977 (in Indochina)

Ethiopia $1977 \quad$ Somalia 1978

Afghanistan 1979

Nicaragua 1979

Grenada 1979 


\section{REFERENCES}

Allison, R., Williams, P. (1990) Superpower Competition and Crisis Prevention in the Third World. Cambridge University Press.

Andrew, C. (1995). For the President's Eyes. Harper Collins

Bach, Q. (2003). Soviet Aid to the Third World. Book Guild

Berrios, R., Blasier, C. (1991) "Peru and the Soviet Union (1969-1989)." Journal of Latin American Studies. Vol. 23, pp 365-384.

Bissell, R. (1978) “Testing Détente.” Proceedings of the Academy of Political Science. Vol. 33, pp. 88-98

Burr, W. (2003). "The October War and U.S. Policy.” National Security Archives. Retrieved December 2006 from http://www.gwu.edu/ nsarchiv/NSAEBB/NSAEBB98/

Cochrane, J. (1989). "Contending Perspectives on the Soviet Union in Latin America." Latin American Research Review, Vol. 24, pp. 211-223

Coker, C. “The Western Alliance and Africa.” African Affairs. Vol. 81, pp. 319-335

Duncan, Raymond. (1984). "Soviet Interests in Latin America." Journal of InterAmerican Studies. Vol. 26, pp. 163-198

Dunn, John. (1960). "American Dependence on Materials Imports the World-Wide Resource Base.” The Journal of Conflict Resolution. Vol. 4, pp. 106-122

Halliday, F. (1996). The Making of the Second Cold War. Verso

Holmes, K. (1986) “The Conventional Arms Balance.” Heritage Foundation. Backgrounder \# 489. Retrieved December 2005 from http://www.heritage.org/Research/RussiaandEurasia/bg489.cfm

Hopf, T. (1994). Peripheral Visions. University of Michigan Press

Hormenku, T. (2006). “U.S. Intervention in Africa.” Third World Network. Retrieved July 2006 from: http://www.twnside.org.sg/title/tett-cn.htm

Immerman, Richard. (1981) The CIA in Guatemala. University of Texas Press.

Fu, Gu Guan. (1983) “Soviet Aid to the Third World." Soviet Studies. Vol. 35, pp. 71-89

Gaddis, J. (2005) Strategies of Containment. Oxford University Press 
Gibbs, D. (1987) “Does the USSR Have a Grand Strategy.” Journal of Peace Research. Vol. 24, pp. 365-379

Israeli Ministry of Foreign Affairs. (1971). "The Jarring Initiative and the Response." Retrieved June 2005 from

http://www.mfa.gov.il/MFA/Foreign\%20Relations/Israels\%20Foreign \%20Relations\%20 since $\% 201947 / 1947$ -

1974/28\%20The\%20Jarring\%20initiative\%20and\%20the\%20response-\%208\%20Febr

Jonas, S. (1982). “Central America as a Theater of U.S. Cold War Politics.” Latin American Perspectives. Vol. 9, pp. 123-128

Jordan, M. (1997). “The 1973 Arab-Israeli War: Arab Policies, Strategies, and Campaigns." Retrieved June 2006 from

http://www.globalsecurity.org/military/library/report/1997/Jordan.htm

Keleman, P. (1984). "Soviet Strategy in Southeast Asia.” Asian Survey, pp. 320-333

Kennan, G. (1947). “The Long Telegram.” Retrieved October 2005 from http://www.mtholyoke.edu/acad/intrel/longtel.html

Kennan, G. (1946). "The Sources of Soviet Conduct.” Retrieved October 2005 from http://www.foreignaffairs.org/19470701 faessay25403/x/the-sources-of-sovietconduct.html

Kornbluh, P. (2000) "History Held Hostage." Chile Documentation Project. National Security Archives. Retrieved September 2005 from

http://www.gwu.edu/ nsarchiv/news/20000817/index.html

Kurus, Bilson. (1993). “Understanding ASEAN.” Asian Survey. Vol. 33, pp. 819-831

Lafeber, Walter. (2006) America, Russia, and the Cold War. Mc-Graw Hill

Leffler, M.(1992) A Preponderance of Power. Stanford University Press

Library of Congress. (1987). “The Soviet Union.” Vietnam Country Studies. Retrieved June 2006 from http://countrystudies.us/vietnam/61.htm

Minter, William. (1994) Apartheid's Contras. Zed Books

NationMaster. "Chile." Retrieved October 2006 from:

http://www.nationmaster.com/country/ci-chile/eco-economy

Ned, L. (1994). We All Lost the Cold War. Princeton University Press 
Nogee, J., Sloan J. (1979) “Allende's Chile and the Soviet Union.” The Journal of Interamerican Studies and World Affairs. Vol.21, pp. 339-368

Nwaubani, E. (2001). The U.S. and Decolonization in West Africa. University of Rochester Press

O’Brien, P.(1982) "European Economic Development." The Economic History Review. Vol. 35, pp. 1-18

Owen. N. , Chandler, D. ,William, R. (2005) "Emergence of Modern Southeast Asia." Singapore University Press.

Pascoe, W. (1995). “Angola Tests the Reagan Doctrine.” Heritage Foundation, Backgrounder \#470. Retrieved June 2005 from http://www.heritage.org/Research/InternationalOrganizations/bg470.cfm

Petras, J., Morley, M. (1978). "On the U.S. and the Overthrow of Allende." Latin American Research Review. Vol. 13, pp. 205-221

Phillips, J. (1984). "U.S. Aid for Afghan Freedom Fighters Overdue.” The Heritage Foundation. Executive Memorandum \#44. Retrieved November 2005 from http://www.heritage.org/Research/MiddleEast/EM44.cfm

Pilger, John. (1997).“The Long and Secret Alliance.” Covert Action Quarterly, pp. 43-62

Schwab, P. (1978). "Cold War on the Horn of Africa.” African Affairs. Vol. 77, pp. 6-20

Slater, J. (1990). “The Superpowers and an Arab-Israeli Political Settlement.” Political Science Quarterly, Vol. 105, pp 557-577

Shroeder, W. (1979) “Assessing Defense Spending.” Heritage Foundation. Backgrounder \# 106, Retrieved December 2005 from http://www.heritage.org/Research/NationalSecurity/bg106.cfm

Stokes, D. (2003). “Counterinsurgency, Coups, and Coercion.” ZNet Magazine Retrieved November 2005 from www.globalpolicy.org/empire/history/2003/0402counterinsurgency.htm Time Magazine. (April 1978) "Can the U.S. Defend Itself?” Retrieved in May 2006 from http://www.time.com/time/printout/0,8816,919493,00.html

Trofimenko, H. (1981) "U.S.-Soviet Competition in the Third World.” Foreign Affairs, pp. 1-26

United States Department of State. "Peru Background Notes." Bureau of Western Hemisphere Affairs. Retrieved September 2005 from: http://www.state.gov/r/pa/ei/bgn/35762.htm 
United States Department of State. (1985). "Report on Sandinista Intervention in Central America." Department Bulletin. Retrieved December 2005 from http://findarticles.com/p/articles/mi_m1079/is_v85/ai_3999615

United States Department of State (1981). "Cuba's Renewed Support for Violence in Latin America.” Special Report No. 90., Retrieved September 2005 from http://cubanexile.com/doc_201-225/doc0224.html

United States Disarmament Agency (1967-1976). World Military Expenditures and Arms Transfers. pp. 68-71

United States Disarmament Agency (1975-1979). World Military Expenditures and Arms Transfers. pp. 128-131

United States Disarmament Agency (1976-1980). World Military Expenditures and Arms Transfers. pp. 138-141

Wall, Allen. (2003). "Foreign Aid and the Middle East." GOPUSA. Retrieved June 1007 from http://www.gopusa.com/opinion/aw_1021.shtml

Weatherbee, D. (1978) “U.S. Policy and the Two Southeast Asias.” Asian Survey. Vol. 18 , pp. 408-421

Zunes, S. (2002) "The Long and Hidden History of the U.S. in Somalia." Znet Magazine. Retrieved May 2006 from http://www.hartford-hwp.com/archives/27c/427.html 


\section{Chapter III: Examining Soviet and Western Bloc Foreign Aid to the Less Developed World}

\section{Introduction}

In chapter three I will examine Western and Soviet foreign aid allocations to the less developed world during the years prior to and during Détente. Bringing in the balance of power results from chapter two, which showed a mild to moderate increase in Soviet strategic gains in the least important regions of the world, my overall purpose will be to assess whether the Soviet Bloc attempted to expand its influence. That is, regardless of whether they made gains or losses, which I more succinctly evaluate in chapters four and five, I shall measure whether the Soviets aggressively allocated foreign aid towards traditional and strategic Western spheres of influence undergoing revolutionary turmoil (as argued by many realists) at a time when U.S./Western was (supposedly) decreasing.

Thus, I shall measure the strategic allocation of Soviet aid towards the most strategic countries in each region, the timing of such foreign aid, and other processtracing quantitative factors in assessing whether the Soviet Bloc became aggressive in the Third World during the late 1970 ‘s. As highlighted earlier, I shall scrutinize military aid much more thoroughly considering its immeasurable intrinsic value in helping to alter the balance of power in the less developed world. Of course, in order to extract (through investments) the economic benefits that come from making gains in the less developed world, as well as help cultivate and consolidate allies, the superpowers needed to provide economic aid. Strategic areas of the world such as the Middle East (for the Western Bloc), Latin America (for the U.S.), and the Buffer Zone (for the Western Bloc) will be considered much more important for the maintenance of the U.S.-led Western world 
order than others like Africa and Asia. Chapter three will also analyze Soviet military and economic aid towards its Warsaw Pact allies. Should the U.S.S.R. have decreased aid to Eastern Europe during this time period, while increasing aid to other areas of the less

developed world, it would certainly provide evidence that the U.S.S.R. was neglecting its traditional allies.

My analysis determines whether balance of threat realism or structural Marxism best explains the undercurrents of the final years of Détente. Should I find Soviet foreign aid to have been aggressive, it would suggest balance of threat realists are correct. On the other hand, if I fail to uncover aggressive allocations of Soviet aid, it would lend credence to the arguments laid forth by structural Marxists.

Asia

\section{Section Introduction}

Chapter two highlighted the fact that the U.S.S.R. had managed to make inroads into Asia thanks to revolutionary victories in South Vietnam and Laos. These Soviet gains, however, came at a significant price. As I highlighted in the previous chapter, Soviet gains in Indochina (South Vietnam, Laos) worked in tandem with an about face by the Chinese. Once aligned in their foreign policies with respect to Indochina, the initial Sino-Soviet split spreads even further. Gains by the U.S.S.R. in Southeast Asia also rallied the ASEAN Western-backed elites to band together and pursue policies that in their minds would block the expanding Soviet-backed communist periphery.

To better understand the character of Soviet policy during the final years of Détente it would be prudent to compare Soviet and American military (Soviet bloc versus West) and economic assistance during this time period. Are the Soviets actively working 
to expand their influence in the region as many U.S. policymakers would argue? Was the communist periphery seeking to expand?

Correlating nicely with my findings in the previous chapter, the historical/quantitative data will highlight that the continuation of the Sino-Soviet split brought about severe consequences for the Soviet-backed Indochinese communist periphery. In the face of Chinese military aid cutbacks towards the Communist bloc alliance, I find that military aid towards the communist periphery in Southeast Asia significantly declined during the final years of Détente. The historical analysis also finds that the Western alliance's military aid towards the Western-backed ASEAN Bloc (significant strategic part of Asia) trumped Soviet support towards their allies. These findings suggest the potential for further Soviet gains in Southeast Asia were all but exhausted by the end of the 1970's. My analysis of economic aid also points to a much more defensive Soviet Bloc in Asia than that commonly portrayed.

The Soviet-Sino Split and Western Advantages in Military Aid

Taking into account Chinese military aid during the various periods of Détente, I find that military aid towards the communist periphery did not increase during the final years of Détente. Although the Soviet Bloc allocated about 300 million per year (Table 2) in military aid (most to Vietnam) during the 1967-1976 time period and 400 million per year during final Détente years, such figures do not take into consideration that the Chinese provided substantial assistance towards the communist periphery during the early and middle Détente years. The U.S. Disarmament Agency's WMEAT shows that the Chinese allocated some 1586 million towards Southeast Asia (1300 million to 
Vietnam) between 1967 and 1976, which turns out to be 160 million per year in military aid. The overall Soviet-Chinese assistance to Vietnam was 459 million per year.

Although it seems that the Soviet Bloc has increased its military aid by 100 million dollars during the final years of Détente (Table 2), the overall contributions towards communist allies (the anti-American Bloc) in Southeast Asia actually declined during Détente (from 459 million to 400 million per year) since Chinese assistance dried up by 1977. In fact, Chinese assistance actually turned against Soviet allies in the region as the Chinese aided anti-Soviet clients in Laos and Cambodia while also invading Vietnam in 1979.

The data also show that the West significantly increased military assistance towards its anti-Soviet/anti-communist partners in the region. Compared with the 1967 to 1976 time period, in which the West provided 375 million per year (Table 3) in military aid towards what would become the ASEAN Bloc, the Western allies dramatically increase military aid to 680 million per year towards the ASEAN Bloc by 1975-1979. One way to look at these findings is to argue that the fall of Vietnam mobilized the U.S. and West into a new "containment strategy" in the region. In fact, despite an initial decrease in military aid towards the ASEAN countries at the onset of the creation of ASEAN, Weatherbee's (1978) "U.S. Policy and the Two Southeast Asias" also chronicles significant increases in U.S. military aid (doubling in most of them) between 1974 and 1978 for ASEAN countries (p. 415).

Understanding what exactly the Western allies were containing is quite difficult to answer, however. The data in Table 2 (and Table 3) show that the Communist bloc's military allocations toward their Vietnamese-Cambodia-Laotian allies dropped from 460 
million per year during the middle years of Détente to 400 million per year during the final years of Détente. Western Bloc military aid, however, expanded from 375 to 680 million per year. Thus, it is clear the West was becoming much more active than the Soviets in this region.

Soviet defensiveness in Mongolia and the Economic Aid Advantages of the US

My economic aid/historical analysis also brings to light the defensive character (against the great powers at least) of the Soviet Bloc during the final years of Détente. Increasing competition, as mentioned in chapter two, with China likely forced the U.S.S.R. to spend larger and larger amounts of economic aid on Mongolia (which sometimes exceeded Soviet military assistance to Indochina). Indeed, Bach's figures show that Soviet allocations to Mongolia increased from 68 million per year during the 1965-1969 time period, to 107 million per year between 1970 and 1974, to 380 million per year during the 1975-1979 time period (Table 4).

Nevertheless, several events in the early 1960's, relating to a significant rift in relations between the Soviets and the Chinese, help to explain why Soviet increases in economic aid to Mongolia can be characterized as defensive in nature. These include 1) Increasing efforts by China to "regain" Mongolia as a piece of national territory 2) Soviet aid to India during its war with China and 3) Soviet failure to deliver nuclear weapons to China (Rupen, 1963, pp. 83-84).

The most significant of these was the attempt by China to exercise control over Mongolia. Chinese attempts were met by significant resistance from the Mongolian leadership. In fact, fearing a return to Chinese colonialism the Mongolian leadership moved in 1966 to "sign a treaty of friendship [with the Soviet Union], co-operation and 
mutual assistance, which promised to use all means, including military to safeguard the security and independence of both countries" (Radchenko, 2003, para. 4). In turn, Chinese Communist Party (CCP) Politburo member Liu Shaoqi stated in 1956 "that the Chinese people deeply regret the fact of Mongolia's secession from China and consider Mongolia, like Taiwan, a part of their territory" (Radchenko, 2003, para. 8).

The continued persistence on the part of the Chinese to assert greater control over Mongolia led the U.S.S.R. to dramatically increase their external and internal control over the country during the late 1960 's. The Soviet leadership deployed 52 Soviet divisions along the eastern border of Mongolia (Enkhsaikhan, 1999, Section: "The Soviet Period", para. 3). Significant purges of the military leadership as well as propaganda attacks against Mongolian nationalist hero Ghenghis Khan were also increased by the Soviet leadership during this time period (Rupen, 1963, p. 84).

Such Soviet moves in Mongolia, however, should have been expected, argues Robert Rupen (1963), especially considering Japanese aggression in Central Asia during the 1940's also led to increased Soviet control of Mongolia (p. 84). The Soviets simply regarded Mongolia as a buffer against foreign aggression. It should be no surprise then that increased Chinese determination to gain leverage in Central Asia moved Moscow to send most of its economic assistance in the region towards Mongolia.

If I accept that Soviet economic aid was defensive in nature and entirely eliminate it from my analysis, I would discover that Soviet economic assistance towards the rest Asia was very small and non-changing throughout the 1970's (Table 5). Stable payments over the decades to Asia were stable and not aggressive in any way. On the other hand, Table 5 actually shows the significant economic aid advantage the U.S. possessed over 
the U.S.S.R. in the entire region of Asia. More than that, the U.S. actually significantly increased its economic assistance to the most strategic parts of Asia (Weatherbee, 1978, p. 415).

\section{Section Conclusion}

The historical quantitative foreign aid analysis, as I found in chapter two, points to a more defensive Soviet Bloc in Asia (during Détente) than that commonly depicted by U.S. policymakers. As I showed in the previous chapter, the consolidation of Vietnam into one country, the invasion of Laos, and the partial takeover of Cambodia certainly did lead to important diplomatic, economic, and military gains for the Soviet Bloc. However, there are several reasons why such gains came back to haunt the U.S.S.R. For one, China was no longer a reliable Soviet ally in the region. As shown in chapter two, the Chinese were now determined to aid anti-Soviet movements in the region. Soviet gains/revolutionary movements in Southeast Asia also rallied the ASEAN Westernbacked elites to block the expanding Soviet-backed communist dominoes. The quantitative data demonstrated that the Western Bloc outpaced the Soviet Bloc in military assistance to the region, especially to the ASEAN countries.

Secondly, Soviet economic assistance toward the region during the final years of Détente was also much less than that of the US. Once I take into consideration that the Soviets had become very defensive (due to the Sino-Soviet split) in Mongolia (their historical buffer), I find that the West significantly increased their economic aid towards the enhancement of ASEAN in manner that was much more aggressive than the Soviets in Asia. Thus, I find the West having aggressive intentions in the region and not the 
Soviets. However, I shall dig deeper and analyze the archives in the next two chapters in order to obtain a better picture of Soviet actions in Asia.

The aggressive allocations of foreign aid by the U.S./West towards ASEAN, coupled with Soviet defensiveness in the region, strengthen the arguments laid forth by structural Marxists and weaken those made by balance of threat realists. The evidence does not show the Soviets upping the ante in the least. Of course, I must consider the rest of the regional evidence before arriving at a final conclusion.

\section{Middle East}

\section{Section Introduction}

My analysis of the balance of power in chapter two demonstrated that the Soviet Bloc lost ground in the Middle East region during Détente. The Soviets may have gained Ethiopia as an ally, but they lost Somalia and Egypt to the U.S./Western camp. Chapter three strengthens these findings and shows that the West not only improved its balance of power standing in the region at the onset of Détente, but they were also the more aggressive superpower bloc when it came to the distribution of strategic foreign aid. The West's military aid to the most strategic countries of the Middle East outpaced Soviet foreign aid. On the other hand, Soviet foreign aid allocations were not even strategic at times and seemed to have been allocated for economic reasons. The Soviet Bloc's failure to provide economic aid towards Ethiopia and their significant arms packages for Libya, which were located in the extreme periphery of the region, convinces me that the U.S.S.R.'s primary motivations (at times) in this region may have been to sell military arms. 


\section{Western Aggression in Military and Economic Aid}

My historical/quantitative analysis finds that the Soviet Bloc was aggressive in this region in the years prior to Détente (thus the Egyptian gain). Soviet military aid to the region between 1964 and 1973 (Table 6) surpassed Western military aid by a margin of 412 to 301 million per year. The U.S.S.R. also overtook the U.S. in economic aid allocations between 1965 and 1969 (Table 7).

As I look into the Détente period, however, I find that Western foreign aid completely outpaced Soviet assistance to the region. Western allocations of military aid increased from 301 million per year in the 1964-1973 to 840, 4096, 3920, and 3690 million per year during the 1967-1976, 1973-1977, 1974-1978, and 1975-1979 time periods (Table 6). The Soviets were simply not able to match these increases as their military aid allocations were 412, 658, 1588, and 2128, 2496 million per year during the same respective time periods (Table 6). The same pattern emerges within the economic aid arena as U.S. economic aid outpaces Soviet economic assistance to the region (Table 7).

The picture becomes even clearer once I go ahead and analyze the military aid allocations made by the West and the Soviet Bloc towards their most strategic allies in the region. The most important countries of the Middle East (remember I am excluding the Buffer Zone) are Israel, Saudi Arabia, Egypt, Syria, UAE, Kuwait, Yemen Aden, and Yemen Sanaa. Together, these countries form a triangle around the most important natural resources of the Persian Gulf. From oil and natural gas to the transportation systems they depend on, these countries are prized possessions for hegemonic powers. By studying foreign aid allocations (especially military) to these countries, on the part of the 
West and the Soviet Bloc, I will better understand what exactly was occurring during the final years of Détente in the Middle East.

My analysis of military aid allocations towards the most strategic countries of the region (Table 8) suggests the West came out much stronger at the end of Détente than it was heading into it. The West's military aid contribution towards its most strategic clients during the final years of Détente was 1780 million per year. Conversely, Soviet Bloc military aid towards the most strategic parts of the Middle East totaled 1060 million per year. This pattern of Soviet-Western assistance was all in sharp contrast to the 1967-1976 time period in which the West's most strategic allies received 470 and Soviet strategic allies received 510 million per year in military aid. In fact, Table 8 shows that Soviet military aid towards the most strategic countries of the Middle East only slightly increased while Western military aid skyrocketed.

The increasing militarization of U.S. policy is also very apparent when specifically analyzing the increased U.S./Western military support towards its closest allies. Indeed, Table 9 shows Israel, Saudi Arabia, and Kuwait receiving 3-10 times more military assistance at the end of Détente than at its start.

Relating to gains and losses, analyzing military aid highlights the fact that Egypt's allegiance was now being shifted over to the Western Bloc. Indeed, Soviet military aid towards Egypt plummets to about 120 million per year during the later years of Détente (Table 10). On the other hand, Table 11 shows in clear-cut fashion just how much Western assistance to Egypt during this time period significantly increased.

The U.S. was also providing much more economic aid (Table 13) towards the most strategic countries in the region during the final years of Détente than the Soviet 
Bloc. The U.S. allocated some 1160 million per year towards its strategic allies while the Soviet Bloc allocated 124 million per year. It is simply quite obvious that the tide had turned in the U.S.'s favor when examining the economic allocations of the preceding 1969-1974 time periods. These early Détente years saw the Soviet Bloc possess a 106 to 58 million per year advantage. As a result, the U.S. seems much more determined in seeking to consolidate its allies in the region during the final years of Détente than the U.S.S.R. Soviet economic aid allocations, on the other hand, remained relatively the unchanged (Table 13).

\section{Was Soviet Foreign Aid even Strategic?}

There is some question as to whether Soviet foreign aid towards the Middle East was even allocated in a strategic manner. For instance, while Libya is certainly strategic and possesses oil, the fact of the matter is that Libya lies in the extreme periphery of this region. The ability of Libya's leaders to influence events in the heart of the Middle East is questionable. If altering the balance of power had been the U.S.S.R.'s primary concern they should have shifted most or all of Libya's military aid towards Syria and Egypt (providing them the offensive weapons they desperately desired at the time). Instead, the Soviet Bloc drastically increased military assistance towards Libya during Détente. The Soviets practically quintupled (Table 10) their already large amounts of military assistance towards Libya from 180 million per year between 1967 and 1976 to about 1000 million per year during the latter years of Détente (1975-1979). In contrast, Soviet assistance to Egypt dried out and its military aid to Syria increased at a much slower rate during Détente (Table 10). 
Some scholars, such as Menon (1982) and Laird (1984) suggest the Soviets were more interested in selling weapons than in expanding its geopolitical interests. How else can I explain why Soviet military assistance towards Libya quintupled while its assistance towards a more strategic Syria only quadrupled? One answer may lie in the fact that Libya was more willing to buy military hardware with hard cash (Menon, 1982, 381). Additional research by Laird (1984) shows that the U.S.S.R. shifted its 1950-1960 policy of providing arms to the developing world on a friendly 10-year credit basis to requiring hard cash payments from 65\% of its customers by 1971 (p.192).

The strategic Horn of Africa is another example. For starters, there is simply no comparison here between Soviet and Western military aid allocations (Table 12). In contrast to the 1967-1976 time period, in which the Soviets had a 25 to 17 million per year advantage, there is simply a huge disparity in favor of the U.S.S.R. that emerges during the final years of Détente. Nonetheless, as in other cases throughout the less developed world, the Soviet Bloc did not provide the necessary economic support to bolster their newfound ally in the region. Considering the U.S.S.R. only allocated 5 million (a negligent amount) towards Ethiopia between 1975-1979, while providing over 1500 million in military assistance (Table 12) it could be once again that economic interests (selling weapons) were much more important in the calculations of Soviet policymakers than long range strategic interests. In fact, Colin Lawson points out that the Soviets only extended significant amounts of economic aid to Ethiopia in the early 1980 's “once they became convinced of the regime's ability to survive and to transform itself into a system with a vanguard party with intimate administrative, political, and ideological links to the Soviet Bloc" (Lawson, p. 514). 


\section{Section Conclusion}

The historical/quantitative foreign aid evidence suggests the U.S./West were the primary aggressors in the Middle East during the Détente time period. Western claims of Soviet aggressiveness in the Middle East are only substantiated within the decade prior to Détente's initiation. Rather than counter such Soviet moves, the U.S. signs Détente. As witnessed from Henry Kissinger himself, the signing of Détente was supposed to have crystallized the territorial balance of power meaning each superpower would cease from making unilateral moves against another superpower's allies. Going against the spirit of Détente, Washington and their ally Israel maneuver themselves into a better balance of power position than ever before.

Instead, the West also overtakes Soviet foreign aid allocations by a long shot. Both in military aid and economic aid, I find that Soviet foreign aid packages to the Middle East during Détente failed to match the military and economic assistance increases of the West and U.S. Western foreign aid dominance was especially the case in the most strategic areas of the Middle East.

However, I do find that the U.S.S.R.'s foreign aid towards the Horn of Africa trumped Western foreign aid. Nonetheless, the Soviets failed to provide any economic support to help in the consolidation of Ethiopia (in contrast to large economic aid packages by the U.S. towards its allies in the region). The U.S.S.R. also allocated large military aid packages towards Libya. The strategic nature of allocating military aid to a country that was in the periphery of the Middle East is very questionable. Nevertheless, even if I consider Soviet assistance to the Horn of Africa as aggressive, it simply pales in 
comparison (both quantitatively and strategically to Western aid to the most strategic areas (oil triangle) of the Middle East.

Such findings could suggest that the U.S.S.R.'s primary motives in the Middle East during Détente involved the selling of military equipment (its most important export). Why else would the Soviet Bloc allocate 1500 million of military aid towards Ethiopia while only allocating 5 million in economic aid? Why else would the Soviets increase their assistance to Libya to a higher degree than to a more strategic Syria? Moreover, ff Soviet policymakers were developing their policies according to geostrategic considerations they would have been much more cautious in regards to Ethiopia. Chapter two showed just how Soviet aid towards Ethiopia ended up alienating Somalia and costing them a valuable ally (as well as investments in a military port). Overall, these findings parallel nicely with those in chapter two. The loss of Egypt for the Soviet Bloc is matched by decreasing foreign assistance to the region. The Soviets were also very cautious in regard to sending military aid towards Syria and Egypt. The Soviets simply abided by Détente as they did not wish to stir the ire of the U.S. Nonetheless, I shall explore further and analyze the archives in the next two chapters in order to attain a better picture of Soviet actions in the Middle East.

The aggressive allocations of foreign aid by the U.S./West towards the Middle East also strengthen the arguments made by structural Marxists and weaken those made by balance of threat realists. The evidence does not show the Soviet acting aggressive in this region. Of course, I must consider the rest of the regional evidence before arriving at a final conclusion. 


\section{Southern Africa}

\section{Section Introduction}

My chapter two findings showed that the Soviet Bloc gained Angola and Mozambique as allies at the very height of the Détente time period. Even though the U.S.S.R. provided significant military assistance to these states, however, I must look deeper to better understand Soviet intentions in the region. Were the Soviets actively seeking to arm and consolidate new allies in the hope that they would penetrate deeper into Africa for the benefit of the U.S.S.R.? Some scholars doubt these claims. They suggest that Soviet leaders exercised caution in Africa as they did not place much hope on the long-term prospects for advances in the region. After all, the U.S.S.R. only moved into Africa once Portuguese imperialism collapsed.

The historical/quantitative analysis of the foreign aid data corroborates nicely with the caution theory. Soviet economic assistance towards Angola and Mozambique was simply abysmal. There is no evidence that the Soviets were seeking to consolidate their newfound gains in the region. Soviet leaders also did not consider the strategic significance of African countries when allocating military aid. These two historical/quantitative findings suggest the U.S.S.R. may have been more interested in selling arms towards these countries.

\section{Portuguese Imperialism Collapses}

Before analyzing the process-tracing quantitative data, it is important to understand that it was not military or economic aid that turned the tide against the West in Southern Africa, but the internal collapse of the Salazar dictatorship. History shows that the collapse of the fascist administration (ultimately the result of poverty and 
repression) was immensely important in the ability of Cuba and the U.S.S.R. to make inroads in the region. Without a doubt, the new Portuguese rulers (Communist Party) were instrumental in allowing "ships from the Communist nations to dock in Luanda and transfer arms to the MPLA, without which Cuba and the U.S.S.R. could not have been involved to such an extent” (Bissell, 1978, p. 92). This new temporary administration was also important in that it also allowed the "communist" MPLA to monopolize power in the Luanda capital at the expense of UNITA and the FNLA.

The opportunity to extract a gain in Southern Africa was not lost on the Soviets. The Soviet Bloc shipped several hundred tons of light arms in April, May, and June of 1975 (Bissell, 1978, p. 90). A superpower struggle for Southern Africa had now begun.

\section{Economic Aid to Southern Africa}

In sharp distinction with its policies towards Cuba and Eastern Europe, with its massive subsidy allocations, the U.S.S.R. was simply unwilling to allocate large economic aid packages towards the most strategic parts of Sub-Saharan Africa (Table 15). In the end, according to Colin Lawson (1988) the "smaller aid packages which have been made available to Angola and Mozambique, ultimately reflected a rational Soviet calculation of those states' more doubtful long-term prospects" (p. 514).

Nation and Kauppi’s (1984) The Soviet Impact in Africa further suggests that the main failure of Soviet-backed regimes in Africa stems from the unwillingness of the Soviet Bloc to gamble and seriously deliver economic aid to the region (2). In comparison to other regions of the developing world Soviet Bloc economic aid also possessed lower grant elements with tougher loan terms (Lawson, 1988, p. 514). Failing 
to provide the necessary economic assistance, especially towards its new strategic allies, the prospects for consolidation significantly dropped.

Conversely, the U.S. provided ten times more economic assistance towards SubSaharan Africa than did the U.S.S.R. during the final years of Détente (Table 16). Thus, it is obvious the U.S. was much busier consolidating its allies and expanding its influence in the region than the Soviets. After all, as my introduction in the first chapter showed, history has shown that the strength of any superpower lies not only in expanding its military power, but also in expanding unfair trade with the states they exploit.

Soviet experiences in regards to failed economic aid strategies (infrastructure projects) in Africa during the 1950's and 1960's were probably responsible for Soviet retrenchment in economic aid assistance during the Brezhnev years and Détente. The Soviets fathomed economic aid allocations to these countries were "too expensive and the recipients to unreliable to warrant major investments in their loyalty" (Lawson, 1988, p. 505). Soviet leaders also made the decision that economic assistance towards non-CMEA countries would have to factor both the political reliability of the respective vanguard party as well as the likelihood that the recipient state would eventually join (and add significant benefits to) the CMEA economy (Lawson, 1988, p, 506). For these reasons, the Soviets rejected Mozambique's application to join CMEA. As a result, it seems that the states of sub-Saharan Africa were not worthwhile enough for Soviet exploitation. This may have been the case considering that unlike the West, the Soviet Union already produced in their domestic market many of the goods produced in Southern Africa. 


\section{Soviets and Western Bloc Military Aid to Strategic Southern Africa}

Soviet military aid towards the strategic parts of Southern Africa slightly

dominated that sent by the West (Table 14). Looking at the data in timeline fashion, I find that the Soviet Bloc sent 410, 925, and 1090 million towards Mozambique and Angola during the comparable five year spans of 1973-1977, 1974-1978, and 1975-1979 (including Cuban military aid). On the other hand, the sworn enemies (Zaire and South Africa) of Angola and Mozambique received 895, 860, and 775 million during those same comparable five year spans from the West. These facts suggest the Soviets were becoming very aggressive in the region of Southern Africa. Of course, it should be considered that the Western allies already had years of military aid under their belt while Soviet allies were actually facing strong internal enemies.

However, there is also evidence that the Soviet Bloc may have allocated military aid in a non-strategic manner. Robert Grey (1984), in "The Soviet Presence in Africa: An Analysis of its Goal", illustrates the lack of a significant connection between Soviet arms deliveries to sub-Saharan African states with ports (strategic as far as positioning Soviet navy is concerned) and those without ports (p. 517). The Soviets only allotted high amounts of military aid to $15 \%$ of the African states with ports while providing high levels to 7\% of African states without ports (Grey, 1984, p. 517).

Grey (1984) also demonstrates that the overwhelming majority of Soviet military aid was delivered to countries that either would not seek Western military aid or the West itself would not provide it because of the ideological hostility between the new socialist rulers and the capitalist West. He cites that the U.S.S.R. only provided military aid to $16 \%$ of the non-socialist oriented countries of Africa while allocating significant military 
assistance towards the Marxist-Leninist and socialist-oriented states that were now enemies of the West (Grey, 1984, p. 520).

These findings have led some scholars to speculate that the U.S.S.R.'s main goal in sub-Saharan Africa actually involved the selling of arms (and Marxist regimes were willing to buy them), which was one of the U.S.S.R.'s most important exports, and not aggressive strategic calculations. Not only did arms sales account for about $22 \%$ of Soviet export earnings (which was second only to fuel exports by the 1970's) but starting in the 1970's the Soviets did "shift away from a policy of using arms primarily for geopolitical influence towards a policy that also provided economic benefits by requiring hard-currency payments for arms from virtually all its customers (Laird, 1984, p. 197). Prior to 1973 "Soviet arms (to the less developed world) were usually provided on credit at a 2-5\% rate of interest with a 10-12 year amortization period" (Menon, 1982 p. 381). Since then, the Soviets required hard cash from $65 \%$ of their customers (Laird, 1984, p. 197). While these facts alone do not necessarily push the Soviets geostrategic considerations (especially in Angola) to the background, my previous findings on the lack of Soviet economic assistance towards strategic sub-Saharan Africa probably close the deal. They suggest the Soviets were more interested in selling arms to states (and most of them just happened to be anti-Western) that were willing to buy them.

\section{Section Conclusion}

In summary, the Soviet Bloc seems opportunistic and not actively seeking to alter the balance of power in Sub-Saharan Africa considering the historical and process-tracing findings I have discovered. These include: 1) the reality that the Soviet Bloc only moved in to Angola and Mozambique once Portuguese imperialism collapses 2) the total lack of 
economic assistance to the region (overwhelming focus on military aid), 3) the fact that the Soviet Union allocated military aid in a non-strategic manner and 4) the fact that the U.S.S.R. began to require hard currency for its military aid sales.

My findings in this chapter parallel those in the previous chapter. Just as the Soviets did not considerably expand their balance of power score sheet, the Soviets did not expand their foreign aid allocations in a strategic manner. They knew the West was dominant in the region. A large network of military installations (bases and ports) and strong economic linkages through Western institutions kept the Soviets at bay. However, I shall analyze the archives in the next two chapters in order to obtain a better picture of Soviet actions in Latin America.

These findings continue to weaken the arguments made by balance of threat realists and strengthen the arguments made by structural Marxists. The evidence does not show the Soviet acting aggressively in this region. Of course, I must consider the rest of the regional evidence before arriving at a final conclusion.

\section{Latin America}

\section{Section Introduction}

The most severe blow to Détente for some U.S. policymakers was the Soviet penetration of Latin America. Soviet and Cuban military aid/support towards Nicaragua,

Guatemala, and El Salvador was cited by the U.S. as a destabilizing force in the region. If it were not for Soviet and Cuban support, U.S. policymakers suggested that antiAmerican revolutionary movements in Central America would have been crushed easily by the U.S. Instead, the Sandinistas managed to take control in Nicaragua in 1979 while 
other revolutionary groups threatened to overturn pro-American governments in El Salvador and Guatemala into the 1980s.

In contrast to U.S. suggestions of Soviet aggression, I find that Soviet military aid towards the U.S.'s strategic rear during the final years of Détente (1975-1979) was not very aggressive. Once I take into account that a good portion of Soviet military aid towards Cuba made its way unto Angola (the 1975-1979 time period) and the fact that Cuba did not send much assistance to Central America, it seems the Soviets were quiet disinterested in the region. There is also evidence that the Soviets could barely even control its "subservient" Cuban proxy. Such a finding suggests the Soviets could not be confident that their military assistance towards Cuba would reach any of their desired ends. The U.S.S.R. also did not support the new Sandinista government until two years after Détente's collapse nor was it Nicaragua's primary donor. Finally, there is significant quantitative and historical evidence that a split was emerging within the Western Alliance.

Soviet Foreign Military Aid to Latin America

Quantitative aid figures show that the Soviet Bloc presided over large increases of military aid towards Latin America during Détente (Table 17). The Soviets allocated 31 million per year between 1964 and 1973, 206 million per year between 1973 and 1977, 248 million per year between 1974 and 1978, and 300 million per year between 1975 and 1979 towards Latin America. The West, on the other hand, did increase military aid from 178 million per year between 1964 and 1973 all the way to 596 million per year during the final years of Détente (1975-1979) All in all, the ratios of military aid to Latin 
America shifted from 6 to 1 in favor of the West to just over 2 to 1 by the final years of Détente.

\section{Soviet Foreign Aid to Central America/Caribbean}

To better understand and measure Soviet policy in Latin America, however, one needs to study the Soviet-Cuban connection. The main criticism of Soviet foreign policy towards Latin America by the U.S. revolves around the claim that Cuba (the U.S.S.R.'s Latin American proxy) was busy promoting revolution in Central America. As a result, I should study the strategic allocations of the Soviet bloc to Cuba and compare that with Western allocations towards its strategic allies in Central America. If Soviet allotments to Cuba were higher than in previous time periods and/or more significant, it could suggest the U.S.S.R. was seeking to turn the tide in Latin America. After all, of the Soviet Bloc's 1500 million in military aid towards Latin America between 1975 and 1979, Cuba alone received 50\% of these aid allotments (USDA, p. 128). The U.S. itself admits (CIA, 1986, p. 7) that Soviet Bloc military deliveries to Nicaragua did not begin until several years after Détente's collapse.

According to my initial historical/quantitative analysis, the Soviet Bloc seems aggressive in its foreign aid allocations towards Cuba when compared with Western allocations towards such Central American states as Honduras, Nicaragua, El Salvador, and Guatemala (Table 18). Within the military aid arena (the more strategic aid variable), Soviet Bloc military assistance was 36, 96, 104, and 175 million per year during the 1967-1976, 1973-1977, 1974-1978, and 1975-1979 time periods. Respectively, Western military assistance to Central America adds up to 13, 19, 24, and 32 million per year during those very same time periods. Though it is apparent that the Soviet Bloc's military 
support towards Cuba before Détente (1967-1976) was already three times that of Western aid towards Central America (remember that Western clients already possessed several decades of armaments under their wings), it seems that Soviet Bloc's aid towards Cuba begins to increase during each subsequent time period while Western military aid remained relatively steady.

However, some scholars suggest that Soviet military aid to Cuba and Latin America during Détente was actually intended for the war in Angola. One way of measuring how much military aid Cuba delivered and spent in Angola is to make a correlation between increases in Cuban troop level in Angola with the increases of Soviet military aid to Cuba. If I take the average of Cuban troops in Angola between 1973 and 1977, 1974-1978, and 1975-1979 (about 8, 12, and then 16 thousand troops a year), I find that this conspicuously correlates with Soviet increases of at least 200 million towards Havana between each time period (Kahn, 1987, p. 39).

The evidence of Cuban troop level increases implies that most of the Soviet military aid increased during the 1973-1977 and 1975-1979 time periods can be explained as Soviet aid for Angola. The reduction of (at least) 400 million from the Soviet Bloc to Latin America between 1975 and 1979 means that Soviet military support to Cuba was just 95 million per year (Table 19).

Soviet military aid to Cuba is not as aggressive as aggregate U.S. figures would first indicate. Most importantly, however, is the fact that Soviet military aid towards Cuba during the 1970's was never put in play in Central America. The Cubans sent a large portion of this assistance towards Southern Africa. 
An analysis of Cuban military and civilian aid by Susan Eckstein (1989) entitled "Foreign Aid: Cuban Style" backs this up. Eckstein's study finds that "until the 1980s Cuba offered almost exclusively civilian aid to Latin America, military aid to the Middle East, and a combination of the two to Africa and Indochina" (1989, para. 16). However, by the 1980 's “the civilian component became more important, and the military component less important in Africa, whereas military aid to sympathetic governments in Nicaragua and Grenada and to rebels in El Salvador increased (1989, para 16).

What about the rest of Soviet assistance towards Cuba? Table 19 shows that the Soviets were becoming aggressive in Central America/Caribbean. Soviet Bloc military assistance still jumped much more than Western Bloc assistance during Détente. However, as I mentioned earlier, it is not just about aggregate aid figures. It is also important to measure to see whether Cuba actually allocated significant assistance towards Central America.

My historical findings suggest Cuba did not send any significant amounts of military assistance towards the Sandinista rebels in Nicaragua during the Détente time period. While Cuba did send some financial assistance (helped to create a small arms supply network), it must be understood that the "crucial financial support for the FSLN came from Costa Rica, Panama, and Venezuela" (Prevost, 1990, p. 124). Cuba’s most significant support towards the Nicaraguan Revolution of 1979 was Castro's influence in helping to unify the three anti-Somoza factions.

Organizational support, however, is simply not enough to suggest that Cuba was an aggressive actor in Central America during this time period. Even when the revolutionary potential skyrocketed in January of 1978 with the assassination of 
opposition leader Pedro Chamorro, Cuba "did not greatly increase their level of material support to the Sandinistas" (Prevost, 1990, p. 125) Cuban aggression in Nicaragua had already peaked by 1972 (1960's for the rest of Latin America) as they succumbed to the Soviet line of pursuing the peaceful road to socialism. The U.S.S.R. had used economic incentives to force Cuba to adhere to Détente.

\section{Was Cuba a Soviet Pawn?}

Another important thing to consider is how much was Cuba really a subservient proxy to the Soviet Bloc? Many scholars would tie Cuba to the Soviet bloc by looking at the amount of economic assistance the Soviet bloc allocated towards Cuba during the 1975-1979 time period (Table 20). They would argue that Soviet economic assistance quintupled from 240 between 1970 and 1974 to 1180 million during the comparable fiveyear time span of 1975-1979 (final years of Détente).

Cuban dependence on the U.S.S.R. and Cuban acquiescence to Soviet foreign policy goals, however, rarely went hand in hand. According to the Eckstein (1989), the foreign policy of the two countries most diverged "when Cuba was at the peak of its economic dependence on the superpower for trade in the late 1960s" (para. 19) By the 1970's, they find that while Cuba and the U.S.S.R. did work much more closely, Cuba's dependence on the U.S.S.R. had weaned considering Cuba's overall trade with the West had significantly increased to $41 \%$. Becoming dependent on the Soviet Union again for trade by the 1980s, Cuban-Soviet squabbles in foreign affairs resume once more. These facts lead to questions as to whether Cuba was truly a "mindless proxy" of the Soviet Bloc in Latin America. Such a finding suggests the Soviets could not be confident that their military assistance towards Cuba would reach any of their desired ends. 


\section{After Somoza's Fall}

Some U.S. hawks agree that the Soviets/Cubans did not push for nor cause the Nicaraguan Revolution that ousted the U.S.-backed Somoza government. However, they suggest that the Soviets moved in to shore up its new ally in the 1980's. Although they established diplomatic relations and a working relationship, the evidence suggests the Soviet Bloc did not seek hegemonic control over Nicaragua during the early 1980's.

As far as quantitative evidence goes, Doug Stokes (2003), "In Counterinsurgency, Coups, and Coercion: History and the U.S. Empire in Latin America", finds that Moscow's commitment to Nicaragua during the early 1980's was modest (para 8). He points out (Table 21) that Soviet Bloc aid amounted to only $\$ 605.6$ million by 1984 . On the other hand, extensive aid by Mexico ( $\$ 500$ million in credits given by 1984), Western European countries ( $\$ 282.9$ million), the United Nations (UN) and World Bank provided (\$632.2 million) suggests many other countries and international agencies had attained significant influence over Nicaragua by 1984 (Stokes, 2003, para 8).

Historical evidence also suggests Soviet policy towards Central America and the Caribbean was cautious. The Soviet Bloc simply "refused to underwrite socialist construction in such countries as Jamaica and Nicaragua" (Leogrande, 1982, p. 114 ) There are several reasons for this. First, the Soviet Bloc seemed "unwilling to engage in large-scale support of a regime not totally controlled by pro-Soviet Marxists" (Suchlicki, 1987, p. 31). Experiences in Yugoslavia, as well as Cuba, served to highlight that such regimes "are more apt to pursue policy lines independent of Moscow and are difficult to control" (Suchlicki, 1987 p. 32). Secondly, Moscow feared that such foreign assistance 
would bring about full-scale war between the U.S. and the Soviet Union in a region of the world where the U.S.S.R. was simply not well-positioned to effectively fight in.

\section{The Emerging Split between the US and Western Europe}

Détente sees the West strengthen its strategic relationship with South America. Table 22 shows that the gap between Soviet and Western military assistance widened even further in favor of the West during Détente. This primarily is due to the US adding insult to injury and gaining influence in the country of Peru during the 1975-1979 time periods. Previously the only Soviet ally in the region receiving military assistance, Peru slowly but surely receives more and more of its military assistance from the West (USDA, p. 128). This falls squarely in line with my findings of the previous chapter.

Nonetheless, the military aid figures on South America forces me to question how close the US and the rest of the West were. Table 23 highlights that American influence in Latin America was progressively deteriorating during the Détente time period. Breaking down the data according to respective country, I find that France, Germany, and the UK all began to catch up (and some even surpassed) American military aid to the region. Unlike in Asia and Africa, where the U.S. did cede much influence in the region to European allies (thus making it alright if these nations allocated higher amounts than the U.S. in some instances), the case of South America is especially striking. As Wolf Grabendorff (1985) argues, the "traditional North-South domination pattern" established all of a Latin America as a dominant U.S. sphere of influence (p. 630).

As I pointed out in the first chapter, European nations did become more politically and economically involved in Latin America, specifically South America, during the late 1970's and early 1980’s. Grabendorff points out that "given the strong economic 
performance of some Western European nations during the 1970's and their greater willingness to translate their economic position into a bolder international role, Western Europe became an attractive partner for Latin America" (Grabendorff, 1985, p. 630). Leaders in Brazil, Venezuela, and Argentina began to prefer the Europeans over the American as business partners due to the fact that "Western European states neither had the capacity to exert political (military) pressure nor wanted to exercise moral leadership" (Grabendorff, 1985, p. 630). European nations, unlike the U.S.S.R., also offered the same possibilities in regard to capital, technology, and access to markets.

Center-left political parties also preferred to work with Europe. Recognizing the larger amount of political pluralism encompassed within Western European nations, these non-mainstream political parties in Latin America formed links with churches and trade unions in Europe (Grabendorff, 1985, p. 631). Common interest in a social-democratic model of economic development in their respective nations invariably united these factions.

These findings, combined with the overall lack of an aggressive drive by the Soviets in Latin America, force me to question whether U.S. policymakers were much more concerned with Western European encroachment on U.S. interests in the region. It is obvious the alliance of the Western Bloc was starting to weaken. Western Europe did not back up the U.S. against the Sandinistas in Latin America. Instead, some European countries encouraged the Sandinistas and provided economic support.

\section{Section Conclusion}

My historical/quantitative analysis of Latin America, just like my historical analysis in chapter two, seems to point to a more moderate picture of Soviet actions than 
that described by the U.S. To begin with, it seems that Soviet military aid towards Central America was not destined for revolution in the region. Much of the military support sent by the U.S.S.R. towards Cuba was simply used for proxy warfare in Angola and not Central America. Historical evidence also suggests Cuba did not send much assistance to Central America. Regardless, there is also evidence that the Soviets could barely control Cuba. These aforementioned facts lead me to question how much of a proxy Cuba really was to the Soviets. The U.S.S.R. also did not immediately aid in the consolidation of the Nicaraguan regime considering it allowed many nations to work with Nicaragua. Finally, there is significant quantitative and historical evidence that a split was emerging within the Western Alliance.

These findings piggy-back on those of my previous chapter. The Soviets did not make any gains in the region and they also did not allocate foreign aid in an aggressive manner. Further, Soviet assistance to Nicaragua also occurred very late in the game and even then, it was not much. Still, I shall dig deeper and analyze the archives in order to attain a better picture of Soviet actions in Latin America.

My findings further strengthen the arguments made by structural Marxists and weaken those made by balance of threat realists. The evidence does not show the Soviet acting aggressive in this region. However, as mentioned before, I must consider the rest of the regional evidence before arriving at a final conclusion.

\section{Buffer Zone}

\section{Section Introduction}

The traditional buffer zone of Afghanistan, India, Pakistan, Iran, and Iraq is another reference point in my examination of Soviet foreign aid to the less developed 
world. As I mentioned earlier, this Buffer Zone is especially significant (oil reserves, strategic ports) and should be treated as a region of its own (and not as part of the Middle East) because both the Soviet and Western Blocs possessed vital interests in the region. In fact, many analysts have placed certain buffer states within certain Cold War Blocs, such as Afghanistan within the Soviet camp and Pakistan within the West. Prior to the initiation of Détente, they also state that Iran was a Western-backed state while Iraq was a Soviet-backed state. India, on the other hand, was largely independent although Soviet influence probably was slightly more than the West's.

Chapter two pointed out that the Soviet invasion of Afghanistan raised many eyebrows in Washington. U.S. leaders feared the U.S.S.R. was determined to strike at vital Western security interests in the Persian Gulf. The Soviet invasion was simply the last draw for many U.S. policymakers in regards to dismantling their support for Détente. For instance, the U.S. responded by cutting grain exports to the U.S.S.R., scrapping the SALT II agreements, and boycotting the 1980 Olympic Games. Most significantly however, the U.S. began to aid Islamic fundamentalists against the U.S.S.R. This was rather ironic considering Islamic fundamentalists had just dealt a severe blow to U.S. interests in the region (Iranian Revolution).

Despite the fact that the Soviets invaded Afghanistan in 1979, which at first glance seems like an aggressive move, my analysis of the foreign aid allocations suggests the Soviet Union had no intention to alter the balance of power in this region during the final years of Détente. When comparing the strategic foreign aid allocations of the Western and Soviet Blocs towards the most strategic countries in this region, in this case 
being Pakistan and Afghanistan, I find that the West was much more aggressive with its foreign aid allocations (especially military).

Soviet and Western Bloc Military Aid to the Buffer Zone

To begin with, there is significant historical/quantitative evidence regarding the overall relative equality in military aid allocations of the Soviet Bloc and the West towards the entire strategic Buffer Zone in the time periods prior to and during Détente. According to the U.S. Disarmament Agency's WMEAT (Table 25) the West extended 1960, 4860, 5900, 8250, and 9900 million toward the Buffer Zone during the 1964-1973, 1967-1976, 1973-1977, 1974-1978, and 1975-1979 time periods. On the other hand, the Soviets allocated 1810, 4180, 4340, 5290, and 8020 million during those very same time periods. Western military assistance during these comparable five-years was pretty much on par with Soviet military assistance to the region. Rather than Soviet aggression, these findings suggest continuity was at work. These findings also seem to confirm the claim that this area of the world was strategically significant for both Blocs.

Nevertheless, I should analyze the military aid allocations by the Soviet and Western Blocs to the most strategic part (or most contentious) of the Buffer Zone (Pakistan/Afghanistan) in order to better determine whether or not the Soviets were aggressive. When looking at such aid allocations within the 1974-1978, 1975-1979, and 1976-1980 time periods (Table 24), I find that the West and China (China became a Western ally in the region in the late 1970's) allocated 755, 850, and 1080 million in military aid towards the region (Pakistan) while the Soviet Bloc sent 350, 475, and 460 million in military aid (Pakistan and Afghanistan). These figures make it really difficult to contend that the Soviet Bloc was seeking to expand its influence in this region. 
Western/Chinese military assistance during these comparable five-year time periods ultimately outpaced Soviet Bloc military assistance to the region. Soviet and U.S. Economic Aid to the Buffer Zone

Could U.S. accusations have some merit when including economic aid allocations? Were the Soviets trying to consolidate existing alliances? Breaking down the three time periods, I find that the U.S. and the rest of the G7 (Table 26) provided 5463, 2935, and 3469 million in economic aid to the buffer states during the 1965-1969, 19701974, and19 75-1979 time periods while the Soviet Bloc provided 871, 1058, and 2706 million during those same comparable five-year time periods. At first glance it seems a first that the Soviet Bloc is actually catching up to the West. Perhaps the Soviets are seeking to attain greater influence in this region and/or consolidate existing alliances?

However, once I focus attention on Pakistan and Afghanistan (Table 27), which became the most competitive part of the Buffer Zone, I find that the West allocated 240 per year (2160 million total) in economic aid towards Pakistan between 1972 and 1980 . Of that total, 306 million per year (1530 million total) were allocated during the 19751979 time period. In contrast, the Soviet Bloc provided 78 million per year of economic assistance to Afghanistan and Pakistan during the 1972-1980 time period and 122 million per year between 1975 and 1979. So how exactly is the Soviet Bloc being aggressive in the Pakistan/Afghan region when the West's economic assistance towards its Pakistani ally completely outpaced Soviet economic aid? Quite the contrary, this suggests the Soviets were not as aggressive as the U.S.

Even more significant is the fact that Soviet Bloc economic aid increases towards Afghanistan only jumped from 15 million per year to 51 million per year (Table 28) 
during the 1965-1974 and the 1975-1979 time periods. The majority of Soviet economic aid increases in the Pakistan/Afghanistan part of the Buffer Zone was actually funneled towards Pakistan during the 1975-1979 time periods (Table 28). So how could U.S. policymakers suggest the Soviets were seeking to expand their influence in Afghanistan?

Why do I include the other G7 countries when my methodology suggests Western cooperation may be much less in the economic aid arena? The answer is pretty simple. France, Germany, and the U.K. (in particular) have traditionally worked together with the U.S. to dominate the oil-producing centers of the world. They certainly did not wish for the U.S.S.R. to advance in this part of the world. Unlike in the rest of the Middle East, where the G7 economic aid was minimal (400 million), the rest of the G7 allocated 3261 million between 1975 and 1979 to the buffer states. On the other hand, the Warsaw allies of the U.S.S.R. allocated just 135 million (USDA, 1975-1979).

\section{Section Conclusion}

The process-tracing and quantitative evidence demonstrates that the Soviet Bloc was not aggressive with its foreign aid allocations (especially military) towards the Buffer Zone. Relative equality had long existed in the military sphere between the West and the Soviet Bloc several time periods prior to Détente. Most importantly, the historical/quantitative data highlights that the Western alliance's strategic military aid (as well as economic) allocations towards Pakistan (the West's buffer against the U.S.S.R.'s Afghan ally) trumped Soviet Bloc foreign aid. These findings seem to suggest that the U/S West was aggressive in the Buffer Zone. After all, Soviet actions can be viewed as defensive in nature. The quantitative evidence backs up the theory that the Soviets only 
invaded Afghanistan once the spread of Muslim fundamentalism threatened the territorial integrity of the Soviet Union.

Thus, as argued in my previous chapter by Secretary of State Vance, it seems the Soviets did not possess any ill intentions towards this region. They had no designs to make further gains. Chapter three has followed those findings by showing that the Soviets were not allocating significant foreign assistance to this region during the final years of Détente. Of course, I shall look further into the archival evidence in the next two chapters for a better understanding of the Buffer Zone.

These findings further enhance the arguments made by structural Marxists and weaken those of balance of threat realists. The evidence does not show the Soviets enacting aggressive policies in this region. Quite the contrary, the evidence shows the West aggressively increasing their foreign aid towards Pakistan, which eclipses Soviet aid increases by a considerable margin. As mentioned before, however, I must consider the rest of the regional archival evidence before arriving at a final conclusion.

\section{Eastern Europe}

\section{Section Introduction}

Another way of measuring Soviet motives during the Détente time period is to quantify the amount of military and economic aid the U.S.S.R. allocated towards their traditional Cold War allies, the Warsaw Pact, before and after Detente. If I find that there was a shift in Soviet economic and military aid to this traditionally vital region, then it would be possible to say that the U.S.S.R. was paying less attention to its traditional sphere of influence and perhaps directing its attention and perhaps more to other corners

of the world. In fact, some Western scholars have suggested that increased Soviet 
economic pressure on the Warsaw Pact during Détente means the U.S.S.R. was trying to squeeze its profits from Eastern Europe as it increased foreign aid to other areas of the world.

Evidence suggesting that the U.S.S.R. was withdrawing foreign aid from Eastern Europe does not seem to be at hand. Significant increases in Soviet military assistance towards their traditional Cold War allies during the Détente time period is found in the U.S. Disarmament Agency's own WMEAT. Michael Marrese's (1986) “The CMEA: Cumbersome But Effective Political Economy" further suggests that the U.S.S.R. increased its economic aid (subsidy/credit allocations) to Eastern Europe during Détente (p. 302).

Soviet Military Aid to Eastern Europe

The U.S.'s own figures on Soviet military aid (Table 29) to Eastern Europe shows that Soviet military aid to its traditional allies increased dramatically from 440 million per year between 1964-1973 to 714 million per year between 1967 and 1976. Thus, the Soviets actually increased military aid towards their strategic Cold War allies in the years leading to Détente. The trend continued into the heart of Détente (1973-1977 and 19741977) as Soviet military aid doubled to 1468 and 1566 per year. However, as the final years of Détente (1975-1979) roll in, there seems to be a slight drop in military aid deliveries to 1400 million per year.

Some may take the 1975-1979 drop in military aid as evidence that the U.S.S.R. was shifting Eastern European aid to other corners of the less developed world, but such an argument is simply very weak. Soviet military assistance during the final years of Détente (1975-1979) only dropped by 11\% from the 1974-1978 time periods and was 
twice and three times the level of its military aid packages to Eastern Europe during the 1967-1976 and 1964-1973 time periods (Table 29). Soviet leaders simply did not decrease the most strategic type of foreign aid towards its traditional Cold War allies. Soviet Economic Aid to Eastern Europe

Economic aid deliveries to Eastern Europe (although less significant than military aid), mostly allocated through trade subsidies, would be another way in which to assess Soviet foreign policy during Détente. Subsidies to Eastern Europe primarily involved giving oil and non-fuel raw materials at prices below the world market (they could have obtained higher returns by trading with the West) while also importing Eastern European manufactured goods at prices above the world market price (Marrese, 1986, p. 289). These "implicit" trade subsidies are found to have increased during the middle to latter part of the 1970's (Marresse, 1986, p.302/Table 30). Marrese's baseline calculation shows that Soviet economic assistance between 1974 and 1979 was three times (7283 million per year versus 2485 million per year) that of 1970-1973 (Marresse, 1986, Table 30, p. 302).

There also seems to be little evidence that the Soviet Bloc was abandoning its Eastern European allies as it "increased its use of bilateralism in order to put more selective pressure on East European countries in order to receive more non-market benefits for its subsidies or to reduce the level of subsidization" during Détente (Marresse, 1986, p. 304). Marrese (1986) goes on to suggest that the renegotiation of the Bucharest Price Clause in 1975 (which deteriorated the terms of trade for Eastern Europe), seems to be connected to a general shift in the world market price for oil (p. 305). Such increases meant the U.S.S.R. was not willing to forego the benefits of trading 
oil with the West as world prices had just increased. To soften the blow for the Eastern European countries the U.S.S.R. restructured loan payments while also increasing ruble trade credits. The more strategic countries (such as East Germany) also received more credits.

\section{Section Conclusion}

Thus, evidence of the U.S.S.R. neglecting Eastern Europe is very much lacking. The foreign aid allocations (especially military) by the Soviet Union towards its most significant sphere of influence dramatically increased during Détente. The only evidence cited, such as increased economic pressure on Eastern Europe (in order to possibly use such economic aid in an attempt to gain influence in the less developed world), can be explained by a general shift in the world price of oil.

\section{Conclusion}

Chapter Three has found that the Soviet Bloc was not aggressive in its desire to influence the less developed world. In fact, such an assertion must be seriously moderated. Correlating with my findings in chapter two, I find historical/quantitative evidence to suggest (allotments towards the most strategic allies, timing, character of the foreign aid, etc) that the U.S.S.R. was not seriously aggressive in either Africa, Middle East, Latin America, Asia, or the Buffer Zone. The U.S.S.R. also did not abandon its traditional allies during Détente. Military and economic assistance actually increased to the Eastern Bloc. On the other hand, I do find the U.S. to have been aggressive in some key regions, such as the Middle East, Afghanistan, and Asia.

Within Asia, I found that the West also benefited from the Sino-Soviet split in Indochina. The split changed the balance of power dynamics in Southeast Asia to the 
benefit of the West while also forcing the U.S.S.R. to deal with Chinese-American encirclement. Moreover, fearing the expanding communist threats nearby, the ASEAN Western-elites worked with the Western Alliance to preserve their domestic power positions. Indeed, the Western military assistance towards the ASEAN very much surpassed Soviet assistance towards Vietnam during the final years of Détente. Economic assistance from the U.S. also spiked during the final years of Détente, especially towards ASEAN. Though Soviet aid towards Asia did significantly increase, most of this assistance was funneled towards Mongolia. Once I exclude Soviet assistance to Mongolia, which I characterize as defensive, it is obvious US assistance was much more aggressive than Soviet assistance.

Within the West's most strategically vital area of the world, the Middle East, the Soviet Bloc moved to make gains several decades prior to Détente as it helped tilt the balance of power away from the West by providing foreign aid to and developing such allies as Egypt and Syria. However, not only did the balance of power actually shift more towards the West (chapter two), but I found in this chapter that the U.S./West strengthened its relationships with the most important countries of this region and provided significantly more military and economic aid assistance than the Soviet Bloc.

I have also shown how the Soviet Bloc was not aggressive within the African continent. Despite the much larger strategic military aid allocations towards Angola and Mozambique than that provided by the West, there are important historical/quantitative variables that suggest the U.S.S.R. was not aggressive in this region. First of all, the collapse of the Portuguese imperialists can be traced to the rise of nationalist movements in Angola that sought to end the economic and political repression. The Soviets had no 
hand in this. Secondly, unlike the extensive economic support the Soviet Bloc provided to its Vietnamese ally, they did not come even close towards consolidating its Angolan and Mozambique gains in Africa during Détente. Finally, not only did the Soviets overwhelmingly focus on military aid, but I also found evidence suggesting Soviet military aid towards the rest of sub-Saharan Africa was not allocated in a strategic manner (may have been more interested in simply selling arms).

Latin America was certainly one of the most important regions during the Cold War. As an invariable American sphere of influence and the U.S.'s strategic rear, Soviet involvement brought much alarm from Washington. Still, despite possible Soviet intentions of making gains, as highlighted by their increased aid allocations towards Cuba, the U.S.S.R. did not send military aid towards Central America (via Cuba) until 1981. Most of the increase in Soviet military aid to the region could simply be attributed to Cuban military support for Angola. The Soviets also did not aid in Nicaragua's initial consolidation as they allowed other countries (Mexico, Western Europe) to send considerable amounts of economic aid towards Nicaragua. U.S. unwillingness to work with Nicaragua, in light of the Soviets not getting involved for several years, points to a much different picture of what exactly was going on in Latin America. Perhaps American leaders were more concerned with increased European influence in Latin America after Europe increased its trade links with Latin America during the 1970's and became the dominant provider of military weapons to South America.

My analysis of the strategic Buffer Zone highlighted a non-aggressive Soviet Bloc. The process-tracing data highlights that the Western alliance's strategic foreign aid 
allocations (both military and economic) towards the Pakistan/Afghan region increased much more than that of the Soviet Bloc during Détente.

Finally, the U.S.S.R. did not abandon its allies in Eastern Europe. Military assistance towards Eastern Europe actually increased during Détente. I also found that economic subsidies during the latter years of Détente were much higher than those allocated during the early part of the 1970's.

My findings strengthen the arguments made by structural Marxists and weaken those made by balance of threat realists. The evidence does not support the assertion that the Soviet Bloc was aggressive in the less developed world. Just the opposite, the historical/quantitative evidence points to the West as the aggressive superpower Bloc in the less developed world. Nonetheless, I will now turn to the U.S. archives in order to attain a better picture. If I can uncover the same pattern, of Soviet caution and Western aggression, it would only strengthen my findings. 
Table 2

Communist Bloc Military Aid to Indochina before and after Sino-Soviet Split

\begin{tabular}{lll} 
Years & Soviet-China Bloc & Just Soviet Bloc \\
\hline 1967-1976- pre/Early Détente & 4586 (459 per year) & 3000 (300 per year) \\
1973-1977- Middle Détente & 2150 (430 per year & 1620 (324 per year) \\
$1974-1978$ Middle Détente II & 2075 (415 per year) & $1850(370$ per year $)$ \\
$1975-1979-$ Late Détente & $2000(400$ per year $)$ & $2000(400$ per year $)$ \\
\hline
\end{tabular}

Source: corresponding WMEATs, in Millions

Table 3.

Soviet and Western Bloc Military Aid to Indochina and ASEAN Spheres of Influence

\begin{tabular}{lll}
\hline Years & Soviet Bloc & Western Bloc \\
\hline $1967-1976-$ pre/Early Détente & 3000 (300 per year) & $3750(375$ per year $)$ \\
$1973-1977-$ Middle Détente I & 1580 (316 per year) & 2500 (500 per year) \\
$1974-1978$ - Middle Détente II & 1800 (360 per year) & $3050(610$ per year $)$ \\
$1975-1979$ - Late Détente & 2000 (400 per year $)$ & $3400(680$ per year $)$ \\
\hline
\end{tabular}

Source: corresponding WMEATs, in Millions

Table 4.

Soviet Economic Aid to Mongolia

\begin{tabular}{ll} 
Years & Soviet Union \\
\hline $1965-1969-$ pre-Détente & $340(68$ per year $)$ \\
$1970-1974-$ Early Détente & $535(107$ per year $)$ \\
$1975-1979-$ Late Détente & $1900(380$ per year $)$ \\
\hline
\end{tabular}

Source: Bach (U.S.S.R.), in Millions 
Table 5.

Soviet and US Economic Aid to Asia (Excluding Soviet Aid to Mongolia)

\begin{tabular}{|c|c|c|}
\hline Years & Soviet Union & US \\
\hline 1965-1969-pre Détente & 240 (48 per year) & 4495 (899 per year) \\
\hline 1970-1974-Early Detente & 500 (100 per year) & 5560 (1112 per year) \\
\hline 1975-1979-Late Détente & 670 (134 per year) & 2728 (546 per year) \\
\hline \multicolumn{3}{|c|}{ Source: OECD (U.S.), Bach (U.S.S.R.), in Millions } \\
\hline \multicolumn{3}{|c|}{$\begin{array}{l}\text { Table } 6 . \\
\text { Soviet and Western Bloc Military Aid to Middle East }\end{array}$} \\
\hline Years & Soviet Bloc & West \\
\hline 1964-1973-pre-Détente & 4120 (412 per year) & 3010 (301 per year) \\
\hline 1967-1976-pre/Early Détente & 6580 (658 per year) & 8400 (840 per year) \\
\hline 1973-1977-Middle Détente & 7940 (1588 per year) & 20480 (4096 per year) \\
\hline 1974-1978- Middle Détente II & $10640(2128$ per year $)$ & 19600 (3920 per year) \\
\hline 1975-1979-Late Détente & 12480 (2496 per year) & 18400 (3680 per year) \\
\hline
\end{tabular}

Source: corresponding WMEATs, in Millions

Table 7.

Soviet and US Economic Aid to Middle East

\begin{tabular}{lll}
\hline Years & Soviet Union & US \\
\hline $1970-1974-$ Early Détente & 1022 & 608 \\
$1975-1979-$ Late Détente & 1150 & 4488 \\
\hline
\end{tabular}

Source: OECD (U.S.), Bach (U.S.S.R.), in Millions 
Table 8.

Soviet and Western Bloc Military Aid to Strategic Areas of the Middle East

\begin{tabular}{lll} 
Years & Soviet Bloc & West \\
\hline 1967-1976-pre/Early Détente & $5100(510$ per year $)$ & $4700(470$ per year $)$ \\
$1973-1977-$ Middle Détente I & $3400(680$ per year $)$ & $4755(955$ per year $)$ \\
$1974-1978-$ Middle Détente II & $4100(820$ per year $)$ & $6750(1350$ per year $)$ \\
$1975-1979-$ Late Détente & $5300(1060$ per year $)$ & $8900(1780$ per year $)$ \\
\hline
\end{tabular}

Source: corresponding WMEATs, in Millions (Includes Israel, Saudi Arabia, Egypt, UAE, Kuwait, Yemen Aden, Yemen Sanaa)

Table 9.

Western Military Aid to Israel, Saudi Arabia, Kuwait

\begin{tabular}{llll} 
Years & Israel & Saudi Arabia & Kuwait \\
\hline 1967-1976-pre/Early Détente & 49 per year & 144 per year & 18 per year \\
1973-1977-Middle Détente & 160 per year & 414 per year & 85 per year \\
1974-1978-Late Détente I & 196 per year & 600 per year & 140 per year \\
1975-1979-Late Détente II & 172 per year & 720 per year & 150 per year \\
\hline
\end{tabular}

Source: corresponding WMEAT, in Millions

Table 10.

Soviet Military towards Libya, Syria, Egypt

\begin{tabular}{|c|c|c|c|}
\hline Years & Libya & Syria & Egypt \\
\hline $\begin{array}{l}\text { 1967-1976-pre/Early Détente } \\
\text { per year) }\end{array}$ & 1800 (180 per year) & 2000 (200 per year) & $2400(240$ \\
\hline $\begin{array}{l}\text { 1973-1977- Middle Détente I } \\
\text { year) }\end{array}$ & 2750 (550 per year) & 2150 (430 per year) & $950(190$ per \\
\hline $\begin{array}{l}\text { 1974-1978- Middle Détente II } \\
\text { year) }\end{array}$ & 4100 (820 per year) & 3100 (620 per year) & 750 (150 per \\
\hline $\begin{array}{l}\text { 1975-1979-Late Détente } \\
\text { per year) }\end{array}$ & $5000(1000$ per year & ) 3950 (790 per year) & 600 \\
\hline
\end{tabular}

Source: corresponding WMEATs, in Millions 
Table 11.

Western Military Aid to Egypt

Years West

1967-1976 pre/Early Détente 245 (25 million per year)

1973-1977- Middle Détente $\quad 590$ (118 million per year)

1974-1978- Middle Détente II $\quad 840$ (168 million per year)

1975-1979- Late Détente 1090 (218 million per year)

Source: corresponding WMEATs, in Millions

Table 12.

Soviet and Western Bloc Military Aid to Horn of Africa

\begin{tabular}{llc}
\hline Years & Soviet Bloc & West \\
\hline 1967-1976-pre/Early Détente & 245 (25 per year) & 165 (17 per year) \\
1973-1977 Middle Détente I & 740 (148 per year) & 280 (56 per year) \\
1974-1978 Middle Détente II 1360 (272 per year) & 360 (72 per year) \\
1975-1979-Late Détente & $1730(346$ per year $)$ & $500(100$ per year $)$ \\
\hline
\end{tabular}

Source: corresponding WMEATs, in Millions

Table 13.

Soviet and US Economic Aid to Strategic Areas of Middle East

\begin{tabular}{|c|c|c|}
\hline Years & Soviet Union & US \\
\hline 1969-1974-Early Détente & 635 (106 per year) & 350 (58 per year) \\
\hline 1975-1979-Late Détente & 620 (124 per year) & 5800 (1160 per year) \\
\hline
\end{tabular}

Source: OECD (U.S.), Bach (U.S.S.R.), in Millions 
Table 14.

Soviet and Western Bloc Military Aid to Strategic Areas of Southern Africa

\begin{tabular}{lll}
\hline Years & Soviet Bloc & West \\
\hline 1973-1977-Middle Détente I & 410 & 895 \\
1974-1978-Middle Détente II & $925(200$ from Cuba $)$ & 860 \\
1975-1979-Late Détente & 1090 (400 from Cuba) & 775 \\
\hline
\end{tabular}

Source: corresponding WMEATs, in Millions (Includes Angola and Mozambique for the Soviet Bloc and Zaire and South Africa for the West)-comparable five year time periods

Table 15.

Soviet Economic Aid to Strategic Areas of Southern Africa

\begin{tabular}{ll} 
Years & Soviet Union \\
\hline 1965-1969-pre-Détente & 0 \\
1970-1974-Middle Détente & 0 \\
1975-1979-Late Détente & 31 (15 Angola, 16 Mozambique) \\
\hline
\end{tabular}

Source: Bach in Millions

Table 16.

Soviet and US Economic Aid to Sub-Saharan Africa

\begin{tabular}{lll}
\hline Years & Soviet Union & US \\
\hline 1960-1964-pre-Détente I & 40 & 1807 \\
1965-1969-pre-Détente II & 40 & 1560 \\
$1970-1974-$ Early Détente & 127 & 1150 \\
1975-1979-Late Détente & 247 & 2938 \\
\hline
\end{tabular}

Source: corresponding OECD (U.S.), Bach (U.S.S.R.), in Millions-comparable five year time periods 
Table 17.

Soviet and Western Bloc Military Aid to Latin America

\begin{tabular}{lll}
\hline Years & Soviet Bloc & West \\
\hline 1964-1973-Early Détente & 310 (31 per year) & 1783 (178 per year) \\
$1973-1977-$ Middle Détente & $1030(206$ per year $)$ & 1851 (370 per year) \\
$1974-1978$ - Middle Détente II & $1240(248$ per year $)$ & 2385 (477 per year) \\
$1975-1979-$ Late Détente & $1500(300$ per year $)$ & $2984(596$ per year $)$ \\
\hline
\end{tabular}

Source: corresponding WMEATs, in Millions

Table 18.

Soviet and Western Bloc Military Aid to Strategic Areas of Latin America

\begin{tabular}{lll}
\hline Years & Soviet Bloc & West \\
\hline 1967-1976-pre/Early Détente & $355(36$ per year $)$ & $132(13$ per year $)$ \\
$1973-1977-$ Middle Détente & $480(96$ per year $)$ & $96(19$ per year $)$ \\
$1974-1978$ - Middle Détente II & $620(104$ per year $)$ & $120(24$ per year $)$ \\
$1975-1979-$ Late Détente & $875(175$ per year $)$ & $160(32$ per year $)$ \\
\hline
\end{tabular}

Source: corresponding WMEATs, in Millions (Includes Cuba for the Soviet Bloc and Honduras, Guatemala, Nicaragua, and El Salvador for the West)

Table 19.

Soviet and Western Bloc Military Aid to Strategic Areas of Latin America (Excluding Cuban Aid to Angola)

\begin{tabular}{lll}
\hline Years & Soviet Bloc & West \\
\hline 1967-1976-pre/Early Détente & $355(36$ per year $)$ & $132(13$ per year $)$ \\
1973-1977-Middle Détente & $480(56$ per year $)$ & $96(19$ per year $)$ \\
$1974-1978-$ Middle Détente II & $420(84$ per year $)$ & $120(24$ per year $)$ \\
$1975-1979-$ Late Détente & $475(95$ per year $)$ & $160(32$ per year $)$ \\
\hline
\end{tabular}

Source: corresponding WMEATs, in Millions (Includes Cuba for the Soviet Bloc and Honduras, Guatemala, Nicaragua, and El Salvador for the West) 
Table 20.

Soviet and Economic Aid to Cuba

Years Soviet Union

1970-1974-Middle Détente 240

1975-1979-Late Détente $\quad 1180$

Source: Bach, in Millions-comparable five year time periods

Table 21.

Economic Aid to Nicaragua by Respective Countries/Agencies

Years Soviet Union Mexico Western Europe UN/World

Source: Stokes, in Millions

Table 22.

Soviet and Western Bloc Military Aid to South America

\begin{tabular}{lll}
\hline Years & Soviet Bloc & West \\
\hline 1967-1976-pre/Early & 165 & 2345 \\
1973-1977-Middle Détente & 550 & 2051 \\
1974-1978- Middle Détente II & 605 & 2745 \\
1975-1979-Late Détente & 650 & 2835 \\
\hline
\end{tabular}

Source: corresponding WMEATs, in Millions

Table 23.

Western Military Aid to South America

\begin{tabular}{lcccccc} 
Years & US & France & UK & Germ. & Canada Italy \\
\hline 1967-1976-pre/Early Détente & 917 & 555 & 423 & 270 & 270 & 0 \\
1973-1977-Middle Détente & 586 & 470 & 525 & 325 & 325 & 130 \\
& 610 & 535 & 550 & 400 & 410 & 240 \\
1974-1978- Middle Détente II & & & & & & \\
1975-1979-Late Détente & 660 & 675 & 635 & 440 & 440 & 350 \\
\hline
\end{tabular}

Source: OECD (U.S.), in Millions 
Table 24.

Soviet and Western/Chinese Bloc Military Aid to Afghanistan and Pakistan

\begin{tabular}{lll}
\hline Years & Soviet Bloc & West-China \\
\hline 1974-1978-Middle Détente I & 350 & 755 \\
1975-1979-Late Détente I & 475 & 850 \\
1976-1980-Late Détente II & 460 & 1080 \\
\hline
\end{tabular}

Source: corresponding WMEATs, in Millions-comparable five year time periods (Includes Pakistan and Afghanistan)

Table 25.

Soviet and Western Bloc Military Aid to Buffer Zone

\begin{tabular}{lll}
\hline Years & Soviet Bloc & West \\
\hline 1964-1973-pre Détente & 1810 & 1960 \\
1967-1976-pre/Early Détente & 4180 & 4460 \\
1973-1977- Middle Détente & 4340 & 5900 \\
1974-1978-Late Détente I & 5920 & 8250 \\
1975-1979-Late Détente II & 8020 & 9900
\end{tabular}

Source: corresponding WMEAT, in Millions (Includes Iran, Iraq, Pakistan, India, Nepal, Bangladesh, and Afghanistan)

Table 26.

Soviet and Western Economic Aid to Buffer Zone

\begin{tabular}{lll}
\hline Years & Soviet Bloc & West \\
\hline 1965-1969-Early Détente & 871 & 5463 \\
$1970-1974-$ Middle Détente & 1058 & 2935 \\
$1975-1979-$ Late Détente & 2706 & 3469 \\
\hline
\end{tabular}

Source: OECD (U.S.), Bach (U.S.S.R.), in Millions (Includes Iran, Iraq, Pakistan, India, Nepal, Bangladesh, and Afghanistan). The Soviet Bloc is comprised of the Soviet Union, Czechoslovakia, Poland, and East Germany. The Western Bloc is comprised of the U.S., France, U.K., Germany, Canada, and Italy. 
Table 27.

Soviet and US Economic Aid to Afghanistan and Pakistan

\begin{tabular}{lll}
\hline Years & Soviet Union & US \\
\hline $1972-1980$-Détente & 704 (78 per year) & 2160 (240 per year) \\
1975-1979-Late Détente & $609(122$ per year $)$ & 1530 (306 per year) \\
\hline
\end{tabular}

Source: Bach (U.S.S.R.), OECD, in Millions

Table 28.

Soviet Economic Aid to Afghanistan and Pakistan

\begin{tabular}{|c|c|c|}
\hline Years & Afghanistan & Pakistan \\
\hline 1965-1974-Early Détente & 145 (15 per year) & 56 (6 per year) \\
\hline 1975-1979-Late Détente & 255 (51 per year) & 354 (71 per year) \\
\hline
\end{tabular}

Source: Bach, in Millions

Table 29.

Soviet Military Aid to Eastern Europe

\begin{tabular}{ll} 
Years & Soviet Union \\
\hline 1964-1973-pre-Détente & $4400(440$ per year $)$ \\
1967-1976-pre/Early Détente & $7140(714$ per year $)$ \\
1973-1977- Middle Détente & $7340(1468$ per year $)$ \\
1974-1978-Late Détente I & $7830(1566$ per year $)$ \\
1975-1979-Late Détente II & $7000(1400$ per year $)$ \\
\hline
\end{tabular}

Source: corresponding WMEATs, in Millions

Table 30.

Soviet Subsidies to Eastern Europe

\begin{tabular}{ll} 
Years & \\
\hline $1970-1973$ Early Détente & 2485 per year \\
$1974-1979$ Late Détente & 7283 per year
\end{tabular}

Source: Marrese, in Millions 


\section{REFERENCES}

Bach, Q. (2003). Soviet Aid to the Third World. Book Guild

Bissell, R. (1978) “Testing Détente.” Proceedings of the Academy of Political Science. Vol. 33, pp. 88-98

Central Intelligence Agency. (1986) The Soviet-Cuban Connection.”

Eckstein, S. (1989) “Foreign Aid: Cuban Style.” Multinational Monitor. Volume 10. Retrieved December 2005 from

http://multinationalmonitor.org/hyper/issues/1989/04/eckstein.html

Enkhsaikhan, A. (1999) "Nuclear Weapon Free Status." Paper Presented at the UN Regional Meeting on Security Concepts in the Changing World. Retrieved June 2005 fromhttp://www.un.int/mongolia/Sub_Doc_3/Statement\%20by\%20amb.J.Enkhsaikhan\% 20Nuclear\%20Weapon\%20free\%20status\%20Aug3-5\%201999.htm

Grabendorff, W. (1985). "The U.S. and Western Europe: Competition or Cooperation in Latin America.” International Affairs, pp. 622-641.

Grey, R (1984). "The Soviet Presence in Africa." Journal of Modern African Studies. Volume 22, pp. 511-527

Kahn, O. (1987) “Cuba's Impact in Southern Africa.” Journal of Interamerican Studies and World Affairs Vol. 29, pp 33-54

Laird, R. (1984) "Soviet Arms Trade with the NonCommunist Third World."

Proceedings of the Academy of Political Science. Volume 35, pp. 196-213

Lawson, Colin. (1988) "Soviet Economic Aid to Africa." African Affairs. Volume 87, pp. 501-518

Leogrande, W. (1982) “Cuba Policy Recycled.” Carnegie Endowment for International Peace, pp. 105-119

Nation, C., Kauppi, M. (1994). The Soviet Impact in Africa. Lexington/Heath Press

Marrese, M. (1986) "CMEA: Cumbersome but Effective Political Economy." International Organization. Volume 40, pp. 287-327

Menon, R. (1982) “The Soviet Union, the Arms Trade and the Third World." Soviet Studies. Volume 34, pp. 377-396 
Organization for Economic Co-operation and Development. (1971-present). Stat

Extracts. Retrieved May 26, 2006 from http://stats.oecd.org/WBOS/index.aspx

Prevost, G . (1990) “Cuba and Nicaragua.” Latin American Perspectives. Volume 17, pp.

Radchenko, S. (2003). "The Soviet's Best Friend in Asia." CWIHP Working Paper. No. 42 Retrieved June 2005 from

wilsoncenter.org/index.cfm?topic_id=1409\&...\&group_id=11901

Rupen, R. (1963) “Mongolia in Sino-Soviet Dispute.” The China Quarterly. October, pp. $75-85$

Stokes, D. (2003). “Counterinsurgency, Coups, and Coercion.” ZNet Magazine.

Retreived November 2005 from

http://www.globalpolicy.org/empire/history/2003/0402counterinsurgency.htm

Suchlicki, J. (1987) "Soviet Policy in Latin America." Journal of Interamerican Studies and World Affairs. Vol. 29, page 31.

United State Disarmament Agency (1964-1976). World Military Expenditures and Arms Transfers. pp. 68-71

United State Disarmament Agency (1967-1976). World Military Expenditures and Arms Transfers. pp. 158-160

United State Disarmament Agency (1973-1977). World Military Expenditures and Arms Transfers. pp. 156-158

United State Disarmament Agency (1974-1978). World Military Expenditures and Arms Transfers. pp. 157-161

United State Disarmament Agency (1975-1979). World Military Expenditures and Arms Transfers. pp. 128-131

United State Disarmament Agency (1976-1980). World Military Expenditures and Arms Transfers. pp. 128-131

Weatherbee, D. (1978) "U.S. Policy and the Two Southeast Asias." Asian Survey. Vol. 18, pp. 408-421 
Chapter IV: U.S. Archives and the Soviet Response in the Third World during Détente Introduction

In Chapter Four I examine archival documents from the Carter administration and the respective U.S. agencies during the Carter era (the Africa section includes Ford) to analyze Soviet actions during the Détente time period from the U.S.'s point of view. Documents from U.S. intelligence agencies (such as the CIA, State, Defense, and NSC), along with those of the U.S. executive branch, should provide a wealth of information about how U.S. decision-makers interpreted the balance of power during the late 1970's (some Cuban and Soviet archives are interjected with the U.S. analysis). Thus, I seek to capture the foreign policy view of significant players and policymakers within the U.S. foreign policy apparatus. Did these leaders suggest that Soviet Bloc actions in the late 1970's were aggressive or cautious? If so, why did they believe so?

I separate the archives according to six specific regions that were highlighted in the introductory chapter. These regions include Latin America, Asia, Sub-Saharan Africa, the Middle East/Northern Africa, the Buffer Zone, and Eastern Europe. Approaching the study in this fashion gives me the opportunity to understand where exactly U.S. foreign policymakers believed the Soviets were mounting an aggressive push. Most importantly, do I find U.S. policymakers contending that the Soviets were overturning Western influence in vital areas of the world or just marginal ones?

Chapter four will also examine the U.S.'s interpretation of Soviet actions in the strategic nuclear realm during the late 1970's. As I mentioned in first chapter, some suggests that the strategic nuclear arms race was much more significant to the end of Détente than conflict in the less developed world. Thus, I will evaluate what U.S. 
policymakers believed at the time. In any case, even if the strategic arms race was more important, the analysis of revolutionary conflict in the less developed world and the Soviet role in that conflict was certainly a contributing factor to Détente's collapse.

The synthesis of the regional and archival approaches is designed to test the competing theories of U.S. foreign policy laid out in this dissertation. These theories include realism, structural Marxism, and bureaucratic politics. Should I find significant chasms between different agencies in several regions of the world it would lend significant credibility to the bureaucratic politics approach. Evidence for this would be found in the form of one or several agencies pushing for a cautious approach while one or several competing agencies would push for a more aggressive approach. Should I find little or no significant chasms between different U.S. foreign policy agencies, then that would only strengthen the explanatory potential of either realism (aggressive U.S.S.R.) or structural Marxism (cautious U.S.S.R.).

Of course, suffice it to say that the evidence from the previous chapters did not help push the case of traditional balance of threat realists. I did not find any significant evidence that the balance of power shifted in favor of the Soviet Bloc nor did I discern that the Soviet Bloc's foreign aid contributions were significantly aggressive. Such a finding has given structural Marxism an advantage over balance of threat realism. Thus, chapter four will analyze the view of U.S. decision-makers in order to determine whether this advantage remains consistently accurate. In addition, this chapter gives me the opportunity to introduce bureaucratic politics as I can now analyze whether different intelligence agencies possessed different views of Soviet actions. 
The Bureaucratic Battle between Cyrus Vance and Zbigniew Brzezinski:

\section{Section Introduction}

A good way to begin chapter four is to highlight the foreign policy battles during the final years of Détente between the State Department and the rest of the intelligence community (DIA, NSC, and CIA). The State Department, represented by Cyrus Vance, argued that the Soviet threat was far from imminent. Brzezinski and the rest of the intelligence community, on the other hand, believed the Soviets were placing significant pressure on the balance of power in the less developed world. They argued that the failure of the West to demonstrate strength and resolve towards Soviet interventions in Vietnam, Angola, and elsewhere was leading to increased Soviet adventurism and aggression in many parts of the world that were vital to Western security and economic interests.

\section{Brzezinski and the Hard Line View}

Parsing through key National Intelligence Estimates from November of 1977, I find a significant gulf within the U.S. intelligence community in regard to Soviet capabilities and intentions in the late 1970's. These reports lay out two competing views. The first view, which was supported by Brzezinski and much of the Defense community, the CIA, and NSC, argues that the Soviets were ready to pounce on any sign of Western weakness. The hardliners argued that "in the Soviet view, the correlation of forces has in the 1970's shifted in the U.S.S.R.'s favor and that this trend is likely to continue" ("Soviet Goals and Expectations", p. xii). They also argued that Soviet leaders believed that "the U.S. and its allies had entered upon a new stage of "general crisis of capitalism" that will prove irreversible" ("Soviet Strategic Objectives", p. 15). As a result, the 
hardliners argued that the Soviets were ready to make gains at the expense of the Western alliance in the less developed world.

These views led to aggressive actions on the part of the U.S. As chronicled by Brzezinski (1983) in his memoir, entitled Power and Principle: Memoirs of the National

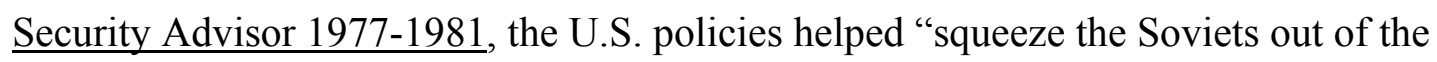
game" in the Middle Eastern talks between the Israelis, Egyptians, and Arabs, pressed "China into anti-Soviet military preparations in the Far East" through the further use of the "China Card", and convinced the "whites that there was a future for them" in South Africa $(113,196,143)$. Diplomacy was simply dismissed by Brzezinski and his hard-line Bloc. Rather than negotiate with the Soviets in the Middle East or the Angolans in Southern Africa, Brzezinski pushed against dialogue and in favor of aggression.

\section{The Doves: Vance and the State Department}

A contrasting view, that of Cyrus Vance and much of the State Department, argued that Soviet leaders were considerably worried about the "U.S.S.R.'s economic and technological weaknesses and its conflict with China" ("Soviet Goals and Expectations in the Global Power Arena", p. 16). Vance and the State Department also argued that the Soviets attributed a great deal of "resilience to the capitalist economies and do not discount the recent turnaround in U.S. defense spending as a short-term phenomenon" ("Soviet Goals and Expectations in the Global Power Arena", p. 16). In short, this view posits the U.S.S.R. in the late 1970's as trying to "keep pace" with the West.

Therefore, former Secretary of State Vance's memoir, entitled Hard Choices (1983), comes out strongly against the asymmetrical realism of Brzezinski. He suggests that many of the problems in the world, especially the less developed world, had nothing 
to do with the Soviet Bloc. Vance argued that one of the major flaws of U.S. policy in the 1960's and 1970's "was that it was too narrowly rooted in the concept of overarching U.S.-Soviet geopolitical struggle” and not enough on the potential for U.S.-Soviet cooperation across a range of issues (p. 27). Such issues included arms limitation talks and trade talks.

Rather than using the aggressive realpolitik tactics of Brzezinski, Vance (1983) and the State Department also argued in favor of human rights. In their view, the promotion of human rights, especially in strategic areas of the less developed world, would help the U.S. pursue its trade interests while also curtailing the potential for the Soviet Bloc to take advantage of future revolutions in those oppressed countries (p. 120). Vance (1983) ultimately argued that he called on the U.S. to reduce U.S. assistance to many U.S.-backed murderous regimes, such as those in El Salvador and Nicaragua (p. 122).

Of course, suggesting that Vance's views permeated the State Department must be further examined in the U.S. archives. Did Vance, and most importantly the State Department, truly believe that the Soviets did not pose a significant threat to the world balance of power? Could it be, as many on the left have suggested, that the State Department preferred to advance U.S. interests through the economic domain? These questions will be answered once I examine the archives below.

\section{The Hawks Win}

The victor in this struggle for bureaucratic influence was none other than Brzezinski and the hawks. Although President Carter seemed to have initially agreed with many of the ideas promoted by Vance, he eventually came to adopt Brzezinski's instead. 
Why did President Carter make this decision? Did he firmly believe that the Soviets had become a far graver threat then he had first perceived?

The answer to this is apparently yes. Carter's Presidential memoirs, entitled Keeping the Faith (1982), suggests that Brzezinski had firmly convinced him that the Soviets were engaged in large scale attempts at destabilizing U.S. and Western areas of interest in much of the less developed world (p. 53). However, it also seems that President Carter was “turned off" by the State Department. Carter writes that the State Department never produced new ideas, churned out public statements that were "always mild and cautious, and rigorously assessed plans to the breaking point” (p. 53). In sum, he argues that Vance "mirrored the character of the organization he led" (p. 53). On the other hand, Carter viewed Brzezinski as a "first rate thinker" who led a strong NSC staff to produce new ideas and "incisive analyses of strategic concepts" (p. 53).

\section{Probing Further into the Archives}

The battles between Vance and Brzezinski (between the State Department and Defense Department during the late 1970's cannot be extrapolated (on their own terms) to suggest a significant chasm between U.S. foreign policies agencies in regard to the Soviet threat in the entire less developed world and the collapse of Détente. While they frame the debate in a constructive manner, especially in regard as to why I need to study the domestic politics approach, I must delve further into these respective foreign policy intelligence agencies (and the Carter Presidency) in order to determine whether these respective viewpoints had become crystallized within each respective agency.

Overall, studying each respective agency further will be vital to the explanatory potential of realism and structural Marxism. The previous chapter already began to give 
structural Marxism an advantage over balance of threat realism as I did not find that the Soviets were allocating foreign aid in a manner that was more aggressive than the West. Chapter four will allow me to test whether structural Marxism, arguing that the Soviets were cautious, holds out against balance of threat of realism and its proposition that the Soviets were aggressive in the less developed world during the final years of Détente. I will also introduce the theory of domestic politics in chapter four. Domestic politics argues that U.S. agencies ultimately battled it for control over the direction of U.S. foreign policy. Now that I am introducing the agency archives, I will begin to test domestic politics.

\section{Regional Analysis}

\section{Section Introduction}

I mentioned in the beginning of this chapter that the regional section will explore the U.S.'s interpretation of the Soviet threat in the less developed world during the final years of Détente. Do I find a singular and dominant U.S. interpretation of the final years of Détente or was there competition between U.S. agencies (and the U.S. Presidency) in regard to differing views on Soviet foreign politics.

Of course, it must be understood that differing agencies will place different types of emphasis on the Soviet threat depending upon their "intellectual mission." For example, the Defense Department is going to emphasize military spending much more than the State Department would. However, there could come a point in which the customary bureaucratic competition for executive attention and federal resources could exceed a significant threshold. 
Bureaucratic conflict would be evident should one agency (or set of agencies) advocate a significantly more aggressive or less aggressive foreign policy than another agency (or agencies). Indeed, should I find a significant split between competing U.S. foreign policy agencies (and President Carter), I will then probe whether this split can be found in all the regions of the world and/or the most vital and strategic areas of the less developed world. If this is the case, bureaucratic politics/domestic politics would have a significant explanatory advantage over realism and structural Marxism.

Once I have finished my regional analysis of the U.S.'s outlook of the Soviet threat in the less developed world, I shall also analyze U.S. archives to determine the effect the race for strategic nuclear arms had on the collapse of Détente. The strategic arms section will help me determine which argument, between strategic arms and Soviet involvement in the Third World, was the most dominant in U.S. foreign policy circles. That is, I seek to catalog the primary and secondary reasons for Détente's collapse.

\section{U.S. Archives and the Balance of Power in Asia}

Consistency between U.S. bureaucratic foreign policy agencies in regards to the balance of power in Asia, during the beginning stages of the Détente time period can be found in several CIA-lead Soviet Estimates. A 1973 CIA report entitled "Soviet Military Policy and Posture and Policies in the Third World", which was backed up the State Department and the NSC, concludes that the "presence of a hostile China has had a dampening effect on Moscow's inclination to encourage the appearance of radical or communist regimes or to welcome regional conflicts as opportunities for the extension of Soviet influence" ("Soviet Military Policy and Posture in the Third World", p. 19). These 
findings support, to a large extent many of my findings from chapter two (historical approach) and three (process-tracing/quantitative).

However, I do find a break between these agencies, represented in my analysis below by the State Department, and the Defense Department. For instance, the State Department strongly argued that the rise of ASEAN helped weaken Soviet power in the region while expanding the possibility for U.S. (and Japanese gains). The State Department really hones in on ASEAN's development and its effect on the balance of power. The Defense Department on the other hand was extremely worried that the naval balance of power was shifting in the Soviet's favor.

\section{State Department's Analysis}

\section{Sino-Split Changes the Overall Balance of Power}

An archival analysis of the State Department's unclassified documents pertaining to Asia seems pretty much in line with my earlier findings in previous chapters. For starters, a 1975 declassified State Department briefing memorandum paints an upbeat picture for U.S. policymakers in Southeast Asia. Arguing that "the structure of the Major Power balance in the Far East appears unchanged in its essentials," the memorandum stresses that the Soviets have "probably lost as much ground (versus China) in Northeast Asia (Korea, Japan) as they have gained in Southeast Asia (Hanoi)" ("U.S. Strategy in Asia”, p. 1).

The memorandum all but dismisses the significant of Vietnam. Stressing that the U.S. must be "realistic in setting goals for our policies in Indochina", the report argues that the U.S. "cannot expect to prevent Hanoi's takeover of South Vietnam or its establishment of hegemony over all of Indochina" ("U.S. Strategy in Asia”, p. 25). U.S. 
policy in the region was advised to focus on "discouraging interference by the Indochina states in the territory or affairs of neighboring governments by helping Thailand and Malaysia protect their borders and strengthening their internal security" ("U.S. Strategy in Asia", p. 15).

US Uses ASEAN to Strengthen its Balance of Power Position

Thus, it should be no surprise that I find State Department declassified reports depicting ASEAN Bloc survival as the most important buffer to maintaining political stability in the region (containing the Soviet Bloc) for the West ("US Strategy in Asia", p. 25). Indeed, "U.S. Strategy in Asia" highlights the fact that the rise of the ASEAN Bloc has curtailed Soviet expansion and brought forth new gains for the U.S. and its Japanese ally. It contends that:

despite our disengagement from Indochina and the decline in our military profile in the area, the trend towards the expansion of our trade (and Japan's) and investment in East Asia and the economic integration (into the U.S.-led world system) of the Pacific Basin will continue (p. 26).

The report also highlights a $30 \%$ increase in trade with the region as well as a $25 \%$ increase in U.S. exports to the region.

Another report, entitled "Southeast Asia", contends that "thanks to frequent and candid exchanges on the situation in Indochina and the ASEAN region, we (the U.S. and Japan) have helped "minimize the Soviet presence" ("Southeast Asia", p. 1). In fact, the U.S. was able to convince Japan that "regional stability (deterring U.S.S.R.) would depend on [securing] the economic and political strength of the ASEAN countries" (“Southeast Asia", p. 3). Strengthening ASEAN is exactly why Japan "greatly stepped up its economic assistance" as well was as "trade and investment to the region" ("Southeast 
Asia”, p. 1). After all, integrating its economy with the ASEAN Bloc was seen as essential for both the economic security of Japan and for the political security of the Western Alliance in the region.

\section{Economic Power Trumps Military Power}

All in all, U.S. strategy in Asia seems to suggest that all was well in Asia for U.S. interests during the middle years of Détente. The U.S.S.R. was contained thanks to the Sino-Soviet split, the U.S.-Japanese alliance, and the rise of ASEAN. Most importantly, however, the State Department report also seems to play down the importance of geostrategic and military competition. It explicitly suggests that neither China nor the U.S.S.R., nor developments in Indochina, would have much influence on the "economic forces at play" ("U.S. Strategy in Asia", p. 9). Therefore, the report seems confident that offering better than usual economic deals would undercut revolutionary insurgency as well as any appeal for any nation to ally with the Soviet Bloc. China, the U.S.S.R., and Vietnam were simply not able to compete with the economic power of Japan and the U.S.

State Department reports do take into consideration Soviet increases in the usage of Vietnamese military bases. "Implications to Japan of Soviet Use of Vietnamese Bases", one of these reports, suggest the Japanese shipping routes were now in greater danger ("Implications to Japan of Soviet Use of Vietnamese Bases", p. 2). However, these reports did not suggest such developments were anywhere as significant as the downturn in Soviet momentum in the region. The State Department understood the Soviets were aggravated in the military domain. For instance, a 1983 report entitled the "Soviet Role in Asia" argues that Moscow was deeply frustrated about its "inability to convert its impressive and growing military presence in Asia and the Pacific and Indian 
Oceans into a coherent role...in which the Soviets could project their political and economic influence" ("The Soviet Role in Asia", p. 1). It argues that Soviet exclusive reliance on military power to push forward its goals ultimately undermined the potential for Soviet influence in the region. The Soviets failed to use economic aid as a weapon for political influence (unlike the U.S./Japan in regards to ASEAN). Less trade with both Japan and China was the ultimate result ("Soviet Role in Asia", p. 1).

$$
\text { Defense Department Analysis }
$$

\section{Section Introduction}

While State Department archives all seem to emphasize U.S. and Japanese gains via ASEAN, the Defense Department's analysis of the region during the latter years of Détente focuses a bit more on the U.S./Japan-U.S.S.R. naval (as well as air) conventional balance of power in Northeast Asia. I find this evidence in three declassified reports; "The U.S./Japan-U.S.S.R. Balance (June 1978)", "The Northeast Asia Balance (1977)", and "Northeast Asia: Summary (October 1978)". Every single one of these reports focuses on upgrading U.S. protection for Japan. They suggest that the regional naval balance of power was tilting and rectifying this "seems critical in pursuing U.S. interests and in re-enforcing allied perceptions of U.S. commitments and capabilities" (“U.S./Japan-USSR Balance”, p. 2). These reports also find the Defense Department pleading for more conventional weapons from Washington.

\section{Japan Becoming Vulnerable}

The aforementioned reports saw Japan as becoming more and more vulnerable against the Soviet Bloc. For instance, "Northeast Asia Balance" argues that Soviet capabilities in regards to air power (modernization of bomber and tactical aircraft) and 
naval power (larger number of submarines with cruise missiles and amphibious ships) had significantly increased during this time period. An additional 28 submarines, 5 missile cruisers, 7 missile destroyers, 14 frigates, and the "deployment of the Backfire Bomber in large numbers" were all cited as significant improvements that would increase the ability of the Soviet fleet to threaten Japan (as well as Korea) ("Northeast Asia Balance", p. 1).

Another example of the Department of Defense's Asian perspective can be found in its defense of the 1977 Japanese Defense White Paper. "Your Meeting with Ganri Yamashita", which describes a meeting with the U.S. and Japanese secretaries of defense, finds U.S. Secretary of Defense Harold Brown telling his Japanese counterpart that he did see the Western-Soviet strategic balance of power moving dangerously in favor of the Soviet Bloc ("Your Meeting with Ganri Yamashita", p. 5). He tells the Japanese Secretary of Defense that his department was working diligently to help procure military resources for U.S. upgrades ("Your Meeting with Ganri Yamashita", p. 6). Nonetheless, Secretary Brown also told his Japanese counterpart that Japan must modernize its air defenses, taking more responsibility over its defenses, in order to counter the Soviet threat.

Ultimately, U.S. Secretary of Defense Harold Brown sought to soothe Japanese fears in 1979. The Japanese were concerned about a Defense Department staff study entitled the "Swing Strategy". This leaked study called for the U.S. to "swing" the Pacific fleet over to Europe should the U.S.S.R. mount an attack against Western Europe. 


\section{Defense Department in the Minority and Overall Soviet Caution}

It seems obvious that the State Department and the Defense Department had different perspectives about the most important aspects of U.S. policy in this region and about the balance of power. The Defense Department was ultimately in the minority. President Carter's NSA Advisor at the time, Zbigniew Brzezinski, finds (as compared with the early part of the 1970's) that "U.S. relations in Asia were [more] favorable [now]" thanks to stronger relationships with Japan, China, Indonesia, and India ("U.S. National Strategy", p. 2). In the end, for Brzezinski (and his NSC) to weigh in on the side of the State Department is extremely revealing. As you will see in the rest of this dissertation, Brzezinski and his NSC often proved to be an intransigent roadblock for the State Department's efforts in other regions (such as Afghanistan and Angola).

Regardless, the important thing is that most U.S. agencies argued that the ability of the Soviets to improve their balance of power standing had been considerably reduced by the final years of Détente. The main reason for this was the Sino-Soviet split. Indeed, even after the Vietnamese invasion of Cambodia in late 1978, I still find State, Defense, NSC, CIA, and President Carter concluding in June of 1980 that the Soviets were concerned about the increasingly negative effects of Sino-U.S. normalization and the new military alliance between China, Japan, and NATO ("U.S.-Soviet Relations and SALT", p. 5). At the end of the day, it was apparent to U.S. officials, such as U.S. Ambassador to Japan Sherman William, that the "Sino-Soviet confrontation has created a favorable situation for the free world (since 1969). The PRC [China] serves a useful function in countering Soviet military strength" ("Security Issues at the Meeting between Prime Minister Fukuda and President Carter”, p. 2). 
Overall, the archival data serves to further weaken balance of threat realism. Soviet caution goes against the theoretical canons of balance of threat realism. Of course, I must wait for further evidence to dismiss this thesis.

Nonetheless, if the Soviets were not aggressive, why did the State Department place a significant amount of emphasis on ASEAN while the Defense Department did not furnish ASEAN this central attention? The theories of bureaucratic politics and structural Marxists can offer some suggestions. Bureaucratic politics would argue that the Defense Department had different interests than the State Department. Structural Marxists would contend that the State Department encompasses the "economic imperialist" wing of the U.S. while the other agencies encompass the military imperialist wing. Structural Marxists believe these different wings are created to reinforce each other.

U.S. Archives and the Balance of Power in the Middle East

\section{Section Introduction}

The archival record is extremely clear in regard to the Middle East. The Soviets did not make gains in this vital region of the world. All significant national security intelligence agencies agree to this. I do not find any dissenting views in this regard. These findings nicely confirm my findings from chapter two (historical approach) and three (process-tracing/quantitative).

\section{U.S. Agencies and the Balance of Power in the Middle East}

Foreign policy unity, among major U.S. agencies, can be found in "Soviet Goals and Expectations in the Global Power Arena." This major CIA-led U.S. intelligence report (also supported by State, NSC, and the Defense Department) argues that the Soviets did not make balance of power gains in the Middle East. In fact, the part of the 
less developed "considered of greatest concern to the Soviet Union" is where the Soviets “since the early 1970's endured a succession of severe setbacks, most notably their humiliating expulsion from Egypt (which occurred in the mid 70's)" ("Soviet Goals and Expectations in the Global Power Arena", p. 52). In addition, in regard to Soviet gains in Libya and Yemen, the May 1978 U.S. intelligence report suggests that such gains were "poor compensation for their losses" ("Soviet Goals and Expectations in the Global Power Arena", p. 52).

The loss of Soviet influence does not end there. The report further cites several "converging" developments to show that "Soviet freedom of action has been constricted" ("Soviet Goals and Expectations in the Global Power Arena", p. 52). These developments included the rise of the oil-producing states (Saudi Arabia and Iran), Soviet failings to counter Israeli influence through the Palestinian Liberation Organization, and the increasing tilt of the radical Arab nations towards the industrial West. Thus, the U.S. archives show that the Soviet Bloc was losing ground in the region while the U.S. and its allies were increasing their gains. Even Japan (according to the NSC) was helping to enhance the Western Alliance in the region with its "generous" economic aid packages towards Egypt and Turkey in 1979 (“Japan and the Middle East”, p. 1).

Additional support for this thesis can be found in another report from the CIA. "Changes in the Middle East: Moscow's Perceptions and Options", a CIA report from 1979, underscores the Soviet Bloc's "marginal" ability to injure U.S. interests in this region of the world. Framing the discussion around the theoretical possibility that the Egyptian-Israeli peace treaty could push some Arabs nations to move closer to the Soviet Bloc, the report cites a list of political (U.S.S.R. does not hold the key in the Arab-Israeli 
conflict), military (U.S.S.R. does not want to fight the U.S.), and economic (Arab nations desired Western currency and technology) impediments to such a prospect ("Changes in the Middle East”, p. iii). Thus, the Egyptian-Israeli peace treaty was to the benefit of the U.S. The treaty was helping to drain the swamp of Soviet opportunities.

The Soviets in the Horn of Africa

Did the Soviets make up this ground in the Middle East by turning up the heat in the Horn of Africa? "Soviet Goals and Expectations in the Global Power Arena" does not believe so. Rather than follow the rhetoric espoused by some hawks (Brzezinski's public comments come to mind) that the Soviet Bloc was striving to gain complete control of the Horn, the report accurately describes the limitations of Soviet intervention in the region. For instance, the report points out that "having been ousted from Somalia and the Berbera base because of their support for Ethiopia in the Ogaden conflict", the U.S.S.R. helped the Ethiopians win the conflict ("Soviet Goals and Expectations in the Global Power Arena”, p. 52). I articulated this during my process-tracing approach in the Middle East section of chapter two. Soviet actions were not aggressive, but can instead be described as an attempt to hemorrhage "an increasing threat to the credibility of their pretensions to status as a great world power" ("Soviet Goals and Expectations in the Global Power Arena”, p. 53). Since the Soviets were less optimistic now about making gains in the Middle East, the report describes the Soviet actions in the Horn as an attempt to "advertise Soviet-Cuban capabilities nationalist movements" in Sub-Saharan Africa (as the Horn served as a bridge to the rest of Africa) ("Soviet Goals and Expectations in the Global Power Arena”, p. 53). 


\section{Section Conclusion}

By and large, my analysis of the U.S. agencies shows that the Soviet Bloc was extremely cautious in this area of the world (which was also found in the historical and foreign aid quantitative evidence from the previous chapters). The fact that the CIA, NSC, and Defense (all usually considered more hawkish than State) perceived the Soviet threat in the Middle East during the late 1970's to be cautious speaks volumes about the U.S.S.R.'s weaknesses in the region. Indeed, the aforementioned reports argued the political and economic landscape of the Middle East favored the U.S. and its surrogates in the region. Once Egypt turned against the Soviet Bloc, the cards were simply stacked against the Soviets.

The archival evidence in this chapter, coupled with the evidence in the previous chapter showing the Soviet Bloc was cautious, diminishes balance of threat realism in favor of structural Marxism. Structural Marxists can clearly argue that the U.S. was determined to defend the area of the world that was most strategic to the interests of U.S. and Western capital and thus took aggressive action to secure this area. Domestic politics seems rather weak in this region. I do not find any chasms between any U.S. intelligence agencies.

\section{U.S. Archives and the Balance of Power in Sub-Saharan Africa}

\section{Section Introduction}

My archival examination of Sub-Saharan Africa focuses on Angola as it was the single most strategic country that was in dispute in this region. My analysis will focus of the initial outbreak of violence during the middle part of the 1970's. Overall, I will seek to determine which superpower, if any, was primarily responsible for the Soviet gain of 
Angola. Did the Soviets pluck this strategic country away from the West or did the U.S./West perhaps push Angola towards the hands of the Soviet Bloc (notwithstanding the long-standing Portuguese exploitation of Angola). I will also study the role of Cuba during and throughout the initial Angola civil war. Was Cuba selected and pushed as a Soviet-driven proxy to fight for Soviet interests in the less developed world?

On the whole, my analysis yields interesting results. I initially find the NSC and the State Department to be on the same page. The initial documents from the NSC suggest that the Soviets were cautious in early 1975 (backing up the historical and foreign aid quantitative findings from the previous chapters). The initial archives (June of 1975) from the State Department also described Soviet actions in Angola as "modest." After all, State Department documents argued that Soviet aid was only helping the MPLA level the playing field with its competitors. The National Union for the Total Independence of Angola (UNITA) and the National Liberation Front of Angola (FNLA) had already received several months of assistance from China and the U.S. However, the NSC's and the State Department's analysis of Soviet actions in Angola during mid-1970's (once MPLA achieves victory) eventually gives way to a more aggressive one. Subsequent documents from the latter part of 1975 argued that the Soviets had been determined to reverse the balance of power in the Sub-Saharan Africa region.

I also examine whether or not Cuba was truly a Soviet proxy during the initial launch of the conflict. Considering much of the initial support to the MPLA came from Cuba, examining the ties between Cuba and the U.S.S.R. is very significant. Were the Soviets truly pushing the Cubans to fight in Angola? My research suggests this was not the case. The Cubans wished to fight in Angola, they pushed the Soviets into Angola, and 
they were even willing to help in Angola when the potential for Soviet assistance to dry up was a possibility. In addition, NSC and State Department archives do acknowledge that Cuba was not just another Soviet proxy. These agencies admit that Cuba's actions in Sub-Saharan actions did take into consideration Cuba's political and strategic interests. The NSC's Analysis of Angola before and after MPLA Claims Victory

Declassified reports from the NSC, such as "United States Policy toward Angola" and its second version also entitled "NSSM-224 United States Policy towards Angola", which were all written before the MPLA achieved victory, put forward the view that placating local regional allies explains Soviet assistance towards the MPLA. They contend Soviets did not seek to alter the balance of power in Angola at the time. Quite the contrary, both reports argue that "the Soviets would appear to have few, if any, important economic or strategic interests in Angola and their support for the MPLA appears to be dictated by their desire to maintain credibility and influence with their various clients-the MPLA, Congo, Algeria, and the communists in Portugal" ("NSSM-224 United States Policy toward Angola", p. 56).

On the other hand, the same report still argues that communist assistance was of "major significance" to the MPLA in early 1975. Were it not for Soviet Bloc military assistance, MPLA aggression in Southern Angola would not have been possible. Moreover, the battles instigated "by the MPLA (in early 1975), resulted in a significant improvement of the MPLA's military fortunes at the FNLA's expense and made it increasingly difficult for UNITA to maintain its preferred role as natural mediator above the fray" ("NSSM-224 United States Policy toward Angola", p. 56). As such, the NSC 
summarized that Soviet/MPLA actions were slightly aggressive. Soviet/MLA actions ultimately created the conditions for a possible civil war.

Once the MPLA declares total victory, I do find the NSC arguing that the Soviets were determined (from the get-go) to seriously alter the balance of power. "Approaches to Dealing with the Soviet Union" and "The Soviet Union; Europe; The Middle East; South Asia; Angola" are two December 1975 reports published with the assistance of the NSC. Highlighting important conversations between President Ford, Secretary of State Kissinger, and Chinese Premier Mao Zedong, the reports suggest the Soviet actions in Angola were nothing short of expansionist ("Approaches to Dealing with the Soviet Union”, p. 4).

State Department Analysis of Angola before and after MPLA Claims Victory

The initial reports from the State Department back up the initial ones from the NSC. In fact, the State Department responded to the NSC's "United States Policy Towards Angola" with a special memorandum on June 25, 1975 and concurred with the initial NSC report. It argues that "up until now their [Soviet] interests appeared modest" ("Special Sensitive memorandum Regarding the Response to NSSM-24", p. 5). Other documents from the State Department also contend that Soviet assistance towards the MPLA in March of 1975 was allocated in a manner as to bring the MPLA up to par with the FNLA (Bender, 1978, para. 8). Soviet aid towards the MPLA was only making up for all of the months of assistance that the FNLA had received from China (primarily) and the U.S.

Subsequent reports from the State Department suggest the Soviet Bloc was an aggressive actor in Southern Africa in early 1975. "A Brief Chronicle of Events in 
Angola", a secret State Department report from that year, argues that "a substantial increase in Soviet military assistance (to the MPLA) took place in March of 1975, when both air and sea deliveries were noted" ("A Brief Chronicle of Events in Angola", p. 2). Such massive Soviet assistance to the MPLA, during the time in which the Alvor Agreement (a peace treaty among the MPLA, FNLA, and UNITA) was signed meant the Soviets (or the MPLA) did not take the agreement very seriously. "A Brief Chronicle of Events in Angola", as well as another State Department report from late 1975 entitled "Discussion of U.S. Policy and Soviet Involvement in Angola", contended that instead of promoting peace in the region, Soviet military assistance in early 1975 served to turn the MPLA into an "intransigent" and aggressive force in the region ("Discussion of U.S. policy and Soviet Involvement in Angola", p. 2). In fact, Soviet arms "changed the balance of power and ruined any hopes for a compromise" ("Discussion of U.S. policy and Soviet Involvement in Angola", p. 3). Soviet aid beefed up the MPLA to the point where it believed it could run roughshod over the FNLA and UNITA despite the fact that these two groups together comprised a majority of the citizens of Angola.

The latter views of the State Department seem quite hypocritical however. A State Department report in June, one month before the MPLA achieved total victory, actually admits that a Soviet-backed MPLA victory would probably occur anyway ("Special Sensitive Memorandum Regarding the Response to NSSM-24”, p. 2). Why the sudden reversal?

\section{Cuba's Role in Sub-Saharan Africa (Cuban and Soviet Archives)}

To better understand what was occurring in this region it would be wise to study Cuba's role in the Angolan conflict. There is evidence that Cuba actually pushed the 
Soviets. Newly released documents from the Soviet Bloc, as well as Cuba, assert that Cuba was very much an independent instigator in the Angolan civil war.

For instance, Soviet archives argue that the initial deployment of Cuban troops in early 1975, in order to help the MPLA declare itself the leaders of the national government in Angola, came completely without the consent of Soviet leaders (Une Odyssee Africaine). N. Broutens, a member of the Soviet Politbüro, claims that the Soviets were enraged by these Cuban actions. The Soviet Bloc was striving for caution in this region and their most immediate pressing issue at the time was only to "prevent apartheid from making itself comfortable in Angola" (Une Odyssee Africaine). Pushed in by the Cubans, the Soviets had no choice but to defend their allies and their credibility.

Cuban documents from 1975, recently retrieved by Peter Gleijeses (2003), in Conflicting Missions: Havana, Washington, and Africa, 1959-1976, also contends that Cuba initially intervened in Angola without the consent of the Soviet Bloc (p. 4). They firmly capture why Cuban leaders were determined to get involved in Angola in the first place. The Castro regime ultimately believed, as some U.S. documents suggest down below, that supporting left-wing revolutions in the less developed world would hurt the economic and political interests of the U.S. (Gleijeses, p. 6). They truly hoped that by embroiling the U.S. in costly and distant conflicts they would invariably be defending their own revolution at home. The weaker the U.S. was and the more pre-occupied it was in the less developed world, then the less likely it was that the U.S. would seek to engage in counter-revolutionary activity in Cuba.

Gleijeses (2003) also retrieved documents from 1975 that show how Cuba was more than willing to aid the Angolans in their fight against the U.S. "imperialists" even 
without significant support from the U.S.S.R. His archival research also shows Cuban leaders (such as Raul Castro and Raul Diaz Arguellas) and Angolan President Agostino Neto agreeing that Soviet assistance towards Angola was not enough (p. 134). Neto goes on to blast the Soviets for not stepping up in the fight between socialism and the forces of imperialism. However, the Cubans would simply not be deterred in aiding the Angolans. The Cubans responded to Neto's Soviet complaints by stating that they would continue to help the Angolans "indirectly or directly" in this cause.

\section{U.S. Archives on Cuban Independence}

Though U.S. archives do not specifically suggest Cuba was the primary instigator of the conflict in Angola, they do leave the possibility open. They do contend that Cuba did act in a quasi-independent manner as it pursued its political and strategic interests. For instance, NSC documents admit that Cuba was neither a "slave (to the Soviet Bloc) nor an autonomous international actor" during the late 1970's in Angola ("The CubanSoviet Relationship", p. 1).

In fact, archives from the NSC paint a much more complex view of Cuba's motivations for the war in Angola and throughout the less developed world. The NSC's "Cuban Intervention in the Third World" posits that "Cuba's aggressive posture in the international arena (Angola specifically) evolved directly from Fidel Castro's belief in his historical role as a revolutionary leader of the Third World and from his hostility to the U.S." ("Cuban Intervention in the Third World", p. 1). The Cuban leader was simply determined to lead the "struggle against Western exploitation" ("Cuban Intervention in the Third World", p. 1). After all, the Castro brothers truly believed that Cuba's sovereignty (or perhaps their control of Cuba) was continuously threatened by the U.S. 
Thus, they believed that the best way to defend Cuba was to help unleash continuous "Vietnams" for the U.S. to deal with. Of course, it is understood that Cuba was financially limited in its abilities to project force "without Soviet cooperation and support" "Cuban Intervention in the Third World", p. 3). However, despite this important limitation, the NSC documents suggest that Cuba was not involved in Africa solely or even primarily at the Soviet's behest" (Cuban Intervention in the Third World, p. 3).

Comments from Kissinger, the Secretary of State at the time, also suggest that Cuba had its own political and strategic interests that were independent from those of the U.S.S.R. Speaking with Vice President Spiro Agnew, Kissinger states that:

If Cuba is free to act as a revolutionary surrogate wherever it wants, its prestige in Latin America is bound to rise. If we tolerate Cuban adventures in Africa, it scares the hell out of the Latin American Presidents I talked to on my trip. In Colombia and Venezuela, they were afraid that the Cubans may at some point get all the black Caribbean countries together and make a race war against the Latin American countries which pretend to have integrated societies but really don't. (“SALT, Soviet-U.S. Relations, Angola, Cuba, Africa, PRC, TTBT/PNE", p. 9)

Kissinger's analysis of Cuba's role in Angola firmly demonstrates that Castro's involvement in Angola significantly improved Cuba's ability to pursue its political and strategic interests in Latin America. There was simply more to Cuba's action that pursuing the strategic interests of the U.S.S.R. Kissinger's subsequent comments also leads me to question whether the U.S. was more worried about Cuba's involvement or the Soviet's involvement. He explains to Spiro Agnew that, "I'm going to go to Africa soon and propose a solution for their problems in South Africa. But I can't look as if fear of 
Cuba is driving our position" ("SALT, Soviet-U.S. Relations, Angola, Cuba, Africa, PRC, TTBT/PNE”, p. 9).

\section{Section Conclusion}

Fashioning a conclusion for this section is rather difficult. The initial U.S. documents from the State Department and the NSC argue that the Soviets did not seek to alter the balance of power and that their primary motivation was to mollify its local allies in the region (as the previous chapters showed). Once the MPLA achieved victory however, State Department and NSC archives start to interpret the U.S.S.R.'s assistance towards the MPLA (pre-MPLA victory) in a much different manner. They begin to contend that the Soviet Union was initially determined to reverse the balance of power in the Sub-Saharan Africa.

Ultimately, to better understand what was occurring in Angola during the middle part of the 1970's, the next chapter will turn to analyzing U.S. actions in Sub-Saharan Africa during this time period. Analyzing U.S. actions would certainly help give insights as to how U.S. policymakers were interpreting the balance of power in this region After all, there is some evidence that the U.S. engaged in covert actions during the middle part of 1975. Perhaps this is why the U.S. altered its interpretation of the initial Soviet assistance. Could it be that U.S. agencies were upset that the U.S.'s aggressive actions did not go according to plan?

In regard to the actions of Cuba during the early part of 1975, Soviet and Cuban archives do suggest that Cuba was the more of an instigator in this conflict than the U.S.S.R. U.S. archives also acknowledge that Cuba had a much larger independent role than that which was commonly portrayed in the news media. The NSC and State 
Department archives show that the Cubans had a larger mission in Africa than just pushing ahead Soviet strategic interests.

Overall, the findings in this chapter are mixed. For the first time, there is archival evidence that supports balance of threat realists. The archival research from the CIA/NSC demonstrated this. However, there is also evidence that favors structural Marxism. For those who adhere to bureaucratic politics they would dismiss these two previous theories. They would argue that bureaucratic competition explains U.S. action. As the next chapter will show, the aggressive CIA and the NSC overtook the State Department in the desired U.S. foreign policy approach. They would point to covert actions on the part of the CIA/NSC.

\section{U.S. Archives and the Balance of Power in Latin America}

\section{Section Introduction}

My findings from the U.S. archives show a rather cohesive foreign policy outlook from all agencies towards the balance of power in Latin America. Documents from U.S. agencies prove that Soviet involvement in the region, although increasing, did not make substantial gains in Latin America during the 1970's. Soviet involvement, according to U.S. sources, was minimal. The archives show that the Sandinistas took power in 1979 without much Soviet or Cuban military/economic aid. U.S. archives actually show that the Sandinistas received the bulk of their economic aid from non-communist countries. Finally, the archives also show that Cuban military aid (according to U.S. sources) towards Salvador and Guatemala began in the early 1980's.

Therefore, U.S. archives (CIA, State, and DIA) blame revolutionary turmoil on the economic and repressive policies historically pursued by the U.S. and its clients in the 
region. This is especially the case with Central America. The agency archives also suggest that the rise of the middle/professional classes of the region, such as in El Salvador and Nicaragua, was a significant factor in the growth of nationalism in the region. Overall, economic and political repression in the less developed world, not Soviet aggression, explains the growth of revolutionary zeal in the much of Latin America.

\section{U.S. Agencies Agree that the U.S. is to Blame}

A preponderance of U.S. agencies and archives suggest that Soviet involvement in Latin America was the U.S.'s own fault. Such was the conclusion of an April 1977 CIA-led report (including State and Defense Department participation) entitled "Soviet Interest in Latin America." The final page of the report states that, "in the final analysis, the key factor governing the extent of the Soviet-American relationship is the U.S. The Soviet Union still cannot influence Latin American affairs as much as it can exploit economic and political conditions and U.S. policies" ("Soviet Interest in Latin America", p. 10). As such, as long as the U.S. " fails to develop a consistent and acceptable policy for the region (moving away from exploitation and repression), political opportunism and tactical flexibility will work to Moscow's advantage and further erode U.S. influence" ("Soviet Interest in Latin America", p. 10).

Soviet caution in Latin America is the primary subject of a State Department report (from January of 1980) entitled "The Soviets in Latin America: Trends and Prospects." Indeed, the report stresses that "despite or because of a generally nonprovocative approach, the decade of the 1970's was a mixed record of gains and losses for the U.S.S.R" (“The Soviets in Latin America", p. 3). The failure of the Chilean Marxists to consolidate their power is characterized in the report as a "severe blow to 
Soviet expectations" ("The Soviets in Latin America", p. 4). Although building some new trading relationships in South America and establishing military weapons sales to Peru, the only gain for the Soviets in the region came with the victory of the Sandinistas in Nicaragua.

Rather than provoke the ire of the U.S., the State Department report argues that the Soviet Union's strategy in Latin America was to bide their time "in the Western Hemisphere in the expectation that Latin American disenchantment with the U.S. will rebound to their benefit" ("The Soviets in Latin America", p. 3). The Soviets simply concentrated on improving cultural ties, trading relationships, and building state-to-state relations. Why such a cautionary approach? Besides the obvious fact that direct Soviet intervention would bring the wrath of the U.S. military, the report argues that the Soviets preferred the gradualist approach as they had learned that "anti-U.S. feelings did not automatically translate into pro-Soviet sentiment" ("The Soviets in Latin America”, p. 3). Thus, the Soviets did not believe that a U.S. loss would automatically turn into a Soviet gain. The U.S.S.R. also did not want "the burden of another Cuba in Latin America...The lesson it deduced from Chile was that Marxist revolutions must not only achieve power but must be able to protect themselves once they are in power" "“The Soviets in Latin America", p. 15).

The rest of the foreign policy intelligence community agreed that Soviet policy in Latin America during the late 1970's was cautious. "Soviet Goals and Expectations in the Global Power Arena", a 1978 Soviet Secret Estimate produced by the CIA, Defense, NSC, and the State Department, stated that Latin America received a much "lower Soviet priority" than Africa or Asia (Soviet Goals and Expectations in the Global Power Arena, 
p. 4). U.S. agencies argued that "Moscow's diplomatic posture since the fall of the Chilean President Allende is fundamentally one of watching and waiting” ("Soviet Goals and Expectations in the Global Power Arena”, p. 4).

\section{The Soviets and Nicaragua}

Most significantly, the archives also show that the Soviet Union and Cuba did not materially aid the Sandinistas in the late 1970's. According to the CIA, "the Cubans were cautious in their dealings with the FSLN (in 1978 and early 1979) because they had been skeptical about the group's capabilities and sensitive to international opinion" ("The Situation in Nicaragua", p. 6). The report argues that Cuba "declined repeated Sandinista appeals for money, arms, and increased training outside of Cuba." Cuba's initial support for Nicaraguan revolutionaries in late 1979 consisted of organizational training "to help iron out their factional differences" ("The Situation in Nicaragua", p. 6). It is only several months after the Nicaraguan Revolution that the Cubans substantially aided the Sandinistas.

However, Cuba did provide more than just organizational report to the rest of Central America during the early part of the 1980's. The CIA, in such documents as "Cuba-Nicaragua: Support for Central American Revolutionaries: The First Six Months", "Threat of a Leftist Extreme Makeover in El Salvador", and "Cuba-Nicaragua: Support for Central American Insurgencies", all suggest that Cuba provided a significant amount of military support to revolutionary groups in Central America. Such Cuban actions, however, occurred after the collapse of Détente.

The U.S. archives also show that the Soviet Union did not substantially equip Cuba for any direct type or large-scale involvement in Latin America during the Détente 
time period. The CIA's "Soviet Military Deliveries to Cuba in 1979 and Trends in 1980" shows that the bulk of Soviet military aid during the late 1970's was not geared toward disrupting the political dynamics of Latin America. Soviet military assistance to Cuba during the 1970 's, as argued in the previous chapter, actually aimed at funding Cuba's military operations in Angola. The majority of the Soviet military aid increases (about 7000 tons) from 12,000 tons a year during the $1970-1975$ time periods to 21,000 tons a year between 1976 and 1978 reflected "the replacement of equipment sent by Cuba to Third World countries, particularly Angola" ("Soviet Military Deliveries to Cuba in 1979 and Trends in 1980"). So connected were Soviets' military shipments to Cuba and the war in Angola that it was precisely the waning war in Angola that lead to a significant reduction (about 5000 tons less in 1979 from 1978) in Soviet military aid towards Cuba (Soviet Military Deliveries to Cuba in 1979 and Trends in 1980).

The Sandinistas also did not illicit substantial economic support from other Soviet Bloc nations, such as the Eastern Bloc. Indeed, U.S. archives corroborate my findings from earlier chapters in regard to how the bulk of Nicaraguan assistance came from nonSoviet sources. According to the U.S. Treasury Department, the Soviet Bloc provided only $\$ 102$ million in loans between July 19, 1979 and February 28, 1982 out of a total worldwide pledge of $\$ 1.2$ billion to Nicaragua. Western Europe, with $\$ 129$ million, and Latin America, with $\$ 230$ million, provided substantially more loan support (“Aid to Nicaragua Since the Revolution”, p. 1). Most importantly, loan aid from international institutions (such as the International Development Bank) totaled \$486 million (“Aid to Nicaragua Since the Revolution", p. 1). The Soviet Bloc was also trumped in the 
economic grants category by Western Europe, which was its sole competitor in this category, $\$ 129$ to $\$ 71$ million (Aid to Nicaragua Since the Revolution, p. 1).

\section{The U.S. and Central America}

Thus, U.S intelligence agency archives confirm that U.S. policy was to blame for revolutionary turmoil. In stark contrast to much of the political rhetoric at the time, U.S. archives suggest that the growth of the revolutionary left in Central America in the 1970's, the area of Latin America of most strategic concern to the U.S. was the result of the poverty and political repression that U.S. policy had helped initiate.

"Country Analysis and Strategy Paper: Guatemala", an NSC report, confirms that years of U.S support for politically and economically repressive policies in the region were contributing to revolution in Guatemala. As a result, "Country Analysis and Strategy Paper: Guatemala" argues that "only by providing the people with an everincreasing measure of participation in the political process and in the economic wealth of the country will Guatemala remove the underlying causes of instability" ("Country Analysis and Strategy Paper: Guatemala", p. 1). Thus, the U.S. government, with the backing of the conservative government in power at the time, agreed that best manner in which to preserve the best interests of each respective nation would be through the "the progressive strengthening of democratic institutions and practices; and the implementation of basic economic and social reforms" ("Country Analysis and Strategy Paper: Guatemala”, p. 1).

CIA reports also agree that politically and economically repressive policies in the region were contributing to revolution in Central America. A February 1980 CIA report on El Salvador points out that the "brutal and repressive measures against the poor of the 
population" during the 1950 's and 1960 's by the monopolistic military and the laissezfaire economic policies of the traditional economic elites (pushed by the U.S.) were important reasons for the rise of the communists in El Salvador ("El Salvador: The Potential for Violent Revolution", p. iii).

Robert Pastor (1992), U.S. national security advisor for Latin America under President Carter, argued that the rise of the middle classes in Nicaragua was directly responsible for the increased pressure on the oligarchic regime (p. 25). This is corroborated by U.S. agency reports. These reports argued that the system was stable (kept in check in a brutal fashion) until the emergence of certain sectors of the middle class which "launched new political and interest groups" in the 1960's and 1970's in an attempt to gain a larger share of political and economic power ("El Salvador: The Potential for Violent Revolution", p. 1). Their efforts, the efforts of professionals, teachers, skilled workers as well as the labors of the Catholic Church to end political and economic repression ultimately "swelled the ranks of the Christian Democratic Party" (“El Salvador: The Potential for Violent Revolution”, p. 1).

Overall, U.S. agencies admit that this region had made the "grudging appraisal that they had been overly dependent on the U.S. for political, economic, and military assistance" ("Soviet Interest in Latin America", p. ii) Blaming the U.S. for their economic problems and balance of payments difficulties, the underdeveloped agrarian societies of Latin America became "more receptive to Soviet aid offers" (Soviet Interest in Latin America, p. 8). They also sought to use their "raw materials as an economic lever against the U.S." ("Soviet Interest in Latin America”, p. ii). 


\section{Carter's Perspective}

The belief that poverty and repression in Central America contributed to revolutionary turmoil, can also be found in the archives of President Carter. Following the Sandinista Revolution of 1979, President Carter outlines a memo arguing that the U.S. must push all Central American nations to make "the kinds of reforms necessary to deal with the inequities and inadequacies of the socio-economic and political structures. The alternative is revolution as occurred in Nicaragua" ("SCC Meeting on Central America”, p. 3). President Carter also pushed for humanitarian assistance for Nicaragua in an attempt to befriend the Sandinistas.

\section{Section Conclusion}

These findings demonstrate a rather cohesive foreign policy outlook from all agencies towards the balance of power in Latin America. U.S. archives assert that Soviet involvement in the region, while increasing, did not make substantial gains in Latin America during the 1970's (as chapter two showed). The Soviets feared angering the U.S. and they did not engage in covert actions in the region. Moreover, U.S. agencies (CIA, State, and the DIA) argued that political repression and economic problems significantly contributed to revolutionary turmoil in Latin America. Agency archives also suggested that the rise of the middle class in the region, such as in El Salvador and Nicaragua, was a significant factor in the growth of nationalism in the region. Indeed, the failure of the U.S. to deal with increasing nationalism in the less developed world, and not Soviet aggression, explains the development of revolutionary growth in much of Latin America.

These findings fall right in line with those of structural Marxists. U.S. excesses were responsible for revolutionary turmoil. Balance of threat realists continue to have 
their work cut out for them. Their argument that the Soviets were aggressive in this region during the 1970's does not hold.

\section{U.S. Archives and the Balance of Power in Afghanistan}

\section{Section Introduction}

To understand the U.S. analysis of the balance of power in Afghanistan I shall began by taking a hard look at documents from the State Department and its corresponding embassy in Kabul. These documents suggest that the Soviets were very cautious in light of the revolutionary turmoil that was occurring within its sphere of influence (as the previous historical and quantitative chapters showed). They also match up nicely with recently released Soviet documents that show Soviet leaders putting their utmost effort in trying to prevent having to send troops into Afghanistan. The CIA and NSC, largely silent during in U.S. archival analysis about events in Afghanistan, also seemed to have agreed with many of the assertions made by the State Department. Overall, interagency memorandums suggest the Soviets were going to painstaking means in order to not engage in a military invasion of Afghanistan.

\section{State Department View}

Recently declassified State Department memorandums make the case that the Soviet Union was extremely cautious in Afghanistan during the latter part of the 1970's. "The Afghan Coup", a secret memorandum delivered to Secretary of State Vance describing the 1978 leftist coup (which brought a Marxist regime into power), helps set the stage. "The Afghan Coup" argues that the "Soviets in the past years have acted with restraint toward Afghanistan and it would not seem to be to their advantage to assert control of this important non-aligned country" ("The Afghan Coup," p. 1) It suggests that 
while the Soviets may have tacitly approved of the coup, it was the internal domestic dynamics within Afghanistan that led to the coup in the first place.

Additional archives from the State Department, such as "Soviet-Afghan Relation: Is Moscow's Patience Wearing Thin”, a May 1979 secret State Department briefing memorandum, further chronicle the cautious behavior of the U.S.S.R. This State Department report also suggests the Soviets were concerned about how the internal politics of Afghanistan were causing significant problems for the Soviets. It argues that "the Soviets may be annoyed at the haphazard and precipitous manner in which the Marxist DRA has plunged ahead with its reform programs without building the necessary public support...and [as a result] are facing a drastic rise in hostility among the traditionally xenophobic Afghan people" (“Soviet-Afghan Relations”, p. 2).

The Soviets were also concerned about how their actions in Afghanistan would be viewed by the outside world. Rather than planning out any future invasion, the report mentioned above argues that "the Soviets are concerned by the effect their involvement in Afghanistan is having in the Moslem and Third Worlds (Cuba protesting). We doubt that the Soviets will turn loose of the Afghan tar baby, however, although they may try to engineer some changes at the top" ("Soviet-Afghan Relations", p. 2).According to the State Department, the Soviets were also concerned about how developments in Afghanistan would affect SALT II negotiations.

\section{State Department/US Embassy Reports}

Archives from the U.S. embassy, part of the State Department, in Kabul also focused on how domestic factors, such as Afghan leaders provoking the Islamic resistance movements (through unpopular policies), fermented the ingredients that would 
eventually provide the sparks that would lead to the Soviet invasion of Afghanistan ("United States Embassy: An Assessment of Soviet Influence and Involvement in Afghanistan", p. 6). They chronicle how the new Marxist-Leninist regime infuriated the majority of the citizens in this conservative society. Pushing for agricultural modernization and the rights of women was simply too much for this conservative society. The result of the cultural backlash against these Western reforms was the rise of an Islamic insurgency movement.

To deal with this opposition the Soviets urged the Afghan government to relax its reforms. The U.S. embassy in Kabul, reporting in September of 1979, argues that "the Khalqis have evidently been instructed by the Russians to tone down those aspects of their revolution which arose opposition” (“United States Embassy: An Assessment of Soviet Influence and Involvement in Afghanistan”, p. 6). For these reasons, Afghan leaders "declared (in mid-July of 1979) its land reform program successfully completed, thereby at least avoiding the creation of further opposition along the lines that this reform measure apparently had prompted” (“United States Embassy: Soviet Effort to Urge DRA to Find a Political Resolution of Domestic Conflict May be Underway”, p. 2). Other attempts to appease the opposition, according to the U.S. embassy, included declaring their literacy program a success as well as reducing the amount of agricultural land that would be seized from tribal leaders. Thus, the U.S. embassy in Kabul argued that political solutions, rather than military solutions were now the order of the day for the Afghan government and the Soviet Union.

Ultimately, report after report from the U.S. embassy in Kabul stressed the fact that the Soviets were extremely cautious in how they handled the Afghan insurgency. 
They did not seek an outright invasion. Even after the Islamic insurgencies were gaining ground, the Soviets still pushed for caution. Writing in May of 1979, a report entitled the "Soviet Role in Afghanistan", points out that while "Soviet involvement in Afghanistan has increased (advisors and arms) perceptively in recent weeks [it] has not yet reached the exaggerated levels reported in the world's press. Although there is a possibility that Soviet troops may intervene in this domestic conflict...the U.S.S.R. will probably avoid plunging into what could well become a Vietnam-type trap" ("United States Embassy: Afghanistan; Current Soviet Role in Afghanistan", p. 2). "United States Embassy: Afghanistan; Current Soviet Role in Afghanistan", the May of 1979 report cited above, also stresses that "in our opinion analogies with the Soviet invasion of Czechoslovakia are faulty. We think the Soviets will continue to increase their advisory and logistical military support for the pro-Soviet Kabul people.....and Moscow will probably avoid shouldering a substantial part of the anti-insurgency combat" ("United States Embassy: Afghanistan: Prospects for Soviet Intervention”, p. 1).

Another memo from July of 1979 suggests the Soviets were cautious in regard to nearby Pakistan. An article entitled "Soviet Effort to Urge DRA to Find a Political Resolution of Domestic Conflict May Be Underway" underscores suggests that "there has recently been a moderation in this government's (Afghanistan's) anti- SI Pakistan propaganda." Such a maneuver represented the Afghan government's, at Soviet urging, attempt to "avoid or draw back selectively from confrontation" ("United States Embassy: Soviet Effort to Urge DRA to Find a Political Resolution of Domestic Conflict May be Underway", p. 2). 
The U.S. Embassy in Kabul also understood that invading Afghanistan would place important Soviet foreign policy interests in jeopardy. "United States Embassy: Afghanistan: Prospects for Soviet Intervention", also argues that "a Soviet invasion of Afghanistan would probably [be] to the disadvantage of its global strategic interests. It would deal a blow to Détente with the West at a time when Moscow is increasingly preoccupied with the growing Chinese threat in the East" ("United States Embassy: Afghanistan: Prospects for Soviet Intervention", p. 2). The report suggests that invading Afghanistan would allow China and the U.S. to paint the Soviets as Third World aggressors that should not be trusted by countries in the less developed world. Finally, the report contends that the Soviets also could never obtain the same result in Afghanistan as in Czechoslovakia. The rural topography of the country and the rural nature of the resistance were cited by the U.S. as constraining factors. Interagency memorandums Defer to State Department during Late 1979

Besides the cautious analysis of the State Department and its embassy in Kabul, I find little interpretation of the events occurring in Afghanistan during the late 1970's by the CIA, DIA, and the NSC. They seem conspicuously silent on this matter. What I do find are several Interagency Intelligence memorandums (which obviously include the CIA, DIA, and the NSC) suggesting that the Soviets were trying to evade an invasion at all costs. Responding to the increasing revolutionary turmoil on its border, an Interagency Intelligence memorandum for September 14, 1979 argues that "Soviet leaders may be on the threshold of a decision to commit their own forces to prevent the collapse of the regime and protect their sizeable interests in Afghanistan" ("The Soviet Invasion of Afghanistan in 1979”, para. 5). However, they couched their analysis by stating that the 
Soviets would only do so in a gradualist fashion through the additional of some military advisors and small army units (“The Soviet Invasion of Afghanistan in 1979”, para. 7).

A subsequent Interagency memorandum, one that was actually commissioned by Brzezinski, concludes that "even if the current Afghan regime fractured and 'no viable Marxist alternative' emerged, 'rather than accept the political costs and risks of a massive Soviet invasion to fight the insurgency,' the Soviets 'would promote installation of a more moderate regime willing to deal with them"” ("The Soviet Invasion of Afghanistan in 1979", para. 11). The only way, according to the report, that the Soviets would invade would be if there was political chaos or if the Soviet-allied regime collapsed. Thus, while some elements of the U.S. bureaucracy disagreed over the reasons for the 1978 Marxistinspired coup, the entire U.S. intelligence community was in agreement in 1979 that the Soviets were trying the best they could to avoid an invasion. U.S. agencies were also in agreement that religious extremism/internal conflict in Afghanistan was a strong contributing factor for Soviet worry in Afghanistan. ("The Soviet Invasion of Afghanistan in 1979", para. 13).

\section{Soviet Documents and Afghanistan}

Recently declassified Soviet documents support the caution thesis. One such document, outlining a Communist Party of the Soviet Union Politburo Meeting on March 17, 1979, shows Soviet Premier Leonard Brezhnev and his Politburo colleagues going through painstaking means to avoid plunging the Soviet Union into an Afghan quagmire. They believed a Soviet invasion would run counter to Soviet foreign policy interests. For instance, Soviet leaders agreed that "all we have done in recent years with such effort in terms of détente, arms reduction, and much more-all that would be thrown back (should 
the U.S.S.R. invade Afghanistan). China, of course, would be given a nice present. All the non-aligned countries will be against us" ("Afghanistan: Lessons from the Last War document 1", para 7). Soviet caution is further reinforced in a meeting between Soviet Politburo members A.N. Kosygin, A.A. Gromyko, D.F. Ustinov, B.N. Ponomarev and Afghan Premier N.M. Taraki a few days later on March 20, 1979. The Politburo members unequivocally tell Taraki that:

The deployment of our troops in the territory of Afghanistan would immediately awaken the international community and would invite sharply unfavorable consequences. This would be a conflict with imperialist countries...Our mutual enemies are just waiting for the moment when Soviet forces appear on Afghan territory...the question of deploying forces has been examined by us from every direction... we came to the conclusion that that if our troops were introduced, the situation in your country would not only not improve but would worsen. Besides, as soon as our troops cross the border, China and all other aggressors will be vindicated. ("Afghanistan: Lessons from the Last War", document 3, para. 5).

Most importantly, Soviet leaders understood that the domestic internal politics of Afghanistan, such as the fact that the majority of the people supported the Islamic insurgency, prohibited the U.S.S.R. and the rebels from winning the hearts and minds of the Afghan people. Politburo members concurred that:

It's completely clear to us that Afghanistan is not ready at this time to resolve all the issues it faces through socialism. The economy is backward, the Islamic religion predominates and nearly all the rural population is illiterate....It is [in fact] under the banner of Islam that soldiers are turning against the government, and an absolute majority perhaps only with rare exceptions are true believers. ("Afghanistan: Lessons from the Last War", document 1, para. 8)

The internal dynamics of Afghanistan ultimately prevented the Soviet Union from achieving a clean and immediate victory through the use of a military invasion. A.A. Gromyko stated, with agreement from fellow Politburo members that the U.S.S.R. should 
"rule out such a measure as the deployment of our troops into Afghanistan...our army when it arrives will be considered the aggressor. Against whom will it fight? Against the Afghan people first of all and it will have to shoot at them" ("Afghanistan: Lessons from the Last War, document \# 1", para. 9). More so, information flowing to Soviet leaders at the time suggested the army and the Afghan people were switching their allegiances over to the rebels. Taraki even reported to Soviet leaders that "half the division located in Herat has gone over to the rebels" ("Afghanistan: Lessons from the Last War, Document $1 "$, para 16).

Therefore, while Soviet leaders agreed that Afghanistan "must not be surrendered to the enemy", they told Afghan Premier Taraki that "the most effective support we could give you would be through methods of our political influence through neighboring countries and through the rendering of extensive and manifold assistance. This would accomplish much more than through the deployments of our troops" ("Afghanistan: Lessons from the Last War, document \#3”, para. 22). Such caution in the face of Soviet leaders believing that "bands of saboteurs and terrorists from the territory of Pakistan, trained and armed not only with the participation of Pakistani forces but also of China, the U.S.A, and Iran" were aiding and abetting the Afghan insurgents speaks volumes about the about the persistent caution demonstrated by Soviet leaders when it came to situation in Afghanistan. (“Afghanistan: Lessons from the Last War”, document \# 1. para. 7)

\section{Section Conclusion}

The archival evidence points to a cautious Soviet Bloc in Afghanistan. State Department, U.S. embassy, and Soviet archives demonstrate that the Soviets did not push 
for the 1978 Marxist coup in Afghanistan. The Soviets also did not use this coup as an opportunity to expand their influence in the region (as the quantitative evidence in chapter three showed). Instead, the Soviets were grappling with religious extremists and trying to find a possible political solution to the events that were unfolding in Afghanistan. Chapter two's historical summary showed this to be the case. The Brzezinski-backed NSC disagreed with the initial State Department assessment of the 1978 coup. They contended that the coup was part of a Soviet drive towards the Persian Gulf. Nevertheless, they agreed with State Department during late 1979 that the Soviets were acting in a cautious manner. The U.S.S.R. was not seeking to invade Afghanistan and was doing all it could to avoid doing so.

Different theories would have different takes on this. Structural Marxists would argue that substantial evidence shows and will show the Soviets to be cautious in this region. For balance of threat realists, the Soviets were aggressive. These findings show this analysis as incorrect. As for domestic politics, at first glance it seems as though it is not useful in this section. However, supporters of domestic politics would argue that the seeds of interagency dissent were beginning to take hold in Afghanistan between the State Department and various other agencies. Indeed, supporters of domestic politics argue that they can show the more hawkish agencies pushing for covert action in Afghanistan and this undermining the initiatives of the State Department. I will, of course, evaluate this in the next chapter as this corresponds to U.S. actions in the region. 


\section{Soviets on the Defensive in Eastern Europe}

\section{Section Introduction}

The U.S. intelligence agencies seem to have been on the same page with regard to Eastern Europe. The State Department, CIA, DIA, and the NSC (and President Carter) all agreed that the "worker's riots of June 1976 in Poland were especially unsettling to Moscow" ("Soviet Goals and Expectations in the Global Power Arena", p. 33). "Soviet Goals and Expectations in the Global Power Arena (NIE 11-4-78)", further argues that economic problems in other Warsaw Pact countries had drastically affected Moscow. In fact, the interagency analysis finds that "in recent years, the Soviets have seen the economic burdens associated with maintaining their position in Eastern Europe grow, as communist countries in the area consumed subsidized energy resources that could otherwise be exchanged for hard currency" ("Soviet Goals and Expectations in the Global Power Arena", p. 33). Indeed, the weakening of Eastern Europe is precisely what I discovered in chapter three.

The unclassified documents from the CIA and National Security Advisor Brzezinski are the most telling, however. Indeed, newly released CIA documents from the Directorate for Intelligence, such as "Soviet Objectives and Tactics at the Belgrade Conference" (1977) and "Dissident Activity Inside Eastern Europe" (1977), from National Security Advisor Brzezinski, such as "Prospects for Eastern Europe" (1977), and from President Carter, such as "Policy for Eastern Europe" (1977), all suggest the Soviet Bloc was on the defensive in Eastern Europe during the last few years of Détente. Western exploitation of the human rights issue in Eastern Europe, growing 
disenchantment with Western European parties, and growing economic problems were all highlighted by these reports as growing problems for the Soviets.

\section{Misjudging Human rights}

To understand the human rights issue one must go back to the Helsinki conference of 1975. This conference etched into agreement the "idea that the U.S.S.R. had a legitimate right to participate in the resolution of "all European issues," that is a right to be heard in the councils of Western Europe as well as those of the East" (Soviet Objectives and Tactics at the Belgrade Conference, p. 2). In return, the Soviets "pledged to respect human rights and fundamental freedoms" in Eastern Europe and allow increased interchange between East and West ("Soviet Objectives and Tactics at the Belgrade Conference", p. 3). The Soviets also gave ground on the prior notification of major military maneuvers through the deployment of confidence-building measures while the West agreed to provide the U.S.S.R. with its "coveted technology" ("Soviet Objectives and Tactics at the Belgrade Conference", p. 3).

However, "Soviet Objectives and Tactics at the Belgrade Conference" contends that the "Soviets misjudged the impact of human rights provisions of the Helsinki agreement in Eastern Europe and at home" ("Soviet Objectives and Tactics at the Belgrade Conference", p. 1). Legitimizing the idea of increased interchanges with the West posed severe problems for the Soviet Bloc's authoritarian control mechanisms. After all, an increasing amount of worker unrest, rioting, and dissident intellectual activity in Poland had begun to spread since the Helsinki accords ("Soviet Objectives and Tactics at the Belgrade Conference", p. 4) The CIA's "Dissident Activity in Eastern Europe" went so far as to characterize the situation in the country as volatile ("Dissident 
Activity in East Europe", p. 3). Eastern Germany, the border state between East and West, also witnessed growing "restiveness among workers in complaints about working conditions" ("Dissident Activity in East Europe", p. 3). Unrest also was brewing in Czechoslovakia and other Eastern European states ("Dissident Activity in East Europe", p. 3).

\section{Disenchantment with Western Europe}

The other side of the human rights coin, Moscow's hope that opening up internally would allow for a closer working relationship with Western European left-ofcenter political parties, also failed to come into fruition. The CIA's "Dissident Activity in Eastern Europe" argues that Eurocommunist parties in Western Europe were actually extending "verbal aid and comfort to East European and Soviet dissidents" ("Dissident Activity in East Europe", p. 2). In the end, left-of-center parties were simply unwilling push forward the socialist agenda without the inclusion of political freedom. Even more worrisome for the Soviet Bloc was the fact that Eurocommunism itself was gaining "appeal within the ruling parties in Eastern Europe" ("Dissident Activity in East Europe", p. 2).

\section{U.S. Economic Warfare}

That was not the end of Soviet problems. "Prospects for Eastern Europe", written by National Security Advisor Brzezinski, plays up the issue of the U.S. exploiting economic problems in Eastern Europe. In fact, taking advantage of these economic problems (in order to pull Eastern Europe away from the U.S.S.R.), through more trade, was the subsequent order of the day for U.S. policy. The Soviets could do little but "acquiesce or even encourage such expansion because they were reluctant to subsidize 
the East European economies” (“Prospects for Eastern Europe”, p. 1). Brzezinski’s view was supported by President Jimmy Carter. Presidential Directive NSC-21 lays out Carter's policy toward Eastern Europe. He outlines his support for a strategy of supporting Eastern European nations that "are either relatively liberal internally or relatively independent internationally" ("Policy Toward Eastern Europe", p. 1). President Carter also pledges support to Poland and Romania, specifically to Poland due to its large debts to the West and argues in favor of a trade treaty with Hungary.

Overall, "Prospects for Eastern Europe" nicely summarizes (and supports) the cumulative findings of the U.S. intelligence community. According to this report, destabilizing factors for the U.S.S.R. in Eastern Europe in 1977 included "détente (human rights), slower economic growth, and dissident activity" ("Prospects for Eastern Europe", p. 1). The report admits that dissident activities in Poland (with its large scale dissident movement) and Eastern Germany (moderate dissident) activity could result in significant problems for the U.S.S.R.

\section{Section Conclusion}

These findings run counter to the arguments made by balance of threat realists that U.S. aggression in the early 1980's was a result of unrestrained Soviet aggression. U.S. aggression at a time when the Soviet Bloc was cautious simply diminishes balance of threat theory. Structural Marxism comes out ahead once again. They would argue that there is clear evidence the U.S. was very aggressive in trying to weaken the U.S.S.R. in its most important sphere of influence. 
Détente, the Third World, and Strategic Nuclear Arms

\section{Section Introduction}

Herein I pursue two goals. My first goal was to search U.S. archives to understand why Détente collapsed. Was revolutionary conflict in the less developed world, and thus the Soviet contribution to that conflict, the primary or secondary reason for Détente's collapse? After all, some asymmetrical realist scholars argue that Soviet gains in the strategic nuclear arms race was the most significant factor in Détente's disintegration. In their view, revolutionary turmoil was only a contributing factor.

Overall, the archival evidence points to Soviet actions in the less developed world as the primary reason for Détente's collapse. Declassified documents from the State Department, Defense, and from President Jimmy Carter contend that this was the case. In addition, U.S. archives uphold the view that Soviet actions in the strategic nuclear arms race were defensive in nature. However, some agencies (such as Defense and NSC) were worried about some significant Soviet improvements in the strategic arms balance of power. Regardless, the U.S. archival evidence from 1978 and 1979 still shows moderate support for continuing SALT II negotiations.

\section{The Third World}

State Department archival records argue that the disintegration of Détente can be firmly tied to events in the less developed world. One such report, published under the Under Secretary for Public Diplomacy and Public Affairs, argues that:

By 1974, strains on bilateral relations had already compromised U.S. support for Détente and the crisis in Angola served to accelerate this trend. From the U.S. point of view, one of the aims of Détente was to draw the Soviet Union further into the international system so that Washington could induce Moscow to show 
restraint in its dealings with the Third World. The Ford Administration believed that Cuba had intervened in Angola as a Soviet proxy and as such, the general view in Washington was that Moscow was breaking the rules of Détente. The appearance of a Soviet success and a U.S. loss in Angola on the heels of a victory by Soviet-supported North Vietnam over U.S.-supported South Vietnam

continued to erode U.S. faith in Détente as an effective Cold War foreign policy. The U.S. failure to achieve its desired outcome in Angola raised the stakes of the superpower competition in the Third World. Subsequent disagreements over the Horn of Africa, and Afghanistan contributed to undoing the period of Détente between the Soviet Union and the United States. ("Angola 1974-1975", para 6.)

This argument is also promoted by another State Department report entitled Détente and Arms Control 1969-1979. This report contends that:

Overblown expectations that the warming of relations in the era of Détente would translate into an end to the Cold War.... created public dissatisfaction with the increasing manifestations of continued competition and the interventions in the Third World. By the time the Soviet Union invaded Afghanistan in 1979, the spirit of cooperation had been replaced with renewed competition and formal implementation of the SALT II agreement stalled. ("Détente and Arms Control 1969-1979”, para. 4)

Thus, State Department archives firmly contend that Soviet actions in the less developed world, specifically in Angola, the Horn of Africa, and Afghanistan, were responsible for the collapse of Détente. Even more significantly, State Department records argue that Soviet activity in the less developed world was responsible for the collapse of SALT II negotiations. As a result, I can argue that Soviet activity in/revolutionary activity in the less developed world was much more significant to Détente's collapse than Soviet-U.S. competition in the strategic nuclear arms race.

The Carter administration also blamed events in Afghanistan for the deterioration of Soviet-American relations in 1980. "Current Foreign Relations”, a State Department document summarizing Carter's policy positions, suggests this was the case. Indeed, as a 
result of Soviet actions in the less developed world, Carter pushes to permanently shelve SALT II talks (“Current Foreign Relations”, p. 3). President Carter was simply adhering to Kissinger's concept of linkage.

\section{Strategic Arms}

Despite the fact that Soviet activity in the less developed world is consistently cited as the strongest reason for the collapse of Détente and the deterioration of U.S.Soviet relations it is important to analyze U.S.-Soviet relations in the strategic nuclear realm since it can certainly bring in some important insights. After all, some realists argue that the most important aspect of the balance of power was none other than strategic arms. The U.S. intelligence agency archival reports in regards to strategic nuclear weapons during the late 1970's disagree with this view and suggest that the Soviets were on the defensive.

\section{State Department View}

An August 1977 report from the State Department, entitled "Soviet-U.S.

Relations: A Sixth Month Perspective", maintains that there is evidence that Soviet "suspicions and doubts about Carter policies explain to a large extent the defensive-andrelatively-stand-pat-positions they (Soviets) have adopted during this period" ("SovietU.S. Relations”, p. 1). Such positions and doubts, according to this report, were caused by a significant reversal in U.S. SALT policy. No longer was the U.S. adhering "to the détente formulas that shaped relations over the preceding five-year period-acceptance of nuclear parity, moderation of differences, etc" ("Soviet-U.S. Relations”, p. 1). On the contrary, U.S. policy "signified a new set of priorities, with the U.S. attempting to impose its view of these issues on the Soviet Union" ("Soviet-U.S. Relations”, p. 1). A new U.S. 
approach is why the State Department reported in May of 1977 that "the prevailing mood in the Kremlin is one of resentment at the evolution in U.S. policy toward the Soviet Union" (“Soviet Military Leaders Take a Tougher Line in V-E Day”, p. 4). Regardless of these feelings, the State Department knew that an influential cadre of Soviet leaders still "clung to the hope of Soviet-American cooperation on a fairly broad basis and the cutting of Moscow's defense expenditures" ("Soviet Military Leaders Take a Tougher Line in VE Day”, p. 4).

Understanding that the Soviets were cautious is why the State Department was very supportive of the SALT II talks. In a mid-1979 analysis entitled "The Mathematics of SALT" the State Department concludes that "the current rough parity between the capabilities of the U.S. and Soviet strategic forces will continue through SALT II" ("The Mathematics of SALT", p. 9). Rather than suggesting that SALT II would bog the U.S. down and give the Soviets the upper hand in the strategic nuclear forces arena, as suggested by the other agencies, the State Department report argues that:

In terms of overall capability, the new systems that both sides will deploy during the period will more than compensate for the required force reductions. Moreover, on the Soviet side at least, most of the dismantled weapons will be converted to other military uses. Nevertheless, the intercontinental attack capabilities of each side will be less than they would have been without the required reductions - and much more extensive reductions will be required of the Soviets than of the U.S. On the Soviet side, the number of SNDV's and MIRV capable launchers will be about 30\% less than expected in the absence of SALT. ("The Mathematics of SALT", p. 9)

Overall, the State Department reports appreciated the defensive position of the Soviet Union. They understood the fears of the Soviet Bloc. These fears included: 
growing U.S. public and congressional advocacy of a harsher policy toward the U.S.S.R....providing the U.S. with time and arguments for considering new arms programs which, if carried out, would pose even greater military and economic challenges for Moscow in the future. Furthermore, speculation about a variety of new U.S. advanced weapons projects were growing, feeding Soviet uneasiness about the prospects for holding on to parity. ("A Turn in U.S.-Soviets Relations", p. 6)

All in all, the State Department viewed Soviet actions as cautious. Considering that U.S. policy had turned a bit more assertive, as the State Department acknowledges above, they understood that the strategic situation improved in the U.S.'s favor.

Other Agencies (Mostly) Agree

Such a view was largely supported (at least in regard to strategic parity) by other U.S. intelligence agencies such as the CIA, NSC, and the Defense Department. These U.S. agencies, in a report entitled "Soviet Capabilities for Strategic Nuclear Conflict through the Late 1980's" (February 1978 version), did argue that, "Soviet forces for intercontinental attack will become more powerful and flexible. Even under constraints along the lines being negotiated in SALT. Soviet intercontinental offensive strength will grow in relation to that of the U.S. between now and the early 1980's" ("Soviet Capabilities for Strategic Nuclear Conflict Through; the Late 1980s", p. 9).

However, the report goes on to say that "the actual strategic significance of increases in Soviet striking power is debatable, especially in view of the many Soviet vulnerabilities and the retaliatory power of the U.S." ("Soviet Capabilities for Strategic Nuclear Conflict Through the Late 1980s”, p. 11) After all, the National Intelligence Estimate report firmly states that "under SALT conditions, advantages remain mixed" (“Soviet Capabilities for Strategic Nuclear Conflict through the Late 1980s", p. 10). The reasons for the "mixed" advantages were the fact that the U.S. possessed several 
significant advantages themselves. For starters, the U.S.S.R. was simply "unable to prevent U.S. alert bombers and at-sea SLBM's from being launched" ("Soviet Capabilities for Strategic Nuclear Conflict through the Late 1980s”, p. 10). Soviet defenses against other threats, such as cruise missile and short-range attack missiles were also considered as low.

These views were slightly modified by the next year. The CIA's National Intelligence Estimate of March $7^{\text {th }} 1979$ (signed off by all the intelligence agencies), also entitled "Soviet Capabilities for Strategic Nuclear Conflict through the Late 1980's", notes that "evidence acquired during the past year indicates some near-term Soviet advances will be greater than previously anticipated" ("Soviet Capabilities for Strategic Nuclear Conflict through the Late 1980's Version II", p. 1). "Soviet Capabilities for Strategic Nuclear Conflict through the Late 1980's" also states that the Soviets had already modified ICBMs and MIRVs (improving accuracy of missiles), which in the prior National Intelligence Estimate's analysis, was not suppose to occur "until the advent of new ICBMs several years later" ("Soviet Capabilities for Strategic Nuclear Conflict through the Late 1980's Version II", p. 2). The report also argues that the Soviets increased their production speed for research and development for submarines.

However, this National Intelligence Estimate reports still argued that Soviets efforts were largely defensive. Not only did the Soviets realize that they "faced mounting economic problems and leadership transition," they were also aware that the U.S. and NATO were considering "several important military options which are as yet undecided" ("Soviet Capabilities for Strategic Nuclear Conflict through the Late 1980's Version II", 
p. 24). For these reasons, the Soviet Bloc was determined to sign off on SALT II in an effort to reduce the possibility that the U.S. would augment their defense efforts.

The final National Intelligence Estimate report entitled "Soviet Capabilities for Strategic Nuclear Conflict" also showed considerable support for SALT II. The report argues that this agreement would reduce Soviet delivery vehicles by $15-30 \%$ and force the Soviets to replace certain weapons instead of deploying them as follow-ons. The National Intelligence Estimate report even claimed that SALT II would "reduce certain uncertainties about the future size and composition of those Soviet forces which were limited" ("Soviet Capabilities for Strategic Nuclear Conflict through the Late 1980's Version II", p. 25).

There is also additional evidence, despite public rhetoric, that several key officials in the Defense community showed support for SALT II in the Carter Administration. Documents from the Carter administration suggest this was the case. "The Case for SALT" shows that the "the Secretary of Defense, the Joint Chiefs of Staff, and the Commander of SAC believed that we [the USA] had a better chance of maintaining strategic equivalence with SALT II than without it" ("The Case for SALT", p. 4). These key figures cited several reasons. Such reasons included the fact that SALT II did not bar the U.S. from finishing the production of certain key strategic weapons as well as SALT II's limits on Soviet IBCMs and MIRVS. Ultimately, military officials did inform the Carter administration of their support for verification measures.

\section{Section Conclusion}

This section on the Third World and strategic arms has shown that events in the less developed world are what caused much alarm for U.S. policymakers. Détente did not 
collapse because the Soviets made gains in the strategic arms race. There is no credible archival evidence this was the case. There is substantial archival documentation (rhetorical evidence) that Détente collapsed because of Soviet aggression in the less developed world. They simply violated the policy of linkage that Kissinger had previously established.

These findings lead to a conundrum however. My analysis of U.S. archives has already shown that the Soviet Bloc was not aggressive in the less developed world during the late 1970's. The Soviets were not able to significantly overturn the balance of power. So how could it be that the U.S. became aggressive and blamed the Soviets for conflict in the less developed world when their own archives argue against this view?

Structural Marxists would argue that the U.S. was simply unleashing political rhetoric against the Soviets. They knew the Soviets were not aggressive in the less developed. The analysis of U.S. archives has shown this to be the case. However, because the U.S. was intensely worried about revolutionary activity in the less developed world the U.S. still went ahead and blamed the Soviets for it. For those that adhere to bureaucratic politics, they would point to evidence, which will be shown in the next chapter, which shows certain elements (Team B) of the U.S. pushed to suggest that the Soviets were aggressive in the strategic arms race.

\section{Conclusion}

My regional analysis examination has shown that the Soviets were primarily a cautious superpower in the Third World during the late 1970's. The U.S. archives (and in some cases Cuban and Soviet documents) confirm my findings from the previous chapters. The balance of power did not tilt in favor of the Soviet Bloc. Neither in the 
most vital areas of the world or those that were considered to be less vital to U.S. interests, do I find evidence suggesting that the Soviet Bloc was overturning the established balance of power.

The section on Asia shows that the Soviets were having a hard time in this region during the late 1970's. The State Department, the NSC, President Carter, and Brzezinski argued that the U.S. balance of power position, primarily in the military realm, had significantly improved during the late 1970's. The Sino-Soviet split was judged to be a huge nuisance for the U.S.S.R. This perfectly matches my findings from the previous historical and quantitative chapters. I also found that the rise of ASEAN, as argued by the State Department, was a significant development that injured Soviet interests in the region. ASEAN grouped together the remaining nations in Southeast Asia into a potent Western economic bulwark against Soviet aggression. The Defense Department, however, did provide a dissenting viewpoint. They argued that the naval balance of power was in danger. Citing Japanese apprehension, they suggested that the U.S. needed to do more in this area.

Searching through the U.S. archives relating to the Middle East, I also found large-scale evidence suggesting the Soviet Bloc did not make gains in the area of the world considered the most vital to U.S./Western interests. U.S. archives showed that the U.S. made significant improvements in this area of the world. Documents from all U.S. agencies also argued that the rise of the oil-producing states (Saudi Arabia and Iran) and Soviet failings to counter Israeli influence through the Palestinian Liberation Organization were major setbacks to Soviet efforts. Finally, in regard to Soviet gains the Horn of Africa and Yemen, U.S. archives described these as "poor compensation for their 
losses" in the region ("Soviet Goals and Expectations in the Global Power Arena", p. 52). These findings corroborate my historical and quantitative findings from the previous chapters.

The examination of Sub-Saharan Africa yields an interesting outcome. They show the State Department and the NSC suggesting that the Soviets were not aggressive with their aid towards Angola in the early part of 1975 (as chapter three showed). They suggest the Soviets had no long-term interests and were only helping to equalize the MPLA with its competitors. However, once the MPLA achieves victory, these agencies blast the Soviets as aggressive. Nevertheless, Soviet and Cuban archives show that Cuban helped instigate the conflict. Content on providing limited amounts of military weapons in order to please local allies, the Soviets did everything in their power to avoid getting involved in a protracted conflict. In fact, some U.S. archival hints at the possibility (as suggested by Peter Gleijeses when studying Cuban archives) that the battle in Angola could be characterized as a North-South conflict between the U.S./West and Cuba. They argue that Cuba had their own political and strategic interests at stake in pushing for war. My study of Latin America, probably the most vital area of the less developed world for the U.S., also points away from Soviet aggression during the late 1970's. As chapter two asserted, the Soviets did not make significant gains here. Documents from the U.S. actually attribute the rise of Latin American nationalism to large-scale poverty, repression in the region, and the political rise of the middle classes. In fact, these documents show U.S. policymakers (from the CIA, State, and DIA) agreeing that Soviet gains in the region came only because of U.S. errors. The policies of the U.S. were exacerbating these internal dynamics leading to a sharp rise in nationalism in the region. 
The U.S. archives also show that the Soviets (or Cuba) did not provide significant assistance to the Sandinistas prior to their revolution. The bulk of Soviet assistance to Latin America, as traced by my findings in Chapter three, were recognized by U.S. sources as Soviet assistance to Angola in Sub-Saharan Africa.

By and large, Latin America received a "lower Soviet priority" than other areas of the less developed world. Such Soviet caution correlates with the quantitative evidence in chapter three ("Soviet Goals and Expectations in the Global Power Arena", p. 38). Ultimately, U.S. intelligence agencies documented that "Moscow's diplomatic posture since the fall of Chilean President Allende is fundamentally one of watching and waiting" ("Soviet Goals and Expectations in the Global Power Arena", p. 38).

Finally, my regional analysis concluded with the study of Afghanistan. This section demonstrated that the Soviet Bloc did not strive for aggression during the late 1970's. State Department, U.S. embassy, and Soviet archives corroborate to show that the Soviets did not push for the 1978 Marxist coup in Afghanistan. The Soviets also did not use this coup as an opening to expand their influence in the region. Instead, documents from the U.S. embassy (Soviet archives as well) show U.S. comprehension in regard to how the local internal dynamics, such as the clumsy modernization policies of the Sovietbacked local regime, were the driving force behind Soviet concerns. The Soviets were grappling with religious extremists and trying to find a possible political solution to the events that were unfolding in Afghanistan.

The Brzezinski-backed NSC disagreed with the initial State Department assessment of the 1978 coup. They contended that the coup was part of a Soviet drive towards the Persian Gulf. Nevertheless, they agreed with State Department during late 
1979 that the Soviets were still acting in a relatively cautious manner. The U.S.S.R. was not seeking to invade Afghanistan and was doing all it could to avoid doing so.

The Soviets were even on the defensive in Eastern Europe. National Security Advisor Brzezinski backs up the cumulative findings of the U.S. intelligence community. He argues that "slower economic growth and dissident activity due to the" were putting the Soviets on the defensive in their own backyard ("Prospects for Eastern Europe", p. 1). This point of view was backed up by the State Department and by President Carter. The quantitative evidence in chapter three also found this to be the case.

Without a doubt, the regional analysis has shown that the Soviets did not make substantial gains in the less developed world during the late 1970's. Backing up these findings, U.S. intelligence agencies summarized in mid-1978 that Soviet foreign policy simply reflected:

A purposeful, cautious exploration of the political implications of the U.S.S.R.'s increased military strength. Soviet policy will continue... On the whole such a prognosis, while projecting some increase in the assertiveness of Soviet external behavior, represents a fairly natural evolution of the U.S.S.R.'s foreign policy. The changes from past behavior are gradual and unbroken, and are rooted in the basic perceptions and values that have long informed Soviet policy. ("Soviet Goals and Expectations in the Global Power Arena", p. x)

Such statements suggest that U.S. agencies firmly understood the context of Soviet behavior during the late 1970's. U.S. agencies believed, corroborating my foreign aid quantitative findings from chapter three, that Soviet behavior was cautious and gradual and would continue at the same pace into the early 1980's. Subsequent U.S. suggestions that the Soviet Bloc was aggressive in the late 1970's do not carry any weight. Assertions to the contrary are not substantiated by the overall thrust of U.S. archives. 
For now, chapter four has shown once again that structural Marxism possesses an advantage over balance of threat realism. There is simply overwhelming evidence suggesting U.S. decision-makers believed Soviet actions were cautious in the less developed world. Still, evidence is also coming in for bureaucratic politics. Dissent from more hawkish U.S. intelligence agencies in Asia and Afghanistan has been discovered. How strong was this dissent? To better answer this question, as well as continue to test structural Marxism and balance of threat realism, I shall now turn towards the U.S. archives pertaining to the U.S. response and U.S. actions during Détente. 


\section{REFERENCES}

"A Brief Chronicle of Events in Angola" (SA00484); Records of the State Department; 1975; National Archives at College Park, College Park, MD

"Aid to Nicaragua Since the Revolution" (Limited Official Use Managua 1639); Records of the U.S. Treasury Department; March 1982; Jimmy Carter Presidential Library, Atlanta GA.

"Afghanistan: Lessons from the Last War"; National Archives at College Park, College Park, MD. Retrieved August 10, 2008 from:

http://www.gwu.edu/ nsarchiv/NSAEBB/NSAEBB57/soviet.html

"Angola 1974-1975"; Records of the State Department; Retrieved January 2007 from: http://www.state.gov/r/pa/ho/time/dr/91727.htm

"Approaches to Dealing with the Soviet Union and The Soviet Union" (CH00396); Records of the National Security Council; December 2, 1975; National Archives at College Park, College Park, MD

“A Turn in U.S.-Soviets Relations: Nine Months' Gestation" (SE00508); State Department (Bureau of Intelligence and Research) Report; November 1, 1977; National Archives at College Park, College Park, MD

Bender, G. (1978). "Kissinger in Angola: Anatomy of a Failure". Retrieved June 2008 from http://www-rcf.usc.edu/ bender/pdfs/article13.pdf

Brzezinski. Z. (1983). Power and Principle: Memoirs of the National Security Adviser, 1977-1981, Farrar, Strauss, and Giroux

Carter, J. (1982) Keeping the Faith. Bantam Books

"Changes in the Middle East: Moscow's Perceptions and Options" (IR02628); Secret Report from the CIA Foreign Assessment Center; p. iii (follow bullet points); June of 1979; National Archives at College Park, College Park, MD

"Cuba-Nicaragua: Support for Central American Insurgencies" (EL00032); Record of the CIA; June 20, 1980; National Archives at College Park, College Park, MD

"Cuba-Nicaragua: Support for Central American Revolutionaries: The First Six Months' (EL00021); Record of the CIA; January 15, 1980; National Archives at College Park, College Park, MD 
"Cuban Intervention in the Third World" (NLC 24-15-4-1-4); Sometime in 1980 (Date Unclear); Records of the National Security Council; P. 1Jimmy Carter Presidential Library, Atlanta, GA.

"Country Analysis and Strategy Paper: Guatemala" (GU00477); Records of the CIA; May 30, 1973; National Archives at College Park, College Park, MD

“Current Foreign Relations" (AF00778); Records of the State Department; January 9, 1980; National Security Archives, Washington, DC.

"Détente and Arms Control 1969-1979"; Records of the State Department; Retrieved from January 2007 from: http://www.state.gov/r/pa/ho/time/dr/104269.htm

"Discussion of U.S. policy and Soviet Involvement in Angola" (SA00483); Records of the State Department; 1975; National Archives at College Park, College Park, MD

"Dissident Activity in East Europe" (NLC 7-17-5-5-7); Secret CIA Report; April of 1977; Jimmy Carter Presidential Library, Atlanta GA

"El Salvador: The Potential for Violent Revolution" (NLC 6-74-2-28-3); Record of the National Foreign Assessment center of the CIA; October 1977; Jimmy Carter Presidential Library, Atlanta GA

Gleijeses, P. (2003). Conflicting Missions: Havana, Washington and Africa, 1959-1976. University of North Carolina Press.

"Implications to Japan of Soviet Use of Vietnamese Bases" (JA00539); Records of the U.S. Department of State, p. 2; May 11, 1979; National Archives at College Park, College Park, MD

"Japan in the Middle East" (JA00522); Secret report of the National Security Council; April 24, 1979; National Archives at College Park, College Park, MD

"Northeast Asia Balance: Summary" (JA00449); Secret Records of the U.S. Department of Defense; October 20, 1978; National Archives at College Park, College Park, MD

"NSSM-224 United States Policy Toward Angola" (PR01307); Records of the National Security Council; June 18, 1975; National Archives at College Park, College Park, MD

Pastor, R. (1992). The Carter Administration and Latin America: A Test of Principle; The Carter Center. 1992.

"Policy toward Eastern Europe" (PR01363); Presidential Directive from Jimmy Carter to Walter Mondale (and all U.S. Intelligence Agencies); September 13, 1977; Jimmy Carter Presidential Library, Atlanta GA 
"Prospects for Eastern Europe" (NLC 6-22-1-5-5); Secret memorandum from Brzezinski to President Jimmy Carter; June 24, 1977; Jimmy Carter Presidential Library, Atlanta GA

"SALT, Soviet-U.S. Relations, Angola, Cuba, Africa, PRC, TTBT/PNE"; Records of the State Department; April 1, 1976; National Security Archives, Washington DC Une Odyssee Africaine. 2006. Directed by: Jihan El Tahri.

"SCC Meeting on Central America" (EL01326); Secret Report from the White House; July 20, 1979; National Archives at College Park, College Park, MD

"Security Issues at the Meeting between Prime Minister Fukuda and President Carter" (JA00379); Secret Cable from Ambassador Sherman William to U.S. State Department; April 29, 1978; National Archives at College Park, College Park, MD

"Southeast Asia" (JA00552); Records of the U.S. Department of State; June 4, 1979; National Archives at College Park, College Park, MD

"Soviet Capabilities for Strategic Nuclear Conflict through the Late 1980s" (SE00509); Secret National Intelligence Estimate Led By the CIA; February 21, 1978; National Archives at College Park, College Park, MD

"Soviet Capabilities for Strategic Nuclear Conflict through the Late 1980s" (SE00519); Secret National Intelligence Estimate Led By the CIA; March, 7, 1979; National Archives at College Park, College Park, MD

"Soviet Goals and Expectations in the Global Power Arena' (NIE 11-14-78); Records of the CIA; April 23, 1978; Jimmy Carter Presidential Library, Atlanta GA The Soviets in Latin America: Trends and Prospects; Secret Report from the State Department; January 25, 1980; National Archives at College Park, College Park, MD

"Soviet Interest in Latin America" (NLC 24-7-8-0); Records of the CIA; April 4, 1977; Jimmy Carter Presidential Library, Atlanta GA

"Soviet Objectives and Tactics at the Belgrade Conference" (NLC 28-5-4-1-1); Secret CIA Report; May of 1977; Jimmy Carter Presidential Library, Atlanta GA

"Soviet Military Deliveries to Cuba in 1979 and Trends in 1980" (NLC 23-54-10-3-3); Records of the CIA; March 1980; Jimmy Carter Presidential Library, Atlanta GA.

"Soviet Military Leaders Take a Tougher Line in V-E Day" (SE00504); State Department (Bureau of Intelligence and Research) Report; May 27, 1977; National Archives at College Park, College Park, MD 
"Soviet Military Policy and Posture in the Third World" (SE 00470); Records of the CIA; August 2, 1973; National Archives at College Park, College Park, MD

"Soviet Strategic Objectives" (NIE 11-1-77); Records of the CIA; January 1977; Jimmy Carter Presidential Library, Atlanta GA

"Soviet-Afghan Relations: Is Moscow's Patience Wearing Thin" (AF00560); Records of the State Department memorandum; p. 2; May 24, 1979; National Archives at College Park, College Park, MD

"Soviet-U.S. Relations: A Sixth Month Perspective" (SE00506); State Department (Bureau Intelligence and Research) Report; August 15, 1977; National Archives at College Park, College Park, MD

"Special Sensitive memorandum Regarding the Response to NSSM-24" (PR01308); Records of the State Department; June 25, 1975; National Archives at College Park, College Park, MD

"The Afghan Coup" (AF00268); Secret memorandum from Harold Saunders to Secretary of State Cyrus Vance"; April 28, 1978; National Archives at College Park, College Park, MD

"The Case for SALT"; Carter administration Document; December 6, 1979; White House Files; Filed under Butler/ Chief of Staff; Box 128; 12/6/79- 4/14/1980; Jimmy Carter Presidential Library, Atlanta GA

"The Cuban- Soviet Relationship" (NLC 12-19-1-9-8); (Date Unclear); Jimmy Carter Presidential Library, Atlanta, GA.

"The Mathematics of SALT" (SE00524); State Department (Bureau of Intelligence and Research) Report; June 14, 1979; National Archives at College Park, College Park, MD

"The Situation in Nicaragua" (NLC 6-56-7-31-3); Records of the CIA; October 1979; Jimmy Carter Presidential Library, Atlanta GA.

"The Soviet Invasion of Afghanistan in 1979: Failure of Intelligence or of the Policy Process?"; George Washington University; Working Group Report 111; September 26, 2005. Retrieved May 2008 from: http://isd.georgetown.edu/Afghan_1_WR_group.pdf

"The Soviet Role in Asia" (AF01504); Records of the U.S. Department of State, Bureau of Public Affairs (No. 521); October 19, 1983; National Archives at College Park, College Park, MD 
"The Soviet Union; Europe; The Middle East; South Asia; Angola"; Records of the National Security Council; December 3, 1975; National Archives at College Park, College Park, MD

"Threat of a Leftist Extreme Makeover in El Salvador" (EL00023); Record of the CIA; January 3, 1980; National Archives at College Park, College Park, MD

"U.S./Japan-USSR Balance" (JA00402); Secret Records of the U.S. Department of Defense; June 12, 1978; National Archives at College Park, College Park, MD

Une Odyssee Africaine. 2006. Directed by: Jihan E1 Tahri.

“United States Embassy. Afghanistan' (AF00546); Current Soviet Role in Afghanistan; Secret Memo Bruce Amstrutz to U.S. Department of State; May 9, 1979; National Archives at College Park, College Park, MD

"United States Embassy: Afghanistan" (AF00558): Prospects for Soviet Intervention; From Malcolm Toon to U.S. Department of State; May 24, 1979; National Archives at College Park, College Park, MD

"United States Embassy" An Assessment of Soviet Influence and Involvement in Afghanistan" (AF00633); Records of the State Department; National Archives at College Park, College Park, MD

"United States Embassy: Soviet Effort to Urge DRA to Find a Political Resolution of Domestic Conflict May be Underway" (AF00585); July 18, 1979; Secret Memo From Bruce Amstutz to U.S. Department of State; National Archives at College Park, College Park, MD

"U.S. National Strategy" (PD01509); Top Secret Presidential Directive (to State and Defense); August 24, 1977; National Archives at College Park, College Park, MD

"U.S.-Soviet Relations and SALT" (JA00556); For Summit Meeting Between President Carter and Prime Minster Ohira; June 4, 1979; National Archives at College Park, College Park, MD

"U.S. Strategy in Asia: Trends, Issues, and Choices" (JA01958); From Policy Planning Staff (Winston Lord) to the Secretary of State (Kissinger); Records of U.S. Department of State, October 16, 1975. National Archives at College Park, College Park, MD

Vance, C. (1983). Hard Choices: Critical Years in America's Foreign Policy. Simon and Schuster

"Your Meeting with Ganri Yamashita" (JA00428); Secret Records of the Defense Department; August 16, 1978; National Archives at College Park, College Park, MD 
Chapter V: U.S Archives and the U.S. Response to the Soviet Threat in the Third World during the 1970's

\section{Introduction}

I now follow up and examine the archival documents pertaining to U.S. actions vis-à-vis the Soviet Union in the less developed world during the 1970's. Taking into account the cautious and defensive nature of Soviet actions during the middle-to-late 1970 's, as discovered in the previous chapter, I will now seek to analyze the actions of the U.S./West in the less developed world during the final years of Détente. As in chapter four, I use the records from the Carter Administration, as well as those from U.S. intelligence agencies, in an attempt to interpret how U.S. policymakers viewed the international security environment.

Balance of threat realism argued that the U.S. turned hostile during the 1980's against the Soviet Bloc due to the fact that the Soviets became aggressive in the less developed world during the middle-to-late 1970's. In fact, balance of threat realism traces Soviet aggression to the emerging power vacuum in the less developed world at the time due to the rise of nationalist movements in the less developed world. While these movements may have been independent of the Soviet Bloc when it came to their original growth, balance of threat realism suggested that a rival superpower, such as the U.S.S.R., would try everything in their power to secure these gains. They would surely exploit the emerging power vacuum.

Nonetheless, the quantitative and archival evidence in the previous chapters have begun to weaken the theory of balance of threat realism. Since the evidence points to significant Soviet caution during this time, it is probably time to begin to dismiss balance 
of threat realism. However, I shall continue to test this theory by analyzing the U.S. response within the U.S. archives.

My findings of Soviet caution have given legitimacy to the structural Marxist argument. Structural Marxism argues that the U.S. was not concerned about the Soviet threat in the less developed world. They contend that the U.S. was more concerned with the structural economic interests of U.S. capital. On the other hand, the data has also given credence, both in Buffer Zone and Asia, to the theory of domestic politics. These regions witnessed a divergence in policy emphasis and policy proposals by various U.S. agencies. Thus, I will continue to test these important theories throughout this chapter.

To better examine these theories, however, this chapter will now analyze the archives pertaining to the Western Alliance. These archives could provide additional clues as to how U.S. policymakers truly viewed the international strategic environment. After all, structural Marxists contend that the U.S. was significantly worried about its long-term credibility and power in the Western Bloc. The U.S. archives in the Western Alliance could help answer whether the structural Marxist view is correct or not.

Regional Analysis of U.S. Actions in the Third World during Détente

\section{Section Introduction}

Regional Analysis of U.S. Actions in Asia

The archival analysis of Asia during the final years of Détente highlights some significant U.S. moves in the region. Both the State Department and the Defense Department are shown to have pushed hard to strengthen U.S. interests and the U.S. balance of power in Asia. However, the archives reveal contrasting views on what exactly was the most important aspect of U.S. policy in the region. Records from the 
State Department and the Defense Department show each agency pursuing very distinct strategies on the behalf of the U.S. While the U.S. State Department's archives focus on strengthening Southeast Asia (through economic means mainly) as the core of U.S. strategy in Asia, the Defense Department's records focused its attention on improving U.S. naval power in the region.

However, as we witnessed in the last chapter, the initial archives of the Defense Department were not presented in the same optimistic light as those within the State Department. Defense Department archives revealed an agency that was extremely worried about recent Soviet naval enhancements and activities in Northeast Asia. More specifically, they were concerned with how such developments would affect Japanese security. Arguing that the new situation was "in clear contrast with the past position of U.S. military superiority...the Soviet Pacific fleet and naval aircraft can [now] credibly challenge the U.S. and its allies", the Defensive Department's archives during the latter years of Détente focused much more (compared with State) on improving the military readiness of the U.S. in the region ("US/Japan-USSR Balance”, p. 1). Nevertheless, Defense Department archives do acknowledge that the tide had turned in the U.S.' favor by the end of the 1970's.

\section{State Department}

A 1979 State Department declassified report, entitled "Southeast Asia", depicts ASEAN Bloc survival as the most important buffer to maintaining political stability (containing the Soviets) in the region. In fact, the State Department firmly believed that supporting ASEAN was the best counter against the further rise of Vietnam and the U.S.S.R. in the region ("Southeast Asia", p. 1-2). To achieve the strategy of countering 
the rise of Vietnam in Southeast Asia, the report focuses on helping the ASEAN Bloc rise up economically.

State Department strategy in the region was two-pronged. First, they helped coordinate the necessary military aid to ASEAN members, specifically those that were considered essential to maintaining the alliance. A 1975 report from the State Department, entitled "Issues Paper on Future Pacific Strategy", called for increased military aid for Indonesia. Considered an "influential member" of the ASEAN Bloc, U.S. policy called for "nurturing closer ties with this potential leader of Southeast Asia" (p. 4). The same policies were also promoted for Thailand. In an attempt to bolster Thailand's goal of strengthening its ties to ASEAN (in order to pursue a foreign policy independent from Vietnam), the report called for maintaining U.S. military assistance ("Issues Paper on Future Pacific Strategy”, p. 4).

However, the most significant strategy revolved around the significant political and economic support the U.S. placed upon the creation and development of the ASEAN Bloc. The State Department report explicitly states that only a "total collapse of will by the Asians themselves" would have led to additional Soviet gains in this region ("Issues Paper on Future Pacific Strategy", p. 6). Arguing that the basic threat faced by ASEAN leaders dealt not with external threats, but with internal subversion, the report states that the elimination of poverty and racial strife in the region would go a long way in preventing any major power from dominating the region ("Issues Paper on Future Pacific Strategy", pp. 5-6).

The State Department also argues that U.S. and Japanese objectives in Southeast Asia were parallel to each other. Thanks to, "frequent and candid exchanges on the 
situation in Indochina and the ASEAN region, we (the U.S. and Japan) have cooperated actively on such important issues as seeking to contain conflicts [and] minimize the Soviet presence" ("Southeast Asia", p. 1). This is exactly why Japan "greatly stepped up its economic assistance" as well was as trade and investment to the region" ("Southeast Asia”, p. 1). Integrating Japan's economy with the ASEAN Bloc was seen as something that enhanced the economic security of Japan and the political security of the Western Alliance in the region.

Moreover, the 1975 report, entitled "Issues Paper on Future Pacific Strategy", highlighted the fact that the rise of the ASEAN Bloc was helping to achieve new gains for the U.S. and its Japanese ally. Stating that "despite our disengagement from Indochina and the decline in our military profile in the area, the trend towards the expansion of our trade (and Japan's) and investment in East Asia and the economic integration (into the U.S.-led world system) of the Pacific Basin will continue", the report highlights a $30 \%$ increase in trade with the region as well as a $25 \%$ increase in U.S. exports to the region. Increasing Japanese trade and influence within ASEAN was considered significant in bolstering the Western Alliance. In fact, the U.S. placed pressure on Japan to play a larger economic and political role in East Asia ("Issues Paper on Future Pacific Strategy", p. 6).

After all, Japan's interests in the region were much more intense than that of the U.S. Dependent on raw materials for the continuation of its industrial economy, the Japanese moved quickly towards working with ASEAN members. However, rather than simply exploiting these countries (through extremely unfair trade agreements), as is typically done to other raw material producing nations by the developed world, Japan was 
convinced that "regional stability (deterring U.S.S.R.) would depend on [securing] the economic and political strength of the ASEAN countries" (Issues Paper on Future Pacific Strategy, p. 3).

All in all, the State Department argues that the U.S./West was stronger in the region than the Soviets and was taking the actions necessary to become even stronger. For instance, a report entitled "US and Japanese Relations with ASEAN", argues that "ASEAN Unity, while still limited, contrasts sharply with the disarray of the Communist nations" (p. 3). Overall, the State Department knew that the economic power of the U.S. and Japan and the West was giving them a distinct advantage to cultivate allies in this region.

\section{Defense Department}

The last chapter found the Defense Department stressing that the new international strategic (military naval balance of power) situation was "in clear contrast with the past position of U.S. military superiority.... [and that] the Soviet Pacific fleet and naval aircraft can [now] credibly challenge the U.S. and its allies" ("US/Japan-USSR Balance", p. 1). However, speaking to several important Japanese leaders, such as Prime Minister Ohira, Foreign Minister Sonoda, and Defense Minister Yamashita, Secretary of Defense Harold Brown emphasized in October of 1979 that there was a new strategic situation in regard to the naval balance of power. In fact, Brown reversed his previous pessimistic views on the naval balance of power and argues:

President Carter decided more than two years ago to reaffirm U.S. commitments in the Pacific and to maintain existing U.S. military capabilities in the area with the exception of planned adjustments in our force levels in Korea. We have honored that pledge....We have also provided tangible evidence of our 
commitment to the security of Japan and other Asian allies through qualitative improvements in our forces in the Pacific. ("Honorable Harold Brown", p. 19)

The Secretary of Defense was not the only one in the Defense Department to suggest that there was a shift in favor of the U.S. Improvements to U.S. conventional military power in the Pacific were already being cited by Secretary of the Navy James Woolsey by December of 1978. Meeting with Japanese Defense representative Minoru Tampa, James Woolsey pointed out that Congress had "turned the corner" by significantly upgrading defense spending during the latter part of the 1970's (“Conversation with Minoru Tampa on Military Relations", p. 2). The lull in spending that occurred between 1974 and 1975 was no longer in place. In fact, Woolsey added that shipbuilding, marine aircrafts, submarines, and land-based missiles for Asia were now moving ahead full throttle ("Conversation with Minoru Tampa on Military Relations”, p. 2).

\section{Key Policymakers Agree}

Comments by President Carter also suggest the U.S. was significantly gaining back ground during the late 1970's. In regard to the naval Pacific forces, President Carter pointed out during his meeting with the Japanese Prime Minister in May 24, 1978, that the U.S. was significantly improving its Pacific forces (F 14s, F15s, F16s, AWACs, the Trident, and naval power) ("Your Visit to Japan", p. 7). President Carter argued that continuing to develop ASEAN was vital for U.S. and Japanese interests in the region visà-vis the Soviet Union. As such, the President expressed to the Japanese Prime Minister Ohira that the U.S. would help improve the "economic and political strength of ASEAN" (“Summary of the President's Meeting with Japanese Prime Minister Ohira”, p. 2). 
Brzezinski, Carter's NSA Advisor, also agreed that U.S. economic policy in Asia was helping to turn Southeast Asia against the Soviet Bloc and argued that there was a strong determination on the part of the U.S. to isolate the Soviet Union in Asia. For this reason, Brzezinski commented to Japanese Foreign Minister Sunao Sonoda about the U.S.'s determination to promote a world order in which a "large number of regionally influential countries would assume more independent responsibility in promoting independence from the Soviet influence" ("Summary of Dr. Brzezinski's Meeting with Foreign Minister Sunao Sunoda”, p. 3). In furtherance of this strategy, Brzezinski cited the development of the ASEAN Bloc and the U.S./Japanese's effort to widen the SinoSoviet split as significant occurrences. Brzezinski praised "the creative role Japan had played in supporting the "security and prosperity of ASEAN countries" ("Summary of Dr. Brzezinski’s Meeting with Foreign Minister Sunao Sunoda", p. 4).

In regard to the military balance, Brzezinski believed that "we [the U.S. and Japan] have made significant advances in the promotion of our strategic objectives during the past year and a half" ("Dr. Brzezinski's Meeting with Foreign Minister Sunao Sunoda", p. 4). He dismissed the view that the Soviet Union was gaining on the U.S. He believed it was a "distortion and a reflection of only one dimension, that of military power. Even though the Soviets may have gained ground in the military realm, the U.S. was taking energetic steps to correct this" ("Dr. Brzezinski’s Meeting with Foreign Minister Sunao Sunoda", p. 4). Such steps included developing new weapons systems and improving the strategic balance. Improving the strategic balance, according to Brzezinski, revolved around the U.S. and its policies with China, "because our [the U.S.'s] relationship with it had broad global strategic consequences" ("Summary of Dr. 
Brzezinski's Meeting with Foreign Minister Sunao Sunoda", p. 4). He also conveyed to Sunoda that the U.S.-Japanese strategy (increasing ties with China) was helping improve the balance of power by shifting the Chinese away from the Soviet Bloc and towards the West.

\section{Section Conclusion}

The archival evidence outlined in the records of the State Department and the Defense Department/NSC suggests the U.S. was on the offensive in Southeast Asia during the late 1970's. Though differing in specific strategy, the evidence finds that both agencies pushed for the further development of policies that would promote either the economic or military power of the U.S. at the expense of the Soviet Bloc. In addition to evidence from U.S. agencies, I also found extensive evidence articulating the same view from President Carter and his very important National Security Advisor, Brzezinski. All of this conforms to my previous findings in chapters three and four. The quantitative and archival data in these chapters showed the West aggressive with its foreign aid to the ASEAN Bloc and the Soviets defensive in the region due to the Sino-Soviet split.

So what does all this suggest? For structural Marxists it suggests that the State Department and the Defense Department where focusing on different aspects of imperialism. The State Department was focusing on integrating the ASEAN Bloc nations into the Western capitalist system. In contrast, the Defense Department was upgrading its military capabilities in order to deter non-Western-Bloc from interfering with the accumulation of capital. Moreover, National Security Advisor Brzezinski stated above that calculations that suggested the Soviets had the advantage in the region were simply wrong as they only took the military balance of power into consideration. Economics 
mattered and economic policy was the reason for the U.S.'s wide advantage in the region. Brzezinski also noted to Japanese Foreign Minister Sunoda that:

U.S. policy towards China was not based on considerations of short-term tactical advantages vis-à-vis the Soviet Union....our point of departure over the long-term was a sustained long-term improvement of relations with China and modernization of that country in close cooperation with the West rather than with the Soviet Union.” (“Summary of Dr. Brzezinski’s Meeting with Foreign Minister Sunao Sunoda”, p. 5)

Brzezinski's statement ultimately speaks volumes, according to structural Marxists, in regard to how U.S. political and strategic power truly comes from its economic power. It is only after Brzezinski lays out the central role of promoting U.S. economic power that he tells the Japanese Foreign Minister "the U.S. was also concerned with Chinese security needs — vis-à-vis the Soviet Union, Vietnam, and Cambodia....[and the] continued Soviet presence, particularly naval presence in Southeast Asia" ("Summary of Dr. Brzezinski’s Meeting with Foreign Minister Sunao Sunoda”, p. 5).

Domestic politics, at first glance, seems to be a bit weaker as an international relations theory when it comes to explaining U.S. foreign policy in Asia. While the State Department and the Defense Department pursued different paths, large-scale inter-agency conflict seems to be vacant during the late 1970's when it comes to Southeast Asia. After all, both agencies argued the balance of power advantage was on the U.S's side during the late 1970's.

Adherents of domestic politics, however, would suggest that such an outcome, unlike later on in Afghanistan, is due to an unintended congruence of their overall policy missions in this area of the world. That is, the Defense Department's primary mission (NSC as well) of weakening the Soviet Bloc through the use of the "China card" came 
together with the State Department's primary mission of promoting stability and economic growth in the region. After all, the last chapter did see the State Department and Defense Department have different points of views in regard to whether the Soviets were initially acting aggressive in this region. The State Department did not believe so while the Defense Department did. Thus, the seeds of conflict were already there and they were only masked by the success of U.S. policy in the region.

While structural Marxists and adherents to bureaucratic politics may vouch for their respective theories, this is not the case with balance of threat realists. The evidence firmly dismisses their arguments. U.S. aggression with a cautious Soviet Bloc at hand points against the theoretical tenets of balance of threat realism.

\section{Regional Analysis of U.S. Actions in Middle East}

\section{Section Introduction}

The archival record suggests that the U.S. was on the offensive in the Middle East during the 1970's. Kissinger, the architect of presidents Nixon's and Ford's policies in the Middle East at this time, confirms that the U.S. sought to expand its influence in the Middle East throughout the 1970's. The former Secretary of State argued that "our [overall] strategy [during the 1970's] was to reduce the Soviet role in the Middle East because our respective interests in the area could not be reconciled" (Slater, 1990, p. 574). One of the ways in which to do that, as the archives will confirm, was to use the Arab-Israeli October War peace negotiations in such a manner as to marginalize the Soviets in the Middle East. Exercising such a strategy, in the face of a cautious Soviet Union (as shown by the quantitative data in chapter three and the archives in chapter four), suggests U.S. policymakers were determined to weaken the Soviets during Détente. 
Indeed, U.S. leaders then went ahead and helped re-orient the political orientation of Egypt (using the leverage of the Sinai Peninsula) away from Moscow and towards the West. Such were the fruits of the Arab-Israeli conflict for the U.S. None of this should be surprising. As my analysis showed in chapter three, the U.S. was already starting to pump in significantly more military and economic assistance to the Egypt during the early 1970’s.

\section{Soviet Actions}

To begin with, records from the National Security Archive (NSA) show (as did the last chapter) that the U.S.S.R. was not an aggressive superpower in the Middle East during the 1970's. It was Egypt and Syria that made the ultimate decision to launch the 1973 October War (they were frustrated with the lack of assistance from the Soviets). The Soviet Union was not involved and did not push their proxies. In fact, NSA document \#13 of the 1973 October War demonstrates that the U.S.S.R.'s failure to support Egypt and Syria's drive for war had led to "a major crisis in Arab-Israeli relations" ("The October War and U.S. Strategy", p. 2). The Soviets did not believe their Arab allies could defeat the mighty Israeli military. NSA document \#63 also confirms this to be the case. Henry Kissinger argues in this memo that the Soviets did not believe the Arabs countries could win ("The October War and U.S. Strategy", p. 9). Even when the war began, Kissinger states that Soviet actions in the 1973 October War were "not as provocative as those in 1967" (The October War and U.S. Strategy, document \# 63, p. $10)$. 


\section{Kissinger and U.S. Actions}

Soviet actions are in far contrast to the actions of the U.S. Rather than work with the cautious Soviet Union in an attempt to cease hostilities, Kissinger's actions shows the U.S. encouraging the aggressive actions of its Israeli proxy. For starters, rather than an honest push for a cease-fire in the United Nations to the 1973 Arab-Israeli conflict, NSA document \#18 chronicles Kissinger's attempt to allow the Israeli military the ability to strike back against the gains of Egypt and Syria. Kissinger, speaking with Israeli officials, argued in favor of the Israeli Defense Forces moving "as fast as possible" while the U.S. convinces the British to delay UN cease-fire actions ("The October War and U.S. Strategy", p. 4).

Even when the cease-fire was finally agreed to, NSA documents show Kissinger giving the go ahead for Israeli violations of the UN cease-fire. NSA documents \#51 and \#54 confirm this to be the case. Document \#51 witnesses Kissinger stating to Israeli officials that the U.S. "would understand if Israelis felt they required some additional time for military dispositions before cease-fire takes effect. We want to shoot for 12 hours between Security Council decision and cease-fire but could accept the Israeli's taking slightly longer” (“The October War and U.S. Strategy”, p. 4). Document \#54 continues down the same path as Kissinger tells Israeli Prime Minister Golda Meier that there would be "no violent protests from Washington" should something happen "during the night while I'm flying (to help sign the cease-fire)" ("The October War and U.S. Strategy", p. 4).

Ultimately, this was simply an invitation by Kissinger to the Israelis that they could go ahead and improve their bargaining situation. Surely enough, the Israeli military 
did take advantage of the situation and improved their military positioning before the cease-fire finally took effect. In fact, NSA document \#67 comments that "Israeli violations of the October 23/24 cease-fire appear to have reflected an effort to isolate the Egyptians' southern flank" (“The October War and U.S. Strategy”, p. 1). It also argues that "the Arab world will soon realize that there will be no automatic Israeli withdrawal, and that Sadat's and Asad's glorious assertions of Arab dignity suddenly turned into another crushing defeat" (“The October War and U.S. Strategy", document \# 67, p. 2).

The Soviets bitterly complained about this strategy. NSA document \#65, a letter from Soviet Premier Leonard Brezhnev to Secretary of State Kissinger, argues that the U.S. must put an "end to such provocateur behavior of Tel Aviv" ("The October War and U.S. Strategy", p. 3). The document chronicles an extensive list of Israeli violations of the cease-fire. However, the U.S. and the Israelis simply refused to negotiate until Israel was able to reverse Arab gains. This is archived in document $\# 13$ of the 1973 October War. Highlighting a classified meeting between Chinese officials, such as Ambassador Huan Chen, and U.S. officials, such as Kissinger and members of the National Security Council, this memo finds Kissinger directly stating to the Chinese that "we advocate a return to the status quo (post-1967 borders) ante before the fighting started" ("The October War and U.S. Strategy", document \#13, p. 3). The U.S.'s strategy was to provide as much leverage for the Israelis as possible. The U.S. would simply not tolerate Egypt's and Syria's (as entrenched Soviet allies) drive to capture their lost territories from the 1967 war (without a joint Israeli peace agreement). There was no middle ground. Either the Arabs returned to the post-1967 borders or the war continued. 
Kissinger really never took negotiations with the Soviet Union that seriously. In regard to the original cease-fire negotiations between the Arabs and the Israelis, Kissinger states (in document \#63) that it became apparent that "the Soviets could not deliver to what was in effect a cease-fire in place" ("The October War and U.S. Strategy", p. 9). In other words, the Soviets could not force their proxies to return to the post-1967 borders. Thus, Kissinger argues that "we (the U.S.) had no choice except to go another route...And that therefore the longer the war would go on, the more likely would be a situation in which they (Arab states) would have to ask for a cease-fire rather than we. And this is the reason why we started the airlift on October 13 (to ensure a quick and decisive Israeli victory)" (“The October War and U.S. Strategy”, document \#63, p. 10). In short, Kissinger recognized the superior might of the Israeli military and thus he made sure that the U.S. aided the Israelis. For instance, document \#18 shows Kissinger approving many different types of weapons for the Israelis in the early stages of the conflict ("The October War and U.S. Strategy", p. 4).

Nevertheless, Kissinger's strategy went beyond trying to compensate for the U.S.S.R.'s lack of control over its Arab allies. Kissinger wanted to weaken the Soviet Union in the Middle East. Documented in archive \# 17, just a couple days after the start of the conflict (October 6, 1973), I find Kissinger stating to members of the Chinese government that "our strategic objective is to prevent the Soviets from getting a dominant position in the Middle East" ("The October War and U.S. Strategy", p. 2). The best way to achieve this was to weaken their alliances. This is why Kissinger stated one of the U.S.'s objectives was to show “that whoever gets help from the Soviet Union cannot 
achieve his [their] objective[s], whatever it is" ("The October War and U.S. Strategy", document \#17, p. 2).

Ultimately, Kissinger's actions during the October War in favor of Israel were the realization of this strategy. The U.S. was letting strategic countries in the Middle East, such as Egypt, know that the only way in which they would achieve part of their demands, regardless of how legitimate they were, was to work with the U.S. Allying themselves with the U.S.S.R. or seeking grievances through the battlefield would not be tolerated.

Indeed, once the U.S. and Israel had militarily defeated Egypt and Syria, and diplomacy resumed, Kissinger worked behind the scenes to cut off the U.S.S.R. from negotiations, which was a direct violation of the 1972 summit conference agreement between Moscow and Washington (Slater, 1990, p. 575). Kissinger actually used Détente as a way to would weaken the Soviet Bloc. For instance, he states to his staff on October 23, 1973 that, "there was enough in that relationship (Détente) to moderate them (the Soviets) at critical points" ("The October War and U.S. Strategy", document \#13, p. 1). Taken as a whole, the result of the 1973 October War for the Soviets, according to Henry Kissinger, "is that for the third time since 1953 they [Soviet Union] have lost much of the equipment they put into the Arab world. They were once again defeated" ("The October War and U.S. Strategy", document \# 63, p. 16).

Using U.S. political and military leverage during the 1973 October war and cutting off the U.S.S.R. from negotiations in the Middle East ultimately resulted in Egypt's shift from the Soviet orbit unto the West's. Kissinger's early 1970's strategy ultimately prevailed. The Soviets began to lose allies and they lost their most significant 
ally in the region. They witnessed "Egypt's shift away from the Soviet Bloc, Arab socialism and warfare and toward the United States, economic opening, and peace" (Alterman, 2005, p. 360). Egypt's loss was helped along by the economic incentives provided by the U.S. and its strategic allies in the region. Jon Alterman, writing for the Center for Strategic and International Studies, explains that Egyptian President Anwar Sadat's "turn away from republican revolutionary rhetoric....bought him more than $\$ 5$ billion in bilateral economic aid from the oil-rich sheikdoms of the Persian Gulf (U.S. allies) between 1973 and1976. His reorientation toward the U.S. in the 1970's won him tens of billions more dollars from the U.S.” (2005, p. 360).

\section{U.S. Agency Cooperation}

Tightening the relationship with Egypt was pushed through with the assistance of all significant U.S. intelligence agencies. All of the top tier U.S. agencies (State, Defense, and CIA), with the leadership of the National Security Council, oversaw the U.S. Sinai Support Mission. The goal of the U.S. Sinai Support mission was to help coordinate Israel's peaceful disengagement from the Sinai Peninsula starting in early 1976 ("Establishment of U.S. Sinai Support Mission", p. 1). None of these agencies complained that shifting Egypt's alliance could damage the U.S.'s relationship with the Soviets.

The State Department helped coordinate an enormous amount of economic assistance for Egypt starting in early 1976. A declassified secret memorandum from the Kissinger transcripts, entitled "Meeting with State Department Advisors", finds Kissinger and many of the top-tier of the State Department pressing for billions to be sent while also trying to figure out other ways in which to help Egypt ("Meeting with State 
Department Advisors", p. 3). In fact, Kissinger and the rest of the State Department staff were fretting about significant problems in the Egyptian economy and how this was "eroding Sadat's position" in the country ("Meeting with State Department Advisors", p. 4). With a new significant ally in the Middle East, Kissinger and the rest of the State Department wanted to make sure there were no setbacks in this region.

It was also apparent that the Defense Intelligence (DI) Community also supported the U.S.'s push to envelope Egypt as a U.S. ally. More than that, the DI Community actually encouraged the deployment of Egypt in support of other U.S. allies in the Middle East. The Shah of Iran is one such example. A declassified DI document, entitled "Egypt: Efforts to Support the Shah of Iran", from November of 1978 is just one case in point of the U.S. intelligence community's push to strengthen U.S. power in the region (Egypt, p. $1)$.

\section{Section Conclusion}

The West and Israel ultimately proved too mighty for the Soviets to deal with. The Soviets' faithfulness to Détente in this region of the world, which Kissinger himself admitted, and the fact the U.S. possessed a significant amount of bargaining capital in the settlement situation, due to the might of Israel, proved fatal to any Soviet aspirations in the region. It was simply dammed if you do and dammed if you don't. Had the Soviets provided significant assistance to Egypt and Syria it could have launched a massive military confrontation in this region. Though they could battle it out within the nuclear realm, the Soviets knew their involvement would not have swayed a conventional war in their favor in this region. However, by not sending offensive weapons to the Arabs they alienated their allies to the breaking point. Egypt and Syria moved to capture their lost 
territories. Ultimately, with the work of Kissinger, the U.S. was able to use economic and territorial carrots to shift the allegiance of Egypt toward the West. Thus, it is obvious the Soviets were cautious while U.S. policymakers exploited their advantages.

These findings parallel nicely with those of chapters three and four. As shown in those chapters, the Soviets acted cautiously (according to the quantitative and archival evidence. The Soviets did not send offensive weapons to Egypt while the U.S./West pushed forward in this region with the help of Israel.

These findings also continue the onslaught against balance of threat realism. The archival evidence firmly points in the direction of U.S. aggression. We also discovered that the U.S. was intensely worried about the collapse of the Western Alliance. This, of course, fits nicely with structural Marxism. While not as strong, domestic politics cannot be completely dismissed. Something can certainly be said for Kissinger's powerful lobbying ability within the Nixon administration.

Regional Analysis of U.S. Actions in Southern Africa

\section{Section Introduction}

The archives from the last chapter, pertaining to Soviet actions, were quite mixed. I first discovered that the NSC and the CIA argued the Soviets were cautious. However, this shifted once the Soviets achieved victory. To better understand whether this was an initial mistake by the NSC and CIA or just a shift in policy, I will now analyze the U.S. archives pertaining to U.S. actions in Southern Africa.

Archival research, such as U.S. State Department and Cuban archives, on Southern Africa does, in fact, seem to conflict with the latter assertion made by the State Department and the NSC about Soviets being aggressive in 1975 in the Angola conflict. 
Rather than finding the Soviet bear and its Cuban proxy pushed for war, the archives suggest the U.S./West was aggressive in this region. The evidence also suggests that it was the U.S. that made the aggressive decision in the opening saga of this conflict. In fact, it is the U.S. who first began to coordinate and send foreign troops into Angola. These policies were firmly chastised by many members of the U.S. State Department. Officials in these agencies did not believe such actions were in U.S. interests. However, they were systematically silenced by officials in the NSC and the CIA. State Department officials, as well as State Department and Defense Department archives, suggest U.S. actions were premised on promoting U.S. economic interests.

State Department Fights for Diplomacy

The U.S. actions and decisions, especially those that occurred in July of 1975 were covert and aggressive according to many members of the State Department. Assistant Secretary Davis, writing for the State Department's bureau of African affairs argued (supported by much of the research from his State Department colleagues) that the U.S. should stay out of the Angolan conflict and seek a diplomatic solution. He chronicles how a U.S. interagency tasks force "composed of high U.S. experts on Africa strongly opposed military intervention; instead ... they called for diplomatic efforts to encourage a political settlement among the three factions to avert bloodshed" (Davis, 1978, Section II, para. 10). These efforts included putting pressure on the new center-left government of Portugal, influential African governments, and working with the UN (Davis, 1978, Section II, para. 11).

All in all, Davis (1978) firmly believed that bellicose actions on the part of the U.S. would only strengthen the appeal of the Soviet Bloc to the MPLA. His push, and the 
push provided by other military experts, on June $23^{\text {rd }}, 1975$ was to no avail for the moment. He describes in his personal memoirs how "at the direction of National Security Council aides, the task force recommendation [on a more diplomatic approach] was removed from the report and presented to NSC members as merely one policy option" (Davis, 1978, Section II, para. 10).

Assistant Secretary Davis and many within the State Department would continue to butt heads with the NSC as well as the CIA (specifically Secretary of State Kissinger) for several more months. Writing in his personal memoir, he blasts many of the assertions presented by a subsequent CIA Action Plan paper to the NSC and the Ford Administration. For example, he contests that:

The [CIA] Paper suggests that arming Roberto and Savimbi could "discourage the further resort to arms and civil war. So far, however, the arming of the various factions has fed the civil war, not discouraged it. The Paper gives no clear explanation where the courses of action described will take us, explicitly acknowledging that the anti-Neto forces cannot win militarily, and rather hopefully expressing the view that restoration of some sort of triangular 'balance' (which has been the past reality) will produce a peaceful, negotiated, collective solution (which the record in Angola and experience elsewhere in Africa indicate is most unlikely)." (Davis, 1978, Section: "Other Questions, para. 1)

Thus, Davis is questioning what the exact goals of the NSC and the CIA were.

Perhaps the following comments by Davis help shed some light in this. These comments, which also attack the NSC-CIA covert action plan in a July $12^{\text {th }}, 1975$ memo to the State Department representative on the NSC Committee (Under Secretary Joseph J. Sisco), imply that economic motives may be overriding the strategic interests of the U.S. He writes:

covert intervention would not serve larger U.S. interests; that an attempted intervention could not be kept secret; and that a covert intervention would have to 
be so circumscribed as to fall between stools in any case - while the other side could escalate at will....? We have so far succeeded in avoiding the engagement of our vital interest in Angola and even the accusations of U.S. intervention are sporadic and not a serious political liability. So far as concrete interests are concerned, Gulfs $\$ 300$ million stake in Cabinda is the principal one. . . If we become engaged under ... [the specific proposals put forward for covert military intervention] (and developments over this weekend make it clear - if it was not clear before - that ... [the proposals under consideration] would probably be inadequate), the Soviets will become aware of our decision almost immediately. The CIA paper significantly notes that the 'Soviets enjoy greater freedom of action in the covert supply of arm, equipment and ammunition' and 'can escalate the level of their aid more readily than we.' The CIA paper makes clear that in the best of circumstances we won't be able to win. If we are to have a test of strength with the Soviets, we should find a more advantageous place. (Davis, 1978, Section: III, para. 2-5).

In the end, Davis (1978) believed that diplomacy "was favored by most of the agencies participating" (Section: "Other Questions", para. 4). However, "the CIA Action Plan was considered once again by the Forty Committee (I believe on July 17); it was given to President Ford sometime within the next several days; and it was approved" (Davis, 1978, Section: "Other Questions”, para. 15). The hawks defeated the doves. Aggression trumped diplomacy.

\section{Kissinger's Power and U.S. Instigation}

Ultimately, Secretary of State Kissinger simply possessed too much power and too much influence over the U.S. President. According to Robert Hultslander, who served as CIA station chief in Angola, "Kissinger's support for the anti-communist faction in Angola's civil war during the mid-1970s was a major contributor to instability in Southern Africa at that time" (Gedda, para. 1). Hultslander further contends (his comments can be found in the National Security Archives) that Kissinger was determined to challenge the Soviet Union, although no vital U.S. interests were at stake" (Gedda, 
para. 8). All things considered, it was not Soviet assistance to the MPLA, as Kissinger suggested, that contributed to the MPLA victory in Angola but U.S. policy. Hultslander states that "it was our [U.S.] policies which caused the destabilization" (Gedda, para. 4). The positions of the State Department were ultimately "irrelevant.... U.S. policy towards Angola would be determined not by what happened there, but by his [Kissinger's] conception of the U.S. position in the world at the time" ("Kissinger Watch", p. 6).

This is why Nathaniel Davis agrees with research that shows the U.S. was extremely involved in the opening drama of the Angolan conflict. In fact, records indicate that U.S. support for the FNLA and UNITA actually began in January of 1975 when the CIA requested over $\$ 300,000$ in covert aid for the FNLA. Anticipating the collapse of the Portuguese colony, CIA officials argued that such aid would provide the U.S. "with some capital in the bank with one of the leaders of a government that was going to control a fairly sizable country" (Harder, para. 13). This is corroborated by Davis in July of 1975. He states that:

William G. Hyland, the Director of the State Department's Bureau of Intelligence and Research, told me that a $\$ 300,000$ program of covert support for the veteran Angolan liberation fighter, Holden Roberto, had been approved that past January by the Forty Committee, the top-level review board that passes on covert operations abroad. This came as a surprise. While the money was for political action and expenses, and not for arms, I had not been aware that such programs were still being approved in the wake of the congressional investigations and interest in U.S. covert activities abroad. (Section: II, para. 1)

On the other hand, Soviet military aid towards the MPLA also started in March of 1975 ("Kissinger Watch", p. 7). This was obviously several months after the CIA became involved. Indeed, Assistant Secretary of State Newsom told British officials that "we [the United States] were surprised by the low level [during early 1975] of Soviet support to 
the liberation movements in the Portuguese territories" ("Kissinger Watch", p. 7). Of course, Kissinger would dismiss his views as well.

\section{Cuban Archives show U.S. Aggression}

Peter Gleijeses (2003), author of Conflicting Missions: Secret Cuban Documents on the History of Africa Involvement, also finds startling evidence suggesting that the United States (and its allies), not Cuba/Soviet Union, was the principal instigator of the actual war itself. Using Cuban and American archives, Gleijeses (2003) shows that it was the U.S., with the help of South Africa and China, who began to coordinate the inflow of foreign into Angola in July of 1975, thereby starting the conflict (p. 3).

Gleijeses (2003) also catches Secretary of State Kissinger in a serious of lies regarding U.S. motives. According to Gleijeses (2003):

One lie is that Washington intervened in Angola in 1975 only after large numbers of Cuban troops had been sent to that country to support the MPLA. Kissinger testified before Congress in January 76 that 'in August (1975) intelligence reports indicated the presence of Soviet and Cuban military advisers, trainers and troops, including the first Cuban combat troops. (p. 146).

However, this was in flat contradiction to the now declassified CIA and other intelligence reports of the time. Kissinger was simply "rewriting the history." Gleijeses (2003) goes on and argues that, "when the United States decided to launch the covert intervention, in June and July, not only were there no Cubans in Angola, but the U.S. government and the CIA were not even thinking about any Cuban presence in Angola" (p. 146). He states that "if you look at the CIA reports which were done at the time, the Cubans were totally out of the picture" (Gleijeses, 2003, p. 147). Thus, Gleijeses (2003) concludes that "Kissinger forced the CIA to rewrite a document on Angola to show an earlier Cuban presence than was accurate" (p. 147). 
Thus, Gleijeses' (2003) research shows that Cuban troop intervention was actually a response to U.S./South African joint covert operations from Zaire (p. 3). President Castro dispatched troops into the country only after he determined that the Angolans were under attack. More than that, Castro did not even wait for the Soviets go ahead. Gleijeses (2003) documents that Cuban leaders immediately sent troops to push back the South Africans and they did this without directives from Moscow. Indeed, Soviet officials were stunned by Cuban actions (p. 4).

State Department Officials Agree with Cuban Archives

Recent interviews with U.S. government officials confirm the validity and insightful interpretation of Gleijeses' findings. For instance, Thomas Hughes, a former director of intelligence for the State Department during the Angola conflict comments that this "book does seem to have nailed Henry [Kissinger] quite specifically on this question... [and] it is an impressive account, a sad story that seems to be written almost out of a feeling that it might be lost" (French, Section: "Devastating Warfare", para 6.). Davis also supports this work and argues that "considering that things came to a head over covert action in the U.S. government in mid-July, there is no reason to believe we were responding to Cuban involvement in Angola" (French, Section: "Devastating Warfare", para 5). After all, the Cubans were not yet physically present in the conflict nor were they sending large amounts of assistance. Thus, the U.S. was fueling the conflict and sending in troops without any actual evidence that Cuban or Soviet troops were significantly involved in the conflict. 


\section{Economic Interests?}

Why did the NSC and the CIA work in favor of an aggressive approach? The answer lies in studying the fact that the superpower with the most economic interests on the line in Southern Africa was none other than the United States. An NSC report entitled "United States Policy toward Angola" piggybacks on the aforementioned assumptions made by Davis regarding the fact that U.S. actions in Angola revolved around economic and not strategic motives. For instance, the report argues that the U.S. must protect "U.S. investments, [the promotion of U.S. exports, and [the continuation of U.S. access] to Angola's raw materials" (“United States Policy Toward Angola”, p. 62). Such investments, which totaled $\$ 400$ million, included $\$ 300$ million worth of investments in the Gulf Oil Fields of Cabinda ("United States Policy Toward Angola", p. 62). Protecting U.S. investments in oil meant protecting such American companies as Texaco, Sun Oil, Hess, Amoco, and Conoco. These companies possessed significant oil holdings in Angola and they were worried that their previous oil concessions off the Angolan coast would not be honored by the MPLA.

Archives from the Defense Department also demonstrate the primacy of strategic economic resources in regards to U.S. interests in Angola. In a National Security Meeting on June 27, 1975 involving Secretary of State Kissinger, the President, CIA Director William Colby, and other high-level government officials, I find Secretary of Defense James Schlesinger stating that "we might wish to encourage the disintegration of Angola. Cabinda in the clutches of Mobutu (the U.S.'s Zairian ally) would mean far greater security of the petroleum resources" ("Meeting of the National Security Council”, p. 7). 
If the economic interest evidence does not suggest that the U.S. policy was based on economic resources, than I do not know what does.

The report also documents that U.S. exports and imports from Angola had significantly increased in the last few years. Increasing exports and imports had to continue (U.S. officials argued) since it was benefiting some of the most competitive U.S. business sectors. The economic interests section of the NSC report also highlights the importance of protecting U.S. mineral interests in the region of such U.S. companies as Guggenheim (diamonds), Chromalloy (gold), and Tenneco (sulphur) ("United States Policy Toward Angola”, p. 62).

Of course, Southern Africa was also important for the U.S. strategically. The transportation routes along Angola Western oil tankers and the overfly routes for U.S. military personnel could fall into grave risk should the Soviet-backed MPLA gain power in the region. The NSC and the State Department did worry that Soviet access to ports would increase the U.S.S.R.'s military capabilities in the region. However, there is not a lot of evidence in U.S. archives that the U.S. was overly concerned about these issues. The archives focus time and time again on the economic resources that Angola possessed. Section Conclusion

Overall, when I combine the U.S./South African covert actions, discovered in this chapter, with the lack of Soviet response, discovered in the previous chapter, it is obvious the U.S. was initially more aggressive in its actions than the U.S.S.R. Secretary of State Kissinger, with the help of the NSC and CIA, was simply determined to send covert U.S. aid towards U.S. allies from the very beginning. The State Department questioned these tactics. It did not believe that aggressive U.S. actions would work. Assistant Secretary 
Davis and the State Department machinery believed there were other ways to avoid war and avoid Soviet expansionism in the region. More specifically, Davis did not believe significant U.S. strategic interests were at play. However, Davis and the State Department were silenced by its more powerful foes.

These findings and the fact that U.S. government reports focused much more on the economic aspects of Angola (rather than the strategic aspects), means that balance of threat realism does not explain what occurred in Angola. Such archival evidence does suggest that structural Marxism can be regarded as possible explanatory theory. Cuba's determinative actions in this region, in light of Soviet caution, could suggest that the battle in Angola was primarily a battle between Cuba and the U.S. Peter Gleijeses believes this to be the case. He believes, from President Castro's very own statements to Kissinger's lies, that Angola was a North-South conflict (2003, p. 6). Weight is also added to this theory once you consider that Europe also provided significant assistance towards the FNLA. Officials in the Ford administration admitted that "French assistance was 'substantial' although below the American level, whereas they characterized British support as 'modest'” (Gleijeses, 2003, p. 137).

Domestic politics has a story to tell, however. As I showed, there was significant bureaucratic infighting. The State Department did not believe aggressive covert actions would lead to an outcome that suited U.S. interests in the region. Kissinger simply overrode the other intelligence agencies. Thus, adherents of domestic politics suggest U.S. policymakers, such as Kissinger, were out to support the interests of business interest groups in the U.S. However, they were defeated by other more hawkish U.S. agencies. 


\section{Section Introduction}

\section{Regional Analysis of U.S. Actions in Latin America}

The U.S. archives in the last chapter argued that the Soviet Union was not aggressive in Latin America during the 1970's. Despite large amount of Soviet assistance towards Cuba, as shown in chapter three, U.S. agency archives contested that the Soviets were not significantly involved in the region. Instead, U.S. archives argued that revolutionary turmoil in Latin America was the result of the political and economic repression pushed by U.S. clients in the region. As a result, U.S. agencies recommended that the U.S. use its political and economic power to change such behavior. This was the best way, in the eyes of many U.S. agencies, to curtail Soviet interventionism in Latin America. President Carter agreed with such an analysis. He embarked (publicly) on a quest to alter U.S. policies in the region.

Now I show that the Carter administration/U.S. agencies were not successfully able to push their clients in Latin America to adopt alternative policies that would have brought many leftist followers into the democratic fold and stopped the emerging revolutionary violence. Carter's liberal foreign policy towards Central America seems largely rhetorical. It was all purely political marketing meant to dissociate the U.S. from its clients in the region. Statistical evidence confirms this to be the case.

\section{Liberalism Defeats Realism?}

Robert Pastor, Carter's head national security advisor for Latin America, makes the case that the Carter administration attempted to pursue a more liberal and human foreign policy in Latin America. He writes about a battle that occurred on March 24, 1977 between several career officers of the State Department's American Republic 
Affairs (ARA) and the Defense Department against Secretary of State Vance, NSC Advisor Brzezinski, and the Treasury Department (Pastor, 1992, p. 25). The ARA and Defense argued in favor of a "special relationship" with Latin America consisting of helping countries that were the most strategic to the U.S. while Vance and Brzezinski argued in favor of a North-South strategy of pursuing liberalism throughout the region. Pastor chronicles that the doves won out over the hawks and attempted to deploy their favored approach (Pastor, 1992, p. 25).

\section{Failure to Change U.S. Policy}

However, there is damming evidence comes from Carter's national security advisor for Latin America. Robert Pastor (1992) concurs that [foreign aid] cuts towards Central American nations violating human rights "were not large, but symbolically the initiative was important" as it freed the U.S. from the policies of the past (p. 25). Pastor (1992) argues that Carter pursued such a policy believing that it would "send a clear signal that the U.S. was prepared to pay a price for pursuing human rights" (p. 25). However, the U.S. was really not ready to pay a price.

Subsequent U.S. actions demonstrate that the U.S. was extremely risk averse in regards to changing U.S. policy in this region. For instance, archival evidence undermines much of Carter's early 1977 human rights rhetoric (profoundly encompassed within Carter's January 1977 inaugural address). One of the most important documents pertaining to U.S. policy towards U.S.-allied repressive regimes, entitled "Presidential Review Memorandum NSC-28: Human Rights" failed to support many of the public statements made by President Carter in regards to how the U.S. should change course and pursue human rights and socioeconomic development in Latin America. Rather than 
pushing for change in the region, the report postulates a set of positives and negatives that tilts the picture heavily in favor of the negative drawbacks to promoting human rights ("NSC 28", p. 4). The negative possibilities, which include damaging U.S. national security interests, political and economic interests and retaliation by the recipient country of U.S. assistance against resources that U.S. vitally needs is pitted against supporting human rights for the sake of promoting human rights ("NSC 28", p. 5). The report also adds that the curtailment of U.S. economic and military aid towards repressive regimes "ought not to be considered lightly or until less drastic measures have been taken" ("NSC 28 ”, p. 15). These less drastic measures included public statements and various symbolic acts, which were simply useless.

\section{U.S. Clients Resist Change}

Consequently, it proved to be very difficult for President Carter and U.S. agencies to challenge U.S. clients in Latin America even when they actually wished to do it. The U.S. ran into a complete wall in regard to the cutting of military sales to repressive rightwing regimes in Latin America. Threats of aid cuts did not change the behavior of these regimes. For example, upon learning that the Carter Administration was going to cut military sales to Brazil in late 1977, Brazilian military leaders proclaimed that they would not accept $\$ 50$ million in military sales from the U.S. (Fagen, Section IV, para. 3). The political/military leaders of other Latin American right-wing regimes, such as Argentina, El Salvador, and Guatemala, announced similar intentions. They vowed to obtain military aid from alternative sources and blasted the U.S. for interference in Latin America “sovereign" affairs. 
The U.S. archives also show the Carter administration struggling to "convince" U.S. allies in Central America to change course. "U.S. Objectives and Goals in Guatemala", a December 1978 State Department report, pointed out that the government of Guatemala "while supporting U.S. initiatives aimed at improving the lot of the poorest Guatemalans, [their] efforts to remedy income inequities remain a low priority" ("U.S. Objectives and Goals in Guatemala", p. 3). The report chronicles that while the U.S. continued to push for a more humane approach in the region the Guatemalan government still "lacked sympathy" for the U.S. human rights approach.

In fact, the Carter administration's efforts to "hold-up" military aid from repressive regimes as an attempt to change their human rights and socioeconomic policies simply fell on deaf ears. Having helped establish and consolidate these repressive regimes over a period of several decades, it was simply too difficult for the U.S. to change or mold the behavior of its allies by simply cutting off U.S. military aid.

\section{Carter's Failure to Rein in U.S. Repressive Clients}

Regardless of this, all of the statistical evidence shows that the U.S. did not truly alter their foreign aid policies towards Latin America. For instance, a statistical study by Michael Stohl, David Carleton, and Steven Johnson (1984) entitled "Human Rights and U.S. Foreign Assistance" further backs up the archival evidence. This study finds that "the Carter administration did not implement a policy of human rights which actually guided the allocation of economic and military assistance" (Stohl et al, 1984, p. 215). The Carter administration simply allocated military and economic aid (for the most part) regardless of human rights. President Carter was only different in that he actually did not increase economic aid to countries that increased their human rights violations. In fact, 
President Carter did not significantly cut foreign assistance to strategic allies in Latin America (specifically Central America) that actually misbehaved. The study also found this to be true for the Nixon and Ford presidencies (Stohl et al, 1984, p. 221). These facts show that the U.S. simply continued (and this was the true strategy behind the Carter March 24, 1977 speech) talking the liberal economic talk.

James Lebovic (1988), in National Interests and U.S. Foreign Aid, further postulates that the Carter and the subsequent Reagan Administration also differed very little. His data suggests that "a great portion of Reagan policy can be explained by that of Carter, and even though aid amounts and recipients changed, some of the same interests (economic) prevailed in both" (Lebovic, p. 129). The only difference between Carter and Reagan was that Carter cut aid to human rights violators that were not aligned with the U.S. Such is of little significance however.

\section{Success in Panama}

However, there was one victory for the liberals in Panama. In fact, Pastor (1992) argues in The Carter Administration and Latin America: A Test of Principle that the

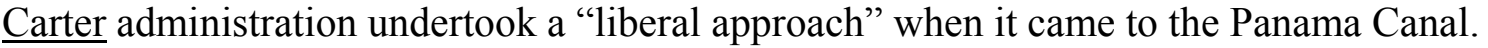
He argues that the Carter administration undertook significant political risk and endured significant criticisms from defense intelligence agencies when it came to the issue of handing over the Panama Canal to the Panamanians (1992, p. 52). Ultimately, this gesture was grand and it did fall in line with the liberal approach of undercutting revolutionary extremism by handing over more democracy and respect towards the Latin Americans. 


\section{Section Conclusion}

Overall, admissions from Carter's own Latin America national security advisor, the archival evidence, and statistical examinations of U.S. foreign aid to Latin America demonstrate that the Carter administration did not significantly pursue a "new policy" of liberalism in Central America. These facts, combined with the fact that U.S. archives show the Soviets as cautious in this region, significantly injures balance of threat realism. Carter's failure had significant consequences for U.S. policy in Central America. The result was significant revolutionary turmoil in Central America during the 1970's.

Why did President Carter not truly pursue liberalism in Latin America? Some scholars have suggested that domestic politics explains U.S. policy in Latin America, especially Central America, during the final years of the 1970's. It is suggested that these core U.S. interest groups fought against the liberal policies of President Carter and forced him to reverse course. After all, followers of domestic politics would argue that the doves chronicled by Robert Pastor were just beginning to lay the groundwork for a more human policy in the region. Handing over the Panama Canal is one example. However, they simply had very little time and they were defeated by more powerful elements.

Structural Marxists, however, would point out that it is only when conflict in Central America had all but exploded into significant revolutionary upheaval, that there was significant business conflict between labor-intensive and capital-intensive firms. Such business conflict at the end of Détente is very well documented by Ronald Cox (1994) in Power and Profits: U.S. Policy in Central America. However, such bureaucratic conflict did not significantly occur (for the most part) prior to Détente's collapse or the Nicaraguan revolution. It started in late 1979. The battle between the doves and hawks, 
chronicled by Robert Pastor, was all but an illusion for structural Marxists. It led to no real change in U.S. policy as the statistical evidence showed.

$$
\text { Regional Analysis of U.S. Actions in Afghanistan }
$$

\section{Section Introduction}

Chapter four showed that the Soviets did everything in their power to avoid an invasion into Afghanistan. State Department archives show that the Soviet Bloc was also not planning to spread its influence towards the Persian Gulf. However, rather than take this analysis into consideration, the archival evidence of U.S. actions in this region during the late 1970's suggests that certain bureaucratic agencies, such as the NSC and CIA, were engaging in actions that would destabilize the situation in Afghanistan. Indeed, there is considerable archival evidence that U.S. policymakers in the CIA and the NSC, helped incite the Afghan Islamic insurgency during the late 1970's, through indirect and direct aid mechanisms, thereby helping to ignite the Soviet invasion in the first place.

\section{The Bureaucratic Battle}

The evidence suggests there was a bureaucratic battle brewing at the top between the State Department and the NSC/CIA. More specifically, there were intense disagreements between Vance and Brzezinski in regard to Soviet motives in Afghanistan. Following on the advice and facts laid out by the U.S. embassy in Kabul (and the State Department in general), Vance argued in favor of diplomacy with the Soviet Union. He disregarded Brzezinski's previous argument that the April 1978 coup in Afghanistan was part of a Soviet drive to achieve hegemony in Southwest Asia since the U.S. "had no evidence of Soviet complicity in the coup" (Galster, para. 9). He also trusted the counsel given by his Assistant Secretary of State for Near Eastern and South Asian Affairs, 
Harold Saunders, who argued in a recently declassified document that "we need to take into account the mix of nationalism and Communism in the new leadership and seek to avoid driving the new regime into a closer embrace with the Soviet Union than it might wish" (Galster, para. 5)

Brzezinski, however, scoffed at Vance and the State Department's suggestions.

Gary Newsom, Undersecretary of State for Political Affairs, chronicles how Brzezinki:

had a much more confrontational view of the situation than Vance and most of us at the State Department. He thought we should be doing something covertly to frustrate Soviet ambitions. On some occasions, I was not alone in raising questions about the wisdom and feasibility of what he wanted to do. (Harrison, para. 4)

Still, Brzezinski firmly believed that recent actions by the Soviets in the region suggested they "might turn Afghanistan into a launching pad for aggression in the region" (Galster, para. 2).

Brzezinski's desire for an aggressive U.S. response begins in the early months of 1979 as he "pushed a decision in April of 1979 through the Special Coordination Committee (SCC) of the National Security Council...to be, as he put it, more sympathetic (through the use of covert aid), to those Afghans who were determined to preserve their country's independence" (Galster, para. 7). Aggravated by the State Department's cooperative approach toward the Soviets in Afghanistan, which was currently holding sway with President Carter, the April 1979 decision begins the process of altering U.S. policy in the region. Gone was the cautious policy of the past. U.S. policy now shifted toward organizing the Afghan rebels and sending covert assistance.

The true significance of the April 1979 NSC SCC decision was that Brzezinski was able to transfer control of the CIA from the State Department over to the NSC 
(White House is technically in charge of the NSC, but State had been in charge of supervising it under President Carter). Brzezinski himself chronicles how he was able to convince President Carter to transfer control over the CIA from the State Department to the NSC in 1979 (Galster, para. 7). He was very tired of the naïve foreign policy approaches of the State Department in Afghanistan as well as other areas of the world. Ironically enough, Brzezinski was actually able to pressure the State Department to shift their tone on Afghanistan. Indeed, he more than:

"convinced State Department officials that the rising Soviet influence in Afghanistan threatened American national security. He also got them to see that the Afghan situation presented a valuable political opportunity for the U.S. As a State Department report later put it, "the overthrow of the D.R.A. would show the rest of the world, particularly the Third World, that the Soviets' view of the socialist course of history as being inevitable is not accurate" (Galster, para. 9).

Brzezinski's new leadership of the NSC, State, and the CIA was instrumental in helping to provide covert assistance to the Afghan rebels. His new leadership coincides with the CIA and State providing covert military assistance to the rebels several months before the Soviets invaded (Galster, para. 11). Covert assistance, as an October 301979 field report from the CIA documents, was pushed forward by securing the allegiance of Pakistani military officials (Galster, para. 10). The CIA also helped the Afghan rebels secure funding from China and other U.S. allies. Overall, it was pretty obvious that the CIA was determined to provoke the Soviets. Why else would CIA officials fail to repudiate suggestions by "conference participants (organized by the Cold War International History Project) that a U.S.-funded arms pipeline was in place as early as August of 1979" (Ostermann, page 140)? 
High-level officials from Pakistan also suggest that the CIA began to aid the

Afghan Islamic insurgents several months before the Soviets decided to invade

Afghanistan. According to a former Pakistani military official who was interviewed in

1988:

the U.S. Embassy in Islamabad had asked Pakistani military officials in April 1979 to recommend a rebel organization that would make the best use of U.S. aid. The following month, the Pakistani source claimed, he personally introduced a CIA official to Hekmatyar who, while more radically Islamic and anti-American than most Afghans, headed what the Pakistani government considered the most militant and organized rebel group, the Hizb-i Islami (Hekmatyar). (Ostermann, p. 142)

More than anything, Brzezinski's response to a question by a reporter from "Le Nouvel Observateur" in 1998 about whether he regretted his actions in regards to Afghanistan says it all. Brzezinski responds to the reporter by stating:

Regret what? That secret operation was an excellent idea. It had the effect of drawing the Russians into the Afghan trap and you want me to regret it? The day that the Soviets officially crossed the border, I wrote to President Carter: We now have the opportunity of giving to the U.S.S.R. its Vietnam War. Indeed, for almost 10 years, Moscow had to carry on a war unsupportable by the government, a conflict that brought about the demoralization and finally the breakup of the Soviet empire. (Information Clearinghouse, para. 6)

Brzezinski also explains that U.S. advisor Robert Gates account of the events in Afghanistan was right on the mark. He agrees that while the official version of history states that CIA aid to the Mujahadeen began after the Soviets invaded Afghanistan " the reality is completely otherwise: Indeed, it was July 3, 1979 that President Carter signed the first directive for secret aid to the opponents of the pro-Soviet regime in Kabul" (Information Clearinghouse, para. 2). 


\section{Section Conclusion}

It is ultimately quite telling that I found extensive U.S. documents (in the last chapter) from the U.S. embassy in Kabul, part of the less hawkish State Department, initially portraying the Soviet Union's actions as defensive while I now find Brzezinski and his supporters in the CIA and NSC taking control over the State Department and engaging in covert actions (with Brzezinski's lead) against the U.S.S.R. Brzezinski completely overrode Vance and the rest of the leadership in the State Department. After all, "not all U.S. officials believed that the Soviet intervention was part of an expansionist drive... [these officials] advocated quiet diplomacy with the Soviet Union in order to provide the Kremlin with a way out of what they believed was a political and military miscalculation" (Galster, para. 8). It was Brzezinski's ability to influence President Carter that shifted the dynamics in this region. Overall, Brzezinski's ability to influence President Carter, of course, lends immense credibility to the theory of domestic politics.

Structural Marxists would not be surprised that the U.S. became aggressive. For one, they would argue that the U.S. tried to compensate for the loss of Iran in the Buffer Zone. More importantly, they would argue that the U.S. was aggressive and was trying to weaken the Soviets in their backyard.

Regardless, it is obvious that balance of threat theory has been weakened yet again. The evidence firmly shows that the U.S. was aggressive during a time in which the Soviet Bloc was playing cautious. 


\section{The Strategic Arms Race}

Besides whether or not the Soviets were making significant gains in the less developed world, there were also battles within U.S. intelligence agencies in regards to the question of whether or not Détente collapsed due to Soviet advances in the strategic arms race. Vance and Brzezinski deal with this topic.

Trusting that the U.S./Western Alliance had significant deterrents in place, Vance (1983) argues in his memoirs that the Soviets had not turned the strategic nuclear arms race in their favor. He confidently believed that the Soviets were putting their best foot forward and countered his critics by stating that the SALT II arms limitation treaty was a "balanced, carefully wrought set of agreements" which would lead to "SALT III and to negotiations leading to much deeper reductions and increased qualitative constraints on intercontinental nuclear weapons" (Vance, 1983, p. 135).

Hardliners, such as Brzezinski, were instead concerned that the Soviets were coming very close to being successful in their attempt to "politically decouple" Western Europe from the U.S. in the strategic arms arena ("NFAC Bi-Monthly Summary on Soviet Affairs", p. 3). "NFAC Bi-Monthly Summary on Soviet Affairs", a report from William Odom of the CIA to National Security Advisor Brzezinski in October of 1979 (prior to the Soviet invasion), suggests this was the case. Taking advantage of the "erratic nature of U.S. policy" the Soviets were able to paint themselves as the sole superpower that wished to pursue nuclear peace and "military détente" in Western Europe. As argued by a CIA report from early December of 1979, the Soviets were "encouraged that their diplomatic pressure had provoked left-wing and center-left political sentiment throughout 
European NATO in favor of an arms control dialogue with the U.S.S.R." ("Possible Soviet Responses to an Affirmative NATO Decision on TNF Modernization”, p. 4).

The Soviet invasion of Afghanistan changed everything however. The U.S. hardliners realized that invasion had brought some major benefits for the U.S. within the domain of the strategic arms race. Initially failing in its push to get Europe to modernize the West's long-range theater nuclear forces (LRTNF) in Europe, the Soviet invasion of Afghanistan" pushed Western Europe to sign off on the U.S.'s proposal to augment the Western alliance's LRTNF ("Likely Soviet Approach to Preliminary Exchanges on TNF", p. 6).Western European countries, such as West Germany, Belgium, and the Netherlands were now, unlike in the prior year, pushing harder and harder for the increase of longrange theater nuclear forces in the European continent. The "disarray of the Alliance over enhanced-radiation weapons" several years ago no longer existed.

The tightening of the Western Alliance during the early months of 1980 surprised and worried the Soviets. Soviet leaders contested that "new NATO forces will be able to destroy targets up to the Volga line-beyond the heart of the Soviet military infrastructure" (“Likely Soviet Approach to Preliminary Exchanges on TNF”, p. 6). Soviet leaders believed the NATO improvements gave a significant advantage to the West. Unlike the theater nuclear improvements made by the U.S.S.R., which were only qualitative improvements in the forces with the same combat tasks, the Soviets contested that Western improvements in LRTNF were quantitative improvements in the arsenal of the West. Accordingly, the CIA warned that the Soviets would intensify their diplomatic dialogue hoping that it "would serve as evidence that U.S.-Soviet détente was still viable, thus making the West Europeans more willing to conduct business with them as usual" 
("Likely Soviet Approach to Preliminary Exchanges on TNF", p. 4). However, the Soviet diplomatic push did not succeed.

As a matter of fact, in contrast to the initial arguments made by U.S. hawks that the U.S. was losing the strategic nuclear balance in the late 1970's, Carter Administration documents suggest that U.S. was strategically much stronger in the strategic arms race during the final years of Détente. In fact, the Carter Administration boasted that NATO military strength had significantly improved between 1977 and 1979. No longer was NATO military strength in Europe "eroding in the face of an increased Soviet threat (as the report claims was happening in 1977)" ("Likely Soviet Approach to Preliminary Exchanges", p. 3). On the contrary, Carter Administration documents contend that the U.S. was able to reverse the trend. The administration argued that the "1977 and 1978 NATO Summits led to the adoption of the NATO Long-Term Defense Program....These commitments (more military spending) brought about improvements in Alliance capabilities and will have a major impact in the future" ("Likely Soviet Approach to Preliminary Exchanges", p. 3).

Not only has balance of threat of threat theory been weakened (asymmetrical realism), but the findings relating to strategic arms have also weakened symmetrical realism. Détente did not collapse due to Soviet gains in this arena. The evidence shows the U.S. made gains while Soviet capabilities decreased.

U.S. Archives and the Deterioration of the Western Bloc during the 1970's

\section{Section Introduction}

Since balance of threat realism has been severely weakened in chapters four and five, I will now introduce archival documents pertaining to the Western Bloc. Such 
documents are immensely significant for structural Marxists. For them, they show the U.S. significantly worried about the chasms within the Alliance.

Structural Marxists would contend that the U.S. was pursuing the structural economic interests of U.S. capital. They firmly disagree with realists in regards to U.S. motivations in the less developed world. Rather than responding to the Soviet threat, structural Marxists firmly believe that the U.S. was most concerned with the rise of its fellow allies in the Western Alliance and the effect of that competition on U.S. interests in the Third World. Structural Marxists would argue that the U.S. push against the Soviet Bloc during the late 1970's was an attempt to re-assert its influence within the West in their endeavor to continue Western cumulative superiority over the U.S.S.R. and the less developed world. In fact, they would argue that Brzezinski pushed to link Western Europe and Japan closer together during the late 1970's as he feared that the U.S. was losing the leadership mantle of the Western Alliance (Brzezinski, 1983, p. 148). As I discussed in the first chapter, a tight relationship with Western Europe and Japan was a significant cornerstone of U.S. policy. After all, if the U.S. was worried that Soviet Détente diplomacy was starting to "politically decouple" Western Europe from the U.S., then it would surely worry if events in the less developed world were starting to economically decouple Western Europe from the U.S.

Indeed, U.S. archives reveal that Japan and Western Europe's increasing economic strength, their activities in the less developed world, and the perceived weakness of the U.S. to defend the "status quo" were all significant concerns for the U.S. in the late 1970's. The archives also suggest that Europe was becoming too independent and much more willing to challenge/question the U.S. than ever before. Taken as a 
whole, these occurrences frightened U.S. leaders from all significant U.S. intelligence agencies, and brought concerns about the long-term viability of the Western Bloc. U.S. Archives and the Cracking of the Western Alliance during the 1970's

To gauge the U.S.'s interpretation of its relations with the rest of the Western Alliance I shall begin with a blunt 1979 CIA report entitled "Changing Power Relations among OECD States". "Changing Power Relations among OECD States" argues "that greater independence or initiative" on the part of the Western Europeans and the Japanese occurring during the late 1970's occurred due to the loss of U.S. leadership, especially within the economic arena (p. 2). The report also argues that Western European and Japanese partners were becoming (throughout the 1970's) much more resistant to U.S. economic initiatives ("Changing Power Relations", p. 2). In the past, U.S. allies had "no choice but to accept U.S. leadership, even if they worried that some American decisions might not be in their best interests" (“Changing Power Relations", p. 2). However, thanks to a persistent "U.S. effort throughout the post-war period to enhance its partner's military and economic capabilities (to woo them away from the Soviet Bloc)," as well as the general decline in American political, economic, and military power, the report goes on to argue that U.S. allies now "believe that their capabilities go far beyond resistance, and that their interests increasingly demand that they seize the initiative or even act independently" (“Changing Power Relations", p. 3).

Most importantly, the report contends that U.S. dominance over the West's strategic arsenal no longer resulted in European acquiescence in the economic arena. The "spillover" effect that the U.S. gained from military issues into other areas was now 
voided ("Changing Power Relations", p. 6). Economic assertiveness on the part of the U.S.'s allies was now a reality.

The most glaring economic concern in the report revolves around Western European and Japanese relations with the less developed countries. The report affirms that allied (economic) activities "in Latin America, the Middle East, and South Asia have already caused considerable friction with the U.S., and threatens to cause more in the future" ("Changing Power Relations", p. 8). Such activities include the French and Germans selling nuclear technology to less developed countries not allied with the U.S. and the Western Europeans establishing bilateral ties in the Middle East region (to the exclusion of the U.S.) (“Changing Power Relations", p. 8). The report perceives Germany to be one of the most worrisome cases. No longer ready to do the "bidding of the U.S.," Germany "is [was] increasingly pursuing independent political-economic interests (in Brazil for instance) and working at persuading its EC colleagues to join in its policies designed to advance their common interests" "“Changing Power Relations", p. 11). In regards to OPEC and other rapidly developing countries the 1979 CIA report cites concerns that the "allies are pursuing their national interests there aggressively, while paying relatively limited attention to the possible global strategic implications of their actions." Thus, Western Europe and Japan's moves to form closer ties with the semiperiphery and OPEC nations also concerned U.S. leaders in regard to the viability of the Western Alliance.

There are additional economic examples of the Western Europeans and Japanese taking on a more assertive role against the U.S. Within the OECD macroeconomic arena, which the U.S. had historically dominated, the report finds that France and West 
Germany launched the European Monetary System (EMS) in order to "provide some exchange rate stability." These Western European countries took this initiative as they felt that U.S. economic and fiscal mismanagement was the cause of international monetary disorder ("Changing Power Relations", p. 4). The Europeans also pressured the U.S. to adopt anti-inflation and dollar support programs ("Changing Power Relations", p. $4)$.

The U.S. economic problems (loss of energy self-sufficiency, loss of U.S. productivity, and economic mismanagement) also brought forth allied concerns about "America's freedom of action in foreign policy and military affairs ("Changing Power Relations", p. 10). For instance, the military decline of the U.S. sparked concerns about U.S. resolve against the Soviet Bloc and areas of strategic concern to the alliance in the less developed world. Germany and the Europeans worried about Soviet gains in the strategic arena. The Japanese feared that U.S. troops would slowly begin to disengage from nearby South Korea (“Changing Power Relations”, p. 10).

More than that, the U.S.'s decline and inability to display firm leadership was causing U.S. allies to become increasingly resentful of relying on the U.S. for military leadership and protection when considering the "disparity between their growing economic strength and their military weakness" (“Changing Power Relations”, p. 13). The lack of U.S. leadership caused many within the Western Alliance, specifically West Germany, and Japan to consider the unprecedented step of making an accommodation with the Soviet Bloc ("Changing Power Relations", p. 13).

The basis and starting point for U.S. suspicion about the strength of the Western Alliance comes from the 1973 October War. As mentioned in the Middle East section of 
this chapter, this conflict witnessed the rise of an intense friction between the U.S. and its European allies over the degree of European assistance (or lack thereof) during this conflict. An October 26, 1973 meeting between U.S. Secretary of State Kissinger and German ambassador Von Staden finds Kissinger chiding the Europeans. He comments that:

It is the overall position of our allies that raises the most serious questions. Time and time again we have offered to consult and work out our common positions. What we receive is conspicuous dissociation of our allies. We think we are engaged in a common exercise to defend our common interests. What we have in the present instance is two weeks of intense crisis in which we sought to discourage Soviet adventurism. These are the facts however one views the merits of Israeli policy now and over the past six years. Once the war started it was in no one's interest to see the Israelis defeated. ("The October War and U.S. Strategy", document \#81, p. 2)

Kissinger continued further and blasted European capitulation to the Arabs. He tells the German Ambassador that:

such disassociation (Europeans pushing for a cease-fire between Israel and the Arabs at a time when Israel was weak)... [will] not result in their insuring their oil supply, but it can have disastrous consequences vis-à-vis the Soviet Union, who if allowed to succeed in the Near East, can be expected to mount more aggressive policies elsewhere. To the degree that Soviet influence can be reduced, we will gain a long term advantage if we pay a short term price. ("The October War and U.S. Strategy", document \#81, p. 2)

Ultimately, Kissinger firmly believed that European consultations with the Soviets and their push to have them help arrange an early cease-fire were to the long-term detriment of the Western Alliance. As a result, Kissinger stated that the "general attitude our European allies have adopted is an issue. It is one that profoundly concerns us. It has happened with too much consistency too many times" ("The October War and U.S. Strategy", document \#81, p. 4). 
As the U.S.'s Middle East archives show, the U.S. was still able to take the lead (through Kissinger's scuttle diplomacy) and ensure an outcome that would be beneficial for the West and its leadership within it. However, U.S. leaders remained concerned about the looseness of the Western alliance throughout the rest of the 1970's. The issues presented above, such as the continuing economic deterioration of the U.S., the economic rise of its Western allies, and increasing nationalism in the less developed world, still haunted U.S. policymakers.

However, U.S. policymakers understood that the Western Europeans and the Japanese lacked the political will (at that specific time) to make the necessary domestic economic adjustments to create their own independent sources of military power (“Changing Power Relations", p. 13). In regard to Japan, while the Japanese Defense White Papers always called for significant increases in military spending, the CIA report states that their leaders knew and accepted the fact that the public would only agree to very moderate increases in military spending ("Changing Power Relations", p. 14). Secondly, the Europeans really did want the U.S. to remain militarily in charge of the Western Alliance. The European public certainly did not wish to turn in their universal health care.

Most significantly, the Europeans and Japanese were not about to enter (at that time) into any type of strategic military alliance with Saudi Arabia or Iran and they still desired U.S. leadership when confronted with communist threats in the Third World (“Changing Power Relations", p. 12). The Western Europeans and Japanese still had much more in common with the U.S. than with the U.S.S.R. or developing nations. The 
result was "an alliance in transition...characterized by both continuity and change" (“Changing Power Relations”, p. 4).

For these reasons, the report contends that the Western Alliance could be secured and straightened should the U.S. take into account the changed power dynamics and help guide them in the right direction (as the U.S. did during the 1973 October War). The report implies rational-choice/game theory as the solution by stating that, "an alliance of more equal partners could eventually prove stronger than one under American dominance. But such a positive outcome would require major changes in the OECD decision-making processes, based on substantial alterations in the allies' behavior and expectations" ("Changing Power Relations", p. 2). A collapse of these institutionalist ends would result in "an essentially leaderless OECD with a substantial increase in uncertainty, complexity, and friction on basic political, military, and economic issues" (“Changing Power Relations", p. 2). In the end, large-scale aggressively competitive actions, either within the military or economic realm, against alliance members would prove to be against the interests of alliance members ("Changing Power Relations", p. $13)$.

\section{Section Conclusion}

As a result, structural Marxists would point to these U.S. documents and suggest that U.S. maneuvers in the late 1970's, leading to Détente's collapse, were the result of the U.S. trying to re-assert itself as the leaders of the West. The U.S. needed to take control of Europe and Japan's attempt to make gains in the less developed world as well as stop Europe and Japan from developing their own military alliances. The Soviet Bloc was simply used as the scare tactic to rally the West in regard to foreign policy. The 
Soviet scare tactic, and not the facts regarding how the less developed world was pursuing nationalism and interests' independent of Soviet action, was also used as domestic consumption to rally the American people to support U.S. incursions abroad.

Certainly, harping on the less developed world suggests that the U.S.'s main concern during this time period dealt with how events in the less developed world were affecting the U.S.'s position in the new multi-polar world order. None of this should be any surprise considering that the core philosophical underpinnings of Détente for the U.S. (according to a State Department report) dealt with responding "to multipolarity and relative U.S. decline" ("Foreign Relations of the U.S.", para. 16). Kissinger and Nixon had already argued that the "bipolar structure of the Cold War, in which only two superpowers held a preponderance of power" was now over (Foreign Relations of the U.S. para. 15).

\section{Section Introduction}

\section{Conclusion}

The U.S. archival analysis of U.S. actions during the late 1970's showed that the U.S. was very aggressive in all of regions in the world. Whether through economic/political means (Asia, Latin American), political/military means (Middle East), or just military means (Afghanistan, Africa), the U.S. used various forms of power at its disposal in an attempt to successfully reduce Soviet influence in the region. Even in the strategic arms domain, the U.S. was able to turn the tide against the Soviets. Indeed, the most hawkish U.S. official at the time, Carter's National Security Advisor Zbigniew Brzezinski, noted that while the Soviets were making "significant advances....in Ethiopia and Angola.....such advances should be measured against the success of our policies vis- 
à-vis ASEAN, India, Nigeria, Latin America, and the PRC (China)" ("Summary of Dr. Brzezinski's Meeting with Foreign Minister Sunao Sonoda”, p. 4).

Policymakers in the U.S. justified their actions as legitimate attempts at reducing Soviet power. Still, such an analysis is questionable. The previous chapter, which analyzes Soviet actions in the region, has U.S. archives suggesting the Soviets were very cautious in most of the regions in the world. This suggests that the U.S. was perhaps not truly responding to Soviet interventionism.

Such a theory is given credence by U.S. archives relating to Western Europe and Japan. These archives show the U.S. to be extremely worried that Western Europe and Japan were starting to go their own way economically and politically. Europe's actions during the Arab-Israeli conflict were but one example of this. The archives showed Henry Kissinger extremely worried that Europe was no longer a valuable member of the Western Alliance. However, before I turn to these archives, I shall first summarize my regional findings.

\section{Regional Findings Summary}

My analysis of U.S. Asian archives correlates perfectly with those in chapters three and four. They show that the U.S. worked with the economically rising ASEAN countries, China, and Japan to completely counter against the perceived Soviet gains of Vietnam, Laos, and Cambodia. Not only did U.S. agencies believe this was the case, but they went further and suggested that the U.S. was gaining the upper hand in the region. Document after document from the State Department showed just how cooperative the U.S. relationship with ASEAN had become. They show the U.S. making political and economic gains during the late 1970’s. 
On the military side, I found that President Carter, Brzezinski, and the NSC arguing that the U.S. balance of power position, primarily in the military realm, had significantly improved in favor of the U.S. during the late 1970's. The archives also show the Department of Defense much more content during the late 1970's as compared to several years earlier with the balance of power. Increases in the U.S.'s military spending in the Pacific theater brought this about. Most importantly, U.S. archives showed that the intensification of the Sino-Soviet split was judged to be the biggest nuisance for the U.S.S.R. in the region. Rather than seeking to create instability, U.S. archives show that “the overarching motivation of Soviet policy (during the late 1970's) remained the isolation of China, with Vietnam as the U.S.S.R.'s most important anchor" ("Soviet Goals and Expectations in the Global Power Arena”, p. 38).

The U.S.'s archives relating to the Middle East also match very nicely with those in chapters three and four. They point to large-scale evidence of the U.S. making gain after gain "in the part of the Third World of greatest concern to the Soviet Union" ("Soviet Goals and Expectations in the Global Power Arena”. p. 36). More specifically, the U.S. also (through Kissinger) did everything within its power to strip Egypt away from the Soviet orbit. This all began with the 1973 Arab-Israeli war between Egypt and Israel. U.S. archives showed Kissinger using all leverages at his disposal to secure an outcome that would all but eliminate Soviet influence in the region. My archival analysis of U.S. agencies also showed significant synchronization. No U.S. agency argued that U.S. actions in the region, in regards to pulling Egypt away from the U.S.S.R., were risking war and the collapse of Détente. Instead, U.S. agencies worked to secure Egypt's turn to the West. 
The examination of Sub-Saharan Africa provides a similar result. The archives (U.S. and Cuban archives) show that the principal instigator, through the use of covert military activities, of the Angolan civil war were none other than the U.S. and South Africa. The U.S., with the help of the CIA and the NSC, worked with China and other Soviet enemies in an attempt to weaken the MPLA. Rather than push for diplomacy and work in an honest fashion, as promoted by the State Department, the evidence suggests the U.S. was willing to do anything to prevent the MPLA from gaining a foothold in the government. Officials in this State Department did not believe this approach would advance U.S. interests in the region. However, the NSC and the CIA were successful in their aggressive approach that eventually pushed the Cubans and the Soviets to aid the MPLA.

These findings eliminate the possibility, left open in chapter three and four, that the Soviets may have been aggressive in this region. For instance, chapter three showed that the Soviets allocated a lot of military assistance but did not corroborate such assistance with the economic assistance necessary to help the regimes in Angola and Mozambique consolidate control over their countries. Chapter three also showed that the Soviets did not move into Southern Africa until the collapse of the Portuguese empire. Nevertheless, U.S. covert actions in this region together with the last chapter's argument that the Soviets were cautious in this region, suggests the U.S./West was the aggressive superpower Bloc.

The archival analysis of Latin America showed that the U.S. did not alter its policy of aiding economically and politically repressive regimes in the region. Although admitting that such assistance was causing revolutionary turmoil in the region, which 
would only aid the Soviets, the Carter administration did not significantly cut funding to those who violated human rights in the region. Quite the contrary, "Presidential Review Memorandum NSC-28: Human Rights" tilted the balance sheet in the favor of a cautious U.S. approach (p. 3). It argued the U.S. should tread lightly with its allies in the region as many of them were politically and economically significant for U.S. interests in the region.

It also seemed that U.S. agencies were on the same page in regards to U.S. policy in the region. I did not find evidence of inter-agency conflict during most of the late 1970's. However, conflict arises after the Nicaraguan revolution between the State Department and the more hawkish agencies (Defense, NSC). The State Department argues in favor of an aid package and diplomacy while the more hawkish agencies pushed for aggression.

These findings help liquidate the possibility, left partially open in chapter three, that the Soviets may have been aggressive in Latin America. I showed in Chapter three that the Soviets sent more military assistance to Cuba than the West did to Central America. However, the archival findings in chapter four showing Soviet caution and the findings in this chapter showing U.S. aggression eliminate the doubt I had of whether or not the Soviets were more aggressive in this region than the U.S./West.

The study of Afghanistan shows the U.S., through the work of the NSC and the CIA, pushing to aid Islamic fundamentalists in Afghanistan several months before the Soviets invaded. US officials Brzezinski and Gates, as well as other Pakistani and U.S. sources, confirm that the U.S. (or the hawks at least) wished to involve the Soviet Union in a costly war. This completely went against the advice and counsel of the State 
Department. According to State Department archives examined in the last chapter, the Soviets were doing everything in their power to not invade Afghanistan. However, Brzezinski was able to reduce the power of the State Department and increase the power of those with more hawkish views. This was done by convincing President Carter to turn over the reins of leadership (supervisory role) of the NSC's SCC over to Brzezinski.

Together with chapters three and four, these findings support the argument that the U.S./West was more aggressive than the Soviet Bloc in the Buffer Zone during Détente. Chapter Three found little evidence of Soviet military aggression. The Western Bloc was sending more military and economic aid to the strategic parts of the Buffer Zone than the Soviets. I also mentioned that chapter four witnessed the State Department pleading that the U.S.S.R. was doing everything in their power to avoid an invasion. Strategic Arms Summary

The U.S. archives also showed that the strategic nuclear balance was turning against the Soviet Bloc and in favor of the West. The Carter administration had successfully pushed to re-arm and re-strengthen the NATO alliance through significant military spending increases. From conventional to strategic arms deterrence, the archives showed a U.S. resilience to gain an edge in the strategic nuclear balance.

More success in this domain was found when the Soviets invaded Afghanistan. Ironically occurring due to the work of the hawkish U.S. agencies that were warning about increasing Soviet strengths in the strategic nuclear arms arena, the war in Afghanistan actually helped unify the Western Alliance. Western European governments were no longer balking at U.S. proposals to increase strategic arms capabilities. Perhaps one can say that the U.S. knew which buttons to push. They knew that successfully 
painting the Soviet bear as an expansionist nemesis that threatened Western Europeans would turn the Europeans away from diplomacy with the Soviets.

\section{Reducing Soviet Gains?}

The overall thrust of these regional and strategic arms findings by U.S. intelligence agencies is that the U.S. was now turning the corner and significantly reducing Soviet gains during the Détente throughout the less developed world, increasing U.S./Western gains, and increasing U.S./Western strategic power. Nevertheless, the suggestion that U.S. foreign policy revolved around curtailing Soviet expansion breaks down when one considers that U.S. archives (along with the quantitative foreign aid data) already showed the Soviets were cautious throughout the less developed world during the 1970's. After all, the archives strongly show that the events in Latin America and the Buffer Zone had nothing to do with the Soviet Bloc. Perhaps they had something to do with revolutionary turmoil and the aspirations of local actors fighting for social change. U.S. Archives and the Interpretations of Structural Marxism, Domestic Politics, and Balance of Threat Realism

Conflict within the Western Alliance, as a result of revolutionary turmoil, is the cornerstone argument of many within the structural Marxist camp. They firmly believe that the decline of the U.S. vis-à-vis other Western powers in the 1970's propelled the less developed to rise up against injustice. In turn, the other core states, such as those in Western Europe, seeing that the dominant core was declining would seek opportunities for gains in the less developed world at the expense of the core (as the quantitative evidence showed in South America). 
Indeed, U.S. archives showed that deteriorating U.S. relations with the Western Alliance was a major concern during the 1970's. A 1979 CIA report entitled "Changing Power Relations among OECD States" argued that Western Europeans and the Japanese were becoming much more economically and politically independent ("Changing Power Relations among OECD States", p. 2). While U.S. allies previously had "no choice but to accept U.S. leadership, even if they worried that some American decisions might not be in their best interests," quick submission to the U.S. was no longer in play ("Changing Power Relations among OECD States", p. 2). The Europeans and Japanese were now much more willing to take the initiative in many facets of the economic arena as well as in the less developed world. For U.S. policymakers, such European actions were ultimately detrimental to the Western Bloc.

Therefore, Structural Marxists would further contend that conflict in the less developed was causing the U.S. to worry that nations in the Third World would turn to the new emerging multi-polar world order (other Western nations) for assistance. After all, U.S. archives point to significant U.S. concerns in Latin America during the 1970's. U.S. policymakers were concerned that poverty and repression, not Soviet meddling, was unleashing revolutionary activity in the less developed world. It explains why the U.S. took a very aggressive approach in the Middle East and Asia. The U.S. wanted to control the situation in the 1973 October War in order to bring Europe back into the fold. Therefore, U.S. actions ultimately had nothing to do with the Soviet Bloc and everything to do with Europe and the less developed world.

Supporters of structural Marxism would point out that Kissinger and Nixon had already argued that the "bipolar structure of the Cold War, in which only two 
superpowers held a preponderance of power" was now over ("Foreign Relations of the U.S. 1969-1976", para. 15). The era of Détente, now involved responding "to political multipolarity" and relative U.S. decline ("Foreign Relations of the U.S. 1969-1976", para. 16). The actions described above are how the U.S. dealt with its decline. It sought to remain in charge of the Western Alliance and continue to reign as the leader of the multipolar capitalist order. U.S. actions ultimately had nothing to do with the Soviet Bloc and everything to do with reining in Europe and the less developed world.

Proponents of domestic politics would point to Afghanistan, Asia, Southern Africa, and Latin America as evidence that U.S. foreign policy revolved around interagency conflict. They would contend that various branches of the U.S. intelligence community were captured by certain interest groups/business groups in an attempt to promote their interests. These scholars would look at Afghanistan and Southern Africa and cite the evidence showing the State Department pushing for a cautious approach while the NSC and the CIA were engaging in covert operations. They would also cite the immense influence of Secretary of State Kissinger and Brzezinski during the Ford and Carter administrations as having immense influence over U.S. actions in Angola and Afghanistan.

They would also point to Asia and show how the State Department was concerned with developing ASEAN while the more hawkish agencies were more concerned with increasing U.S. naval and air power. While serious conflict did not occur between U.S. agencies in this region, as compared with Afghanistan, backers of domestic politics would argue that the potential for fierce conflict was there. It was only subdued by the fact that each agency got to push their respective approaches at the same time. These 
theorists would also look at Latin America and suggest that serious conflict erupted once the Sandinistas achieved victory in Latin America.

I have chronicled how structural Marxists would dismiss this. They would argue that the State Department did not push for a cooperative approach when they had a chance. However, supporters of domestic politics would argue that the inertia of U.S. foreign policy worked against President Carter. It is very difficult for the U.S. to alter its foreign policy. In rebuttal, supporters of domestic politics would argue that the doves only stood up (in the case of Nicaragua) when a significant opportunity to alter U.S. policy finally emerged.

Balance of threat realist theorists would dismiss the interpretations provided by structural Marxists and supporters of bureaucratic politics. They would argue that these theories only explain things at the periphery. American foreign policy, in their view, was the result of the U.S. trying to reduce the rise of the Soviet Bloc.

The overwhelming evidence finally pushes me to dismiss this theoretical approach. Perhaps there were many members of the State Department (and other more dovish agencies) that did firmly adhere to the tenets of balance of threat theory. However, the actions of the more dominant agencies take me in a different direction. The hawks did not believe in balance of threat realism. What did they believe in? The conclusion will now try to answer this question. The foreign aid and archival data have driven me towards the theories of structural Marxism and domestic politics. 


\section{REFERENCES}

"Afghanistan: Lessons from the Last War; National Security Archives"; October 9, 1979. Retrieved August 2008 from:

http://www.gwu.edu/ nsarchiv/NSAEBB/NSAEBB57/essay.html

Alterman, J. (2005). "Dynamics without Drama: New Options and Old Compromises in Egypt's Foreign Policy”. Cambridge Review of International Affairs, Volume 18, pp. 355-372

Brzezinski. Z. (1983). Power and Principle: Memoirs of the National Security Adviser, 1977-1981, Farrar, Strauss, and Giroux

"Changing Power Relations among OECD States" (NLC 7-16-10-14-1); Records of the CIA; October 22, 1979; Jimmy Carter Presidential Library, Atlanta, GA.

"Conversation with Minoru Tampa on Military Relations" (JA00471) [Electronic Records]; Records of the U.S. Department of Defense; Japan and the U.S., 1977-1992; December 11, 1978; National Archives at College Park, College Park, MD.

Cox, R. (1994). Power and Profits: U.S. Policy in Central America. University of Kentucky Press

Davis, N. (1978). “The Angolan Decision of 1975: A Personal Memoir”, Foreign Affair. Retrieved July 2007 from:

http://fullaccess.foreignaffairs.org/19780901 faessay9886/nathaniel-davis/the-angoladecision-of-1975-a-personal-memoir.html

"Egypt: Efforts to Support the Shah of Iran" (IR03588); Records of the Defense Intelligence Community; Iran Revolution; November 15, 1978; National Archives Building at College Park, College Park, MD.

"Establishment of U.S. Sinai Support Mission" (PR00255); Records of the U.S. National Security Council; Presidential Directives Part II; November 14, 1975, National Archives at College Park, College Park, MD.

French, H. "New View of U.S. role in Angola": Documents tell a different story than memoirs of Kissinger; New York Times; March 31, 2002; Retrieved June 2007 from http://www.sfgate.com/cgibin/article.cgi?file=/c/a/2002/03/31/MN102233.DTL\&type=printable

Fagen, R. (1978). "The Carter Administration and Latin America: Business as Usual”, Foreign Affairs, Vol. America and the World Retrieved June 2006 from http://fullaccess.foreignaffairs.org/19790201 faessay9911/richard-r-fagen/the-carteradministration-and-latin-america-business-as-usual.html 
"Foreign Relations of the U.S. 1967-1976"; Records of the State Department; Volume 1; Retrieved June 2006 from: http://www.state.gov/r/pa/ho/frus/nixon/i/21100.htm

Gedda, G. "Ex-CIA Man Criticizes Kissinger; Associated Press"; April 2, 2002; Retrieved February 2009 from http://groups.yahoo.com/group/CubaNews/message/8557?1=1

Galster, S. "Destabilizing Afghanistan". Covert Action. Retrieved June 2006 from http://covertaction.org/content/view/163/75/

Galster, S. "Afghanistan: Lessons from the Last War"; National Security Archives; Retrieved August 2008 from:

http://www.gwu.edu/ nsarchiv/NSAEBB/NSAEBB57/essay.html

Gleijeses, P. (2003). Conflicting Missions: Havana, Washington and Africa, 1959-1976. University of North Carolina Press.

Harrison, S. "How the Soviets Stumbled into Afghanistan". Retrieved June 2006 from http://www.afghanan.net/afghanistan/soviet/Vance\%20versus\%20Brzezinski.html

Harder, M. “The Angolan Involvement”. Washington Post. January 19, 1975

"Honorable Harold Brown Secretary of Defense' (JA00610), [Electronic Records] Records of the U.S. Department of Defense; Japan and the U.S., 1977-1992; October 1920, 1979; National Archives at College Park, College Park, MD.

Information Clearinghouse. "How the US Provoked the Soviet Union into Invading Afghanistan"; Retrieved June 2007 from

http://www.informationclearinghouse.info/article 7323.htm

"Issues Paper on Future Pacific Strategy' (JU01933) [Electronic Records]; Records of the State Department; Japan and the U.S., 1960-1976; May 6, 1975; National Archives at College Park, College Park, MD.

“Kissinger Watch.” Issue 16; March 22, 2002; Retrieved June 2008 from http://www.icai-online.org/kissingerwatch/kw16.pdf

Lebovic, J. (1988). U.S. National Interest and U.S. Foreign Aid. Journal of Peace Research; Vol. 25, pp. 115-135

"Likely Soviet Approach to Preliminary Exchanges on TNF" (NLC 23-58-2-2); Secret CIA report; October 6, 1980; Jimmy Carter Presidential Library, Atlanta, GA. 
"Meeting of the National Security Council: Friday June 27, 1975" (PR01309); [Electronic Records] Records of the U.S. Assistant to the President for National Security Affairs; Presidential Directives II, June 27, 1975; National Archives at College Park, College Park, MD.

"Meeting with State Department Advisors" (KT02054); Records of the U.S. National Security Council; Kissinger Transcripts; September 10, 1976, National Archives at College Park, College Park, MD.

"NFAC Bi-Monthly Summary on Soviet Affairs" (NLC 6-82-1-1-1); Records of the CIA; October 20, 1979; Jimmy Carter Presidential Library, Atlanta, GA.

"Objectives and Goals in Guatemala" (GU00541); Records of the State Department; December 19, 1978; National Archives at College Park, College Park, MD.

Ostermann, C. "New Evidence on the War in Afghanistan"; Cold War International History Project Bulletin; Issue 14/15; 2003. Retrieved on August 10, 2008 from http://www.wilsoncenter.org/topics/pubs/c-afghanistan.pdf

Pastor, R. (1992). The Carter Adminstration and Latin America: A Test of Principle. The Carter Center.

"Possible Soviet Responses to an Affirmative NATO Decision on TNF Modernization" (NLC 23 48-5-2-7); Secret CIA report; December 4, 1979; Jimmy Carter Presidential Library, Atlanta, GA

"Presidential Review Memorandum/ NSC 28: Human Rights"; Records from the National Security Council to President Carter; August 15, 1977; Jimmy Carter Presidential Library, Atlanta GA

Stohl, M., Carleton, D., Johnson, S. (1984). "Human Rights and U.S. Foreign Assistance from Nixon to Carter”. Journal of Peace Research, Vol. 21, pp. 214-230

Slater, J. (1990). “The Superpowers and an Arab-Israeli Political Settlement." Political Science Quarterly, pp. 564-580

"Southeast Asia" (JA 00552) [Electronic Records]; Records of the State Department; Japan and the U.S., 1977-1992; June 4, 1979; National Archives at College Park, College Park, MD.

"Soviet Goals and Expectations in the Global Power Arena" (NIE 11-14-78); Records of the CIA; April 23, 1978; Jimmy Carter Presidential Library, Atlanta GA 
"Summary of Dr. Brzezinski's Meeting with Foreign Minister Sunao Sonoda' (JA00393) [Electronic Records]; Records of White House; Japan and the U.S. 1977-1992; May 24, 1979; National Archives at College Park, College Park, MD.

"Summary of the President's Meeting with Japanese Prime Minster Ohira" (JA0067) [Electronic Records]; Records of the White House; Japan and the U.S. 1977-1992; May 2, 1978; National Archives at College Park, College Park, MD.

"The October War and U.S. Strategy" (Document \#13); National Archives at College Park, College Park, MD. Retrieved September 2006 from: http://www.gwu.edu/ nsarchiv/NSAEBB/NSAEBB98/octwar-13.pdf

"The October War and U.S. Strategy" (Document \#17); Archives at College Park, College Park, MD Retrieved in September 2006 from: http://www.gwu.edu/ nsarchiv/NSAEBB/NSAEBB98/octwar-17.pdf

"The October War and U.S. Strategy" (Document \#18); Archives at College Park, College Park, MD Retrieved in September 2006 from: http://www.gwu.edu/ nsarchiv/NSAEBB/NSAEBB98/octwar-18.pdf

"The October War and U.S. Strategy" (Document \# 51); Archives at College Park, College Park, MD; Retrieved in September 2006 from: Website:

http://www.gwu.edu/ nsarchiv/NSAEBB/NSAEBB98/octwar-51.pdf

"The October War and U.S. Strategy" (Document \#54); Archives at College Park, College Park, MD; Retrieved in September 2006 from:

Website:http://www.gwu.edu/ nsarchiv/NSAEBB/NSAEBB98/octwar-54.pdf

"The October War and U.S. Strategy" (Document \#63); Archives at College Park, College Park, MD; Retrieved in September 2006 from:

http://www.gwu.edu/ nsarchiv/NSAEBB/NSAEBB98/octwar-63.pdf

"The October War and U.S. Strategy" (Document \#65); Archives at College Park, College Park, MD Retrieved in September 2006 from:

http://www.gwu.edu/ nsarchiv/NSAEBB/NSAEBB98/octwar-65.pdf

"The October War and U.S. Strategy" (Document \#67); Archives at College Park, College Park, MD; http://www.gwu.edu/ nsarchiv/NSAEBB/NSAEBB98/octwar-67.pdf

"The October War and U.S. Strategy" (Document \#81); Archives at College Park, College Park, MD; http://www.gwu.edu/ nsarchiv/NSAEBB/NSAEBB98/octwar-81.pdf 
"United States Policy toward Angola" (PR01307) [Electronic Record]; Records of the National Security Council; Presidential Directives II; June 18, 1975; National Archives at College Park, College Park, MD.

"U.S. and Japanese Relations with ASEAN" (JA00294) [Electronic Records]; Records of the State Department; Japan and the U.S., 1977-1992; September 23, 1977; National Archives at College Park, College Park, MD.

"U.S./Japan-USSR Balance" (JA00402) [Electronic Records]; Records of the Department of Defense; Japan and the U.S. 1977-1992; June 12, 1978; National Archives at College Park, College Park, MD.

Vance, C. (1983). Hard Choices: Critical Years in America's Foreign Policy. Simon and Schuster

"Your Visit to Japan" (JA00388) [Electronic Records]; Records of the Department of State; Japan and the U.S. 1977-1992; May, 23-24, 1978; National Archives at College Park, College Park, MD. 


\section{Chapter VI: Conclusion}

\section{Introduction}

My dissertation has directly answered its central research question. Evidence does not support the idea that the Soviet Bloc was aggressive during the final years of Détente in the less developed world. The historical/quantitative evidence, found in chapter three in form of foreign aid expenditures from the U.S. Disarmament Agency's WMEAT, and archival evidence, found in chapter four in the form of U.S. archives, succinctly shows Soviet actions to have been defensive and cautious in nature vis-à-vis the U.S./Western Bloc. On the other hand, the quantitative and archival evidence (chapter five) points to the U.S. (the leader of the Western Bloc) as the aggressive superpower during the late 1970's. But why did the U.S. then become aggressive during the final years of Détente? Why did U.S. leaders so eschew and abandon the principles of Détente (lower military spending, accommodation with the Soviet Bloc) in the late 1970's? There must certainly be a reason for this occurrence.

Thankfully, I not only used the chapters as a test for the central research question, but I also used the chapters as springboards for an examination of which international relations theory best explains why Détente collapsed, why the U.S. became aggressive, and why the U.S. blamed the Soviets when the evidence at hand pointed to Soviet caution? After all, the evidence has rejected balance of threat theory as a plausible explanation. The prediction made by such theorists, based on rising Soviets military expenditures, U.S. military and political decline, and rising revolutionary turmoil during the late 1960's/early 1970 's, that the Soviets would be determined to take advantage of the emerging superpower vacuum in the less developed world was ultimately incorrect. 
Fortunately, however, I was able to use chapters three, four, and five as theoretical examinations for the alternative theories of structural Marxism and domestic politics. Structural Marxism, as I described in my opening chapter, predicted that the evidence would highlight the U.S./West as the aggressive superpower bloc. In fact, these theorists firmly believe that U.S. actions during the final years of Détente were a response to indigenous revolutionary turmoil, and not Soviet actions, in the less developed world. The foreign aid quantitative evidence firmly backs up these predictions. Chapter three demonstrated that American and Western foreign assistance, both military and economic, to the less developed world was much more aggressive than the military and economic aid provided by the Soviet Bloc to the less developed world. The U.S./West was aggressive with their foreign assistance to the Buffer Zone (Afghanistan/Pakistan), the Middle East, and Asia while the Soviets had only significantly increased their foreign assistance to their satellite region of Eastern Europe. Such findings were corroborated with the archival evidence in chapters four and five.

Chapter four, an analysis of U.S. foreign policy archives of the Soviet Union from various U.S. bureaucracies, showed that the Soviets were defensive in the less developed world during the final years of Détente. Chapter five found the reverse for the Americans. The U.S. archives also showed the U.S. being aggressive in Buffer Zone, the Middle East, and Asia.

Secondly, structural Marxists also believe there was a second battle going on between the U.S. and the rest of the Western Bloc. For although both the U.S. and the West worked together to exploit and control the less developed world, as somewhat demonstrated with the foreign aid quantitative evidence in chapter three, the emerging 
decline of the U.S. during the early 1970's was leading to increasing tensions between the U.S. and West. The closer parity (especially economically) between the U.S. and West was causing increasing friction between the U.S., Japan, and Western Europe. I found archival evidence to support this contention in the U.S. bureaucratic foreign policy archives. From Kissinger's remarks about Western European capitulation to the Arabs during the ArabIsraeli and oil embargo conflicts of the early 1970's to the 1979 CIA report entitled "Changing Power Relations among OECD States", which argued that Western Europe and Japan were becoming too independent and engaging in actions that were detrimental to the Western Alliance, there is evidence to support the contention of inter-West conflict causing the U.S. to ratchet up the Cold War hysteria in order to smooth over the tensions with the Western Alliance.

The followers of domestic politics would argue that there is substantial evidence supporting their interpretation of the final years of Détente. U.S. bureaucratic documents from chapter four and five display a significant amount of interagency conflict between the State Department and the more hawkish NSC, Defense, and CIA. For instance, the archives in chapter five showed the NSC and the CIA working in favor of covert actions against the Soviets in Angola and Afghanistan when the State Department, both in chapters four and five, was arguing that the Soviets were trying everything in their power to not involve themselves in those countries. Interagency conflict regarding US policy toward Angola and Afghanistan was epitomized by the bureaucratic maneuvering of both Kissinger and Brzezinski to have their preferred policies adopted by the President.

The Latin American archives of the U.S. in chapter five contained evidence of conflict between the State Department's American Republic Affairs (ARA) and the 
Defense Department in opposition to Secretary of State Vance (and most of the State Department), NSC Advisor Brzezinski, and the Treasury Department. Indeed, the ARA and Defense argued in favor of a "special relationship" with Latin America consisting of helping countries that were the most strategic to the U.S. while Vance and Brzezinski argued in favor of a North-South strategy of pursuing economic liberalism throughout the region. The battle between the hawks and the doves would only intensify by the end of the 1970's with the victory of the Sandinistas in Nicaragua.

Finally, while Asia did not initially witness the same tension that occurred in Afghanistan and Southern Africa, supporters of domestic politics would argue that such tension was only masked by the fact that the State Department and the Defense Department were both able to have their respective interests satisfied. For example, the archives in chapter four and five showed the State Department pushing for the development of ASEAN and U.S. economic interests and Soviet accommodation. On the other hand, the archives in chapter four and five showed the Defense Department pushing for increased funding for the U.S.'s naval and air power. Still, such a push by the Defense Department was couched in its belief (as shown in the archives in chapter four) that the Soviets were becoming aggressive in the region. This was not the view of the State Department.

\section{Structural Marxism versus Domestic Politics}

It is not possible at this time to decide whether structural Marxism or domestic politics best explains U.S. actions during the 1970's. Although I did set out to find out whether one specific alternative theory (should balance of threat have been rejected) best explains the aggressive actions of the U.S., the archival evidence does not fall strongly on one side or the other. Structural Marxists can argue that U.S. hostility in the Middle East, 
Asia, and Eastern Europe was followed through without any significant chasms between U.S. bureaucratic agencies. Moreover, in the case of Latin America, they would argue that the "liberals" did not really pursue the moderate political approaches when they truly had the opportunity. This, however, can be countered by supporters of domestic politics. Significant bureaucratic conflict was detected in Afghanistan and Southern Africa. They would also make the case that there was bureaucratic disagreement in the regions of Latin America and Asia.

To determine, if it is even possible, which of these two alternative theories best explains U.S. actions during the middle-to-late 1970's it would be necessary to engage in further testing. I would advocate for future researchers to explore the specific connections and linkages between U.S. bureaucratic agencies and U.S. corporate and capitalist interests in the less developed world during the 1970's. They should explore whether there was a connection between certain business interests favoring one approach while other business groups were clamoring for another approach. The military industrial complex and all of the business connections they have with certain sectors of the U.S. military should definitely be investigated. Also, I would advocate for researchers to study how much influence Kissinger and Brzezinski truly possessed in setting U.S. policy. Doing this would go a long way in determining whether structural Marxism or domestic politics is a stronger theory.

Of course, many scholars have already explored these questions and have come out in favor of one approach or the other. However, such works are usually either too specific (case studies) or too broad and theoretical in nature. I would advocate for a more focused approach. It should look at region by region, especially the regions each theory has a significant disagreement, in order to determine whether there is an engine to U.S. 
capitalism at the top that pushed the U.S. to seek power and resources in the less developed world or whether there is really no such engine. Is it just as simple as business competing with each other for superiority?

\section{Seeking a Preponderance of Power?}

\section{Section Introduction}

Now that the conventional realist theory has been dismissed, it is time to consider a realist theory that falls more in line with the predictions made by structural Marxists and adherents to bureaucratic politics. Offensive realism is this theory and although it can be considered an ideological cousin of balance of threat realism, the former sharply breaks with latter's contention that aggressive actions on the part of the U.S. against the Soviets and the less developed world would have to be premised by a persistent Soviet challenge against U.S. interests in the less developed world. With respect to structural Marxists and supporters of domestic politics, offensive realism would challenge the notion that the U.S.'s actions and the collapse of Détente stemmed from economic and/or bureaucratic motives. Such theorists would argue that U.S. actions can be explained as an attempt to capture as much military, economic, and political power as possible.

As I mentioned in the first chapter and throughout this dissertation, balance of threat realists proposed that the Soviets were being aggressive in the less developed world during the late 1970's as a result of U.S. military/economic decline. Should there have not been such a newfound vacuum in the balance of power, giving way to new opportunities for the Soviets to make gains in the less developed world, balance of threat realists would have argued that the U.S. would not have been aggressive during the final years of Détente. Balance of threat realism, like most structural realist theories, believes a superpower 
hegemon is usually pleased with a given amount of power. Any continuation of accumulation of power by the hegemon is too risky and too costly of a strategy. War, the strategy often used to attain power, is expensive and there is no reason for a hegemon nation to exhaust its military power engaging in perpetual war when a hegemon can already dominate and control the system through various mechanisms at its disposal. Given that the fact that the evidence suggests that this was not the case, it is important to consider an alternate realist theory that falls more in line with the findings of this dissertation.

After all, adherents of offensive realism would counter that the foreign aid quantitative data and the archival evidence goes against all of the tenets of balance of threat realism. The U.S. did not step back just because it determined that Soviet actions in the less developed world were defensive in nature. Quite the contrary, the U.S. vehemently pushed in favor of its interests in the less developed world. U.S. covert actions in Afghanistan and Southern Africa and its aggressive actions in Asia and the Middle East suggest the U.S. sought to capture as much power (military and economic) as possible. While the immediate goal may have been to reduce Soviet influence in the less developed world or the influence of nationalist/leftist forces, the overriding goal for the U.S., according to offensive realists, was to amass as much power in the international system as possible. John Mearsheimer (2002), the proverbial father of offensive realism, summarized this theory in his book The Tragedy of Great Power Politics. Mearsheimer (2002) argues the following:

Given the difficulty of determining how much power is enough for today and tomorrow, great powers recognize that the best way to ensure their security is to achieve hegemony now, thus eliminating any possibility of a challenge by another great power. Only a misguided state would pass up an opportunity to become hegemon in the system because it thought it already had sufficient power to survive. (p. 35) 
He is basically arguing that it is the uncertainty of the international system that forces states to capture as much power as possible. The U.S. was structurally obliged to push for gains in the less developed world during the 1970's despite the defensive posture of the Soviet Union.

The Imbalance of Power at the Start of the 1970's

The quest of unyielding strategic power throughout the world by the U.S. is chronicled in Perils of Dominance: Imbalance of Power and the Road to War in Vietnam by Gareth Porter. Porter (2006) argues that:

It was not Cold War ideology or exaggerated notions of the threat from communism in Southeast Asia that paved the U.S. road to war in Vietnam but the decisive military dominance of the United States over the Soviet Union. The extremely high level of confidence on the part of national security officials that the United States could assert its power in Vietnam without the risk of either a major war or a military confrontation with another major power conditioned the series of decisions that finally led to war. To put it another way, the imbalance of power so constrained the policies of Moscow and Beijing toward Vietnam (and toward the peripheral countries more generally) that it created incentives for ambitious U.S. objectives in that country. (p. 259)

Therefore, the overwhelming strategic power of the U.S. gave U.S. strategic planners the green light to engage in aggressive actions in Vietnam. There were no checks and balances in the international system as China and the U.S.S.R. could not challenge American military power.

The case for aggressive actions in Vietnam, based on the realization of a preponderant imbalance of military power in favor of the U.S. (sometimes in 1954-1955), begins with Eisenhower's Secretary of State during the 1950's. Surveying the balance of power in Southeast Asia, Porter (2006) argues that:

John Dulles was accumulating evidence that the Soviet leaders had adopted a soft foreign policy because they were particularly concerned over their relative 
disadvantage during the next few years until they have acquired nuclear weapons and delivery capabilities sufficient to counterbalance those of the U.S. (p.102)

Dulles' evidence combined with indications that the "North Vietnamese were effectively constrained by Soviet and Chinese fears of war with the U.S.," caused Dulles to feel that there "was no serious downside to scrapping the elections called for by the Geneva Accords" (Porter, 2006, p. 103). The U.S. would force the hand of the North Vietnamese and engage in aggressive actions against them.

Porter (2006) argues that the same dynamics continued throughout the administrations of Presidents John F. Kennedy and Lyndon Johnson. In the case of the Kennedy administration, Porter (2006) argues the "absence of any external constraint [U.S.S.R., China] led Kennedy's key advisers to advocate the use of U.S. forces in South Vietnam with little or no debate" (p. 260). The same goes for Johnson's administration. U.S. national security officials still believed the U.S. possessed such an asymmetry of power, both over Vietnam and the Communist bloc (China and Russia), that they believed America's might would eventually lead it to victory.

By and large, this appetite for unending power came from the national security bureaucracy. Key national security officials, as the leaders of the organizations that processed foreign policy intelligence and controlled the flow of information to the U.S. president, ultimately possessed "values, attitudes, and interests...that were focused overwhelmingly on U.S. power and [so] the signals of highly unequal power relations had a very direct influence on their policy preferences" (Porter, 2006, p. 259). The incoming presidencies of Eisenhower, Kennedy, and Johnson, according to Porter, never stood a chance against the constant pressure placed on them by the national security bureaucracy. 
Though all of the presidents wanted to avoid war in Vietnam (or go at least go about it in a different way), the unified pressure of the national security bureaucracy and their ability to control the flow of information significantly altered the policy preferences and approaches of the incoming executives.

Porter's Thesis and the Fall of Détente

Porter's hypothesis fits very well with the narrative and the evidence found throughout my dissertation. As in the case of Vietnam, Soviet constraint during Détente did not lead the U.S. to a more moderate foreign policy in the less developed world. Quite the opposite, Soviet constraint actually led to aggressive U.S./Western Bloc foreign policies in the less developed world. The historical/process-tracing findings in chapter three showed that the West was significantly more aggressive than the Soviet Bloc in the less developed world. The same goes for the archival findings. Assertions from U.S. national security officials of Soviet caution during Détente (as in chapter four) only led to a more hawkish tone from U.S. national security officials and a more aggressive foreign policy.

As I go region by region, I found that U.S. foreign policy was aggressive in all of them. The historical/quantitative and archival findings pertaining to Asia did not show the U.S./West losing ground to the Soviets in the region. While the U.S./West may have pulled out of Vietnam, the foreign aid and archival data shows U.S. officials simply opted for a different strategic approach. The West focused on developing and securing ASEAN as a counter-Bloc to the Soviets. The West also used China as a wedge to weaken the Soviets. In sub-Saharan Africa, I found that the Soviets were not truly aggressive with their foreign aid packages. They did not send in the necessary aid to allow the state of Angola to 
consolidate. We also found that the U.S. engaged in highly aggressive covert operations with South Africa.

The data on the Middle East, which was obviously the most important region to the U.S./West, also showed that the West was more aggressive than the Soviets. The West provided significantly more foreign aid to its allies in the region. The U.S. was also engaged in a strategy of trying to expel the Soviets from Egypt which they succeeded in doing.

Latin America, the U.S.'s perennial backyard, is another region where the Soviets were not aggressive. Not only was Soviet aid to Cuba mostly en route to Angola, but the evidence showed the U.S. to have engaged aggressively in the region while the Soviets acted cautiously. Just by comparing U.S. actions in Chile versus Soviet actions in Nicaragua you would see that the U.S. engaged in very aggressive actions in the former while the Soviets engaged treaded very cautiously in the latter.

Finally, the quantitative and archival evidence also showed the U.S. was more aggressive than the Soviets. The U.S./West sent more aid to Pakistan/ Afghanistan than the Soviets. The U.S., knowing that the Soviets did not want to invade Afghanistan, also engaged in covert operations that plunged the Soviets into Afghanistan.

Therefore, it is obvious that Porter's thesis directly connects with the findings in my dissertation. Soviet constraint did not lead the U.S. to a less aggressive foreign policy in the less developed world. Instead, it pushed U.S. officials more and more to capture as much power in the international system as possible.

Porter's findings about U.S. key national security officials pushing for aggression without any significant trace of Soviet belligerence also strikes a connection with my 
findings relating to national security officials. There simply was a precedent for the subsequent actions undertaken by Henry Kissinger and Zbigniew Brzezinski during the rest of the 1970's. The uncompromising thirst for U.S. power never abated. Porter's research finds key national security officials, such as Dulles and McNamara, as vital gatekeepers to the U.S.'s continuing aggression.

The same can be said for Brzezinski in the Carter administration and Kissinger in Nixon's administration. Indeed, my dissertation found President Carter admitting that Brzezinski had immense influence over his foreign policy decisions. There is also evidence that Kissinger intensely lobbied Nixon over U.S. actions during the Arab-Israeli War of 1973.

Offensive Realism Fails as a Strategy

Though offensive realism may be a useful theory in explaining the actions of the U.S. during the Cold War and the final years of Détente, it ultimately leads to a significant amount of failures. Oftentimes, pursuing this aggressive strategy actually leads to negative results for the nation that deploys them. Porter (2006) agrees that this was the case with Vietnam as he writes that:

The tragedy of Dulles's [original] decision (to engage in aggressive actions) is compounded by the fact that Eisenhower had already ruled out U.S. military intervention to save South Vietnam from just the kind of internal Communist insurgency that arose in 1960 in response to the U.S.-instigated repression. (p. 259)

Therefore, aggressive actions on the part of the U.S. in Southeast Asia only increased the

flames of resistance. It did not break the backs of the communists nor lead to victory for the U.S. Porter (2006) continues and adds:

The notion that the ability of the United States to threaten North Vietnam with vast destruction could be used to control Hanoi's role in the war in the South still had a 
strong hold on the thinking of Johnson's advisers in March-April 1965. It was based on a historical reality: the North Vietnamese had constrained their role in the South for years out of fear of U.S. retaliation. Those advisers failed to consider two new realities, however: first, the major escalation of the war in the South —and of American military involvement in it - meant that Hanoi's leaders had reached a threshold where they regarded the failure to send North Vietnamese troops to the South as having potentially irreversible consequences. Thus they were willing to accept some increased risk of U.S. bombing by late 1964 and early 1965 in order to achieve an improved military balance in the South. (p. 263)

Thus, the hyper-aggressive actions on the part of U.S. planners did not result in North Vietnamese acquiescence. The complete opposite occurred. Increased hostility on the part of the U.S. forced the North Vietnamese to lead no stone unturned in their battle for survival against the U.S.

\section{Blowbacks and U.S. Policy}

Quite the contrary, there are many times when hyper-aggressive actions on the part of the U.S. have had a blowback effect. Chalmers Johnson (2004), author of Blowback:

The Costs and Consequences of American Power writes that:

Blowback refers to the unintended consequences of policies that were kept secret from the American people. What the daily press reports as the malign acts of 'terrorists' or 'drug lords' or 'rogue states' or 'illegal arms merchants' often turn out to be blowback from earlier American operations. (p. 8)

According to Johnson (2004) U.S. policy only results in the U.S. "reaping what it sows" (p. 17).The attacks of 9/11 firmly fall in this category. As Johnson (2001) writes: 
We are badly mistaken if we think that we in the United States are entirely blameless for what happened to them. The suicidal assassins of September 11, 2001, did not 'attack America,' as our political leaders and the news media like to maintain; they attacked American foreign policy. Employing the strategy of the weak, they killed innocent bystanders who then became enemies only because they had already become victims. Terrorism by definition strikes-at the innocent in order to draw attention to the sins of the invulnerable. The United States deploys such overwhelming military force globally that for its militarized opponents only an 'asymmetric strategy,' in the jargon of the Pentagon, has any chance of success. When it does succeed as it did spectacularly on September 11, it renders our massive military machine worthless: The terrorists offer it no targets. On the day of the disaster, President George W. Bush told the American people that we were attacked because we are 'a beacon for freedom' and because the attackers were 'evil.' In his address to Congress on September 20, he said, 'This is civilization's fight.' This attempt to define difficult-to-grasp events as only a conflict over abstract values- as a 'clash of civilizations,' in current post-cold war American jargon-is not only disingenuous but also a way of evading responsibility for the 'blowback' that: America's imperial projects have generated. (para. 2)

The original arming of these Islamic terrorists against the Soviets in the late 1970's/ early 1980's is another example of how aggressive actions on the part of the U.S. begin the cycle of blowbacks. Arming Islamic terrorists against the Soviets only came back to boomerang the U.S several decades later in the form of the Taliban. Interestingly enough, the U.S. policies of supporting the Saudi Arabian and Egyptian dictatorships throughout the Cold War are what spawned Islamic terrorism in the first place. Blowbacks are often preceded by blowbacks.

Connecting the Johnson thesis with my findings leads me to believe that continuous U.S. hyper-aggression contributed to an increase in the revolutions and revolutionary turmoil during the 1970's. From the indigenous peoples of Latin America to the shantytowns of Southern Africa, it is obvious that U.S./Western political and economic repression has led many in the less developed world to rise up and support communist and nationalist insurgencies. U.S. support for dictatorships in Latin America and apartheid in 
Southern Africa only fanned the flames of revolution. Blowback, after all, does not just come from the damage inflicted by drug lords and terrorists. It also comes, as Porter shows with the case of Vietnam, from guerrillas and communist insurgents.

As I move forward from the Détente time period it is obvious that U.S. blowbacks continue. Apart from 9/11, there have been other instances of blowbacks that currently afflict the U.S. For instance, forced to introduce "democracy" in Latin America due to the rise of nationalist insurgencies, past U.S. repression and aggressive policies has led to large-scale anti-Americanism in the region. From Venezuela and Bolivia to Argentina and Brazil, it is obvious that leftist resistance has somewhat weakened the U.S.'s hold in the region. Another example is the case of Iraq. The invasion of this country has only allowed Iran's strategic power to increase. The result of this rise is increased tension between Israel, the U.S.'s major proxy in the Middle East, and Iran. This is because Israel now views Iran as its major competitor in the region. Critics would argue that the U.S. should not have used aggression against Iraq as it only served to significantly weaken Iran's mortal enemy. Iran was no longer contained.

Offensive realists would argue that 9/11 was only the collateral damage. Despite the fact that U.S. hyper-aggression resulted in an attack on homeland soil, they would argue that the aggressive approach will allow the U.S. to eventually dominate the Middle East. Invading Iraq (and possibly overthrowing Iran) and using repressive regimes (such as Saudi Arabia and Egypt) to control the region will result in the U.S. remaining the most dominant nation in the world. Of course, terrorists will strike. September 11 was simply the collateral damage and the price Americans must may for empire. 
I would counter that hyper-aggressive U.S. action in the international system is not a sign of strength on the part of the U.S. but a sign of weakness. Indeed, Johnson (2004) cites David Calleo as stating that, "the international system breaks down not only because unbalanced and aggressive new powers seek to dominate their neighbors, but also because declining powers, rather than adjusting and accommodating, try to cement their slipping preeminence into an exploitative hegemony" (p. 222).

Johnson (2004) continues and writes:

I believe that the United States at the end of the twentieth century fits this description. ... one must conclude that blowback will ultimately produce a crisis that suddenly, wrenchingly impairs or ends America's hegemonic influence... barring an unforeseen reform movement, it seems most probable that economic contradictions will force the unraveling of the American empire. (p. 222)

America, in my view, is a declining power. There are signs from the past that point in this direction. As highlighted in the introductory chapter of this dissertation, structural Marxists have shown that superpowers on the decline have a historical tendency to become more militant. I agree with this view. Rather than seek accommodation, studies of the Kondratieff cycle have shown that the core state within the core becomes very hostile towards the less developed world once it realizes that its grip on the international system is not what it once was. Thus, it responds with militancy. However, this militancy is ultimately not successful. It fails because its decline, closely related with the cycles of financial and productive capitalism, is pretty much set in stone.

There are signs all around showing that this is occurring. The rise of China is, of course, the most obvious signal. After all, how else can one explain the fact that the U.S. does nothing about its economic policy towards China (which causes economic problems 
in the U.S. and will result in China becoming a superpower down the road) while it goes ahead and fights insignificant enemies in the Middle East?

Finally, should offensive realism guide the strategic thinking of U.S. policymakers, it is probably time for national security officials to discard hyper-aggression as a strategy. The costs are too high. The burden of policing the world is starting to catch up with the U.S. Policymakers in the U.S. need to let go of their desire to control the policies of countries throughout the less developed world. The U.S. was allowed to chart its own path. It gained its independence from England and was, for the most part, free to pursue the economic policies it wished to pursue. Policymakers in the U.S. need to let go so that we may truly build a true integrated, prosperous, and nonviolent world older.

Supporting Structural Marxism

In the end, I personally agree with the theory of structural Marxism. There are several reasons why I do. First of all, offensive realism's claim that alliances do not last in the long run because states can not trust each other does not hold in my view. Quite the contrary, the Western Alliance has not fractured. Rather than seek total dominance in the international system, the U.S. glued together Japan and Western Europe with the rest of the world economy. Significant friction within the Western Alliance has not developed. In fact, when faced with the possibility of friction in the Western Alliance, U.S. documents show the U.S. doing everything in their power to stop it. Yes, there have been frictions within the West (Iraq). However, the type of conflicts predicted by realists after the Cold War has not held sway. The economic institutions and frameworks set up by the Western Alliance have continued to dominate the international relations system. 
I also believe that the economics behind the linkages within the Western Alliance are also very significant in explaining the past and predicting the future. It is imperative to study economic power in order to truly appreciate the evolving nature of the international system. There are other important agents in the international arena. From transnational corporations (structural Marxists) to belligerent agencies in the government that are tied together with certain business interests (domestic politics), there definitely are other important components of the international system. By bringing in these important structural aspects of the world economy, I believe structural Marxists can better explain the transformation and transformative potential of the international system.

From the early Italian city-states, to the Netherlands, to England, and then to the United States (and eventually to China), the way in which structural Marxists can horizontally connect (through economics) the dynamics behind the evolvement of the world economic system is simply unmatched. How else can one explain the huge outflows of capital that left the Netherlands in favor of England? How else can one explain the rise of China, India, and Brazil? For sure, no one can argue that China's rise has been as a result of its military power!

The cycles of militant hyper-aggression and blowbacks, while U.S. economic policy allows China and India to continue to ascend, invariably reduces the legitimacy, in my view, of offensive realism in favor of structural Marxism. U.S. foreign policy has not served the interests of the U.S. Perhaps this is because U.S. national security officials are not really realists, but members of a U.S. economic transitional elite class whose interests are more class-based than state-based. 


\section{REFERENCES}

Johnson, C. (2001). "Blowback." The Nation Magazine. October 15, 2001. Retrieved December 29, 2008 from

http://www.thirdworldtraveler.com/Sept_11_2001/Blowback_CJ_article.html.

Johnson, C. (2004). Blowback: The Costs and Consequences of American Empire

Mearsheimer, J. J. (2002). The Tragedy of Great Power Politics, W. W. Norton: New York

Porter, G. (2006). Perils of Dominance: Imbalance of Power and the Road to War in Vietnam, University of California Press: Berkeley 
VITA

\section{DOUGLAS RIVERO}

September 7, 1979

Born, Havana, Cuba

B.A., Environmental Studies

Florida International University

Miami, Florida

2003-2007

Delores Auzzenne Graduate Student Fellowship

2005

M.A., Political Science

Florida International University

Miami, Florida

2005

Pi Sigma Alpha, National Political Science Honor Society

2009

Doctoral Candidate in Political Science

Florida International University

Miami, Florida

\section{PRESENTATIONS}

International Studies Association, March 2007, Paper Entitled: Soviet and Western Bloc Competition in the Less Developed World

Southern Political Science Association, January 2005, Paper Entitled: Electoral Systems and Environmental Policies 